Andrzej Kątny / Izabela Olszewska /

Aleksandra Twardowska (eds.)

\title{
Ashkenazim \\ and Sephardim: \\ Language Miscellanea
}


SPRACH - UND KULTURKONTAKTE

IN EUROPAS MITTE.

STUDIEN ZUR SLAWISTIK

UND GERMANISTIK 7

\section{Andrzej Kątny / Izabela Olszewska /}

Aleksandra Twardowska (eds.)

\section{Ashkenazim and Sephardim: Language Miscellanea}

The collection of articles chosen by the editors presents a broad variety of issues connected with Jewish languages (Judeo-Spanish, Yiddish) and co-territorial languages used by Ashkenazi and Sephardic Jews in different places and periods. Thus, the book contains both strictly linguistic and sociolinguistic descriptions (including the aspects of evaluating language, language in contact or linguistic identity), the presentation of languages in literary works (and their translations) from different periods, as well as lexicographical and cultural observations. This thematic variety shows opportunities for the research into the languages of both Jewish groups and inspires other scientific projects in this field.

\section{The Editors}

Andrzej Kątny is Professor of German linguistics at the University of Gdarísk (Poland). His research interests include German linguistics, Polish-German contrastive studies, and contact linguistics.

Izabela Olszewska is Assistant Professor at the Institute of German Philology at the University in Gdańsk (Poland). Her academic interests involve the language and culture of Ashkenazi Jews, Holocaust, media linguistics, and culture of remembrance.

Aleksandra Twardowska is Assistant Professor at the Department of Balkan Studies at the Nicolaus Copernicus University in Torun (Poland). Her academic interests involve the language, culture and history of Balkan Jews, Jewish and Slavic anthroponomy, and Balkan languages. 
Ashkenazim and Sephardim: Language Miscellanea 


\section{SPRACH- UND KULTURKONTAKTE IN EUROPAS MITTE STUDIEN ZUR SLAWISTIK UND GERMANISTIK}

Herausgegeben von

Andrzej Kątny und Stefan Michael Newerkla

Band 7 
Andrzej Kątny / Izabela Olszewska /

Aleksandra Twardowska (eds.)

\section{Ashkenazim and Sephardim: Language Miscellanea}

\section{量


Bibliographic Information published by the Deutsche Nationalbibliothek The Deutsche Nationalbibliothek lists this publication in the Deutsche Nationalbibliografie; detailed bibliographic data is available online at http://dnb.d-nb.de.

\section{Library of Congress Cataloging-in-Publication Data}

A CIP catalog record for this book has been applied for at the Library of Congress.

Reviewed by Monika Adamczyk-Garbowska, Michail L. Kotin, David Malcolm, Ivana Vučina Simović, Krinka Vidaković-Petrov

Published with financial support from the University of Gdańsk (Institute of German, J.G. Herder Foundation) and the Nicolaus Copernicus University in Torun (Departemnt of Balkan Studies, Faculty of Languages)

ISSN $2192-7170$

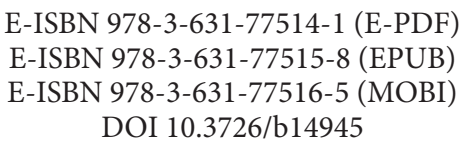

DOI $10.3726 / \mathrm{b} 14945$

\section{PETER LANG
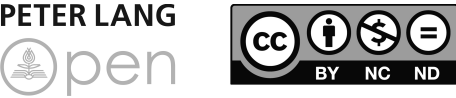

Open Access: This work is licensed under a Creative Commons Attribution Non Commercial No Derivatives 4.0 unported

license. To view a copy of this license, visit https://creativecommons.org/licenses/by-nc-nd/4.0/

(C) Andrzej Kątny / Izabela Olszewska / Aleksandra Twardowska (eds.), 2019

Peter Lang - Berlin · Bern · Bruxelles ·

New York · Oxford · Warszawa $\cdot$ Wien

This publication has been peer reviewed.

www.peterlang.com 


\section{Preface}

The second multiauthor volume which presents the state of research on the Ashkenazi and Sephardic Diaspora ${ }^{1}$ covers the issues concerning the languages used by Ashkenazi and Sephardic Jews: Yiddish, Judeo-Spanish (Ladino) and others.

The volume begins with a text by the independent researcher Julie Scolnik (San Francisco), which is the only one describing the situation of Jewish groups following the emigration from Europe (in this case both groups, but mainly the Sephardic group). The author characterizes Jewish immigrants in the United States at the turn of the 19th and the 20th centuries from a sociolinguistic perspective. She concentrates, however, on the phase of acquiring a new language - English. Scolnik also lists problems connected with the integration of this minority with American society. The article contains detailed information about the cultural activity of the Sephardic emigration, as well as the characterization of sociocultural institutions and organizations, and of specific people who acted in support of the emigrants' assimilation. The author, however, gives special attention to the acquisition of the English language (and in the case of the Sephardic Diaspora also of the Yiddish language) in the process of Jewish emigrants' assimilation: she characterizes schools, teachers and methods of teaching the language.

Izabela Olszewska (Gdańsk) and Aleksandra Twardowska (Toruń) reflect in their paper on An Image of Yiddish and Judeo-Spanish in the Jewish Press of the First Half of the Twentieth Century. The authors analyze the press discourse (in the Jewish German-language and bilingual Judeo-Spanish/Serbo-Croatian press of a sociocultural type) in relation to the positive evaluation of both Diaspora languages and their important role in the Jewish culture and tradition. In this respect, the article discusses various issues, for example attempts to describe Yiddish from a linguistic, ethnological and anthropological perspective as well as Yiddish-language press and literature. Analogous topics concerning JudeoSpanish appeared in the Jewish press in Bosnia along with the descriptions of organizations and sociocultural events connected with the Judeo-Spanish tradition or with diverse Ladino texts.

1 The first multiauthor monograph in this series Ashkenazim and Sephardim: A European Perspective edited by Andrzej Kątny, Izabela Olszewska and Aleksandra Twardowska was published in 2013. 
Language analyzed as the determinant of Jewish identity (and identity as such) is the subject matter of the text by Jonny Rock (Berlin). The author bases her reflections on the interviews with members of the contemporary Jewish community (of different generations) in Sarajevo. The author states that the Sephardim of Sarajevo have long reflected the complex relationship between language, religion and an ethnic background. Therefore, the analysis of their contemporary linguistic situation in Bosnia and Herzegovina, in which three variations of one regional language, replaceable in communication, have transformed into three distinct standards (Bosnian, Croatian and Serbian), seems to be particularly justified. By means of the conducted interviews, the author tries to determine how the Jewish-Sephardic linguistic identity in Sarajevo was shaped from the perspective of historical events, e.g. the fall of Yugoslavia. The article also characterizes the social background of the Jews from 1945 to 1992, as well as the present status of the Jews in Sarajevo.

In their paper Aitor Gracía Moreno (Madrid) and Dora Mancheva (Geneva) combine lexicographical observations about the Judeo-Spanish language with reflections of a cultural kind analyzing three types of sources (dictionaries, lexicons and one magazine) which were published in print in Bulgaria at the beginning of the 20th century. The corpus collected by the authors refers to cookery and their analysis of semantic domains connected with food (vegetables, meat, fish, etc.), drinks, the prices of products, units of measurement and culinary customs includes numerous comparisons of the collected lexemes and the reflections on their origin. Great value of this text lies in a testimony to the linguistic situation, customs and culture of the Bulgarian Sephardic Jews in a multi-ethnic environment. These reflections are complemented by the introduction outlining the history and situation of Bulgarian Sephardic communities at that time.

The text by Agnieszka August-Zarębska and Tomasz Zarębski (Wrocław) is a means of reflecting on the Judeo-Spanish language in the area of the contemporary Israeli poetry using the example of Margalit Matitiahu's volumes. The key to analyzing Matitiahu's work is the motif of oikos which the authors of the article explain giving a few definitions used in literary and cultural studies. In the case of the analyzed poetry the motif of oikos is also supposed to include language. According to the authors, Ladino, although it is not Matitiahu's first language, was not chosen by accident. It is supposed to symbolize the culture of the poet's Sephardic ancestors considered at the two levels of history and tradition: Sephardic communities of the Balkans, that is of Thessaloniki (where Matitiahu's parents came from), and the mythical Sefarad - the Iberian cradle of past ancestors' culture. 
It is also Katja Šmid (Madrid) who makes a reference to the Ladino language in literature. She focuses, however, on the description of Judeo-Spanish translations of the Hebrew publication Sefer ha-Berit [The Book of Covenant] which is of an encyclopedic and educational nature. The Hebrew original, first published in the late 18th century, gained such popularity that there quickly appeared the need to translate the text (or its excerpts) and to make it familiar to the readers from the Sephardic Diaspora. The author points at the differences between the original and its translations with respect to the structure and content, portrays the origin of changes made by translators and sometimes refers to their dialogue and disputes with an author of the original text.

Katsenelson's elegy Dos lid fun oysgehargetn yidishn folk is one of the most important literary testimonies of annihilation. The article by Magdalena Sitarz and Andrzej Pawelec (Krakow) analyses the story of how the manuscript was created and of its different editions. This epic poem comprising 15 lamentation songs (cantos) was written when Katsenelson was imprisoned in a German internment camp in Vittel (France). The authors outline the poet's biography and illustrate how the poem was created, the events surrounding the manuscript and its different editions. The poem was also published in translations, including English, Hebrew, Polish and German.

The volume concludes with an extensive article by the Slavic philologist Sandra Birzer (Innsbruck) concerning strictly linguistic issues; the author studies a subjective resultative construction with an adverbial participle in Yiddish and in co-territorial languages, i.e. in Russian and Polish. While this structure is well researched in these two Slavic languages, there are no analyses referring to Yiddish. The analysis is based on the examples from language corpora (e.g. The Corpus of Modern Yiddish, The Russian National Corpus); it aims at specifying differences and similarities between Yiddish and the mentioned languages in relation to the use of resultative constructions. The empirical analysis concerning, for example, the functional distribution of participles proved, among other things, a high level of similarity between Polish and Yiddish. The author suggests that this results from a long-term face-to-face linguistic contact. As an $\mathrm{H}$-language Russian in the Russian empire was not used in everyday contact with Yiddish speakers.

The collection of articles chosen by the editors presents a broad variety of issues connected with Jewish languages (Judeo-Spanish, Yiddish) and co-territorial languages used by Ashkenazi and Sephardic Jews in different places and periods. Thus, the volume contains both strictly linguistic and sociolinguistic descriptions (including the aspects of evaluating language, language in contact or linguistic identity), the presentation of languages in literary works (and 
their translations) from different periods, as well as lexicographical and cultural observations. The editors believe that this thematic variety shows opportunities for the research into the languages of both Jewish groups and inspires other scientific projects in this field.

Andrzej Kątny / Izabela Olszewska / Aleksandra Twardowska 


\section{Contents}

\section{Julie Scolnik}

Yiddish and Judeo-Spanish Speakers and the Acquisition of English in Immigrant America During the Late 19th and Early 20th Centuries

Izabela Olszewska and Aleksandra Twardowska

A Positive Image of Yiddish and Judeo-Spanish in the Jewish Press of the First Half of the 20th Century: An Overview

Jonna Rock

Sarajevo Sephardim and Their Linguistic Identification

Aitor García Moreno and Dora Mancheva

Eating and Drinking among Bulgarian Sephardim at the Turn of the 20th Century

Agnieszka August-Zarębska and Tomasz Zarębski

Language as Oikos: The Case of Margalit Matitiahu's Poetry

Katja Šmid

Sefer ha-Berit in Ladino: Adaptations and Translations of a Hebrew

Best-Seller for the Sephardi Reading Public

Magdalena Sitarz and Andrzej Pawelec

Yitskhok Katsenelson's Dos lid fun oysgehargetn yidishn folk: A Story of the Manuscripts and Editions

\section{Sandra Birzer}

The Yiddish Subjective Resultative Construction Based on the Adverbial Participle: Convergences and Divergences with Co-Territorial Languages

Notes on the Authors 

Julie Scolnik

\title{
Yiddish and Judeo-Spanish Speakers and the Acquisition of English in Immigrant America During the Late 19th and Early 20th Centuries
}

\begin{abstract}
Fleeing from religious persecution, political repression and restricted economic opportunity in their home countries, both the Ashkenazim and the Sephardim emigrated to the United States at the end of the nineteenth and beginning of the twentieth centuries in search of a better life, The Sephardim arrived slightly later than the Ashkenazim and were not only the minority in terms of number but they were also at the rear in terms of education and language assimilation. Thus, their integration into American society was more difficult. They were faced with the necessity to learn two different languages in order to find their way in their new country: Yiddish and English. This article aims at examining the means, both formal and informal, that existed for both groups, but primarily the Sephardim, to learn English.
\end{abstract}

Keywords: Immigration, Sephardim, Ashkenazim, Yiddish, Judeo-Spanish, English, Language Shift, Language Acquisition, Assimilation, United States of America

\section{Introduction}

During the hundreds of years that the Sephardim lived in the countries of the Ottoman Empire, they enjoyed the freedom to maintain their own religion, language, and customs, they were not obliged to learn Turkish, the language of the land but continued to speak Judeo-Spanish. Another privilege they enjoyed was being exempt from serving in the Empire's armed forces although they were taxed in lieu of this service. However, after the Young Turks Revolution in 1908 compulsory military service was instituted and Jews were now included in the military draft. Confronted with this dire situation and seeking better economic conditions many of them chose to emigrate, mainly to America. Once in America they settled in the Lower East Side of Manhattan (Rivington, Orchard, Chrystie, Ludlow, Allen, Forsythe and Delancey Streets) where the dominant language was English or Yiddish, and many of them worked in factories with Yiddish-speaking managers, owners and employees (Angel 1982: 109). Thus, the need to learn Yiddish may very well have prevailed over that to learn English, especially considering the numerical difference between these two Jewish communities highlighted by Joseph Papo (1987: 43) in Sephardim in Twentieth Century America: 


\begin{abstract}
"The migration to America of some 30,000 Sephardi Jews coincided with the largest and most important migration in all of modern Jewish history, that of roughly two million Ashkenazi Jews, mostly from Russia, who came to these shores from 1881 to 1924. Like their Yiddish-speaking co-religionists, the overwhelming majority of the Sephardi immigrants lived in over-crowded tenements in New York's Lower East Side, perhaps the most densely settled area on earth in the first decade of the century."
\end{abstract}

Irving Howe (1976: 26) describes the migration of one third of the east European Jews in the thirty-three years between the assassination of Alexander II and the outbreak of the First World War as comparable in modern Jewish history only to the flight from the Spanish Inquisition.

Papo (1987: 43) goes on to give an example of the well-known fact that the Ashkenazim found the mode of life of the Sephardim from the Ottoman Empire so alien to their own that they often failed to recognize them as fellow Jews. Such a failure of recognition took place when a group of Ashkenazi residents on the Lower East Side petitioned the Mayor to remove the 'Turks in our midst' because of the disturbance they were creating. When the residents learned that the 'Turks' were in reality Sephardi Jews, they withdrew the petition. Leaders of both groups became increasingly aware of this lack of understanding and began to look for ways to bring about a rapprochement.

Additionally, Papo (1987: 44-45) informs us that on the Sephardic side, Moise Gadol wrote in La America a series of articles in Yiddish entitled Tzou dem Yiddishen Volk [To the Yiddish People] in which he explained the way of life of the Sephardim in Turkey [...] The Yiddish press published a series of interpretative articles on the Sephardi newcomers and appealed to the general community to help the Sephardim achieve a more satisfactory economic and cultural adjustment.

\title{
2 The Role of Jewish Institutions and Individuals
}

The section on immigration included in the book published by Mois Gadol, Libro para embeźar las linguas ingleśa y yudiš [A Book for Learning English and Yiddish] assures the Sephardic immigrants that as soon as they arrive in America, the land of freedom, they will find many Jewish institutions to help them. ${ }^{1}$ Aviva Ben-Hur, however, describes a more realistic picture of these Jewish organizations:

"In both their infrastructure and self-conception Jewish organizations in the United

States were tacitly established to accommodate not Jewish immigrants but rather, Eastern

1 For more information, see (Scolnik 2014). 
European Ashkenazic immigrants. [...] Yes, Sephardi and Mizrahi Jews were indeed fellow Jews. But they did not possess the cultural and linguistic characteristics associated with Ashkenazic Jewry. Moreover, the cultural and linguistic attributes that made them distinctive ('Spanish', 'Arabic' and 'Greek' heritage) marked them in the minds of decisive Ashkenazic leaders more as gentiles than as Jews." (Ben-Hur 2009: 124-125)

Although there is much truth in Ben-Hur's words, the oldest Jewish congregation in existence in the United States is Sephardic: Congregation Shearith Israel. It was established in 1654 with the arrival in New York of twenty-three refugees from Recife Brazil, Sephardic Jews whose ancestors were originally from Amsterdam, and it was to remain the only Jewish congregation until 1825. These refugees were the first Jews to arrive in what would become the United States. Thus, the Sephardim actually preceded the mass immigration of Ashkenazim and Sephardim of the late 19th and early 20th centuries.

As the Jewish community rapidly grew during the late 19th and early 20th centuries, Shearith Israel and its members were involved in important communal enterprises. The Sisterhood operated Settlement houses on the Lower East Side to provide for the needs of the newly arriving Sephardic immigrants, which mainly consisted in social and charitable works. According to a letter I received from Marc Angel they also taught English. ${ }^{2}$

However, there exists a noteworthy person associated with Congregation Shearith Israel who did contribute to English acquisition and that is Rabbi Dr. David del Sola Pool who in 1907 was invited to become the rabbi of the Congregation, also known as the Spanish and Portuguese Synagogue, and where he served as such for 63 years. In 1928 he founded the Union of Sephardic Congregations, under whose auspices he prepared and published a Sephardic prayer book which he translated into English.

Before going on to mention the existing Jewish organizations and specifically those that contributed to English acquisition, two other individuals should be mentioned. The first is Albert J. Amateau who was born in Milas in Turkey in 1889

2 I have not been able to find any documents which describe such classes. I have contacted the American Jewish Historical Society (henceforth AJHS), which holds the records of Congregation Shearith Israel, undated 1755-1996 collection number 1-4 and I was able to consult these extensive records online, discovering that Box 5, Folder 20 contained information on the "consecration of Neighborhood House and pamphlet describing activities of the settlement house 1913 and 1918-1919", and Box 6 Folder 23 contained "Educational Programs". However, there was nothing about English classes in either of these boxes. I would like to thank Boni J. Koelliker, the archivist of the AJHS, for her support. 
and died in 1996 in the USA at the age of 106. Amateau was such an important figure that the American Jewish Archives hold an entire collection in his name, the Albert J. Amateau Collection. His papers were donated in 1996 and include among other documents a 122-page interview conducted with him by Rachel Amado Bortnick in 1989 entitled The Americanization of a Sephardic Turk. In this unpublished interview Amateau does not explain how he learned English as an immigrant in the United States for he had learned English at the American College in Izmir and attended Law School in Istanbul. No sooner had he disembarked on Ellis Island in 1909 when he came to the rescue of a Greek Jewish family by translating for them. This interview is rich in information about Amateau and the Americanization of Sephardic immigrants. One of the things the interviewer asks him to describe is what a settlement house is like, to which he replies:

"Like a big club, like a YMCA. They were constructed in the East Side, in the quarters where there were mostly immigrants, to try to Americanize them [...] The universities operated them. They had a director, social workers, doctors, lawyers, everything [...] gradually they established evening classes to teach English." (Bortnick 1989: 64-66)

Mark Angel tells us more about Amateau's role in English acquisition:

"Amateau visited the Sephardic coffeehouses on Chrystie Street frequented by young Sephardim. He spoke to them about the importance of education but his advice went unheeded. [...] He began an English class in a small dark room at the back of a candy store, which was attended by 20 young people”. (Angel 1982: 25)

In his own words Amateau says: "The malady [of the Sephardim] was ignorance and it was against this that I directed my attack." (Angel 1982: 211)

And we must not forget the important role played by Mois Gadol, founder and editor of La América who stressed the importance of learning English in his newspaper by printing English lessons at the bottom of the pages which could be cut out and saved. Matza (1997: 167) informs us that these pages contained conversation. He quotes Stephen Levy, an avid reader of La América as saying that: "Intermittently during 1911 and 1912 the paper [...] printed conversations composed in a simple, though not altogether flawless English." La América also included in its pages advertisements for language schools where English was taught and what was more important the publication of the aforementioned Libro para embeźar las linguas ingleśa y yudiš in 1916.

\section{English Classes: Teachers and Schools}

As we have said earlier, many Jewish organizations existed: the Hebrew Immigrant Aid Society which was founded in New York City in 1881 and whose 
aim was mainly to help immigrants arriving at Ellis Island who might otherwise be turned away; The Educational Alliance, founded in 1889; The Baron de Hirsch Fund, established in 1891 by Baron Maurice Hirsch to set up charitable foundations to promote Jewish education; The National Council of Jewish Women founded by Hannah Solomon of Chicago in 1893 as a volunteer organization; the Young Men's Hebrew Association (henceforth YMHA) established in Baltimore in 1854; and the Young Women's Hebrew Association (henceforth YWHA) set up as an annex in New York, 1888 etc.

The AJHS holds the records of the Baron de Hirsch Fund, including a manuscript entitled English Classes, n.d. 1890-1900, 1913-1914, which consists of 50 partially handwritten and partially typewritten pages concerning English classes offered by both the Baron de Hirsch Fund and the Educational Alliance. Although these classes were given in Yiddish and directed mainly to Russian Jews, this manuscript has provided information of interest.

It begins with a six-page handwritten letter addressed in New York, July 1, 1890 to The Committee on General Education, Baron de Hirsch Fund and is signed by the Chairman of the Downtown Branch Committee YMHA. Addressing the issue of how many teachers would be needed and what their salary would be it expresses the need:

"to teach English to the immigrants attending industrial classes... to begin the experiment of introducing English instruction in the 'cheders'... where neither teachers nor pupils are able to speak or read English, the language employed in translation being what is known as 'jargon', the permission to use three hours daily to teach English, reading and writing...Further it is deemed desirable to open an adult class of the teachers of the Talmud Torah school and kindred Hebrew schools where teachers impart instruction at these schools in the jargon alluded to..." (English Classes... manuscript)

There follows a typewritten letter dated August 29, 1890 addressed to the Committee on General Education informing of the creation of:

"[...] At No. 1 Canal Street, four classes holding five sessions a week of two hours each under four teachers and at No. 200 East Broadway four classes for adults under two teachers, each class having five sessions a week of two hours in the forenoon, and also one class for adults four days in the week for two hours in the afternoon, and five classes for children holding five sessions a week for three hours a day in the forenoon, making in all fourteen classes [...]." (English Classes... manuscript)

Lastly, a program of entertainment of the Children of the Baron Hirsch English Schools at The Educational Alliance, Tuesday, February 22, 1898 consisting of songs, recitations, a prayer, the presentation and acceptance of the American flag and the singing of the Star-Spangled Banner, the U.S. national anthem. It 
can be seen from this program that Americanization accompanied the learning of English.

In 1913 The Educational Alliance took over the handling of English classes under four headings: 1) Classes in English for adult immigrants, 2) Lectures in Yiddish and English for adult immigrants 3) Classes in citizenship and 4) Citizenship quiz classes. A letter addressed to the Baron Hirsh Fund describes the classes in English:

"These classes are formed for the benefit of those immigrants who are employed at night. Sessions are held daily from 9 a.m. to $12 \mathrm{n}$ [oon]. and from 1 p.m. to 3 p.m. The pupils are divided into four groups or four classes and are graded, as far as possible, in accordance with their knowledge of English. The subjects of study are grammar, reading, geography and history. Conversation is the main part of the lessons." (English Classes... manuscript)

The author then analyses the 249 pupils as to nationalities, sex and age (ranging from 16 to 30). Of particular importance is the breakdown of nationalities: from Russia: 203, Austria-Hungary, 15, Turkey, 27 and Germany, 1. The Turkish students are undoubtedly Sephardim, which is our first confirmation that although aimed at the Yiddish speaking Russian Jewish community, these English classes were also attended by the Sephardim. According to this letter, lectures in English were also offered with the view of acquainting the immigrant with American history, institutions, citizenship, etc.

In addition to formal classes there exists another means of English acquisition: that of the use of a library. An article published by The New York Times in 1996 describes the founding in 1886 of the Aguilar Free Library Society, which later became a part of the New York Public Library, and which has a direct Sephardic connection:

"Until the late 19th century New York had no municipally sponsored public circulating libraries. But in 1886 a new state law offered support to any charitable library with at least $\$ 20,000$ in real estate and more than 10,000 volumes. To meet that threshold, two Jewish organizations, the YMHA and the Hebrew Free School merged their small holdings and that year established [for new immigrants] the Aguilar Free Library, named after Grace Aguilar (1816-1847), an English writer of Sephardic Jewish descent, considered a pioneer in Jewish literature." (Grey 1996)

Addressing the topic of English education in schools, both Jewish schools and public schools, Lloyd Gartner describes the different Jewish schools organized by the Kehillah (Jewish Community) in New York City and the English teachers they employed. According to his account, there were six different agencies which afforded Jewish education to the children of this city: a) Talmud Torah 
Schools, b) Institutional Schools c) Congregational Schools d) Sunday Schools e) Chedorim f) Private tutors. He then goes on to describe the English teachers in Talmud Torah schools:

"The teachers are either immigrants who have acquired a fair amount of English, though not enough to enable them to use it flexibly and to adapt it to the needs of the children: or young men preparing for some profession, who teach, in order to be able to make their way through college... In either case, the teaching is found to be very poor, even though most of the instruction is carried on in English...Seldom, if ever, are any English textbooks made use of; homework is never allotted; the discipline is poor; the attendance is very irregular, and seldom kept up for any length of time. This last is due to the fact that the Jewish population of the poor is constantly shifting from place to place." (Gartner 1969: 119-120)

On the other hand, with regard to Congregational schools, he finds that the teachers are usually young American men and a few women who possess a fair knowledge of things Jewish and that instruction is carried out in English with English textbooks also being used for History and Religion (1969: 122)

Hasia R. Diner (2004: 148-149) discusses the founding of Jewish schools of a particular ideology and highlights the creation in 1892 of the Arbeiter Ring or Workman's Circle by Eastern European Jewish socialist immigrants which, since part of its ideology focused on the power of Yiddish as the tongue of the masses to transmit ideological ideas, from the beginning maintained an educational orientation. By 1918 the Arbeiter Ring launched a network of Yiddish schools for children.

Many children of Jewish immigrants at the break of the 20th century did not go to school but instead worked to help the family economy. According to Diner (2004: 145):

"Immigrants arriving later in the nineteenth century had a different set of options than those who came earlier $[\ldots]$ the earlier era had emphasized work and experience rather than formal learning as the mechanisms of achievement [...] The newly arriving immigrants attended public schools $[\ldots]$ these schools offered the best chance for children to receive an education, at least as long as the children did not have to seek employment. While many Jews, even into the twentieth century needed their children's income to survive, by and large most children went to school."

Legislation in New York and elsewhere both compelled school attendance until the age of sixteen and provided public instruction to all at no charge. In 1910 New York City established classes for immigrants. In Going to America, Going to School: The Jewish Immigrant Public School Encounter in Turn-of-thecentury New York City Stephan Brumberg (1986: 2) supplies extensive information regarding the role of the public school and English acquisition and Americanization: 
"Night schools, lectures, settlement houses, newspapers, street corner orators, libraries, union classes, the workplace, the city streets themselves became sources of knowledge regarding America. But for the children of immigrants one institution towered above all others as the source of American knowledge and lifeways - the public school."

Brumberg (1986: 219) goes on to say that learning English was at the core of all studies:

"Public school education was saturated with reading English, memorizing and reciting English prose and poetry, participating in plays and assemblies, arguing in debates, writing stories and essays, reading the English classics, improving one's diction [...]."

A direct testimony regarding the learning of English in public schools was given to me by Isaac Azose (born Yitshak Azouz) whose father, Yaakov Azouz emigrated to Seattle from Turkey in 1920 and attended the public school in Seattle called Pacific School. Azose recalls his father saying:

"He mentioned specifically that there were Orientals in his class, such as Japanese and Chinese. The Sephardic community used to call them 'Japones i Kinezos'. I specifically remember his telling me that English was a crazy language. He gave me an example of the word 'business' which he pronounced 'ba si ness' and couldn't figure out how it could be pronounced 'biziness."'3

A student's poetic description of attending English classes at night can be found in Bring Me More Stories: Tales of the Sephardim, one of the two books Sally Benforado wrote about her mother-in-law, Mathilde's, experiences as a Sephardic immigrant. This chapter is called "Symphony 1912", 1912 no doubt being the year she attended this school:

"As she walked down the long hallway, she could hear the sounds of many languages spoken by other students at the night school, and her ears liked the sounds. She was reminded of musical instruments tuning for a concert. [...] 'Tonight' said the English teacher, 'I would like to have us begin to use the English language in order to help us get acquainted with one another. Would anyone volunteer?' [...] Mathilde puzzled for a moment over the meaning of 'volunteer' [...] raised her hand [...] 'I come from Smyrna' And she listened to the words as they came from her lips [... It was beautiful [...] But the faces before her looked blank, so she added [...] 'It is in Turkey' [...] A young man stood up, and looking at the teacher nervously, fired at Mathilde in a loud voice, 'How many wives has your father?' [...] 'One,' said Mathilde, 'We live in Turkey, yet we are not Turkish. Of Arabs and Muslims you are thinking' [...] 'You are French like myself, nést pas?' said a girl [...] 'No', said Mathilde smiling. 'Many times people think I'm French,

3 Azose is the member of the Sephardic community of Seattle who possesses the only original copy in the United States of the method to learn English published by the newspaper La America: Libro para embeźar las linguas ingleśa y yudiš. 
because I speak with the accent. But this is because the school I attended in Turkey was a French school. We spoke also the French [...] My people came from Spain. But that was long ago' [...] and suddenly everyone was talking at once, telling of their homelands and their families. And the many different people were speaking in one tongue... and Mathilde thought it was beautiful to hear." (Benforado 2005: 57-61)

\section{Teaching Methods}

Last of all we are going to mention three very different methods aimed at teaching immigrants English. The vast majority of such methods was directed to Russian Jews, i.e., Ashkenazim and were taught through Yiddish. Perhaps the best known is Ollendof's Method to Acquire a Thorough Knowledge of the English Language Without the Aid of a Teacher published in 1893 by Alexander Harkavy. It consists of over 600 pages. Although it seems highly unlikely that anybody could teach himself English with such a long method, two things are worthy of note here. First, the huge number of sentences does not follow any kind of order, they are not conversations or situations. Second, the aljamiado English transcription, unlike all aljamiado texts does not read from right to left but from left to right.

Next, referring back to the document entitled English classes of the Baron de Hirsh Fund mentioned earlier, we find a letter dated June 26, 1914 from the American Book Company which says that it is sending under separate cover a book entitled Practical Language Lessons for New Americans and requests that it be put into the hands of the teacher who has charge of the classes learning English. ${ }^{4}$ This method is only in English and in the preface authors Markowitz and Starr state that:

"The aim of this book is to supply or to suggest, to the teachers of adult New Americans in the evening schools material wherewith to teach their pupils in a reasonably short time and in a practical manner, to speak, read and write the English language."(Markowitz/ Starr 1914: 5)

It starts with the introduction of long and short vowels, introduces verb tenses and irregular verbs and includes in its chapters such things as letter writing, information about America, education, fables and morals, etc. Lesson 105 section 1 entitled "The Early Struggles of an Immigrant" clearly indicates that this book is also aimed at the Ashkenazim as seen by the example on page 163: "Joseph Belman landed in New York in 1902. He had left oppressive Russia to seek his fortune in free America."

4 I would like to thank the archivist of the AJHS for sending me a scanned copy of this English method. 
And thus we come to the so far only known method directed specifically to the Sephardim, Gadol's Libro de embeźar las linguas ingleśa y yudiš published in $1916 .{ }^{5}$ Gadol most likely included Yiddish precisely because it was the majority language among the Jewish immigrants, the language the Sephardim undoubtedly heard where they lived and where they worked and initially the need to learn Yiddish may very well have prevailed over that to learn English. The method itself consists of two parts: vocabulary (540 words) and conversation, both of which can be considered avant-garde for its time. Unlike Ollendof's method where there are hundreds of sentences having no relationship to each other, Gadol's conversation is actually what is known nowadays as the Situational Language Teaching Method which was developed by British applied linguists in the 1930s to 1960s. The different conversations which appear in Gadol's method represent situations found in everyday life such as renting a room, finding a job, the need to buy new clothes, etc. Gadol's aim was to provide the Sephardic immigrants with basic English and Yiddish needed for survival in the United States.

\section{Conclusion}

In conclusion, when the Ashkenazim and Sephardim arrived in the United States their integration into the new country depended on learning English. Due to the fact that they lived in the same neighborhoods as their co-religionists and worked in factories where their fellow employees as well as their employers spoke Yiddish, the Sephardim found it necessary to learn Yiddish as well, which no doubt slowed down their integration into the wider American society.

I have examined here the role played by various Jewish organizations in English acquisition as well as the different classes that were organized and the teachers who taught them. Only the English classes in all probability given by the Sisterhood of Shearith Israel and Gadol's Libro de embeźar las linguas ingleśa y yudiš were conceived specifically for Judeo-Spanish speakers, which means that Sephardic adults learned English either through Yiddish or through English classes given for immigrants, both Jews and non-Jews alike. Children who did not have to work, both Ashkenazim and Sephardim, learned English in public schools or to some extent in Jewish schools. Thus, plenty of opportunities were at the disposal of those Jewish immigrants who wanted to learn English and embrace their new homeland.

5 See (Scolnik 2014). 


\section{References}

Angel, Marc (1982): La America: The Sephardic Experience in the United States. Philadelphia.

Benforado, Sally (2005): Bring Me More Stories: Tales of the Sephardim. California. Ben-Hur, Aviva (2009): Sephardic Jews in America: A Diasporic History. New York.

Bortnick, Rachel Amado (1989) [unpublished manuscript]: The Americanization of a Sephardic Turk. American Jewish Archives, Cincinnati.

Brumberg, Stephan F. (1986): Going to America, Going to School: The Jewish Immigrant Public School Encounter in Turn-of-the-Century New York City. New York.

Diner, Hasia R (2004): Jews of the United States 1654 to 2000. Berkeley, Los Angeles.

English Classes, n.d. 1890-1900, 1913-1914 [unpublished manuscript]. American Jewish Archives, Cincinnati.

Gadol, Mois (1916): Libro de embeźar las linguas inglesa y yudiš. New York.

Gartner, Lloyd (1969): Jewish Education in the United States: A Documentary History. New York.

Grey, Christopher (1996): Streetscapes/Aguilar Library, 174 West 110th Street; A Library Branch That Wasn't Designed by the Book. In: New York Times June 9, www.nytimes.com/1996/06/09/realestate/streetscapes-aguilar-library-174-west110th-street-library-branch-that-wasn-t.html [last accessed on 28-06-2017]. Harkavy, Alexander (1893): Ollendof's Method to Acquire a Thorough Knowledge of the English Language without the Aid of a Teacher. New York.

Howe, Irving (1976): World of Our Fathers: The Journey of the East European Jews to America and the Life They Found There. New York.

Markowitz, Alfredo/Starr, Samuel: (1914) Practical Language Lessons for New Americans. New York.

Matza, Diane (ed.) (1997): Sephardic-American Voices. Two Hundred Years of a Literary Legacy. Hannover, London.

Papo, Joseph (1987): Sephardim in Twentieth Century America: In Search of Unity. San Jose.

Scolnik, Julie (2014): Libro de embeźar las linguas ingleśa y yudiš: La América’s Guidebook to Learning English and Yiddish and Becoming an American Citizen. In: Miscelánea de Estudios Árabes y Hebraicos. Sección Hebreo 63, 1-13. 



\title{
Izabela Olszewska and Aleksandra Twardowska
}

\section{A Positive Image of Yiddish and Judeo-Spanish in the Jewish Press of the First Half of the 20th Century: An Overview}

\begin{abstract}
The article presents discourse in the Jewish press on the question of the Yiddish and Judeo-Spanish languages and accordingly, their important roles in Ashkenazi (here precisely of so called Westjuden) and Sephardi environments. The positive image of the languages is illustrated in the press texts from Germany and Bosnia. Taking account of different social, political, cultural and linguistic conditions of both Jewish groups, the overview aims to find similar patterns in the presence of Yiddish and Judeo-Spanish in studied Jewish magazines.
\end{abstract}

Keywords: Yiddish, Judeo-Spanish, Westjuden, Sephardi Jews, Germany, Bosnia, Jewish Press, Discourse in the Press

\section{Introduction}

"On the eve of the twentieth century, European Jewish culture was in a state of dramatic flux. Though never rigid, some of the most important emblems and agents of Jewish identity were now being reconsidered as cultural norms. The language one spoke, the food one ate, where one lived, how one dressed or self-identified, the class or professional status one might attain, the influence of communal loci power, the importance of religious practice: all these were increasingly matters of choice rather than convention.”

This is what Sara Abrevaya Stein wrote (2004: 1) introducing her studies on the modern Jewish European press. On the other hand, in the after-empire period, as Abrevaya Stein indicates (2004: 207), the majority of the Jews in eastern and south eastern Europe still pointed to Jewish vernacular languages as their mother tongues, in spite of a growing degree of fluency in national languages. Unsurprisingly, we note more ambiguity in the status of both Yiddish and JudeoSpanish among Ashkenazi and Sephardi Jews in the first half of the 20th century: the languages in question were described as determinants of the Jewish nationality and Jewish culture, but some people underlined their decline, and we can even observe that there was a disrespectful attitude towards these languages even among their speakers, for example in the case of Judeo-Spanish (see Olszewska/Twardowska 2016: 79-103).

The aim of the article is to present an introductory sketch of the positive evaluation of both Diaspora languages as well as discourse in the Jewish press that 
showed their important role in the Jewish culture and tradition. The chosen sources originate from the regions where the situation of Jewish citizens was much different in social, cultural, political and sociolinguistic terms: Germany and Bosnia (at that time a part of the Kingdom of Yugoslavia). The source material has been excerpted from the Jewish German language and bilingual JudeoSpanish/Serbo-Croatian press of a socio-cultural type, which in line with its statutory objectives covered issues related to the Jews, their language and culture. First, let us briefly characterize the selected written sources.

The Jewish German language press of a socio-cultural type that brought up topics oscillating around the East European Jews, their language and culture included Ost und West [East and West] ${ }^{1}$ (1901-1923), Die Freistatt [The Asylum] (1913-1914), Der Jude [The Jew] (1916-1928), Der Morgen [The Morning] (1925-1938) and Die Welt [The World] (1897-1914). The interest of the press in Eastern European Jewish topics was rooted in current socio-political and economic happenings, such as migrations of the Ostjuden to Western Europe and to the USA, contacts with the strange culture of the Ostjuden during the First World War or increasing anti-Semitism in Germany.

Ost und West, one of the oldest Jewish journals in Germany, published for 23 years, was a body of Alliance Israélite Universelle, the organization, which promoted positive ideals of Jewish emancipation and self-sufficiency through education and professional development. The aim of Ost und West was to inform the assimilated Jews about the cultural, literary and scientific achievements of the Ostjuden. Another example of a Jewish German language journal that covered topics related to Yiddish was Die Freistatt. According to the founders of the journal it was the general Jewish political and cultural review. Die Freistatt existed on the German language press market merely for two years. The aim of the monthly was to unite the assimilated German Jews. The journal categorically distanced itself from the Zionist views and, within the framework of the general Jewishness programme, opted for the necessity to accept the socio-cultural world of the Ostjuden. The monthly Der Jude, with its editor-in-chief Martin Buber, promoted the ideals of cultural Zionism and gave special attention to the topics related to the East European Jews. The monthly Der Morgen, founded by Julius Goldstein and published mainly in the interwar period, consisted of two parts: the main part, in which social, religious and political matters were discussed, and the other containing reviews and previews of publications.

1 The titles and quotes from the Jewish German language press were translated by I.O. and from Serbo-Croatian and Judeo-Spanish by A.T. 
The written sources of Judeo-Spanish and Sephardi culture after 1914 are articles from the Jewish weeklies published in Sarajevo and read in entire Bosnia and Herzegovina. There are two periodicals (out of seven published in Bosnia before World War II) presenting a positive image of the language of the Sephardim: Jevrejski život [The Jewish Life] (1924-1927) and Jevrejski glas [The Jewish Voice] (1928-1941).

Jevrejski život was a body of the Sephardic Movement in Bosnia. The clash of Zionism and the Sephardi movement is one of the most interesting phases of pre-war Jewish history in Bosnia (see Loker 1997). We can observe the beginnings of the Sephardic Movement at the end of the 19th century when the appearance of this national ideology coincided with the outset of the westernization of the Sephardim. In Bosnia it gained strength especially in the 20 s of the 20th century, first, under the influence of Vienna and then Zagreb association "Esperansa". The Bosnian propagators of the Sephardic Movement were not against the fundamental ideology of Zionism, but they put effort into the emancipation of the Sephardim which should go along with the preservation of the Sephardi identity and tradition. Jevrejski glas was supposed to be a rostrum which would combine the profiles of both fractions - Zionist and pro-Sephardic.

Jevrejski život and Jevrejski glas were bilingual. Their articles were printed in Serbo-Croatian and Judeo-Spanish. The linguistic policy of the magazines also shows the sociolinguistic situation in the Bosnian Sephardic community: the years 1918-1941 are the period during which Bosnia was a part of the Kingdom of Yugoslavia and all the Jews were rightful citizens. It is the period of the assimilation of most Sephardic Jews, their participation in public life and, in linguistic terms, the period of language shift and bilingualism during which they acquired the Serbo-Croatian language.

\section{Language of the Ostjuden as a Topic in the Jewish Press in Germany}

The Yiddish language as "Umgangssprache der osteuropäischen Juden" (Ami 1914: 567), that is "colloquial language of the East European Jews" or "tatsächlich die gegenwärtige Volkssprache der Judenheit par excellence” (Schach 1901: 179) i.e. "actually the modern language of Jews par excellence" was not merely a means of communication but also a determinant of their affiliation to a given social group and a characteristic sign of its culture. Its function of creating and strengthening the Jewish identity was underlined in the press: "This language became our little homeland. Every word we uttered there was a reminder and 
a guarantee of possessing a homeland [...]" (Kaznelson 1923: 440). In the discourse of the press the Yiddish language was general present. It was practically mentioned with regard to all aspects of social life - education, religion, identity and literature. The discussion on Yiddish in the Jewish German language press focused first of all on general language characterization, cultural and social events, the Yiddish press and literature, as well as linguistic and ethnological analysis.

As stated by Aschheim (1982: 115): "Nineteenth-century German Jews had consistently regarded Yiddish as a tasteless, mongrel Jargon, a bastardized vulgarization of German, the embodiment of a narrow, obscurantist ghetto spirit". During World War I, however, Jews from the German army fighting in Eastern Europe were confronted with millions of Yiddish-speaking Jews and since then we could see a noticeable increase of interest in the Yiddish language among assimilated Westjuden. ${ }^{2}$ The Jewish German language press underlined the role of Yiddish in creating and strengthening the Jewish identity. It was the very titles that already included, in accordance with their communicative function, basic information referring to the perception of the Ostjuden culture and language in the press. Most of the titles were of informative character, for example: "Der deutsch-juedische Jargon und seine Literatur" [GermanJewish Jargon and Its Literature] (Schach 1901); "Jiddisch" [Yiddish] (Calvary 1916); "Unsere Stellung zum Jiddischen” [Our Position Concerning Yiddish] (Bergmann 1914); there were also titles incorporating language parallels "Jüdisch-Deutsch und Jüdisch-Spanisch" [German-Jewish and Judeo-Spanish] (Perles 1925), alarming titles - "Grenzsperre" [Border Blockade] (Kaufmann 1916), intriguing titles - "Gedanken zum jetzigen Problem" [Reflections on the Current Problem] (Paquet 1916), or titles incorporating family names - "Leon Perez. Ein moderner jüdischer Dichter" [Leon Perez. A Modern Jewish Poet] (Eliaschoff 1901).

2 The ethnonyms Westjuden and Ostjuden coined by Natan Birnbaum, one of outstanding Jewish thinkers at the turn of the century, started to function as terms defining two separate types of European Jews. Birnbaum, named a "living exponent of Jewish intellectual history", was a prime mediator and interpreter of Ostjudentum to West European Jewishness (see Aschheim 1982: 114). The term Ostjuden denotes the Jews originating from Eastern Europe and living in line with old tradition, while the ethnonym Westjuden - the assimilated West European Jews. Cf. the leaflet Was sind die Ostjuden? Zur ersten Information (1916) or press materials: Acher (1904), Acher (1913), Birnbaum (1913). 


\subsection{A General Characterization and Evaluation of Yiddish in the Press}

According to Best (1998: 14) the word Jiddisch derives from the Middle-High German adjective 'jidish', i.e. 'Jewish'. Initially the meaning of 'Jewish' and 'Yiddish' was the same. In the dictionary of German Jews Jüdischen Lexikon from 1927 under the entry 'Jewish language' Yiddish is explained as 'jüdischdeutsch'. In press articles from the first half of the 20th century there appeared a synonymous expression - 'jüdisch-deutsch' which means the Jewish-German language. Other used terms were: a jargon, the language/dialect of the Ostjuden, a mixed language or idiom. The press also used pejorative Yiddish expressions that functioned among the assimilated Westjuden, for instance Lallen 'mumble', Kauderwelsch 'obscure jargon' or mauscheln 'gibberish':

"Anyway he [Graetz] did not see among the Hassidim anything more than a system of stupefaction, he sneered at 'a complicated and funny method' of Polish teachers of Talmud, he specified their way of thinking as inappropriate, their language as a disgusting mixed language, hideous mumble, incoherent jargon [...]."4 (Meisl 1917: 475)

or: "The jargon of Russian Jews is not a 'gibberish" "5 (Schach 1901: 179).

Press articles alluded to the origin of the Yiddish language, its cultural connections and its role in the lives of the East European Jews since migration at beginning of century. The texts were informative and opinion-forming:

"Jargon is a living language of a wide social group. It does not irritate the ear as the speech of the South German cattle traders does. It is not ugly. It does sound hard indeed like any national language but it attracts with its freshness. It is robust, sarcastic, vivid, concise and temperamental. Language that like no other suits the Jewish nation." (Schach 1901: 179)

As it was already mentioned, the interest in Yiddish increased after 1914. On the battle field the assimilated German Jewry came across Yiddish language and culture that were alien to them:

3 Other Yiddish and Ladino expressions in the Jewish press, cf. Olszewska/Twardowska (2016).

4 Gm. "So sah er bei den Chassidim nichts als ein 'Verdummungssystem', spottete über die 'kniffige, witzelnde Methode' der polnischen Talmudlehrer, bezeichnete ihr Denken als 'verkehrt', ihre Sprache als eine 'häßliche Mischsprache', 'ein widriges Lallen und Stammeln', ein 'Kauderwelsch' [...]."

5 Gm. "Der Jargon der russischen Juden ist kein 'Mauscheln." 
"The language of Ostjuden, that is Yiddish, is less familiar to you than some exotic dialect. [...] This rich knowledge of the nation, economy and society and even the literature in Yiddish, old legends, Jewish songs or proverbs, folklore and poetry written in this language are still inaccessible to you." ${ }^{6}$ (Kaufmann 1916: 14)

\subsection{Yiddish in the Linguistic Context}

In the press Yiddish was also characterized in the linguistic context. We come across information referring to the origin of Yiddish, its history, linguistic and cultural connections and the fact that "Yiddish is a mixed language caused a great deal of difficulty to Jewish philologists"” (Ami 1914: 556).

The origins of Yiddish as a mix-language and its components were described in the Jewish press:

"The Jewish language consists mostly of Germanic words, its forms are almost with no exception Germanic. Above that it betrays many Semitic (Hebrew and Aramaic) words and forms. Particularly syntax and style is Semitic. Yiddish also partly took over Slavic, Romanian and Hungarian words and forms and in recent days also English in the United States. Eventually we find in Yiddish a small but highly interesting group of Roman elements (Old-French, Italian and Portuguese) [...]." (Ami 1914: 566)

Important events were reported (events related to the status of Yiddish in the contemporary Jewish world), for instance the Czerniowitz Language Conference, which was the first international conference on the role and significance of Yiddish. It was held in the town of Czerniowitz in Ukraine in 1908. The aim of the debate was to acknowledge Yiddish as the national language of Jews. The conference was an important stage in the development of the Yiddishist movement:

6 Gm. "Die Sprache der Ostjuden, das Jiddische, ist ihnen unbekannter als ein exotischer Dialekt. [...] Das reichhaltige, in dieser Sprache vorliegende statistische, volks-, wirtschafts- und gesellschaftskundliche Wissen, oder gar die Quellen des jiddischen Schriftwerks, die alten Legenden, die Volkslieder, die Gleichnisse und Sprichwörter, die Folklore und die im 19. Jahrhundert hochauf sprießende erzählende und dramatische Dichtung sind ihnen noch immer verschlossen."

7 Gm. "Große Schwierigkeiten erwachsen den jüdischen Philologen aus dem Umstand, daß das Jüdische eine Mischsprache ist."

8 Gm. "Das Jüdische besteht überwiegend aus germanischen Wörtern, seine Formen sind fast durchweg germanisch. Außerdem weist es sehr viele semitische (hebräischaramäische) Wörter und Formen auf. Besonders semitisch ist der Satzbau und der Stil. Zum Teil hat das Jüdische auch slawische, rumänische, ungarische Wörter und Formen aufgenommen, in letzter Zeit in Amerika auch englische. Schließlich finden wir im Jüdischen eine kleine, aber um so interessantere Gruppe von romanischen (altfranzösischen, italienischen und portugiesischen) Elementen [...]” 
"Certain Jewish writers including the well-known and recognised, but also amateurs - gathered in Czerniowitz to offer a decisive solution to the issue of the Jewish language. After discussions, both extensive and shorter, the conclusion [...] was made that the only national language of Jews is no less than a Jewish 'jargon."' (Coralnik 1908: 619/620)

\subsection{The Yiddish Press and Literature}

On the one hand, the information relating to the Yiddish press and literature proves the existence of a strong Ostjuden culture in Germany; despite the dependence on other countries and cultures and the fact that, as we read in Der Jude: "Yiddish as a language is exceptionally young" (Paquet 1916: 506). On the other hand, the fact of frequent touching upon themes referring to Ostjuden was an attempt to improve their image in the society of German Jewry. The weekly Die Welt was issued in Yiddish, so the unassimilated Eastern European Jews could get informed about various events in the world. Ost und West featured the column "Revue der Presse" covering the review of the Jewish press, also in Yiddish. Ost und West also published entire texts referring to the Yiddish press, for example "Die hebräische und jargonische Presse im Jahre 1908" [Hebrew and Jargon Press in 1908] (Lin 1909), "Die ostjüdische Presse" [The Yiddish Press] (Lin 1907). One could also learn where new magazines in Yiddish were published.

The German-Jewish press informed about cultural events involving Yiddish, for example theatrical performances, the cultivation of Jewish traditions or reported on the socio-cultural lives of the East European Jews in general. Editorial staff encouraged the readers to participate in concerts of Jewish songs and poems, and in Ostjuden cultural meetings, during which one could learn about, for instance, Yiddish schools. Moreover, in line with their character, the magazines published information on literary achievements of the Eastern European Jews, for instance the information about new books or German translations of Yiddish books. They also covered translations of famous Jewish authors, such as: "Mendel Moicher Seforim or Scholem Aleichem [who] in their creation

9 Gm. "Einige jüdische Schriftsteller, darunter auch solche von Namen und Wert, und einige Amateurs des Jargons, haben sich in Czernowitz versammelt, um die Sprachfrage im Judentum endgültig zu entscheiden. Jargons, haben sich in Czernowitz versammelt, um die Sprachfrage im Judentum endgültig zu entscheiden. Und nach längeren oder kürzeren Debatten wurde eine Resolution eingebracht und angenommen [...], daß die einzige Nationalsprache der Juden der jüdische 'Jargon' sei." 
abundantly drew from the Yiddish language and culture, which cannot be mistaken with any German high culture"10 (Calvary 1916: 31).

\subsection{Yiddish Ethnology and Anthropology}

The German language Jewish press described the strange culture of the Ostjuden making use of texts on tradition and religious practices. Much attention was devoted to describing the culture of Ostjuden, their customs, everyday life or religion, mainly through the comparison of the Westjuden and Ostjuden: "Deutsche Juden und polnische Juden" [German and Polish Jews] (Berger 1916). We also find a number of texts that offer a general characterization of the Ostjuden, for instance in the article "Zur jüdischen Sprach- und Volkskunde" [On the Jewish Language and Ethnology] (Ami 1914), or "Aus dem religiösen Leben der Ostjuden" [From the Religious Life of the Ostjuden] (Rappaport 1917/1918). Jewish holidays, for example, were described in the following words:

"The one who participates in any holiday or an ordinary Sabbath among Ostjuden and who experiences the accompanying joy of spirit and feels joyful atmosphere can affirm the living force that comes out of the spirit. This person knows that all the riches and material goods of this world mean almost nothing in the face of unlimited happiness of 'being a Jew'. Jewishness is not a burden imposing religious rules or a customary imperative." ${ }^{11}$ (Rappaport 1917/1918: 340)

Apart from the descriptions of the culture of Ostjuden, which were practically noted in all texts analyzed in this article, much attention was devoted to the characterization of the Yiddish language in ethnological and anthropological contexts.

Die Welt, for example, featured information referring to the activity of the Jewish Ethnological Society, Ost und West printed the characterization of Jewish legends and tales. It was already in 1905 that one could read in Ost und West: "In the new year that is just commencing our editorial staff intends to intensify

10 Gm. "So verschiedene Schriftsteller wie Mendel Moicher Seforim und Scholem Aleichem haben ganz aus jiddischem Lebensgefühl und jiddischer Sprache heraus ihre Formen geschaffen, unverwechselbar mit irgendwelcher hochdeutschen Kunst."

11 Gm. "Wer je einen Feiertag oder einen gewöhnlichen Sabbat unter den Ostjuden und die unter ihnen herrschende Seelenfreude und heitere ungetrübte Stimmung miterlebt und mitempfunden hat, kann die lebendige Kraft beurteilen, die aus diesem Geiste strömt. Er weiß es, wie wenig sämtliche Reichtümer und Güter dieser Welt gegenüber dem unbegrenzten Glück, 'ein Jüd zu sein', bedeuten. Das Judentum ist hier nicht eine beschwerende Last, welche ein religiöses Gebot oder ein sittlicher Imperativ zu tragen gebieten." 
work on Jewish ethnology" and make it more familiar, because: "We Jews are shamefully behind in this respect. It is high time we got to work" (Redaktion von Ost und West 1905: 1 and 3). The collection was described as "imposing" and included Jewish songs, tunes, proverbs, legends, fairy tales, depictions of folk costumes, customs, folk medicine or beliefs "reflecting the worldview, way of life and spirit of the nation" (Redaktion 1905: 3).

Bar Ami (1907: 15) wrote in the introduction to one of the initial articles in the series "Aus der jüdischen Sagen- und Märchenwelt" [From the World of Jewish Legend and Fairy-Tale]: "I took down the following tales many years ago after they were told to me by a Hassidic story teller. The introduction [...] perfectly reflects both naive and mystic world-view of the Hassidim. The translation into German renders the original as close as possible." ${ }^{12}$

In the context of the Yiddish language we also come across some information on Jewish proverbs. The proverbs of the Ostjuden, especially in Ost und West, were described both broadly and in detail, for instance thematically, cf. "Die Bernsteinische Bibliothek" [Bernstein's Library], "Der Jude und seine Umwelt im jüdischen Sprichwort" [The Jew and His Environment in Jewish Proverbs], "Die Frau im jüdischen Sprichwort" [The Woman in Jewish Proverbs] or "Das Geld im jüdischen Sprichworte" [Money in Jewish Proverbs]. Bernstein's library was described by Segel (1901: 357): "One of the most extraordinary and most interesting collections of books in Europe is the one belonging to the private assemblage of Ignaz Bernstein in Warsaw. [...] The library encompasses 4761 titles [...]."13

Texts about folk songs, apart from the information on proverbs, were widespread - one of the most renowned researchers of the Jewish folklore, Arno Nadel wrote: "Some songs were very old - many had been created hundreds of years before. Almost all of them were in the old or new Jewish-German language, a so-called jargon [...]" (Nadel 1916/1917: 112). The evening parties of cultural societies (so-called Jüdischer Liederabend) were organized to

12 Gm. "Die folgenden Sagen sind von mir vor mehreren Jahren nach dem Vortrage eines chassidischen Märchenerzählers aufgezeichnet worden. Die vorangehende Einleitung bildet gleichsam ein Präludium und spiegelt trefflich die naive und zugleich von einem gewissen mystischen Schwung beseelte Anschauungsweise der Chassidim wieder. Die Uebertragung ins Hochdeutsche schliesst sich möglichst wortgetreu dem Original an."

$13 \mathrm{Gm}$. "Eine der merkwürdigsten und interessantesten Büchersammlungen in Europa bildet diejenige eines Privatmannes, Herrn Ignaz Bernstein in Warschau [...]. Eine Bibliothek, die 4761 Titel umfasst [...]." 
present "Jewish songs which were considered to have become extinct a long time ago." ([anonym] 1907: 71/72)

\section{The Sephardi Press in Bosnia after World War I}

Sarah Abrevaya Stein writes about the Judeo-Spanish press in the Ottoman Empire:

\footnotetext{
"The earliest editors of the Ladino ${ }^{14}$ press not only created new genres of texts, but also envisioned new kinds of Ladino readers. [...] At least theoretically, [...] Ladino newspapers $[\ldots]$ were designed to reach all readers of Ladino, regardless of age, gender, religious status, educational background, class or professional standing." (Abrevaya Stein 2004: 61)
}

She assigns that role to the magazines like El Tiempo published in the area of today's Turkey in the second half of the 19th century, but it is also valid in the case of the Bosnian-Sephardi press of the 20th century. In 1900/1901 Abraham Cappon, the editor of the self-published La Alborada, the first JudeoSpanish magazine in Bosnia, who was aware of the fact that the majority of the Sephardim in Bosnia fluently spoke only Judeo-Spanish, intended to create modern local Judeo-Spanish readers from all social strata. As he failed in his efforts, because of the lack of funds, he admitted: "[...] and even though I did what I could to make this magazine available for as wide circle of readers as possible, not many people appreciated my goals" (Vidaković-Petrov 1986: 53). Later on, after World War I, the editorial board of Jevrejski život and Jevrejski glas made a gesture towards the Sephardi readers. Newspapers were run in a professional way, supported financially and published in different political, social and cultural conditions. According to Krinka Vidaković-Petrov (see 1986: 55, 2013: 31, 32) Jevrejski život and Jevrejski glas had to deal with two issues which were major for the local Jewish community in that period: of joining the Zionist movement or submitting to acculturation. Another question concerned the position of Sephardi and Judeo-Spanish tradition in the stream of changes. Jevrejski život, which was a body of the Sephardi Movement in Bosnia, showed loyalty towards the Sephardi heritage and language. The importance of the language was shown in the press sources in various ways: from its positive evaluation, the publication of various genres of Judeo-Spanish texts, to the support of cultural events linked to Sephardi/ Judeo-Spanish tradition.

14 Abrevaya Stein uses the term Ladino for the vernacular of the Sephardim. 


\subsection{A General Characterization and Positive Evaluation of Judeo-Spanish}

The Sephardic Jews' language in selected press articles is given different names: lingva žudia, lingua žudia-spaniol, lingua espanjola, judio-español, žudio-espanjol, španjolski jezik, španjolski žargon, jevrejsko-španjolski, sefardski idiom, jevrejsko-španski idiom. The sources most often call the Sephardic Jews' speech 'a language' but the terms 'an idiom' and 'a jargon' are also used. We should also note that, as indicated by the way they were used, the terms 'a jargon' and 'an idiom' do not seem to have any negative connotations. The debate in the Jewish press in Bosnia focused mainly on the range of representative and communicative functions of the language, while it was always highlighted that the language was closely connected with the Sephardic tradition. When we think of how the condition of the language at that time was described, the opinions were various: from the view displaying a constantly present role of the language as a means of communication, to the opinion showing its decadence and slow decline. The selected sources that underlined the important role of the language often represented sentimental perception of it, idealizing its roles of a language of tradition, a factor uniting the closest community and a still vital language of communication. They said that JudeoSpanish was: "[...] the Jewish language with innovations, the adapted and rich language, with nuances and dialects"15 (Attijas 1927: 3). The loyal attitude towards the language, as mentioned above, was characteristic of the discourse in Jevrejski život, which due to its ideology and political views focused on the Sephardi issues.

It was also believed that Judeo-Spanish (as a so-called "segundo hebreo" - 'the second Hebrew'), integrated all Sephardic communities in the region and differentiated them from other groups of the Diaspora and, last but not least, as it was a particular determinant of the Jewish identity, it was often called "a national language"16 ("A las komunidades..." 1927: 2).

At the beginning of the 20th century in the discourse on the language of Balkan Sephardic Jews this language was very often described as a language of a family circle: "language after the mother" ("Una nočada literaria" 1925: 2), "we heard this language from the cradle"17 (Bitton 1939: 5). These expressions are

15 JSp. “[...] lingva žudia de novideades, lingva akomodada i rika, tiene niansas i dialektos."

16 JSp."lingua nasionala."

17 Serb.-Cr."maternji jezik”, “[...] smo čuli taj jezik još od naše koljevke.” 
associated with two features of the language: during that period it mostly functioned as the language of the closest environment (a home, backyard, district) and also happened to be the first language of its users. At the same time, it was shown that there were still Jewish citizens in Yugoslavia for who Judeo-Spanish could be the only language of communication. The articles from the 1920s mentioned readers in Bosnia and so-called Southern Serbia (today's Macedonia) "[...] who still speak espanjol and only a bit in Serbo-Croatian"18 ("Muestras publikasjones..." 1924: 2).

At the same time, even the supporters of the Sephardic Movement had to face the fact that in the 1920s the Judeo-Spanish language in the Balkans started to compete with the languages of the surroundings (Serbo-Croatian and others) and with the need for promoting the Hebrew language (in relation to Zionist trends). Nevertheless, the intellectuals of the Sephardic fraction like Eliezer Levi often had doubts about the role of Hebrew as the national language of the Jewry. It was believed that the Judeo-Spanish language still had the advantage over Hebrew in that its "spirit harmonized with Sephardic mentality", whereas Hebrew was not a language close to the Sephardic Diaspora and it would be difficult to learn it (E. Levi 1927b: 2).

Bosnian Jewish press often published calls for other practical solutions to preserve Judeo-Spanish and Sephardi culture among the readers of the weeklies. For example: Jevrejski glas and Jevrejski život published several calls from the associations "La Benevolencija" and "La Lira" for the Jewish inhabitants of Bosnia to gather Judeo-Spanish folklore texts and traditional songs (see, for example: “Glavna skupština...” 1931: 4). After the Sephardi Youth Congress in 1927 Jevrejski život called for gathering of grammatical and lexical corpus of Judeo-Spanish and informed about a newly formed committee for JudeoSpanish. One of the goals of the committee was to publish Judeo-Spanish grammar and dictionary ("Rezolucije" 1927: 4). Unfortunately, according to our knowledge, it never happened before the outbreak of World War II. Unlike in the Jewish press from Germany referring to Yiddish, there were very few attempts at a linguistic description of Judeo-Spanish in Bosnia. Jevrejski glas published an article in the form of a short etymological dictionary of Hebrew borrowings in the language (Maestro 1929: 6-7). In 1930 the same weekly contained a resume of Kalmi Baruh's (a Sephardi Hispanist from Bosnia) doctoral dissertation on phonology in Judeo-Spanish in Bosnia (E. Levi 1930: 8).

18 JSp. “[...] ke konosen espanjol i solo poko serbo-kroato." 


\subsection{Sephardi Events and Organizations in the Press}

The press always informed (in both the Serbo-Croatian or Judeo-Spanish language) about cultural and social events connected to Sephardi culture, such as public lectures (for example, Laura Papo-Bohoreta's lecture ${ }^{19}$ about Sephardi women) evening-time tea parties (so called čajanke) with singing of Sephardi traditional romansas (songs of epic character) and kantikas (lyrical songs), etc. Sometimes the magazines called for the readers to take an active part in the events in order to have an opportunity to show still present connection to the Judeo-Spanish tradition:

"We are talking about a decision of the new 'La Lira' committee [...] popularization of our literary works, no matter if they are a product of popular wisdom or fruits of our poets and writers $[\ldots]$. We do not want to lament over the loss of our literary treasure $[\ldots]$ we see it as a tiny light in our cultural twilight. [...] on the 27th of this month [...] a night of romansas will be held, in which everybody who knows romansas and knows how to sing them can take part." ${ }^{20}$ ("Nueva actividad..." 1932: 7)

Furthermore, every premiere of Bohoreta's play was noted and acclaimed, for instance in an article by Benjamin Pinto about the premiere of "La Madrasta i el nombre le abasta" [Mother-In-Law and Her Name Says Enough], where he devotes much attention to Laura Papo's contribution to fostering the Sephardi culture and the vivid Judeo-Spanish language which she uses in her comedies:

"All the more she is one of rare experts or connoisseurs of our mahalas, our customs, language, our folklore in general, her knowledge is on expert level and she saves it in various literary forms, at least she keeps and fosters it on paper. [...] she gave us so many vivid and interesting linguistic combinations, many images, metaphors, the power of sayings and proverbs [... ${ }^{\text {?21 }}$ (Pinto 1935: 2-3)

19 Laura Papo, pseudonym "Bohoreta" (1891-1942) - one of very few Sephardi women actively present in the public Jewish discourse in the former Yugoslavia. She was a poet, playwright and short story writer, as well as a collector of Sephardi folklore samples from Bosnia. Before War World II she published only in the Jewish press (see: Nezirović 1992: 503-525, 548-549, 585-599; Vidaković-Petrov 1986: 100-104, 119, 120; Večerina Tomaić 2016).

20 JSp. “Se trata aki de una dečizion del nuevo komite de „la Lira” [...] el popularizamiento de de nuestras ovras literarias, sejan ejas el producto del ženio del puevlo, sejan ejas frutos de nuestros poetas i eskriptores [...]. No keremos lamentar por el deperdimiento de nuestro tesoro literario [...] lo tratamos komo una čika luz en nuestra skuridad kulturala. [...] al 27 del mez koriente [...] esto va ser una noće de romansas en la kuala van tomar parte akejos ke las konosen i las saven kantar."

21 Serb.-Cr. "Tim više je ona jedan od rijetkih poznavalaca naših mahala, naših običaja, našeg jezika, našeg folklora uopće, da je to njeno poznavanje stručno i znalačko i da 
The weeklies also informed about meetings or congresses organized by Sephardi associations. Not only local, but also those involved in a wider range of activity, like "Esperansa" formed in Vienna in order to maintain Sephardi tradition (Esperanzista 1924: 2). A special event held in Sarajevo in 1927 - the Sephardi Youth Congress - drew much attention of the local Jewish press and many articles were devoted to it. There was a journalistic debate not only about the question of the Sephardi movement in general, but also about Judeo-Spanish itself, which was one of the congress's topics. Especially Jevrejski život published many articles about resolutions of the congress related to the language, its condition and future, which was a call for the preservation of the language, and according to the editors was a very important question for the local Sephardi group and the Sephardi Movement in general:

"The Sephardi Youth Congress finds the Judeo-Spanish language, which still is a maternal language of a big part of the Sephardi Jewry and has its own historical, cultural and national value, a component of the Sephardic ideology and an important factor of the Sephardic Movement."22 ("Rezolucije" 1927: 4)

\subsection{Texts in Judeo-Spanish}

There were many samples of Judeo-Spanish texts printed in the local press in the 1920s. The editorial board of the weekly Jevrejski život, active in dealing with Judeo-Spanish language issues, during the first year decided to publish more texts in the language, which was doubtless connected to the ideology of the Sephardi Movement. The second reason for the decision was practical: as the editors wrote, not so many Bosnian (and Macedonian) Sephardim spoke Serbo-Croatian at that time, so Judeo-Spanish columns were useful for that group of readers. The linguistic policy of the magazine was presented in the essay "Muestras publikasjones en espanjol" [Our Publications in Spanish], which says:

"The editorial board of Jevrejski život made a new decision. It is a novelty which in the city of Sarajevo, as well in the provinces (especially in South Serbia) will be surely well received by the readers of our magazine: our publications in Spanish, which are translated texts, as well as original ones. The original Spanish texts which will surely appear

ga u raznim literarnim formama bilježi i to makar na papiru održava i čuva. [...] dala nam toliko živopisnih interesantnih jezičkih kombinacija, mnoge slike, metafore, silu izreka i poslovica [...]."

22 Serb.-Cr. "Konferencija sefardske omladine smatra špansko-jevrejski jezik, koji je još uvijek maternji jezik velikog dijela sefardskog jevrejstva, a ima i svoju istorijsku, kulturnu i nacionalnu vrijednost, sastavnim dijelom sefardske ideologije i važnim faktorom u sefardskom pokretu." 
with time and which are going to be widely read, will be cherished and promoted by the editors in a first place."23 ("Muestras publikasjones..." 1924: 2)

There were many types of Judeo-Spanish texts in the Bosnian Jewish press. They included some journalistic writing of social and political manifestos and programmes, for example those aiming at Zionist Sephardic Youth (I. Levi, Kamhi 1927: 2) or pre-electoral texts about the political condition of the Bosnian Sephardi minority ("Kon ožos avjertos" 1928: 1). Also cultural essays were printed, such as Kalmi Baruh's "Una nočada literaria" [Literary Evening], the text about Hayim Nachman Bialik and his poetry (Baruh 1925: 2).

Another category includes texts of Sephardi/Judeo-Spanish culture, like contemporary Judeo-Spanish prose and poetry by local but acclaimed Sephardi authors who appeared in Jevrejski život in the 1920s with their contribution to the Sephardi local cultural life. The weekly published: Laura Papo-Bohoreta, Avram Romano-Buki, Benjamin Pinto and others. ${ }^{24}$ As Muhamed Nezirović observed, the cooperation of the magazine with the local authors was in fact an ideological programme and it was a huge success. The authors were indeed widely read and a new local Sephardi literary activity started (see 1992: 556).

Also in the 1930s, every week Jevrejski glas in a section "Para noče de šabat" [For the Sabbath Evening] published short texts and anecdotes by other local authors hidden behind pseudonyms such as: Cadik, Unu di Bjelava, Miko, Lević, Josefiko, Jafi and Jakoviku. ${ }^{25}$ These texts only of amateurish character appeared as a result of a call of the weekly for every reader to create the content of the column:

"Starting from today, in every issue of our weekly we will present the events, anecdotes, dialogues, proverbs etc. from our life. With this we want to bring not only entertainment for our readers and make them laugh, but also we want to preserve in script the spirit

23 JSp. “La Redaksjon del „Jevrejski život” tomo una mueva dečizjon. Una novita, kuala en la sivtat de Sarajevo komo i en la Provinsja i espesjalmente de la Serbia del Sud mas ke seguro se va resivir kon la simpatia de parte de los meldadores del muestro organo: muestras publikasjones en espanjol, ke es trezlados i lavoros originales. Los originales de espanjol kualos seguro kon tempo van apareser i van estar bien meldados, la Redaksjon los va mas ke todo presiar i protežar."

24 See stories by Avram Romano-Buki, i.e.: "La možer mala" (1927: 5-6), "Muy lonđe" (1929: 2-4), Laura Papo Bohoreta, i.e.: "Madres" (1924: 3), Benjamin Pinto, i.e.: "Kol Nidre..." (1924: 4).

25 See short stories by Cadik, i.e: "Tija Lunača" (1931: 5), Miko, i.e.: "Las ebonoras de tija Bonača” (1931: 4), Josefiko, i.e.: "Tardi di vjarnis" (1931: 7), Jafi, i.e.: "La oja di tija Strulača" (1936: 4). 
of our maales (neighbourhoods), our language, our expressions and way of thinking, shortly speaking - our folklore. At the same time we call our readers to help us out with this goal." 26 ("Para noče de šabat" 1931: 7)

Apart from the column mentioned above, both magazines printed many samples of Sephardi folklore in regular columns, such as "El tesoro literario sefardi" [Literary Sephradi Treasure], "Romanse bosanskih Sefarada" [Romansas of the Bosnian Sephardim], "Sentensjas" [Sayings], "Palabras de savjos" [Words of Sages], "Španjolske izreke i poslovice" [Spanish Sayings and Proverbs] The editors also published texts from Judeo-Spanish folklore: romansas and kantikas, para-liturgical songs, proverbs and even Judeo-Spanish jokes in the column "Malo humora" [A Little Bit of Humour].

Like in the Jewish press in Germany Bosnian weeklies offered many translated texts. They published texts of non-Sephardi authors translated into JudeoSpanish, for instance works of famous Ashkenazi writers, including Isaac Leib Peretz, Sholem Aleichem or Hayim Nachman Bialik, as well as non-Jewish authors like the Serbian poet Jovan Jovanović Zmaj translated by Laura Papo Bohoreta. ${ }^{27}$

\section{Conclusion}

As the short overview of press materials indicates, both Yiddish and JudeoSpanish were important subjects of the discourse in the press. The main component of building the positive image and importance of both languages in the assimilated (or semi-assimilated) Jewish society was press information in the form of articles, reviews, informative notes on language or translations of literary texts. Everything was supplemented with readers' comments. The characteristic feature of the discourse in the press was that Yiddish and Judeo-Spanish were treated as the main elements of the Jewish identity.

26 JSp.: "De oj adelantre, en kada numero de nuestra gazeta vamos trajer akontesimientos, aneksotas, dialogos, proverbios etc. de nuestra vida. Kon esto no keremos azer solo pasatiempo a muestros lektores i daldes okazion para reir, sino konservar en eskrita el esperitu de muestras maales, muestra lingua, muestras ekspresiones i modo de pensar, en kurto dičo muestro folklor. En esteso tiempo jamamos a todos muestros lektores de ajudarmos en esto ečo".

27 See translated works by Isaac Leib Peretz, i.e.: "Los tres prezentes. La balansia de la žustisia" (1927: 2), Sholem Aleichem, i.e.: "Dos almas" (1927: 3), Hayim Nachman Bialik, i.e.: "Si tu keres konoser" (1926: 3), Jovan Jovanović Zmaj, i.e.: "Lem Edim" (1927: 2). 
Undoubtedly, we can observe a number of basic differences between these two kinds of sources: the presented Bosnian press (unlike the German press writing about Yiddish) was written and printed for those who still used the Diaspora language, in this case Judeo-Spanish. As far as the German press is concerned, the majority of readers did not speak Yiddish. This is the reason why we find Yiddish literary texts translated into German in the German press and, by contrast, Yiddish, German and other literary texts translated into Judeo-Spanish in the Bosnian press. For the same reason numerous articles on linguistic description of Yiddish in the German press are presented and at the same time, we can find very few essays on Judeo-Spanish. On the other hand, the Sephardi readers in Bosnia (unlike the Jews in Germany) were often encouraged to take an active part in the attempts at the cultivation of Judeo-Spanish language in the started process of decline. As for the German speaking readers of the press in Germany, the primary aim of the discourse in the press was that the Westjuden sensed the unity of Yiddish and general Jewish culture.

Nevertheless, some of the topics are common in both types of press - for instance a positive evaluation of the languages appeared in German and Bosnian magazines. Additionally, the attention was often focused on cultural and social events and organizations connected to Yiddish and Judeo-Spanish cultures as well as Yiddish/Judeo-Spanish folklore. Despite the fact that the presented press was published in different regions and was dedicated to different target readers, we can state that one could see a positive image of Yiddish in the press of assimilated Jews and of Judeo-Spanish in the press under the influence of the Sephardic Movement. A further comparative analysis of the status of both languages in the press discourse can be a fascinating and topic deserving more attention.

\section{References}

Abrevaya Stein, Sarah (2004): Making Jews Modern: The Yiddish and Ladino Press in the Russian and Ottoman Empires (The Modern Jewish Experience). Bloomington.

Acher, Mathias (1902): Hebraeisch und Juedisch. In: Ost und West. H. 4 (Juli). Berlin, 457- 464.

Acher, Mathias (1904): Das westjüdische Kulturproblem. In: Ost und West. H. 2 (Februar). Berlin, 73-88.

Acher, Mathias (1913): Noch einmal Ost- und Westjudentum. In: Die Freistatt. H. 5. Wien, 314-321.

A las komunidades sefardis en nuestros paizes! [To the Sephardi Communities in Our Country!] (1927). In: Jevrejski život 181, 2. 
Aleichem, Sholem (1927): Dos almas [Two Souls]. In: Jevrejski život 153, 3.

Anonym (1907): Juedischer Liederabned. In: Ost und West. H. 1 (Januar). Berlin, 71-72.

Aschheim, Steven (1982): Brothers and Strangers. The East European Jew in Germany and German Jewish Consciousness, 1800-1923. The University of Wisconsin Press, Wisconsin.

Attijas, Jakica (1927): Entre los Sefardin de la Srbija del Sud [Among the Sephardim in South Serbia]. In: Jevrejski život 138, 3.

Bar Ami (1905): Aus der jüdischen Sagen- und Märchenwelt. In: Ost und West. H. 2 (Februar). Berlin, 93-102.

Bar Ami (1907): Aus der jüdischen Sagen- und Märchenwelt. In: Ost und West. H. 1. (Januar). Berlin, 15-20.

Bar Ami (1914): Zur jüdischen Sprach-und Volkskunde. In: Ost und West. H. 8. (August). Berlin, 565-568.

Baruh, Kalmi (1925): Una nočada literaria [Literary Evening]. In: Jevrejski život 44, 2.

Berger, Julius (1916): Deutsche Juden und polnische Juden. In: Der Jude. H. 3 (Juni). Berlin, 137-149.

Bergmann, H. (1914): Unsere Stellung zum Jiddischen. In: Die Welt. H. 8 (Februar). Berlin, 177-179.

Bialik, Hayim Nachman (1926): Si tu keres konoser [If You Want to Know]. In: Jevrejski život 122, 3.

Birnbaum, Nathan (1913): Sprachadel. Zur jüdischen Sprachenfrage. In: Die Freistatt. H. 2. Wien, 83-88; H. 3, 137-145.

Birnbaum, Nathan (1916): Was sind die Ostjuden? Zur ersten Information. Wien.

Bitton, A. (1939): Španjolski jezik i Sefardi [Spanish Language and the Sephardim]. In: Jevrejski glas 47, 5.

Cadik (1931): Tija Lunača [Tija Lunača]. In: Jevrejski glas 50, 5.

Calvary, Moses (1916): Jiddisch. In: Der Jude. Heft. 1 (April). Berlin, 25-32.

Coralnik (1908): Die Sprachgesetzgeber von Czernowitz. In: Ost und West. H. 10 (Oktober). Berlin, 619-624.

Eliaschoff, J. (1901): Leon Perez. Ein moderner jüdischer Volksdichter. In: Ost und West. H. 4 (April). Berlin, 299-306.

Esperanzista (1924): Muestros academicos. „Esperanza” en Viena [Our academics. "Espransa" in Vienna]. In: Jevrejski život 35, 2.

Glavna skupština „La Benevolencije” [General Assembly of “La Benevolencia”] (1931). In: Jevrejski glas 21, 4. 
Herlitz, G./Kirchner, B. (Hg.) (1929): Jüdisches Lexikon: Ein enzyklopädisches Handbuch des jüdischen Wissens in vier Bänden. Berlin.

Jafi (1936): La oja di tija Strulača [Tija Strulača’s pot]. In: Jevrejski glas 3, 4.

Josefiko (1931): Tardi di vjarnis [Friday Afternoon]. In: Jevrejski glas 45, 7.

Kaufmann, Fritz (1916): Grenzsperre: ein Kapitel vom Versagen der deutschen Judäologie. In: Der Jude. H. 1 (April). Berlin, 13-22.

Kaznelson, Rachel (1923): Zwischen zwei Sprachen. In: Der Jude. H. 7-8. Berlin, 439-451.

Kon ožos avjertos [With Eyes Opened] (1928). In: Jevrejski glas 17-18 (67-68), 1.

Levi, Eliezer (1927a): Jevrejsko-španjolski na konferenciji [Judeo-Spanish on the Conference]. In: Jevrejski život 165, 1.

Levi, Eliezer (1927b): Jevrejsko-španjolski na konferenciji [Judeo-Spanish on the Conference]. In: Jevrejski život 166, 2.

Levi, Eliezer (1927c): Jevrejsko-španjolski na konferenciji [Judeo-Spanish on the Conference]. In: Jevrejski život 167, 2.

Levi Eliezer (1930): Kalmi Baruh. „El judeo-español de Bosnia”. In: Jevrejski glas 36-37, 8.

Levi, Isidor/Kamhi, Samuel (1927): A la žuventud sefardi [To the Sephardi Youth]. In: Jevrejski život 180, 2.

Lin, Josef (1907): Die ostjüdische Presse. In: Ost und West. H. 5 (Mai). Berlin, 318-322.

Lin, Josef (1909): Die hebräische und jargonische Presse im Jahre 1908. In: Ost und West. H. 4 (April). Berlin, 247-250.

Loker, Cvi (1997): Sarajevski spor i sefardski pokret u Jugoslaviji [Sarajevo Dispute and the Sephardic Movement in Yugoslavia]. In: Zbornik Jevrejskog istorijskog muzeja 7, 72- 78.

Maestro, Jakov (1929): Pabirci iz jevrejsko-španskog idioma [Trivia About Judeo-Spanish Idiom]. In: Jevrejski glas 34 (84), 6-7.

Meisl, Josef (1917): Graetz und das nationale Judentum. In: Der Jude. H. 7. Berlin, 471- 478 .

Miko (1931): Las ebonoras de tija Bonača [Good-byes of tija Bonača]. In: Jevrejski glas 46, 4.

Muestras publikasjones en espanjol [Our Publications in Spanish] (1924). In: Jevrejski život 28, 2.

Nadel, Arno (1916/1917): Jüdische Volkslieder. In: Der Jude. Berlin,112-122.

Nezirović, Muhamed (1992): Jevrejsko-španjolska književnost [Judeo-Spanish Literature]. Sarajevo. 
Nueva aktividad de "La Lira" [A New Activity of "La Lira"] (1932). In: Jevrejski glas 7, 7 .

Olszewska, Izabela/Twardowska, Aleksandra (2016), Yiddish and Judeo-Spanish as Determinants of Identity: As Illustrated in the Jewish Press of the First Half on the Twentieth Century. In: Colloquia Humanistica 5, 79-103.

Papo, Laura (1924): Madres [Mothers]. In: Jevrejski život 34, 3.

Paquet, Alfons (1916): Gedanken zum jetzigen Problem. In: Der Jude. H. 1 (April). Berlin, 23-25.

Para noče de šabat [For the Sabbath Night] (1931). In: Jevrejski glas 5 (42), 7.

Peretz, Isaac Leib (1927): Los tres prezentes. La balansia de la žustisia [The Three Present. The Balance of Justice]. In: Jevrejski život 145, 2.

Perles, F. (1925): Jüdisch-Deutsch und Jüdisch-Spanisch. In: Der Morgen. H. 1 (März). Berlin, 370-388.

Pinto, Benjamin (1924): Kol Nidre... [Kol Nidre...]. In: Jevrejski život 31, 4.

Pinto, Benjamin (1935): Nešta malo o literarnom stvaralaštvu kod nas [A Little Bit About Our Literary Work]. In: Jevrejski glas 42, 2-3.

Rappaport, Samuel (1917/1918): Aus dem religiösen Leben der Ostjuden. In: Der Jude. H. 5- 6. Berlin, 340-347.

Redaktion (1905): Zur jüdischen Volkskunde. In: Ost und West. H. 1 (Januar). Berlin, 1-3.

Rezolucije [Resolutions] (1927). In: Jevrejski život 169, 4.

Romano, Avram (1927): La možer mala [A Bad Woman]. In: Jevrejski život 173, 5-6.

Romano, Avram (1929): Muy lonđe [Very Far Away]. In: Jevrejski glas 34 (84), 3-5.

Schach, Fabius (1901): Der deutsch-juedische Jargon und seine Literatur. In: Ost und West. H. 3 (März). Berlin, 179-188.

Segel, B.W. (1901): Die Bernsteinische Bibliothek. In: Ost und West. H. 5 (Mai). Berlin, 357-360.

Večerina Tomaić, Jagoda (2016): Bohoreta. Najstarija kći [Bohoreta. The Eldest Daughter]. Zagreb.

Vidaković-Petrov, Krinka (1986): Kultura španskih Jevreja na Jugoslovenskom tlu [Culture of the Spanish Jews in the Territory of Yugoslavia]. Sarajevo.

Vidaković-Petrov, Krinka (2013): The Ashkenazi-Sephardi Dialogue in Yugoslavia 1918-1941. In: Kątny, Andrzej/Olszewska, Izabela/Twardowska, Aleksandra (eds.): Ashkenazim and Sephardim: A European Perspective. Frankfurt am Main, 19-39.

Zmaj, Jovan Jovanović (1927): Lem Edim [Lem Edim]. In: Jevrejski život 159, 2. 


\title{
Jonna Rock \\ Sarajevo Sephardim and Their Linguistic Identification $^{1}$
}

\begin{abstract}
The fall of the Ottoman Empire and the subsequent rise of national states in the Balkans led to an increase in exposure to Western-style modernization and ultimately to two World Wars. This article highlights issues pertaining to linguistic identification within the Sephardic community in Sarajevo today. The article recalls memories of Sarajevo Jews from the post-World War II Yugoslav state (1945-1992). The text clarifies which language the Sephardi Jews opted for after the Yugoslav experiment collapsed in the 1990s, a period that saw the beginning of the disintegration of Serbo-Croatian as a language, at least in a sociolinguistic sense. Moreover, this article explores the interviewees conceptions of Judeo-Spanish, the language that was spoken by Jews in Sarajevo until the Holocaust. The aim of the article is to analyze how ideological preconditions have affected identity formation as it expresses itself in linguistic behavior.
\end{abstract}

Keywords: Yugoslavia, Contemporary Sarajevo Sephardic Culture, Nationalistic language Ideology, Language Use

\section{Introduction and Empirical Analysis}

In this case study of the Sephardim in Sarajevo, I first elaborate on my empirical analysis, my methodology and the key research question. Thereafter I provide an historical context, and the relevance of the findings of this research. I then concentrate on the Jews in the second iteration of Yugoslavia and in present-day Sarajevo - followed by my empirical findings.

In terms of sources, apart from secondary literature, I conducted nine semi-structured interviews with Sarajevo Sephardim of different generations in April 2015 and in March 2016. Explaining my understanding of the deceptively straightforward term 'multigenerational' is only prudent. The philosopher Wilhelm Dilthey (1990: 37) maintains that a generation is a group of persons whose formative years have been shaped by same or similar major experiences, big changes and events. It is therefore not about one's age per se, but about the social experiences that are decisive for certain persons - for example, in the case

1 This work was supported by the Ernst Ludwig Ehrlich Scholarship Fund. 
of my subjects that these individuals have all lived in one or more different political systems that were or are in force within the territory of the former Yugoslavia. Of course, the individuals of a generation can hold different interpretations of the same experiences because they (the individuals) do not necessarily comprise a homogenous group.

The analysis of my interviews is not about objective 'facts'- which in turn are also more or less constructed - but rather about memory and the role of memory in creating meaning (cf. Zahavi 2003: 9, 42). In this connection, the philosopher Paul Ricoeur (1985) writes that it is by constructing narratives that people contribute to a process of culture building and that by the same token a personal identity is a 'narrative' of the self. I interpret perceptions of identity from a phenomenological viewpoint and the goal is for me to narrate about how my interview subjects actually conceive of the world around them, rather than interpolating their experience from ready-made theories, in order to produce new knowledge. Writing about national identity practices among Jews living in Germany today, the sociologist Judith Gerson (2001: 180) asks in what way do people experience identity formation. This question may imply that we are constructing cultural patterns independently. With hindsight, however, we know that values can be constructed by 'others' and therefore imposed upon the individual's process of self-formation.

Needless to say, I can describe an identity conception of my informant but I cannot know how it comes that his/her conception is what it is, in other words, I cannot reconstruct - at least not fully - the motivation(s) behind his/her behavior. Nevertheless I endeavor to map both spoken and unspoken parameters for identity conceptions that frame interviewees' narratives. The reason for this is to identify any latent content of the statements whenever possible, and to demonstrate the general as well as the specific structure of the subjects' conceptions of identity.

\section{Methodology and Research Question}

I have chosen a qualitative approach anchored in the method of participant observation to be able to grasp more fully wide spectrum of identity conceptions among my subjects. My search for interviewees began when I contacted the Sarajevo Jewish Community Centre - specifically its president, Jakob Finci, and its non-residential rabbi, Eliezer Papo, in 2013. I am aware that because I sought informants through a Jewish institution, they would most probably identify as Jews. Still, I want to find out how such interviewees understand 
Jewish identification. Moreover, I do not assume that because such subjects have Jewish roots, they affirm Jewish identity a priori. My attitude towards the interview situation was characterized by openness and flexibility. I did not anticipate any particular research results and did not direct the informants to select or otherwise furnish ready-made answers. I conducted the interviews in Bosnian with the use of video camera or iPhone. A local translator and two cameramen assisted me during the interviews. When I needed clarification, I communicated with the interviewees in English. One of my interlocutors, Yehuda Kolonomos, had lived in Oslo, Norway for 12 years so he spoke Norwegian and I Swedish (my mother tongue). I informed all interviewees about the research and its objectives, and they freely decided whether they wanted to participate. Nowadays, Judeo-Spanish is hardly spoken among Sarajevo Jews, which is why the interviews were not conducted in Judeo-Spanish.

With regard to the reference group in Sarajevo, I assume that because of the early immigration from Spain took place long ago, in the wake of 1492, the first language of my subjects is Serbo-Croatian or another ex-Serbo-Croatian language and not Castilian or some other Iberian language, I also suppose that the issue of language choice became vital for my subjects when Yugoslavia disintegrated in the 1990s and establishing one's relationship to the emergent postYugoslav polities became imperative. The Sephardim, who had been classified as Yugoslavs in Yugoslavia, had to build a new identity from predetermined labels and categorizations that the successor states presented to them. I therefore asked my interviewees:

What language do they choose - considering the fact that they do not follow the usual language division between Orthodox Christians (who often speak Serbian), Catholics (Croatian), and Muslims (Bosnian)?

Underlying this question is my suspicion that an individual's language choice is most likely a core element in his or her identity creation, and is presumably linked to the subject's notions of what it means to be both the member of a religious and ethnic minority as well as a citizen alongside members of the ethnic and religious majorities.

Moreover, the Sarajevo Sephardim have long reflected the complex relationship between language, religion and ethnicities in their own loyalties. Therefore, they seem to be uniquely positioned to analyze the contemporary language situation in Bosnia-Herzegovina, where the three highly intercomprehensible varieties of a single regional language has transformed into three distinct national standards (Bosnian, Croatian and Serbian). 


\section{A Historical Overview}

In 1492, the Catholic Monarchs, Ferdinand and Isabella forced Sephardic Jews to either convert to Christianity or to leave Spain. The expulsion in Spain resulted in some $60,000^{2}$ Sephardim moving to the Ottoman Empire - especially to Constantinople and Salonica. By the second half of the 16th century, they started to migrate to northern parts of the Ottoman Empire, i.e., to for instance cities like Belgrade, Bitola, Sarajevo and Sofia (see Benbassa/Rodrigue 2000: 7-10; Kerkkänen 2001: 24). The Sephardim brought with them the Romance languages that they had spoken in Spain before their expulsion. In their new, exilic environments, this language developed into Judeo-Spanish (see Astrologo-Fonzi 1992: 128).

The Ottoman Empire did not fall until after the World War I when the Turkish Republic was established. In 1878 Sarajevo and Bosnia-Herzegovina still remained nominally Ottoman, but under the terms of the Congress of Berlin, Bosnia and Herzegovina was occupied by Austria-Hungary (which in 1908 annexed the province, thus de jure ending the Ottoman rule). During the AustroHungarian occupation from 1878 to 1918, Ashkenazi Jews emigrated, although to a lesser extent than the Sephardim. Under Austria-Hungary, many Sephardim underwent a period of westernization with the standardization of education through the Alliance Israélite Universelle. ${ }^{3}$ However, this process did not benefit the population equally, since there was no Alliance school in Sarajevo, as well as other places (see Kerenji 2008: 32-33).

Moreover, the majority of the Sephardic elite in Austria-Hungary sent their children to study in $\mathrm{f}$. e. Vienna. The westernization of life during this time also prompted the Sephardic communities to switch to the majority national languages and/or to French (also because of the influence of the Alliance Israélite Universelle in some centers), which contributed to that Judeo-Spanish being spoken less. In Bosnia German was introduced in Jewish schools along with Serbo-Croatian so that the shift to a state school would be easier (see Benbassa/ Rodrigue 2000: 91, 151).

2 According to other sources more than 100,000 Sephardim came to the Ottoman Empire, i.e., between 100,000 and 200,000 (Birri-Tomovska 2012: 35).

3 The Alliance Israélite Universelle was a Paris-based Jewish organization founded in 1860. One of the missions of the organization was to promote a more advanced and Westernized Jewish educational system with French as the language of instruction (Birri-Tomovska 2012: 89, 152). 
Ashkenazi Jews in Zagreb promoted the Yugoslav Zionist movement after World War I. They had been educated in the West, in Berlin and Vienna, and imported Zionist ideology into Yugoslavia in order to respond to growing antisemitism in Europe (see Birri-Tomovska 2012: 163). Zionism was essential in uniting the Ashkenazi and Sephardic Jews of Yugoslavia. Nevertheless, only $1.5 \%$ of Yugoslav Jewry had left for Palestine by the time of World War II (see Kerkkänen 2001: 23, 27). The reason why so few Jews emigrated to Palestine was possibly because they were treated well in Yugoslavia. Immigration to Palestine increased during the 1930s, but it was only in 1940 that the first anti-Jewish laws were adopted (see Birri-Tomovska 2012: $163,169)$.

During World War II, Germans and their Slavic collaborators killed more than $80 \%$ of Yugoslav Jews, some 82,500 persons. Before the war, the Jewish community of Sarajevo had 10,000 Jewish members, $10 \%$ of the city's total population. Only 1,400 Jews survived the war (see Greble 2011: 12).

After the World War II, six major aliyot took place between 1948 and 1952. After the first two aliyot, Yugoslav Jewry had already been reduced by $60 \%$. On emigrating to Israel, Yugoslav Jews lost their property ownership rights. However, many Yugoslav immigrants were not happy with their lives in Israel and decided to return to Yugoslavia (see Ivanković 2011: 150).

\section{State of the Art}

A great deal of research on the Sephardim has dealt with linguistic aspects, more precisely with Judeo-Spanish, that some Sephardi communities preserve until today. Among the many topics that have been explored are phenomena of language contact, language mixing as well as attrition and obsolescence (see Astrologo-Fonzi 1992; Shewmon Seitz 2008). In the present study of the Sarajevo Sephardim I shift the focus from the dominant research paradigm (i.e., Romance Studies and contact linguistics) to the linguistic and sociolinguistic status of former Serbo-Croatian.

Questions of linguistic and ethnic identity formation in European minority groups have been studied in different settings. In this section, I will present a few illustrative cases drawn from several recent studies in order to shed light on the related phenomena that I explore among Sarajevo Jews of loyalty towards the

4 When one immigrates to Israel it is termed to go on aliyah from the so called diaspora to Israel. 
'mother tongue ${ }^{5}$, 'vitality', and 'revival'. The role of a 'linguistic nationalism ideology'8 is central in all cases as national preconditions clearly affect the linguistic identity formation.

The shift in language from Arvanítika to the national Greek language was based, among other things, on the widely-held cultural assumption that Greek is the power code and that non-standardized and oral Arvanítika is no longer a pure but rather a bastardized language (see Tsitsipis 1998: 18, 120, 122). In her classic work on language death, the linguist Nancy Dorian Dorian (1981:4) focuses on the fisher-folk's East Sutherland dialect of Scottish Gaelic having English as its 'competitor', i.e. a language of wider currency. This case resembles the previous in the way that it highlights a generational language shift from the low status Gaelic to the high status English (see Dorian 1981: 40).

Le Page/Tabouret-Keller (1985: 5) highlight three shared characteristics of the many different Caribbean communities and their descendants in London. Firstly, the vernacular of these groups is stigmatized in relation to the majority language. Secondly the group members' language use is unpredictable and thus different from that of the monolingual speakers; and thirdly, the linguistic standards of the Caribbeans and their progeny are 'in the making,' and therefore controversial. The result of these dynamics is a generational split: the elderly tend to be linguistic nationalists whereas the younger generation relies on other categories (Creole, Mixed and Belizien) (see Le Page/Tabouret-Keller 1985: 220-221).

5 The generally accepted definition of the mother tongue - i.e. the language spoken in an individual's home - is obviously not always accurate (since the language spoken at home not always is the first one) and this is why first and second languages might be preferable.

6 With a loyalty towards the 'mother tongue', I have the liveliness of the mother language in mind, i.e. the level of spokenness and various generations' different competencies. The first time I heard Michael Studemund-Halévy speak about Sephardi and Ashkenazi culture (Wrocław, 09.05.2016) he quoted sentences from Isaac Bashevis Singer's speech at the Nobel Banquet, December 10, 1978: "Yiddish may be a dying language but it is the only language I know well. Yiddish is my mother language and a mother is never really dead". In this article, I approach the concept of the vitality of a mother language with a similar attitude, i.e. that the dying of a mother language is a long and transformative process and not the same as a language that no longer exists.

7 A revitalization of a language is typically a process that aims to rescue a dying language as in the case of Welsh.

8 A 'linguistic nationalistic ideology' represents a meeting point of nationalism and language, wherein nationalistic ideology is formed by language (Stukenbrock 2005: 35). 
According to the political scientist Burcu Ellis (2003: 2, 4--5), the ŞehirliOttoman way of living was a unique and alternative situation where identity formation is not reducible to the assertion of any minority element (the Albanian or the Turk). The author describes how multiple Muslim identities face a challenge from the growth of nationalism, since these identities were not primarily national, and nationalism dictates that the national identity, one associated with the Christian majority, be manifested and valued above all others (see Ellis 2003: 89).

In light of the cases I have discussed above, my hypothesis with regard to linguistic choice in ethnic identity formation is the following: despite a shift to a second language, the first language is not necessarily dead but takes a new form related to self-identification and to the politics of ethnicity. In the context of my case study of the Sephardim, this transformation, can be explicit by the fact that the reference group may refer to its (second) language as 'our language' in opposition to the government-furnished, formal language classification that is at hand.

\section{The Jews in the Second Yugoslavia (1945-1992)}

In Tito's Yugoslavia (1945-1992), the Federation of Jewish Religious Communities in Yugoslavia - a group of 42 Jewish communities - was re-established in 1945 (see Kerkkänen 2001: 42). ${ }^{9}$ More than 90 \% of married Jews in Yugoslavia were parties to mixed marriages between Jews and non-Jews (see Kerkkänen 2001: 169), and after World War II intermarriages between Sephardim and Ashkenazim were also common (whereas before the war intermarriages between Sephardim and Ashkenazim were rare) (see Birri-Tomovska 2012: 183, 187). To be sure, Kerkkänen (2001:49) maintains that intermarriages between Sephardim and Ashkenazim, were unusual even after the war, and that it was only the earlier,

9 In the second Yugoslavia's constitution, there were two official categories of nationality: narod and narodnost. In the constitutions of the federal republics there was another category: etničke zajednice. Narod were people from one of the Yugoslavian republics, i.e. Croats, Macedonians, Montenegrins, Muslims, Serbs and Slovenes. Serbs and Croats had two homelands in Serbia/Croatia and in Bosnia. Narodnost were national minorities whose 'home' was situated outside of Yugoslavia, the largest being Albanians and Hungarians (see Ellis 2003: 69). Etničke zajednice were those groups of people considered geographically scattered, i.e. Jews, Greeks, Russians and others (Blum 2002: 29). The categories of nationality attributed to these groups were, however, shifting and the Romani people were recognized as a narodnost in 1981 both in the Bosnian, Croatian and Montenegrin republics (Matasović 1989: 119). 
official distinction between the two ethnic communities that Yugoslavia's Jews discontinued after 1945.

Almost all Yugoslav Jews lived in urban centers (as in Belgrade, Sarajevo and Zagreb). Less than $5 \%$ lived in rural areas where organized communities did not exist (see Birri-Tomovska 2012: 149). Because of their concentration in the big cities, most Jews were active in trade and banking rather than in agriculture (see Birri-Tomovska 2012: 148; Ivanković 2011: 132). Additionally, regime-loyal Jews held high positions in the state-administration, as diplomats and in the army (see Kerkkänen 2001: 98). Tito's right-hand man, Moša Pijade, who was Jewish, came to function as a middleman between Jews and Yugoslav authorities. Pijade was engaged in migration issues and ensured that it became easier to migrate from Yugoslavia than it was from Eastern European countries (see Hofmeisterová 2016: 270; Kerkkänen 2001: 100). According to Ivanković (2011: 134), the Yugoslav authorities were supportive of Zionism. After the foundation of the Israeli state, Yugoslavia was one of the first countries to officially recognize Israel (see Ivanković 2011: 150).

It should be noted, too, that discussions were ongoing whether the Yugoslav Jewish federation should be considered ethnic or religious (see Hofmeisterová 2016: 271-272, 275; Ivanković 2011: 134). These debates prompted the government to issue a new law on the legal status of religious communities in 1953. It granted the right to conduct religious activities but political activities by religious communities were not allowed. Consequently, the Jewish Federation's collaboration with Israel was suddenly problematic (see Kerkkänen 2001: 89). In the same year, the Communist Party also promulgated a new law emphasizing that atheism was one of its basic principles. This meant, of course, that one could not be a member of a religious organization and the Communist Party at the same time. In order to get around this problem, the Jewish Federation deleted the word religious and renamed its Jewish constituency as a national minority instead. A separate religious section of the Federation was founded that came under the law on religion. Moreover, the new atheist principle of the Communist Party - stated as anti-religious clause introduced in the constitution - pushed Jewish members of the party to boycott Jewish holidays (see Hofmeisterová 2016: 278). According to Ivanković (2011: 144) however, religious activities (such as the services in the synagogue) were never explicitly discouraged. Although, in reality religious practice was considered taboo and as a result many Orthodox Jews migrated to Israel (see Ivanković 2011: 143; Kerkkänen 2001: 69).

On one hand, one could argue that Jews were treated well in the second iteration of the Yugoslavian state, by the mere fact that they were equal to others by law; in other words, Jews did not have any special status or constitute a group set apart in 
order to be protected (i.e., by being recognized as an official minority with special governmental support). As the political scientist Dejan Jović (2011:122) writes: "The Yugoslav system was based on the idea that nobody could be treated as a minority, but as equal to the majority" (Jović 2011: 122). On the other hand, one may argue on the basis of the large numbers of Jews who decided to leave the country and undertake aliyah from the 1940s to the 1960s, that the second Yugoslavia in fact did not present such good conditions for Yugoslav Jews (see Ivanković 2011: 150).

\section{The Jews in Sarajevo Today}

During the siege of Sarajevo, which lasted throughout the 1992-1995 war in Bosnia, the Sarajevo Jewish Community organized eight convoys for people to leave the city. The organizers were very welcoming to every person who wanted to leave, regardless of his or her religion. During the Yugoslav wars of the 1990s, a majority of Yugoslav Jewish Community members fled to Israel as well as to other countries (e.g. Canada, Spain, Switzerland, United Kingdom). The evacuation was financed by the American Jewish Joint Distribution Committee (Kerkkänen 2001: 177; Kerenji 2017: 246). ${ }^{10}$ When the war in Bosnia ended in November 1995 (this was when the Dayton peace agreement was reached) many Bosnian Jews who had fled to Israel returned to Sarajevo. They were often highly educated, though often could not find work in Israel. Moreover, it was expensive to live there, and many of them still had apartments in Sarajevo to which they could return. ${ }^{11}$

After the Yugoslav wars, the Yugoslav Jewish confederation emerged as five separate entities in Croatia (approximately 1,700 community members), Serbia (approximately 3,200 community members), Bosnia-Herzegovina (approximately 1,000 community members), Slovenia (approximately $100 \mathrm{commu}$ nity members) and Macedonia (approximately 200 community members). In Montenegro, there were only 25 Jews. They were registered in Belgrade's Jewish Community (Kerkkänen 2001: 186). From 2012 on, there has been an independent Jewish community in Montenegro with around 100 members.

The Jews in Bosnia-Herzegovina, as well as other small minorities in the country, faced the special situation of having three major ethnic groups dominating the country: Muslims, Serbs and Croats. In Sarajevo however in 2003, Muslims constituted $80.5 \%$ of the city's total population, the Serbs constituted $7.5 \%$ and the Croats $12 \%$ (Sundhaussen 2014: 352). Therefore, Serbs and Croats

10 The information was also confirmed by Eli Tauber from the Institute for Researching Crimes Against Humanity during the interview with him on the 4th of April 2017.

11 The information was given by Jakob Finci on the 12th of December 2016. 
were (and remain) clearly minorities in Sarajevo, at least in terms of numbers, too. The Muslims, Serbs and Croats are however recognized as the constituent peoples of Bosnia and Herzegovina whereas Jews and other official minorities are 'Others'. Post-Yugoslavia it was impossible for Jews to continue declaring themselves 'Yugoslavs'. According to the political scientist Ari Kerkkänen (2001: 194), Jews' identification either with only one of the post-Yugoslav constituent Muslim, Serb or Croat peoples was not an interesting option. Thus, after the fall of Communism in the 1990s, according to Kerkkänen (2001: 109), young Jews started to declare themselves Jews. ${ }^{12}$

According to the 2016 Bosnian Questionnaire - that is requested by the European Commission to the Council of Ministers of Bosnia and Herzegovina for the preparation of the Opinion on the application of Bosnia Herzegovina for membership of the European Union - information from the State Council for National Minorities in Bosnia must be provided regarding the number of people belonging to minority groups according to the latest census in 2013. Only recently has the number been made public. There were 282 declared Jews. The paradox of this outcome of the survey is that the organized Jewish Community of Bosnia and Herzegovina has 880 members in total. ${ }^{13}$ Jakob Finci, in his personal statement, comments in this regard:

"We have a list of Jewish Community members in all six communities in Bosnia. All together we are around 880 people. Even nowadays [like in former Yugoslavia when Jews declared themselves Yugoslavs] Jews hide that they are Jewish. On the 2013' census, we were 282 Jews - because why be a minority if you can be the majority? Especially, having in mind, that everything here is divided into the three ethnic groups [Bosnians, Croats and Serbs]. You can hardly reach any position in the government, in the economy and so forth, if you say you belong to a minority."

Currently, there is no law on Return of Property in Bosnia and Herzegovina. Finci thinks the Bosnian government should follow the example of Serbia by adopting such a law. ${ }^{14}$ Since 2006, the Serbian law, requires that the Serbian

12 According to the 1995 Constitution of Bosnia and Herzegovina, there is a distinction between the three "constituent Bosniac (Bošnjaci), Serb, and Croat peoples' and the 'others'”. The 'others' are members of ethnic minorities and persons who do not declare affiliation with any particular group. As a matter of fact, only persons declaring affiliation with a 'constituent people' are entitled to run for the House of Peoples and the Presidency. Bosnia and Herzegovina cannot be a candidate for the membership of the European Union until the constitution is amended.

13 The information was given by Jakob Finci on the 6th of June 2017.

14 The information was given by Jakob Finci on the 12th of December 2016. 
government gives the Belgrade Jewish Community 950.000 Euro every year (with the first installment in 2017) as compensation for the Community's property-losses during World War II (cf. Ivanković 2009: 73).

There are no Jewish day schools and kindergartens and therefore it is the private educational and recreational activities organized by the official Jewish Community in Sarajevo, all of them extracurricular, that function as a Sephardic hub. ${ }^{15}$ "La Benevolencia"16 in Sarajevo of today is a non-governmental organization based in the same premises as the Jewish Community and which is operating in close cooperation with the Jewish Community. One of "La Benevolencias" humanitarian projects is to provide support to Bosnian Holocaust survivors.

\section{The Second Yugoslavia and Linguistic Sephardic Identification in Sarajevo Today}

I posed pre-formulated questions to my interviewees, but also asked relevant follow up questions that were spontaneous. In this way, the pre-formulated questions served more as an initial basis for discussion and a way for my interviewees to freely elaborate on them, rather than as strict boundaries of the responses. The interviewees belong to three generations. First, there are those who had lived in Yugoslavia and had lived most of their lives there. Secondly, I spoke to people who had lived in both Yugoslavia and Bosnia and, finally, to people who had lived only in Bosnia. I conducted most interviews at the Sarajevo Jewish Community facilities or at the Viennese Café in Hotel Evropa, also in Sarajevo. I spoke to three Community members under the age of 30 . One of these, Tea Abinun, was born in Sarajevo in 1998 and is a M.A. student in music in Sarajevo. She can speak English, Bosnian-Serbian-Croatian-Montenegrin and a little Spanish. She has no self-reported connection to Israel. In the latest census in 2013, she declared herself as Jewish in terms of both religion and ethnicity, and that her mother tongue is Bosnian.

My second source, Vladimir Andrle, was born in Sarajevo in 1986 and is a coordinator of humanitarian and cultural activities; he has completed a B.A. degree in music in Sarajevo. He speaks English, Bosnian-Serbian-CroatianMontenegrin and a little German and Spanish. He has been to Israel once in his life for a weeklong leadership-program. In the latest census in 2013, he declared

15 The information was given by Jakob Finci on the 6th of January 2017.

16 The educational, cultural and humanitarian association "La Benevolencia" was established in 1892 by well situated Sarajevo Jews who wanted to support talented students who were not able to afford their studies. 
himself as Jewish in terms of both religion and ethnicity and that his mother tongue is Bosnian.

My third source, A.A., did not wish to be named. She was born in Sarajevo in 1994, and is a M.A. student of musicology in Sarajevo. She can speak English, Bosnian-Serbian-Croatian, and has no self-reported connection to Israel. In the 2013 census, she declared herself as Jewish by religion and Croatian by ethnicity, and noted that her mother tongue is Bosnian.

All families of my three sources from this generation lost property during World War II that was never returned to them or compensated for. Statements from this generation younger than 30 years old show that they are amused when they speak about the emerged national languages. It seems in this meta-lingual way that they have developed transnational or translingual views on the national language (i.e. their mother language). Tea Abinun expresses the following:

\footnotetext{
"My parents are nostalgic. They wish Tito would still be alive. According to them the times were better then [...] And they still call themselves Yugoslavs. Of course, they also identify as Bosnian and Herzegovinians but in a broader sense they are still Yugoslavians. Our parents spoke Serbo-Croatian with us and they still call their language SerboCroatian but we say Bosnian, or Bosnian-Serbian-Croatian [Laugh]."
}

This girl from the younger generation says she speaks 'Bosnian' or 'BosnianSerbian-Croatian' because she was raised in the new Sarajevo. However, at the same time she laughs when she talks about the new language-classifications. Her attitude, to my mind, reflects identity perceptions 'beyond the Sephardic community' meaning, that she is willing to look in- and outside of the community to construct her concept of a linguistic identity. This is of course novel that this younger generation can choose a language or choose to laugh whereas their parents did not have any choice and automatically spoke Serbo-Croatian in its Bosnian-Herzegovinian sub-variant. A.A. from this same generation expresses:

"It's funny to me because you don't know what language you're actually talking. My parents ironically say: 'Bosnian' what should that be? It's Serbo-Croatian! They're confusing me with all this. But logically: If I live in Bosnia, I speak Bosnian."

Again, data from this generation younger than 30 years old show that the Sephardim have internalized the official national Bosnian language-classification. When discussing the significance of language more broadly, Vladimir Andrle is giving voice to his powerlessness in relation to Ladino-maintenance, i.e. regarding the ability to learn Judeo-Spanish since opportunities do not exist. At the same time, there is also a lack of interest among the younger generations for the Sephardic language, since it has no function in the society: 
(Vladimir Andrle) "Very, very few people. I think that there are only two or three elderly people in Bosnia who speak Ladino, and I also think that this language will become extinct in Bosnia."

The same person clarified in a Facebook-message on another occasion (201504-05) under what premises Spanish, not Judeo-Spanish, was taught in the Sarajevan Jewish Community:

"We were 8 people aged 22-50 years old that attended a Spanish course at the Jewish community. It was between November 2013 and July 2014 but the group fell apart so we couldn't continue."

Tea Abinun comments:

"My grandfather spoke Ladino and of course we must work for the preservation of Ladino, but nobody speaks it and it's impossible to study Ladino."

According to this youngest generation there is moreover a need for separation between the other groups of people. The Bosnian language politics reflects this need. At the same time, A.A. expresses a wish not to hurt anyone or to point the Muslim influence and dominance in the Bosnian language out:

(Tea Abinun) "Shmahala instead of mahala [...] There is a need of separation for peoples and their languages and yes, yes, yes, certainly an Islamization is taking place in the Bosnian language!"

(A.A.) "I would not call it an Islamization just because more Turkish originated words are coming up. I think Bosnian has always had these words. People coming from outside Sarajevo, from Mostar and other places come with an accent and a different mentality. Anyway, it doesn't sound nice to say that Bosnian is Islamized or to point at this. Actually, in Serbian there is also many Turkish words."

(Vladimir Andrle) "Croats and Serbs in Bosnia-Herzegovina are neglecting the existence of the Bosnian language, politicians, even ordinary people. Bosnia-Herzegovina exists now as an independent country so why wouldn't we have the Bosnian language as well?"

My interviewees between the ages of 30 and 55 appeared to demonstrate a more ambiguous relationship towards the mother tongue. Yehuda Kolonomos was born in Sarajevo in 1968 and is a university lecturer who has completed a M.A. degree in music in Oslo. He speaks English, Croatian, Macedonian, Norwegian, Swedish, Danish, Italian, Hebrew and Ladino. He has been in Israel a few times as a tourist. In the future, he would like to do aliyah and settle down in Israel. In the latest census in 2013, he declared himself as Jewish in terms of both religion and ethnicity and that his mother tongue is Croatian.

Igor Kožemjakin was born in Sarajevo in 1980, and is a counselor whose work involves ethnic-religious cooperation. He has completed one year of Jewish 
Studies in Stockholm and has also studied law and economics in Sarajevo. He speaks English, Russian, Hebrew, Bosnian-Croatian-Serbian-Montenegrin, Bulgarian and Macedonian. He made aliyah in 1994 and returned to Sarajevo 2001. In the latest census in 2013, he declared himself as Jewish in terms of both religion and ethnicity and that his mother tongues are Bosnian, Serbian and Croatian.

Tina Tauber was born in Sarajevo in 1982 and works as a tour guide. She completed one year of Jewish Studies in Stockholm and has studied English in Sarajevo. She speaks Hebrew, English, the Yugoslavian languages, and a little Russian. She made aliyah in 1992 and returned to Sarajevo in 2004. In the census in 2013, she described herself as Jewish by religion, Bosnian by ethnicity and that her mother tongues are Bosnian, Serbian and Croatian.

All my sources from this demographic bracket lost property during and after World War II that was never returned to them nor did they receive compensation.

Igor Kožemjakin makes preference to a Jewish experience in Yugoslavia and also a multifaceted relationship towards the mother tongue:

"My parents were really positive towards Yugoslavia. Life was easier with more social security. I was a pioneer. We were Yugoslavs with a Jewish background and we celebrated Jewish holidays at home. It's difficult today to talk about a mother tongue [...] Judeo-Spanish ${ }^{17}$ was spoken at home when I was a child, not Ladino. My [...] very difficult question, knowing the fact that there have been linguistic disputes. I don't know how to call it anymore [...] 'mother language'. So, I speak Bosnian/Croatian/Serbian. I really don't know how to [...] Sarajevski (the 'Sarajevo language') would be the most appropriate name. Sarajevski."

"For us it's the question of how to call it. So we often call it the way the person we're talking to is calling it. For me it's one language but I would try to speak "our language". That's how I ask at the airport if I hear someone speak my language: Vi govorite naš jezik? [Do you speak our language?]."

"I am not a speaker of Ladino, unfortunately it's a language which is falling out of use. Here in Sarajevo in particular this was a community where Ladino was spoken at homes, until the World War II. For example, my grandmother didn't speak our language well enough, because her native language was 'Djudeo-Espanjol' Judeo-Spanish.”

17 Ladino has traditionally been characterized as the written language of Eastern Sephardim, and Judeo-Spanish the name of the spoken lingua franca. Nevertheless, in the interviews the reference group is not holding on to these traditional classifications but they use Ladino as a term for the spoken language, too. 


\section{Yehuda Kolonomos contemplates upon Yugoslavia:}

"Because we Jews were living in Yugoslavia relatively free, nobody persecuted us because of our religious beliefs. Some religious communities did go through persecution, but we didn't, ever. Yugoslavia was a country created on the basis of respect for the freedom of religion, at least nominally.

I was raised in a sort of a mixed marriage, where my mother was, let's say, relatively neutral to the regime, and my father, being a Croat, didn't think highly of it because of our property was nationalized after the World War II, so [...]"

When speaking of the mother tongue he reflects:

"Croats in Bosnia and Herzegovina today claim that they speak the Croatian language, Serbs say that they speak Serbian and Bosniaks Bosnian. What happened there was a political division, which is clear to us locals, and maybe not so clear to foreigners. But all of us basically speak the same language. I don't think there's any difference but, of course, due to political reasons, and as someone coming from a Croat area, where Croats live, and where all of my neighbors and people around me say that they speak Croatian, I also belong to that $[. .$.$] environment.$

I didn't use Ladino in real life, I understood a lot, almost all of it, and I know a lot of songs in Ladino which I learned when I was a child. But very few people use Ladino for speaking, so [...] Even those of us who live in our Jewish community and who can speak Ladino almost never use it to talk with each other."

Tina Tauber thinks about the current language situation in Bosnia:

"Every day we learn a new word. I think we are going backwards. We talk like we used to talk and we're going backwards in all aspects mentally [...] Back to the Ottoman Empire, maybe later."

Other impressions of the language situation from this generation are the following:

“(Igor Kožemjakin) Lahko, mehko [instead of lako, meko] [...] I have no problem with this, the important thing is to understand each other. There are archaisms in Bosnian coming up. This wish and right to be a specific group is also related to the language [...] For me personally all three languages are one.

(Yehuda Kolonomos) I would rather call it individualization than islamization. Turkish people is a narod and not necessarily Islamic. I think it's a political rather than religious process."

Additionally, I spoke with three persons older than 55, who are members of the "Bohorete Women's Club"18. One of them was Matilda Finci, who was born in

18 The "Bohorete Women's Club" consists of approximately 20 members who meet once a week, on Tuesdays, in the facilities of the Jewish community to discuss current 
Sarajevo in 1935 and she studied Romance Languages (French, Italian and Latin) in Sarajevo. In addition to Serbo-Croatian, she speaks French, Italian, Russian, Hebrew and a little Spanish and Ladino. She lived in Israel during the war from 1992 to 1999. In the latest census in 2013, she declared herself as Jewish in terms of both religion and ethnicity and stated that her mother tongue was SerboCroatian (this was not a given option, but she asked the person asking the questions to write Serbo-Croatian anyway). She lost property in 1948 that was never returned or given compensation for.

My second source, Erna Kaveson Debevec, was born in Sarajevo in 1933 and she studied law in Sarajevo. In addition to Bosnian, she speaks English, Spanish and Ladino. She has never lived in Israel, but has family there. In the latest census in 2013, she declared herself as Jewish in terms of both religion and ethnicity and that her mother tongue is Bosnian. During the communist regime, her family lost property that was never returned or given compensation for. The state has recently sold her former property to a private person.

Finally, Laura Papo Ostojić, was born in Sarajevo in 1939 and studied architecture in Sarajevo. In addition to Serbo-Croatian, she speaks English as well, as a little French and Italian. She has been to Israel once to visit her two sons who lived there during the Bosnian war but who have come back to Sarajevo after the war. In the 2013 census, she declared herself as Jewish by religion and ethnicity and that her mother tongue is Serbo-Croatian. (This was not a given option but she asked the person asking the questions to write Serbo-Croatian anyway). Laura Papo Ostojić lost property in 1948. The property was never returned and she did not receive compensation.

Matilda Finci has the following perception:

"It was very positive in Yugoslavia. I saw Tito once outside Hotel Evropa. Socialism is a better system. We were all Yugoslavs. It was good because we all spoke the same language. I taught Serbo-Croatian [...]

Let me tell you an anecdote: My mom went to the market and bought [...] as she said: 'I've bought Serbian cheese to make a pie'. And my daughter said: 'Granny, it's not Serbian, you should say Serbo-Croatian' because it was the name of the language."

On the other hand, the same person says:

"I still regret that I didn't learn the language from my mother and my stepfather who spoke Ladino Spanish at home. And I didn't think that was something important. Can

happenings and to socialize with each other. The name of the club refers to Luna (Laura) Papo Bohoreta (1891-1942), who was a very productive Sarajevo-born feminist writer and playwright. She wrote her works in Judeo-Spanish and cared deeply about preserving the Sephardic culture. 
you imagine that I didn't know, I was a child back then, I had no idea it was Spanish. I was thinking - God, how can they speak in this way in front of me, when they don't want me to hear something? They spoke Ladino at the time.

The important thing is to maintain the tradition and to maintain Ladino, that really valuable language. I mean, there are so many sayings, so much wisdom, so many [...] well $[\ldots]$ it's the linguistic culture $[\ldots]$ "

\section{Erna Kaveson Debevec expresses:}

"In socialist Yugoslavia we spoke Serbo-Croatian, went to school and learned that language, naturally, and spoke it while communicating with friends. But for traditional purposes, let's say prayers, or anything like that, we either used Hebrew, or Ladino, 'Djudeo-Espanjol', because there are some prayers which have been translated into Spanish. Otherwise, I'm telling you, during holidays we were speaking Serbo-Croatian. It's just that, I'm telling you, parents sometimes used to mix the languages [...]"

Laura Papo Ostojić points out:

"Ladino culture is very important. I can't explain [...] I would so very much like to know [...] It would be beautiful to know. Only my mother spoke Ladino with her Jewish friends, but not with me. We spoke Serbo-Croatian. Our parents were mixing SerboCroatian and Ladino at home. I know very little Ladino. 'Linda, querida mia'. My mum always said it to me. There are some phrases like that still left, but it's a pity I can't speak or that I've never studied the language."

Across the three generations, the master narrative is a romantic longing for ordinary life in the Second Yugoslavia and the values such as security, stability and oneness. Simultaneously (and contravening) they are longing for Ladino. In fact, the Yugoslav period that the interlocutors remember nostalgically - first hand or through their parents - is a period that simultaneously suppressed their Sephardic linguistic background - since opportunities to maintain the language did not exist. The 72-year old, already mentioned Jakob Finci contemplates in this regard:

"My grandmother spoke Judeo-Spanish. It was the secret language of the elderly. Yugoslavia was a society without religious feelings. It was a pink socialism and the state provided you with free education, good health care and an apartment. Was it efficient? The majority of us still speak Serbo-Croatian today [...]"

On the one hand, it seems like my interviewees have internalized their need to adjust so much that they do not recognize what has happened. On the other hand, their expressed grief and the mere conversation about their linguistic biographies and regarding the dying Sephardic language may provide them with a greater degree of self-understanding and the ability to grasp that they were linguistically discriminated. 


\section{Conclusion}

Anderson's (2006) reflections upon the spread of nationalism are contradicted by the circumstance that nation-states are not necessarily homogenous in terms of cultural or ethnic affiliation (cf. Anderson 2006: 5-7; Hastings 1997: 3). The idea of mutually exclusive identities, i.e. that a person is either one thing or the other (a Serb, a Croat or a Jew) is a central aspect of a fundamentalist and extremist nationalistic narrative. This limited way of thinking creates the notion of us vs. them, and rejects multiple layers of identities (cf. Hobsbawn 1990: 174, 176). I argue that the intergenerational dialogue that I explore here can help to build a greater degree of self-understanding of how individual subjects negotiate multiple possible linguistic identities in order to build a sense of individual and collective belonging, which is a crucial prerequisite for constructive cultural diversity.

The language-shift from Judeo-Spanish to the national Serbo-Croatian was, just as in the cases of Arvanítika and Scottish Gaelic, based on the assumption that SerboCroatian is a power code (cf. Dorian 198; Tsitsipis 1998). For many Sephardim, Judeo-Spanish carried the stigma of an 'unsophisticated' language with which it was supposedly impossible to express modern ideas (Simović \& Filipović 2008: 309). In my case, the younger generations are more willing to call their language 'mixed' or 'Sarajevan' than the elderly - a pattern that is prevalent in the case of the many different Caribbean communities and their descendants in London as well (cf. Le Page/Tabouret-Keller 1985). Igor Kožemjakin stated:

"My [...] very difficult question, knowing the fact that there have been linguistic disputes. I don't know how to call it anymore [...] "mother language". So, I speak Bosnian/Croatian/ Serbian. I really don't know how to [...] Sarajevski [the "Sarajevo language"] would be the most appropriate name. Sarajevski."

The elderly insist on calling their language Serbo-Croatian, and the younger rely on destabilized and less-determined language forms, or a mix of several languages.

In the case of the Şehirli-Ottomans the Christian majority expected a national identity to be manifested by them/the minority (cf. Ellis 2003). In my case, the problem with the Sarajevo Sephardim's minority membership is that they are discriminated against by the Bosnian state. Jews are 'others' who do not declare affiliation with any particular group. In 2006, Jakob Finci tried to run for President by sending a letter to the central election commission. When asked whether he wanted to candidate as a Serbian, Croatian or Bosniak person, he answered 'as a Jew', and he was told that being Jewish was a 'private matter.' ${ }^{19}$

19 The information given by Jakob Finci on the 26th of December 2016. 
The discussion on linguistic identities and the sociolinguistic status of former Serbo-Croatian (i.e. how this linguistic category is to be classified) has become relevant since the rise of new state-structures in the 1990s (see Blum 2002: 129; Bugarski 2010: 44). The language situation in Bosnia and Herzegovina today consists of three inter-comprehensible languages. Bosnian-Croatian-Serbian (based on the very same neoštokavian [ekavian or ijekavian) dialects] has emerged as three different national standard languages because of state-regulated aims and elitist (academic) ideas. Clearly not every person, obviously not every Jew, in Bosnia and Herzegovina chooses to absorb these dictated linguistic identities in his/her own self-perception. Nonetheless, these chronologically different shifting concepts of South-Slavic nations-ethnicities-languages during the past two centuries have definitely affected South-Slavic linguistic identities and standard languages in numerous ways. For instance, the new political order of the 1990s led to a quite different process of language differentiation in which Bosnian-Croatian-Montenegrin-Serbian and other language-classifications and expressions emerged (cf. Blum 2002: 51; Voss 2008: 111).

In my case with the Sarajevo Sephardim, despite the shift in languages, the 'original languages' (i.e. Ladino and Serbo-Croatian) are dying but are not dead. This process is to a high degree related to the informants' self-identification in the new Bosnian context, i.e. through their thoughts regarding linguistic identification. Instead of referring exclusively to the formal language classifications, they say they still speak Serbo-Croatian, laugh, say "naš jezik" ('our language'), show grief in relation the new linguistic situation or even that they do not know what language they speak. The newly imposed standard languages clearly make the Sarajevo Jews linguistically divided.

I see the results from the nine Sarajevo Sephardim as preliminary findings, rather than as a truth-claim. Moreover, I consider my interviewees as forming a reference group rather than representing all possible responses to the question of linguistic identification. Although the interviewees represent just a small sample, I assume that they can provide the reader with a qualitatively rich idea of contemporary Jewish perceptions of linguistic identification in Sarajevo.

The second Yugoslavia period and today's situation in Sarajevo mark a particular point of departure in the Sephardic cultural experience in Sarajevo. The ambiguous mother tongue conceptions (as being reflected by the interviewees) are to my mind crucial components in the Sephardic contemporary culture of Sarajevo.

\section{References}

Anderson, Benedict (2006) (at first published 1983): Imagined Communities: Reflections on the Origin \& Spread of Nationalism . New York \& London. 
Astrologo-Fonzi, Laura (1992): Die Entwicklung des Judeo-Español - von der iberischen Heimat zum osmanischen Reich. In: Heimann-Jelinek, Felicitas/Schubert, Kurt (eds.): Spharadim Spaniolen. Die Juden in Spanien: die sephardische Diaspora. Wien. 127-134.

Benbassa, Esther/Rodrigue, Aron (2000): Sephardi Jewry. A History of the JudeoSpanish Community, 14th to 20th Centuries. Berkeley \& Los Angeles.

Birri-Tomovska, Kristina (2012): Jews of Yugoslavia 1918-1941. A History of Macedonian Sephards. Bern.

Blum, Daniel (2002): Sprache und Politik. Sprachpolitik und Sprachnationalismus in der Republik Indien und dem sozialistischen Jugoslawien (1945-1991). Heidelberg.

Bugarski, Ranko (2010): Multiple Language Identities in Southeastern Europe (with a Focus on Serbo-Croatian). In: Könönen, Maija/Nuorluoto, Juhani (eds.): Europe-Evropa. Cross-cultural Dialogues between the West, Russia, and Southeastern Europe. Uppsala. 34-49.

Dilthey, Wilhelm (1990): Über das Studium der Geschichte der Wissenschaften vom Mensch, der Gesellschaft und dem Staat. In: Die geistige Welt. Einleitung in die Philosophie des Lebens. Erste Hälfte: Abhandlungen zur Grundlegung der Geisteswissenschaften. Gesammelte Schriften. 5. 8. Göttingen.

Dorian, Nancy (1981): Language Death. The Life Cycle of a Scottish Gaelic Dialect. Philadelphia.

Ellis, Burcu (2003): Shadow Genealogies. Memory and Identity Among Urban Muslims in Macedonia. New York.

Gerson, Judith (2001): In Between States: National Identity Practices Among German Jewish Immigrants. In: Political Psychology 22,179-198.

Greble, Emily (2011): Sarajevo, 1941-1945. Muslims, Christians, and Jews in Hitler's Europe. Ithaca \& London.

Hastings, Adrian (1997): The Construction of Nationhood: Ethnicity, Religion, and Nationalism . Cambridge.

Hobsbawn, Eric (1990): Nations and Nationalism since 1780, Programme, Myth, Reality. Cambridge \& New York.

Hofmeisterová, Karin (2016): Juden. In: Králová, Katerina/Kocian, Jiri/Pikal, Kamil (eds.): Minderheiten im sozialistischen Jugoslawien. Brüderlichkeit und Eigenheit. Frankfurt am Main. 253-280.

Ivanković Mladenka (2009): Jevreji u Jugoslaviji (1944-1952). Kraj ili novi početak. Beograd.

Ivanković, Mladenka (2011): Jews and Yugoslavia 1918-1953. In: Bataković, Dušan (ed.): Minorities in the Balkans. Belgrade. 131-152. 
Jović, Dejan (2011): Reassessing Socialist Yugoslavia, 1945-90: The case of Croatia. In: Djokić, Dejan/Ker-Lindsay, James (eds.): New Perspectives on Yugoslavia. Key Issues and Controversies. London. 117-142.

Kerenji, Emil (2008): Jewish Citizens of Socialist Yugoslavia: Politics of Jewish Identity in a Socialist State, 1944-1974. (Dissertation at the Department for History at the University of Michigan).

Kerkkänen, Ari (2001): Yugoslav Jewry: Aspects of Post-World War II and PostYugoslav Developments. Helsinki.

Le Page, Robert/Tabouret-Keller, Andrée (1985): Acts of Identity. Creloe-based Approaches to Language and Identity. Cambridge.

Matasović, Ranko (1989): Romski Jezik. In: Lingvistički časopis 4:1. 116-119.

Ricoeur, Paul (1985): History as Narrative and Praxis. In: Philosophy Today 29:3. 199-218.

Shewmon Seitz, Elisabeth (2008): The Language(s) of Bosnian Jews Between Orality and Scriptuality. In: Berger, Tilman/Golubović, Biljana (eds.): Morphologie - Mündlichkeit - Medien. Hamburg. 263-276.

Simović Vučina, Ivana/Filipović, Jelena (2008): Language and Identity among the Sephardim in the Territory of the Former Yugoslavia. In: Sikimić, Biljana/Ašić, Tijana (eds.): The Romance Balkans. Belgrade. 303-318.

Stukenbrock, Anja (2005): Sprachnationalismus. Sprachreflexion als Medium kollektiver Identitätsstiftung in Deutschland (1617-1945). Berlin \& New York.

Sundhaussen, Holm (2014): Sarajevo. Die Geschichte einer Stadt. Wien.

Tsitsipis, Lukas (1998): A Linguistic anthropology of Praxis and Language Shift. Arvanitika (Albanian) and Greek in Contact. Oxford.

Voss, Christian (2008): Balkanische Spezifika des Nexus Sprache - Ethnizität als Methodenreflexion. In: Zeitschrift für Balkanologie 44:1, 109-121.

Wingstedt, Maria (1996): Language Ideology and Minority Language Policies: a History of Sweden's Educational Policies towards the Saami, Including a Comparison to the Tornedalians. Stockholm.

Zahavi, Dan (2003): Husserl's Phenomenology. Stanford. 



\title{
Aitor García Moreno and Dora Mancheva \\ Eating and Drinking among Bulgarian Sephardim at the Turn of the 20th Century ${ }^{1}$
}

\begin{abstract}
In this paper, we will focus on the edition and study of a small bunch of Sephardic primary sources - written in Judeo-Spanish -, and providing us with remarkable information about gastronomic life of the Bulgarian Sephardim in the beginning of the 20th century.

We will deal with advertisements published in the Sofia weekly newspaper El Eco judaïco in 1901, which deal with restaurants, cafeterias, and groceries. In addition, we will pay attention to those contents concerning food and beverages, found in pedagogical works containing specific glossaries and/or micro-dialogues, such as the Nueva metoda práctica de estudio de la lengua búlgara by Yáacob A. Gadol (Varna 1893, reed. Ruse 1894); Daniel Mefanov’s Малко словарче на френско-българско-еврейски език (Sofia 1896), and Albert Pipano's Diccionario judeo-español-búlgaro (Sofia 1913).

Throughout all these texts - belonging to what we could name as 'everyday life's literature' - we will approach Bulgarian Sephardim's daily life inside the Slavic milieu, in the concrete domain of dietary customs, so important in the Jewish cultural world.
\end{abstract}

Keywords: Sephardim, Bulgaria, 20th Century, Sephardic Press, Daily Life, Jewish Dietary Customs, Judeo-Spanish

\section{Introduction}

In his History of the Bulgarians of 1878, Konstantin Ireček offers some brief evidence about the Jews in the European part of the Ottoman Empire. He points out that Jews living there, mostly emigrants form the Iberian Peninsula, were mainly concentrated in the cities. They had their own villages in Tulcea, Ruschuk, Lom, Vidin, Pirot, Nis, Sofia, Samokov, Kyustendil, Plovdiv, Tatar Pazardžhik, Yambol, Thessaloniki and Bitola. In the Danuban wilayah there were 4,684 Jewish males $(2,374$ in the Sofia sanjak); in the Edirne wilayah there were 8,216 Jewish males $(1,415$ in the Plovdiv sanjak). According to Ireček, the Jewish population in the European part of the Ottoman Empire could be estimated at 95000 people (Ireček 1886: 722).

1 This article has been carried out within the framework of the Research Project, Sefarad, siglo XXI (2017-2020): Edición y estudio de textos sefardíes [ref. nr FFI2016-74864-P], funded by the Spanish Ministry of Economy, Industry and Competitiveness, MINECO. 
The Treaty of San Stefano, signed after the defeat of the Ottoman Empire in the Russo-Turkish War (1876-1878), restored the Greater Bulgaria, taking into consideration the history of political borders. On the territory of the Principality lived representatives of different ethnic and religious groups, including Jews. Most major Bulgarian cities after Independence had Jewish municipalities. According to a census conducted in 1878, 10,000 Jews lived in the Principality of Bulgaria, and in Eastern Rumelia they were 4,177. On July 9, 1880, the Bulgarian government issued the Temporary Legislative Provisions on the Governorship of Christians, Muslims, and Jews, which establish democratic rules for the election of the councils and the amount of the subsidy provided by the public treasury for each of the three confessions based on their representativeness in society.

In 1880 , there were already nearly 15,000 Jews in the Principality of Bulgaria, the increase to a large degree due to the resettlement of Jews from the other Territories under foreign rule. The legislation of the Principality was attractive because of the autonomous status given and the traditionally tolerant attitude of the Bulgarian community towards minorities. Representatives of the Jewish community were included in the newly established managing and representative bodies of the Third Bulgarian State. Sofia Chief Rabbi Gabriel Almosnino had contributed to saving Sofia from being burnt by the withdrawing Turkish army. Almosnino participated in the Constituent National Assembly held in Tărnovo in 1879 and put his signature at number twenty-four under the text of the newly adopted Bulgarian Constitution (Nedeleva 2013: 46-47).

The frustration of the unsuccessful national reunification because of the Treaty of Berlin (Bulgaria itself was excluded from participation in the talks at Russian insistence) was so massive that in 1885, after a bloodless insurrection in Eastern Rumelia, the Principality of Bulgaria annexed the province, gave back the selfesteem of its population as subjects of an independent country, capable of acting out against the will of Russia and taking the reins of its own destiny. According to the first censuses, twenty-one nationalities coexisted in the Bulgarian territory in 1888. The most important minorities were the Turkish, the Romanian, the Gypsy and the Jewish. The Jews were about 23,500 , which corresponded to $0.75 \%$ of the population. Almost all were Sephardophones. They resided mainly in the big cities like Sofia, Plovdiv, Ruse, Vidin, Yambol, Lom, Varna, Kazanlak, Kiustendil, Samokov, etc. The 'Jewish' city par excellence was Dupnitsa, whose population was almost $25 \%$ Sephardic. In the first census carried out in 1881 according to the modern methodology, 14,020 people were self-proclaimed as Spanish Jews, which together with the 4,177 'uncertain' (the respective column indicates 'Jews' and not 'Sephardic Jews') of Eastern Rumelia, amount to a total of 18,197. Their 
number grew to 38,553 in 1910 and during the Balkan wars it decreased slightly (mainly because of the lower number of marriages and the lower birth rate).

The Jews from Plovdiv Perciado Cohen and Eliezer Kalev, the Arie family from Samokov, among others, were the first ones to build their houses according to the modern concept: the home is a symmetrical residential building, introducing the opportunity for a new type of living, prestigious display not only of the degree of social achievement and domestic culture, but a real, new type of urban form of social life, approaching the Balkan settlements to the European city. The Jewish elite became the pioneers and Maecenas who, with their homes, gave visibility to the dwelling, moving it out of the courtyard, showing its beauty and distinction, corresponding to the place of its residents in the historical development and the economic and cultural life of society. This type of buildings soon become recurrent in Pazardžik, Stara Zagora, Sliven, Kazanlak, Karlovo, Koprivshtitza, Panaguyurishte, Yambol, etc. The furniture and all the home decoration came with caravans from Paris, Vienna, London, Triest, and so on (Roshkovska \& Lozanova 1998: 36-37). The wealthy Jews, both women and men, brought the $\dot{a}$ la franca apparel and imported the first landaus and chariots drawn by English and Andalusian horses with expensive harnesses and a coachman (Roshkovska \& Lozanova 1998: 24-28). The Jewish upper-class, however, were not limited to only showing opulence: they sponsored the literary and school affairs of their home towns, helped education flourish, and maintained the self-consciousness of the unified Bulgarian nation for whose future as an enlightened and cultured European people they had all struggled together (Roshkovska \& Lozanova 1998: 47).

The opening of the Alliance Israélite Universelle's first school in 1870 and the subsequent real boom of seven new schools within only a decade (with two coeducational and one only for girls [Mancheva 2014: 456]) marked a milestone in the Western influence and helped strengthen contacts with the Ashkenazi community as well. An increasing number of Bulgarian Sephardim changed their traditional study destinations abroad from Thessaloniki and Constantinople to Vienna and other Ashkenazi cultural centers (Schmid \& Bürki 2000: 17). The Jewish Folk Choir, created in Sofia in the early 20th century, an event in the cultural life of the capital city, was preceded by a number of singing groups composed mainly of students, among which the most important was Levyim. These circumstances, together with the rise of immigrants of Jewish descent from Russia, Poland, and other Central European countries to Bulgaria, marked the spectacular growth of the non-Sephardic Bulgarian Jews from 301 people in 1888 to 1565 in 1910 (Mézan 1925: 87). Given the cyclical occurrence of anti-Semitic waves in Europe, the case of Bulgaria was almost idyllic (Raichevski 2008: 47). In 
the years before the Independence, there was evidence of violence against Jews in different parts of the Ottoman Empire and the neighboring countries. The reason for this were mostly prejudice and superstition, somewhat reinforced by the Greek clergy. Claims were repeated that the Jews used Christian blood for their religious rites. There is a refutation of this information in the Bulgarian press. ${ }^{2}$ The official newspaper of the central Consistory, El Eco judáïco, records that in 1901 the relations between the community and the Bulgarian government had a clear norm in which the Chief Rabbi enjoyed absolute authority as a community leader and counterpart of all the ministers, who could at any time, upon his discretion, call the Head of the government and obtain an audience almost immediately.

Religion, language, and gastronomy are some of one people's cultural pillars, and all three elements are exposed to change across time, by means of contact with other cultures. In this paper, we will focus on the edition and study of a small bunch of Sephardic primary sources written in Judeo-Spanish and providing us with remarkable information about gastronomic life of Bulgarian Sephardim, in the turn of the 20th Century. Throughout these texts, belonging to what we could name as 'everyday life's literature', we will approach Bulgarian Sephardim's daily life inside the Slavic milieu, on the concrete domain of dietary customs, so important in the Jewish cultural world.

\section{Description of Primary Sources}

Our corpus comes from texts created at the turn of the 20th century, published in Sofia and Varna, and - to a certain extent - representing different diatopic varieties of the Judeo-Spanish from Bulgaria. The sources exemplify the diaphasic variation as well, since the data originate from documents representing several registers.

Among these sources, there are two dictionaries, which are rather simple listings of words: ${ }^{3}$

1) Alḅert Pipano’s bilingual Diccionario judeo-español-búlgaro (Sofia 1913), and

2) Daniel Mefanov's trilingual Малко словарче на френско-българско-еврейски език (Sofia 1896).

2 (Nedeleva 2013: 43) with a reference to the Levant Times (newspaper of July 6th 1874).

3 For the presentation of examples, we follow the transcription system devised by Hassán (1978) with those little changes proposed by García Moreno (2004: 31-33) specially relating the use of $<\mathrm{r}>$ and $<\mathrm{rr}>$ according to modern Spanish normative orthography. 
We also make use of:

3) A conversation guide entitled Nueva metoda práctica de estudio de la lengua búlgara (Ruschuk 1893) written by Yáacob A. Gadol, and

4) A set of seventeen advertisements mainly published in the Sofia weekly newspaper El Eco judáïco in 1901, dealing with restaurants, cafeterias, and groceries. ${ }^{4}$

The Diccionario judeo-español-búlgaro contains though a sort of conversation handbook, where there are five chapters related to food and beverages. Those micro-dialogues, together with the phrases in the Nueva metoda práctica, destined to improve the translation skills of the pupils, provide for some sociolinguistic data too, as the words appear within the context of specific situations.

\subsection{The Diccionario judeo-español-búlgaro ${ }^{5}$}

Albert Pipano's Diccionario judeo-español-búlgaro [hereafter $D J B$ ] was printed in 1913 in Sofia by Nades̀da publishing house. Its author was the son and grandson of Chief Rabbis; a highly educated businessperson, a man of the world and an active philanthropist.

The $D J B$ shows a certain lack of domain-specific knowledge in lexicography, but Pipano's fluency in many languages, broad culture, and common sense compensate for this limitation. The $D J B$ contains a list of 3.608 Sephardic lemmas in rashi characters, their translation into Bulgarian (in Cyrillic letters) and a sort of a phonetic transcription of the Bulgarian words, written in Hebrew script. In addition, there is a conversation guide, which contains useful phrases and expressions, grouped into 32 themes. There are as well 19 announcements, giving publicity to the professional activities of 16 Sephardim and three Bulgarians.

The lexical inventory related to eating and drinking contains about a hundred words. There are nouns (names of fruits and vegetables, different sorts of meat, beverages, tableware, etc.), verbs (related to those bare necessities), and adjectives and adverbs describing flavors and sensations of gustative experiences.

\subsection{The Малко словарче на френско-българско-еврейски език ${ }^{6}$}

The so-called Малко словарче на френско-бтлгарско-еврейски език [The Little Lexicon of French-Bulgarian-Hebrew (Jewish?) Language] [hereafter $L L$ ] by

4 Two of those ads did not appear in El Eco judáïco but they belong to Pipano's dictionary.

5 See also (Collin \& Studemund-Halévy 2007: 16; nr. 23).

6 See also (Collin \& Studemund-Halévy 2007: 93; nr. 158). 
Daniel Mefanov has as a subtitle (also in Bulgarian) "3,000 words most used in everyday life."

The author, born in Yambol and a graduate of the school of the Universal Israelite Alliance in Paris, was a long serving French teacher in southern Bulgaria. The $L L$ appeared in 1896 at the publishing house Nades̀da of Sofia (Mancheva 2002 and 2008a). There are two copies of the source in Bulgaria: one in the National Library of Sofia, and a second in the National Library of Plovdiv. Plovdiv's library copy is much better preserved. On its back cover, the full name of the author and his position (French teacher of the Jewish school in Sofia) are printed (Mancheva 2014: 458). Seven more works by the same author - posterior to the $L L$ and created with the purpose of teaching French to the general Bulgarian public - can be found in Plovdiv's library.

The cover pages, the editorial colophon, and the subtitles of these 'new' books have added data that allow tracing the vital and professional path of Mefanov. His first position as a French teacher was at the Israeli School of Sofia (1896). He later continued teaching French in Sofia until at least 1906. By 1910, he was probably practicing in the Danubian city of Lom, eventually taking up a post at the Kazanlak State School of Pedagogy (1912) and ending his admirable teaching career at the no less prestigious Boys' Lycée of Kyustendil (1914). There is one curious fact about Mefanov: he signed his first book, the $L L$, with the Jewish name of Daniel (or Danaíl), but subsequently adopted that of Dimitar, of Greek origin, one of the most common male names in the Bulgarian onomastics. ${ }^{7}$

The $L L$ consists of 80 pages (ca. $11 \times 14 \mathrm{~cm}$.) numbered the Christian way, from left to right. It is structured in three columns: the one on the left includes the French words (in Latin characters), the central one, the translation into Bulgarian (in Cyrillic), and the one on the right the translation - in spite of what the title says - into Judeo-Spanish, also in Cyrillic script. In all probability, the work intended to teach French to Sephardic (or Bulgarian) mother tongue pupils. Most likely Mefanov had extracted the words listed in his vocabulary from the Israeli School of Sofia's textbook, with the goal of smoothing the way for his students. The usual rush in the beginning of the 1896-1897 school year is the likely reason for the inaccuracies - quite rare in Nades̀da's editorial work - that the $L L$ shows in many aspects: alphabetical ordering is irregular, entries repeat, there is an endless number of typographical errors, etc. To make things even worse, there are four blurred sheets (Mancheva 2014: 457-458).

7 The abbreviated form "D. Mefanov" is the most frequent on the covers of his books (Mancheva 2014: 459). 
Given the circumstances, it is necessary to exercise caution with the entries related to the culinary habits of the Sephardic people of Bulgaria: in fact, we confine ourselves to analyze only the 'unambiguous' words, either approved by the Jewish dietary laws, or corroborated by other sources as possible food.

\subsection{The Nueva metoda práctica de estudio de la lengua búlgara ${ }^{8}$}

Yảacob Aron Gadol wrote his manual entitled Nueva metoda práctica de estudio de la lengua búlgara [hereafter NM] to help the Sephardim study the Bulgarian language. The volume appeared in 1893 in Rustchuk (although the foreword was apparently composed in Varna), in Yosef Pérez̀ Alcalay's publishing house. The book became an instant success, which led to a second edition the following year (Mancheva 2008a). ${ }^{9}$ The Chief Rabbi made a brief review in a digest specialized in science, literature, and social life news, where he proclaimed it the official textbook for the Sephardic kids in Judaic schools to learn 'their mother tongue' and recommended it as a remedial vademecum to all Sephardic families (G[rünwald] 1894: 135). It is one of the relatively rare didactic works using Judeo-Spanish as a language of instruction.

We do not know much about the author, although a recent historical study of the city of Ruse as an intellectual capital of Bulgaria between 1864 and 1948 demonstrates that he was a professional pedagogue (Zheinov 2014: 275), and apparently a teacher of French. Besides some Gallicisms, which substitute outdated Turkish loan words in the Nueva metoda, French synonyms (between brackets) are often used for the explanation of grammatical categories or terms. We can only deduce that his origins are also from Ruse, as the surname Gadol has uniquely been documented in this Bulgarian city (Faigenboim et alii 2003: 267, s.p.v.).

The NM is written the Christian way, from left to right. Its 127 pages are distributed as follows: after the Preface (5-6) there is an Introduction (7-10) containing a table of Bulgarian letters (printed in cursive) and their aljamiado homologues (in Rashi and in square script). On page 11, there are two texts in Bulgarian for reading and writing exercises with marked accents, on page 12 there are 17 proverbs in cursive script. From page 13 to page 109 there are 107 teaching units, and pages $110-120$ are dedicated to a review for which short texts on a wide

8 See also (Collin \& Studemund-Halévy 2007: 96; nr. 163).

9 The unique copy of the first edition belongs to the Jewish Theological Seminary of New York, which we have had the chance to use thanks to the kindness of our exceptional colleague Dov Cohen. 
variety of subjects in the Bulgarian language are selected aiming to enrich the student's vocabulary. On pages 121-123 there are specimens for official correspondence (with both Bulgarian and Ladino versions), mainly related to the financial sphere. A two-page appendix, called Lexicon, explains fifty elements of the grammatical terminology: the brief definition is followed by the homologue of the term in Bulgarian and sometimes in Ladino. On page 126, misprints are listed, and page 127 includes a bilingual terminology glossary. Also, on the same page 126, the author expresses his gratitude to those who have encouraged him to create this tool for learning the Bulgarian language.

There is no doubt that the NM is the work of a teacher: The organization of the syllabus requires specialized skills and knowledge. The material is presented starting from the easiest to the more complex elements and in certain aspects, it is better compiled in comparison to some foreign language textbooks used in Bulgaria at a much later stage. Didactic units usually have three elements: a glossary of twenty to forty words in Bulgarian with a pointed accent, a translation from Bulgarian to Ladino to exercise the same vocabulary, and a translation from Ladino to Bulgarian working towards reaffirming the grammar rules and the vocabulary from the previous lesson.

The dictionary is well balanced between a few conjugated verbs (gradually increasing difficulty in different times and modes), nouns (both common and proper), adjectives (with their possible pairs of antonyms) and several particles, conjunctions and prepositions.

There is a special chapter dedicated to the article, the formation of the plural of names (themes 27-29), the numerals (themes 31 and 58), the different classes of pronouns (themes 43, 50 and 56), etc. Sections 24, 40, 71 and 95 are revision chapters.

The NM is a delightful and - largely - modern manual, conceived by a person with a solid education and an obvious talent to teach. However, some of its features may differ from the typical data brought by the contemporary sources from Bulgaria and the Balkans: its Judeo-Spanish is 'modernized' with standard Spanish forms, instead of using the genuine Sephardic ones. The influence of French on Gadol's textbook is not only linguistic: France, a country which in the eyes of people living in the Balkans symbolizes the new civilization model, appears as the standard-bearer of modern stateliness and the only European nation capable to change the course of history (Vesselinov 2003: 5). The ethical and moral values of the Declaration of the Rights of the Man and the Citizen somehow underlie the distribution and the contents of teaching units. The obvious ambition is to educate the students in the spirit of the highest moral principles such as respect for all nations, religions, and professions. The strong 
conviction that justice, tolerance, integrity, and courtesy are an essential part of the code of conduct of a worthy human being is conveyed to the young people for whom the textbook is intended. There is as well a profound love for Bulgaria and its beautiful nature and a certain pride in being a citizen of the world.

The author's great objectives explain why the proportion of gastronomy-related vocabulary is so limited and there is no special chapter dedicated to it. It is not surprising though, that in the first extremely brief three chapters the words pan ('bread') and sal ('salt') are taught, probably referring to the ancient Slavic tradition - adopted as well in Lithuania and Romania - to welcome guests with bread and salt.

\subsection{The Weekly Newspaper El Eco Ĵudáïco}

The weekly newspaper El Eco Ĵdáico: Organ del judaísmo búlgaro (Gaon 1965: 20, nr 24) [hereafter $E \hat{J}]$ made its first publication in Sofia under the direction of Albert Pipano, on February 15, 1901, and came out regularly until 1907 (Israel 1967: 167).

Each number consists of eight pages with three columns each, and numbering continues from one number to another. It is organized in major sections (Partida oficiala, Partida no oficiala, De la semana, Jurnales y literatura) with each section containing also a header (De las comunidades, De la civdad, De la provincia, De el mundo judáïco, etc.). Most issues include a serialized novel, usually translated from Hebrew or French. On the last page, there are often short commercials in which Jewish establishments and joint ventures promote their activities. There are only a few doctors or teachers' announcements; generally, advertisers were either small businesspersons (owners of bars and cafes, hoteliers, tailors, merchants, etc.) or relatively large companies (Banco Šequel, Primera fábrica búlgara de calzado Progreso, Sociedad La Hermandad, etc.).

For our sample, we have selected fifteen commercials of bars, cafeterias, hotels, and grocers published in 1901 different issues.

\section{Study}

In the next pages, we will present and comment the gastronomic information contained in all the aforementioned sources, arranging it within the following semantic fields: 1) food; 2) beverages; 3) selling prices, and 4) culinary habits.

\subsection{Food}

In this section, dedicated to foodstuff (artícolos de comaña [Tk. kumanya] or comeres as we read in $E \hat{J}$ advertisements, comida in $L L$, or provisiones ['victuals'] 
in $D J B$ ) we will treat separately $a$ ) vegetables, $b$ ) meat, $c$ ) fish, and $d$ ) other ingredients of the Sephardic diet.

\subsubsection{Vegetables}

Chapter 74 of $N M$ cites fifteen names of fruits, whose hyperonym for fruit could be both the feminine fruta, and the masculine fruto. The most interesting of these terms are: higo ('fig'), manżana ('apple', called manzana in DJB and malzana in $L L$ ), membrillo ('quince', together with the most genuine bembrilllo ${ }^{10}$ ), naranja - glossed with the most common Turkish word portocal ('orange', also found in $L L$ and $E \hat{J}$, while in $D J B$ appears as portucal) -, nuez ('wallnut', mueź in $D J B$ ), and pruna ('prune', also present in the $L L$, and called pruma in $D J B$ ). The most intriguing forms are the gloss źerdeli for albaricoque ('apricot') - which is exclusive to Kurdish -, as well as the unique form šeftelí (Tk. şeftali), a gloss for albérchigo ('clingstone peach', lit. 'Persian [apple]'), so the assimilated form is only known in Lezgin language of Dagestan and Azerbaijan.

In the $L L$, the list of vegetables - called źarźavat ( $<$ Tk. zerzevat) -, legumes and fruits increases. In it we can find: alveana ('hazelnut'), amoras ('blackberries'), anĝenares (< Gk. aүkıvápa, cf. Tk. enginar 'artichoke'), bamia(s) - also appearing in $D J B$ ('okra') -, briśco (< [malum] persicum, cf. Rus. nepcuk 'peach'), fustuques (<Tk. sing. fistık 'peanut'), grahes (Bg. grakh 'peas') - together with garbanzo (Sp. 'chickpeas', JSp. 'peas'), also present in EJ ad nr 12 (infra) and the loan bilibiśes (<Tk. sing. leblebi 'chickpea') -, carpuź(< Tk. karpuz'watermelon'), habas pretas ('black beans'), lentejas ('lentils'), lichuga ('lettuce'), merenĝena

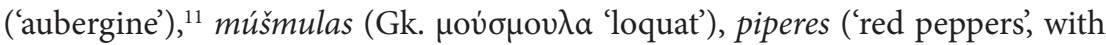
a common loanword to many Slavic languages, $c f$. for instance Tk. biber), urtigas ('nettle'), and zafañiorias ('carrots'). Among them, some spices as g'injambre ('ginger'), hardalo yabani (cf. Tk. yabani hardal 'wild mustard'), perjil ('parsley'), and safrón (Tk. safran 'saffron') appear. In addition, in ÊJ ad nr 12 (infra), we find as well vanilla (cf. It. vaniglia 'vanilla').

As for $D J B$, it adds aḅricoques ('apricots'), biźelia ('pea', and the syn. perśila, of Romance origin [Mancheva 2004: 43]), carpuz ('watermelon'), cómpir (< Dial.

10 Roden (1996: 310b) explains that in the Bulgarian version (called Pollo con bimbrillo) of the common Sephardic recipe for Poulet aux coings, "the chicken and quince fried separately, than cooked together with salt and pepper and liquid caramel."

11 Roden (1996: 258) points out that the Rodanchas de berengena is a "speciality of Salonika." 
- Gm. Grumbier 'potato'), limón ('lemon', also present in Ể), pera ('pear'), uva ('grape'), and višna ('sour cherry [Prunus cerasus]').

The proof of the excellence of Yaacob Gadol as a teacher and of his linguistic awareness is the inclusion of the three Bulgarian same-family lemmas meaning respectively 'eat', 'food' and 'cereal' translated into Judeo-Spanish with como, comida and źairé (< Tk. zahire), glossed trigos. The only edible grains mentioned in NM are trigo ('wheat', present in DJB too) and cebada ('barley'), because of their use to make bread, while $L L$ also offers mijo ('millet'). Other cereals like arroź ('rice') and mumurús ('maize', < Slav., with a regressive assimilation [cf. Mladenov 1941: 261, s.v. кукурузъ, and Miklosich 1886: 146, s.v. kukuruzŭ]) can be found in $D J B$, together with the generics farina (It. and West Ibero-Romance) and harina ('flour'). Lastly, the necessary yeast to make bread (pan fresco blanco/ de cebada) that becomes bayat ('stale, not fresh') after some time appears in $L L$ as levadura.

As seen, Turkish and Bulgarian loans are numerous; therefore, the high percentage of vocabulary of Ibero-Romance origin (or having Spanish as an intermediary language) found in the $D J B$. Is worth noting thus, in the field of vegetables, we could point to canela (DCECH h. $1250<$ It. cannella), fabas 'beans' (as in Gal. and WestAst.), or patata (DCECH, s. XVIII).

\subsubsection{Meat}

Compared to vegetables, references to meat or meat products are very few in our sources, but the structure of the corpus does not differ significantly. It seems that the proportion of nonstandard words in $L L$ is more important: codrero ('lamb') - facing the standard cordero, that we find in $N M-$; goevo (güevo in $N M$ and $D J B$, 'egg'), goeso ('bone'), godrura ('tallow, lard'), poerca ('sow'), and sarsicha ('sausage'). In $L L$ there are very few words taken from French, like pijón ('pigeon', glossed by guš < Tk. küşs 'bird') for DJB's palomba (Ast., Gal., It.). On the contrary, the Turkish language is apparently quite manifest as - to our knowledge - this is the only source form Bulgaria where Turkish words appear in syntagms like poerco yaḅaní (lit. 'wild pig', 'wild boar' [cf. Mancheva 2004: 45]).

The Ibero-Romance component predominant in $D J B$ offers us, among others, leche ('milk'), manteca ('butter', as in Old Portuguese, Modern Galician and Asturian, $c f . D C E C H$ s.p.v.), and vitela (Pt.) of animal origin. However, there are Turkish loans too like mandra ( $<$ Tk. mandira 'small dairy'), together with words which have had Bulgarian and/or other Balkan-Slavic languages as an intermediary (Mancheva 2008b) like biḅa ('turkey'), cašcaval (Tk. kaşkaval < It.), etc. 
Comparatively, ÊJ advert offer a higher amount of meat products and plates - most of them named by loanwords - like asado (Sp., also present in $L L$ ), braśola breśola (It. bresaola), carnazas, quebapes (cf. Tk. sing. kebap), and salami (It.), as we can read in the following ads: ${ }^{12}$

\section{[1] CAFENÉ COMERCIAL}

Tengo el honor de enformar el honorado público que en mi local se topan diferentes bebiendas a precios convenibles. Una bira regal, 10 zt.; de miśmo tengo salami, quebapes, breśolas y diversas otras źakuskas: lo tođo kašer.

ŠEMU'EL B. BAHÁN ${ }^{13}$

\section{[2] CAFENÉ STANCIA TRANVAY}

Tengo el honor de enformar el honorađo púḅlico que abrí en Kñiajevo un café, y por Pésah terné tođo mođo de bebienda pascual; se topan también asađos, carnazas, braśolas, etc., lo tođo pascual.

YEHUDÁ ŠELOMÓ ${ }^{14}$

\subsubsection{Fish}

Relating to fish, $D J B$ offers the Ibero-Romance synonyms peje and pešcado (the latter included in $N M$ too) for the hyperonym, together with the mention of the concrete kind palamida (Gk. $\pi \alpha \lambda \alpha \mu i \delta a$ 'bonito fish') by using a loanword.

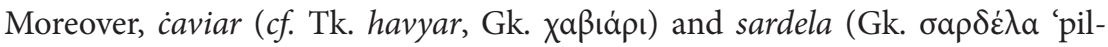
chard'), two more concrete samples named by a word of foreign origin, can be found in $D J B$ and $L L$, respectively.

\subsubsection{Others}

Among other ingredients of Sephardic cuisine like aćeite 'oil' (Êj, appearing as feminine la esta aceite in $N M)$, azúcar 'sugar' $(D J B)$, or sal 'salt' $(E \hat{J})$ - and excluding the beverages we will present in the next section -, we must mention $L L$ 's plates named by terms taken from Turkish/Balkan languages. From Bulgarian, we find popara ('a meal made with leftover bread, butter, feta cheese, and boiled water or milk', cf. Balkan Slavic, Gr., Tk., apud Mladenov 1941: 482,

12 Considering the series of words where the term źakuskas (Bg. sing. закуска 'breakfast, brekker', but 'snack' in general too) appears in $E \hat{J}$ nr 1, we can understand it is referring there to some sausages and other cold meats. Vid. ref. 37 infra.

13 E) I:1 (02/15/1901), p. 8c.

14 ÊJ I: $6(03 / 21 / 1901)$, p. 48 a. 
s.p.v.), and yáreḅiŝa ('partridge', cf. Mladenov 1941: 703); and from Turkish we find chorba ('vegetable soup') in front of general supa of French origin (soupe). Precisely, supa is the form present in $D J B$, as there are relatively less words of Balkan origin in it, apart from baclava ('id'), mastica ('aniseed-flavoured aperitif') or šurup ('syrup'). ${ }^{15}$

Last, in this same source, among other sweets (dulzuras in ad nr 14 [infra]), we find biscotos ( $c f$. It. sing. biscotto 'biscuit'), while the form galeta, of French origin (galette $>$ Sp. galleta 'biscuit'), corresponds to Bg. галета ('breadcrumbs'). In turn, ice cream is referred both by dondurmá (Tk. dondurma) and by $\hat{g} e l a t a$ (cf. It. gelato).

\subsection{Beverages}

One of the phrases contained in NM says Bebe vino, agua, bira, té (chay), café $y$ otras agradables bebiendas. ('Drink wine, water, beer, tea, coffee, and other pleasant beverages') and includes most of the beverages (called beberajes in DJB and bebraje in $E \hat{J})$ cited in the sources handed for this study.

$L L$ brings also petmeź ('a drink of boiled dessert wine with pieces of pumpkin', cf. Вg. петмез 'molasses') and, in general, presents an appreciably higher percentage of Turkish and Bulgarian and less French or Greek loanwords than the vast majority of the contemporary sources form Bulgaria. A significant number of lemmas correspond to pluralia tantum and the author often resorts to a descriptive definition of the French entry in Judeo-Spanish instead of a translation in the strict sense: rakí de arroz ('arrack'), rakí de cereźas ('kirsch'), chay con vino ('sangria'), etc.

$D J B$ includes the inherited words leche 'milk' and zumo 'juice', as well as Turkish loans like boźá (Tk. boza 'beverage made of slightly fermented millet'), while bira (< It. birra 'beer') is only mentioned once, in the chapter En el café [At the Café]. To all appearances, this was the best place to enjoy not only beer but also a cup (filyán [Tk. filcan] in LL) of Turkish coffee (café turco) or caffé latte (café con leche), some tea (chay [Tk. çay]), or a glass (vaśo) of absinthe (absent) or vermouth (vermut).

A caḅareto ('pub, bar'), a taberna ('tavern'), or a meané (Tk. meyhane 'barlike restaurant') - all cited in $D J B$ - were also good places to have a drink (and eat something too). ${ }^{16}$ Moreover, as we can read in the following advertisements

15 Although the three terms come from Turkish (baklava, mastika and şürüp, respectively), they are common to many local languages.

16 In ad nr 8 (infra) we also find the word restorán (Fr. restaurant 'id'). 
on two birarías (It. sing. birreria 'beer hall') - the second one also called cafané (Tk. kahvehane 'cafeteria') -, this kind of commercial establishments used to be located in the busiest areas of the city; for instance, in front of the tramway station at Dondukov Blvd., close to the Shoemaking Company, in Sofia: ${ }^{17}$

\section{[3] BIRARIA «GAMBRINUS»}

Tengo el honor de enformar el honorado púḅlico que la stación del tramvay para Kñájevo (Ỵalí Efendi) será enfrente la biraria "Gambrinus» ande J́an, a_lado del Obustarsko Drújestvo, Dondukov Bulevard, ande se topa siempre de la renomada bira de la fábrica de Ruschuk Ḥaberman. Bira fresca en VAśo REgAL, 15 ZT. En miśmo tiempo se topan diferentes źacuscas, quebapicos frescos -3 por 10 zt.- kašer. Todo modo de bebienda a 10 zantimos.

Estó convencido que los honorados clientes se toparán contentes de todas las bebiendas, de la presteźa y limpio servicio.

El que gusta beber una buena y sabrośa bira, que venga a_la biraria «Gambrinus» ande J́an.

Siendo el repośo del tramvay dura media hora, ansí que la honorada púḅlica tiene el tiempo de escansar y beber una bira con quebapes.

J́AN B. VARSANO ${ }^{18}$

[4] AVIśo

Tenemos el honor de haćer saber al honorađo público que venimos de abrir una cafané y biraría con el nombre Bacius en bulevar Dondúkov, enfrente la stación del tramvay para Kñàjevo. En esta biraría se topan buenos asađos kašer, tođo mođo de bebraje espirituośo, bira de Bratia Prošékovi a 15 zt. la copa grande. Tođo es serviiđo presto, limpio y convenible.

SIMÓN MÁRCOV Y COMP. ${ }^{19}$

Or near a well-known building like the hotel Breznik, appearing in three advertisements of our sample:

[5] RUSCA PARNA CHAINA

Tengo el honor de enformar mis honorados clïentes que transportí mi cafené en úlisa Niška ${ }^{20}$ a_lado del hotel Bréźnik.

Café, 5 zantimes.

ŠEMU'EL B. COHÉN ${ }^{21}$

17 See also ads nr 1 (supra) and nrs 10 and 14 (infra).

18 Ể I:1 (02/15/1901), p. 8b.

19 Êे I:20 (07/05/1901), p. 163a.

20 Former Niška St. (nowadays called Blvd. Todor Alexandrov) is a central street of Sofia near the Synagogue, which used to be plenty of small shops, artisan's studios, and family hotels. See an epoch's picture at http://stara-sofia.com/nishka.jpg.

21 Ể I:9 (04/19/1901), p. 72a. 
[6] RUSCA PARNA CHAINA

Tengo el honor de enformar mis honorados clientes que transportí mi cafené en úlisa Niška a_lado del hotel Bréźnik.

ŠEMU'EL B. COHÉN ${ }^{22}$

[7] AVIśo

Tengo el honor de enformar a tođos los señores viajadores por Sofia que vengo de retirarme del hotel Bratia Ivanov que yo tenía hasta hoy y arquilí el hotel BRÉZNIK, úlisa Niska, en compañía del Si. Bejor Š. Caracáš, dubnisalí.

El hotel, que es nuevamente fraguado, tiene limpias camaretas, buen acomodamiento, güerta, locanda y buenos bebrajes.

DAVID BENÓN Y BEJOR CARACÁŠ ${ }^{33}$

As it still happens nowadays, restaurants and bars used to be the appropriate places for the celebration of important events like balls, weddings, and other meetings, as we read in:

[8] NUEVO NUEVO

Do a_saber al honorađo púḅlico que abrí en la úlisa Ẑar Kaloyán, nú. 12 y en la úlisa Clementina, nú. 141 un restorán kašer con diferentes beberajes. Aḅonados se reciben con precios convenibles, presto y limpio serviimiento. Tengo a dispośición salón para bal, bodas y conferencias de sociedades.

Con respecto

DAVID DIAMANT ${ }^{24}$

Apart from bars and restaurants, and still according to $D J B$, there were specialized liquor stores where the owner (called viñatero) kept bottles or carafes (redomas) of all sorts of wines and spirits: vino Málaga, vino Madera, vino Evxinograd, ${ }^{25}$ vino corolado francés, together with cherry, plum and grape liquors (višnovca, raquí de pruma, raquí de dǵibra).

In the text, there are some other curious entries like alcol ('alcohol; liquor') or alambic ('alembic'), which probably do not come from the indigenous alcohol or alambique, but are rather recent Gallicisms.

$22 E \hat{J} \mathrm{I}: 8(04 / 12 / 1901)$, p. 64 b.

23 ÊJ I:5 (03/15/1901), p. 40c.

$24 E \hat{J} \mathrm{I}: 23$ (08/02/1901), p. 187c.

25 This is one of the most famous Bulgarian wines from the Royal winery at the Black Sea coast. 
Finally, also related to drinking, some of the genuine Sephardic forms included in $D J B$ - and often existing in non-standard general Spanish, too -, are: borrachez ('drunkenness') or gomitar ('throw up'); together with some loanwords like sequeośo sequïośo ( $<$ Pt. sequioso 'thirsty'), ${ }^{26}$ and many newly coined words as borrachear ('booze, get drunk habitually'), agrïado ('gone off'), agüento ('watery'), etc.

\subsection{Selling Prices}

Apart from the mention of food and beverages, commercials stand out for including reference to the prices, the measure units, and the currencies handed at the time.

Together with a good location, affordable prices (precios convenibles) or offers (including a discount or rebato [Gm. Rabatt]) are commonly part of the commercial strategy to attract customers (el honorado público or los honorađos clientes) both in restaurants like:

\section{[9] CAFENÉ YERÚŠALEM}

Tengo el honor de haćer saber al honorađo púḅlico que en mi cafené Yerušalem, situađo en pasaj Svetí Nicola, se topan diferentes guiśađos, asađos, con muncha limpieźa y precios convenibles. Se topa también chay y cavé.

\section{ŠELOMÓ YA'ACOB ELIYÁ QUIUSO ${ }^{27}$}

and in grocers' or magasenes (Fr. magasin), as we can see in:

[10] AVIŚo

En muestro magaśén yentro el beźistén [Tk. 'covered market'], se vende: cavé prima y diversas caliđađes a precio de fr. 2,20 y endelantre el quilo; arroź Paźarŷik prima cualitá, 45 zantimes el quilo; azúquer quismé, 70 zantimes.

PINHAS Y ARIÉ 28

[11] AVIśo

En nuestro magaśén, situađo en el beźistén, se venden cavés de tođas las cualidađes, empezando del precio de 2 levos y endelantre; el que toma un quilo se haće $5 \%$ de rebato. Se topan también aćeites de buenas cualitás a diversos precios muy convenibles.

PINHAS Y ARIÉ 29

26 In $N M$ there is a difference in the auxiliary verb of estar hambriento ('to be hungry') and tener sed ('to be thirsty') - while the most elegant way to refer to the last concept is estar alterado (de sed) ('to be upset, to be annoyed').

27 Ể I:31 (10/04/1901), p. 228 b.

28 Ể I:3 (03/01/1901), p. 24a.

$29 E \hat{J} \mathrm{I}: 29(09 / 13 / 1901)$, p. 212 c. 
As seen, the mention to the quality (JSp. calidad, cualidad or cualitá) of the products (ropas) never lacks. Usually, this reference to the quality means differences in the price, as we read also in the detailed list of products sold in the stocked grocery store of the following text:

[12] AVIśo

\section{ECONOMÍA PARA LAS FAMÍAS}

Tenemos el honor de enformar al honorađo púḅlico que en el magaśén que venimos de abrir en bulevar Dondúkov, nú. 16, enfrente el tramvay de Kñàjevo en la fragua de Si. Yiş̧̧ac Šelomó Táŷer, vendemos tođa sorta de artícolos coloniales, drogas y ahtarlic y diferentes otros artícolos de comaña, ropa de prima cualitá a precios muy convenibles:

\begin{tabular}{|c|c|}
\hline café natural prima cualitá & $" 2,50 "$ \\
\hline café segunda" & $" 2,30 "$ \\
\hline café moliđo menuđo sin mlezcar & $" 3,50 "$ \\
\hline dito segunda cualitá & $" 3$ " \\
\hline dito trecera" & $" 2,60 "$ \\
\hline arroz Paźarŷik prima cualitá & $" 0,45 "$ \\
\hline rbanzo gođro & $" 0,30 "$ \\
\hline menuda & $" 0,20 "$ \\
\hline
\end{tabular}

Dulce blanco (deva) de Costantinópoli laborado con portocal, limón, vanilla con güesmos hermośos, a 0,90 el quilo. Molinos de café, peines fildiší prima cualitá, máquinas por bullir café y otros artícolos de Turquía.

J̌abón turco fino extra a 0,90 zantimes el quilo; de este jabón es bastante de tomar un quilo en lugar de una oca.

Con una vis̀ita a nuestro magaśén, nuestros honorađos clientes se convencerán que vendemos ropas buenas a precios convenibles.

Estos precios son por el detalio; en grupo haćemos rebato.

DANÓN Y ABDALÁ ${ }^{30}$

As seen, the most common measure unit for selling detailed products is the quilo ('kilogram') but the oca (Tk. okka 'oke; a Turkish and Egyptian weight measure equal to about $23 / 4$ pounds, that is, 1,282 grams) is mentioned too.

On the other hand, prices are nominated in francs $(f r .=$ francos $)$, cents $(z t$. $\sim$ zantimes $\sim$ zantimos) or levs (levos [cf. Bg. sing. лев] in ad nr 11]). Its importance can be appreciated in the following NM's sentence (p. 80): ¿Cuánto vale esta aceite y esta harina? ('How much is this oil and flour?).

30 E) I:12 (05/10/1901), p. 100a-b. 


\subsection{Culinary Habits}

Before entering this last paragraph devoted to culinary and dietary habits among Bulgarian Sephardim at the turn of the Twentieth century, we must mention general terms still non-cited like NM's double entry for 'cooking' (guiśar, aparejar) or DJB's synonyms cuećer and coćinar for 'cook', and polysemic entries as asar ('bake; roast'), and comida ('plate; course').

In the conversation guide of $D J B$, there are eight chapters related to the culinary habits of the Bulgarian Sephardim. Despite the labels desayuno and dejenar (Fr. dejeunner 'breakfast'), deśayunar ('have breakfast'), medio-día ('lunch') and comer de noche ('dinner') - which LL brings as vecherear ('dine', on Bg. вечеря/vecherya 'dinner') -, all of them presuppose a dialogue between a client and a waiter (called mozo, garzón [< Fr. garçon], or kélner $[<$ Bg. $<$ Gm. Kellner $]$ ), or a grocer (called bakal [Tk. bakkal]).

According to the text (p. 86), the usual meal hours apparently were as follows: Mañana a las siete deśayunamos, a las 12 comemos por medio-día y la noche (la tarde) a las 8 y media cenamos ('we have breakfast at seven o'clock, at twelve we have lunch and at night (evening) at half past eight we have supper').

Judging by the same guide, the usual breakfast or brekker (called źacuscas in $E \hat{J}$ ads nrs 1 and 3 ) was composed of fried eggs and sausages ([unos cuantos] güevos fritos and sarchichas), a cup of milk, a little bit of white bread with a little bit of butter (un poco de pan blanco, un poco de manteca), cheese and fruits. At lunch, one could order fried chicken (pollo sofrito) ${ }^{31}$, fish, or meat, and have with it a glass of wine or an entire carafe (vaśo or redoma). It seems the dinner was quite copious: a soup, a salad (salata), beef stew (carne de vaca bullida con źarźavat), veal or lamb - steak or chop - with spinach or cabbage as a side dish (vitela asada/cordero asado/con spinaca, con lagná, costías de cordero/costías de vitela) served with white or red wine. The general word for dessert is fruta or meźé ('meze') ${ }^{32}$.

In NM, the sentence Traed_me una porción, dos platos, un tenedor (pirón [<

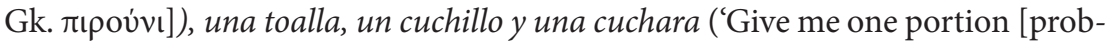
ably for 'small plate'], two plates, a fork, a napkin, a knife and a tablespoon'), likely represents the habitual table setting, and the order of disposing the crockery, the cutlery and the napkin from left to right. It is notable that, among the tableware

31 Vid. Roden (1996: 309) for the recipe.

32 Albanian, Bosnian, Bulgarian, Macedonian, Serbo-Croat. Greek and Romanian < Tk.; syn. of zakuski, vid. Kaneva-Johnston (1992: 59). 
or takum de meśa, the percentage of terms from Bulgarian found in $L L$ is unusually high, like for instance cháynik 'teapot'.

In $D J B$, dishes and orders describe a refined gastronom (Fr. gastronome 'gourmet') taste: queśo de Ŝvî́era (Graviera) ('Gruyere cheese'), pedazo de filé ('tenderloin') together with a short list of exquisite wines for every occasion. This is comparable to what we saw in ads 3 and 4 (supra) with the promotion of concrete beer brands (Haberman and Bratia Prošecovi, respectively) or we can see in $\mathrm{nr} 13$, by bringing our attention on a famous cigarette-paper trademark: ${ }^{33}$

[13] AVIśo

En la botica de Si. Šelomó Šabetay Táŷer, sarraf Bulevard Dondúkov enfrente la stación del tramvay para Kñajevo, se topan a vender papeles de cigarras para guilźas con marca «Gregoriadis y Mišáikov». Un topićico de 1000 papeles costa 0,20 zantimes. ${ }^{34}$

In addition, it is quite significant that there is a special entry la más mejor cualitá ('the very best quality'), which reflects its importance for Pipano and his readers (Mancheva 2010), as we have already pointed out for Ej commercials. ${ }^{35}$ Also in $N M$ (p. 42), there are a few mentions of the sybaritic lifestyle of the urban elite in Bulgaria:

- Dámed-me de la mejor comida que tenéš aquí ('Give me the best food you have here').

- ¿Cuála es la mejor bebienda? ('Which is the best beverage?')

- ¿Cuála es la mejor calidad del vino? ('Which wine has the best quality?')

- ¿De ónde mercáš estas buenas bebiendas y comidas? ( $¡$ Where do you buy those good beverages and foods from?)"

With regard to Jewish dietary rules (kashrus), it is interesting to note that in $L L$ there are several terms that largely transgress Leviticus 11 and Deuteronomy 14 regulations, like pruidas ('mussels'), carne de haźir ('pork'), and godrura ('lard'). This is somewhat surprising, considering the recurring allusion to cleanness (limpieźa) - especially in Passover (Pésah) - and kosher products (por el kesherut $y$ por pascual) found in announcements like:

33 See Romero \& García Moreno (2013: 129-131) on more popular cigarette-paper brands.

34 ÊJ I:12 (05/10/1901), p. 100b.

35 Two more adverts included in $D J B$ tend to confirm a similar image; thus, the delicatessen shops of Yisḥ̣ac D. Arié and Refael A. Arié were selling fine foods (delicatezas) and beverages: vinos de provenencia franceśa, italiana y hispanía, vinos vermut de Torino, coñaques y liquiores franceśes, amer picón, čhampañas de diferentes marcas, etc., etc. 
[14] AVIŚO IMPORTANTE. A LOS SI.RES VÏAJ́ADORES A SOFIA. RESTORANT CAŠER EVROPA

Tengo el honor de informar al honorado púḅlico judió que en caleja Pasaj Svetí Nicola número 9 se topa mi restorant cašer bien resentado con buena limpieźa y presura de servir guiśos diferentes y asados, como y diferentes dulzuras el día y la noche. También recibo angajamentos de fiestas diferentes a precios convenibles. Rogariya todo el viajador a Sofia vis̀itar mi local y non bušcará más otro semejante.

Con respecto, MoÍs LEVí ${ }^{36}$

\section{[15] AVIśo}

Tengo el honor de haćer saber al honorađo público que en mi magueśén [sic] Abram Menif, situađo entre la úlisa Pírotska, úlisa Stradja, se topan aćeites de susam para Pésah prima cualitá al precio de 1,80 el quilo, véndida el ingroso. Por el kešerut y por pascual, ella es eśaminađa del Bet-din haŝédec de nuestra civdađ según atestađo en mi pođer número 52 .

NISIM ABRAHAM DAVID ${ }^{37}$

\section{[16] CAFENÉ COMERCIAL}

Tengo el honor de enformar al honorađo púḅlico que por la fiesta de Pésah mi café es entero pascual, ande toparán también y diversos comeres y bebiendas.

ŠEMU'EL B. COHÉN ${ }^{38}$

There is no other mention or reference to kashrus either in the $D J B$ or in the conversation guide, while in $L L$ there are two entries referring to trefá ('unclean') food: godrura y godrura de puerco, and two more expressions contrast with the relative austerity and moderation of the gastronomic lexicon collected in it: vivir boeno ('reveller') and flaco vino ('plonk').

Lastly, the lesson in both etymology and healthy habits is contained in NM's teaching unit nr 35 (p. 14). There, surprisingly, vinagre ('vinegar') is listed immediately after el vino ('wine') and in its micro-dialogue section, we find the phrases: Más sana cośa que la agua no hay ('There is nothing healthier than water'), and ¿Cuál pan es más provechośo, el fresco o el seco? (Which bread is worthier: the fresh one or the dry one?'), in the same line that Por mí la mejor bebienda es la agua buena, ma y el vino no es negro, cuando bebes poco. ('In my opinion, the best beverage is the good water, but wine is not bad either, if you drink it moderately').

$36 D J B$, p. 14.

37 Êे I:4 (03/08/1901), p. 32 b.

38 Eरि I:6 (03/21/1901), p. 48a. 


\section{Conclusions}

One could suggest that at the beginning of the 20th century the dietary habits of the Bulgarian Sephardic community were fairly flexible, and the rabbis were directed much more by common sense than by religious fervor. Suffice it to take the example of the celebrations of Pésah in nisán of 6661 (March-April 1901). The fellow believers from Samokov did not have a new sieve and the elders allowed the re-utilization of the one from the previous year, on condition of cleaning it well with a brush under the supervision of the haham and not using the flour of the first sifting for the ritual bread:

"Según deciśión del Bet-din-hagadol, se respondió telegráficamente (nú. 257): «Siendo tiempo corto, permetemos solo soto surveenza del hajam. Alimpiado con furcha. Primera harina non emplead por Pésah»." (Eco 5: 34-35)

The community of Sofia had been deprived of kosher sugar, a situation that had been exploited by some unscrupulous people, importing sugar without a certificate or seal of kashrut. To settle the matter, the court made the decision to proclaim the sugar in large plates, produced by the factory of Sofia, as apt for the sacred use.

"A la fin, en baśa de la controla hecha del Bet-din-hasédec en la fábrica de azúcar en Sofia, visto la mancanza de tiempo, el Bet-din-hasédec permete a servir por Pésah solo de la azúcar hecha en la misma fábrica en plochas grandes, la cuala puede toparse en cuala fuese botica." (Eco 5: 35)

On the one hand, according to the socio-cultural data extracted from the sources, we can conclude that the Sephardic community in Bulgaria at the turn of the century was pretty secular, modern, and westernized, and Sephardim belonged to the country's urban elites at the time.

On the other hand, as demonstrated, the vast vocabulary explored in these pages related to the kaleidoscopic world of food and beverages, shows us the impact of - mainly - three different cultural influences on the Bulgarian Sephardim and the Judeo-Spanish they spoke: the Ibero-Romance tradition; the Slavic milieu and the French/Western modernity.

\section{References}

Benbassa, Esther/Rodrigue, Aron (2002): Histoire des Juifs sépharades: de Tolède à Salonique. Paris: Le Seuil.

Collin, Gaëlle/Studemund-Halévy, Michael (2007): Entre dos mundos. Barcelona: Tirocinio. 
DCECH = Corominas, Joan/Pascual, José Antonio (2012): Diccionario Crítico Etimológico Castellano e Hispánico [CD]. Madrid: Gredos.

Faigenboim, Gilhereme/Valadares, Pablo/Campagnano, Ana Rosa (2003): Dicionário sefaradi de sobrenomes. Rio de Janeiro.

Gaon, Moshe David (1965): A Bibliography of the Judeo-Spanish (Ladino) Press. Jerusalem. [In Hebrew].

G[rünwald], M[oritz] (1894): Български прегледъ [Bulgarian Review] 2, 135.

Ireček, Konstantin (1886): История на българите [History of the Bulgarians]. Tărnovo: K. Tuleshkov Printing House.

Israel, Salvator (1967): Периодичният еврейски печат на ладино и иврит в България [Jewish Journals in Ladino and Hebrew Published in Bulgaria]. In: Годишник на обществената културно-просветна организация на евреите в Народна република България 2: 139-168 [Annuary of the Public Cultural and Educational Organization of the Jews in the People's Republic of Bulgaria].

Kaneva-Johnson, Maria $\left(1999^{2}\right)$ : The melting pot. Balkan Food and Cookery. Trowbridge, Wiltshire: Cromwell Press.

Mancheva, Dora (2002): Tres trabajos lexicográficos sefardíes de Bulgaria. In: Alberto Bernabé \& alii (eds.): Presente y futuro de la Lingüística en España. Madrid, 428-434.

Mancheva, Dora (2004): De rebus nature: la flora y la fauna en dos diccionarios sefardíes de Bulgaria. In: Proceedings of the Twelfth British Conference on Judeo-Spanish Studies. Leiden, 39-47.

Mancheva, Dora (2008a): Един век сефарадска българистика [One Century of Sephardic Studies on the Bulgarian Language]. In: 45 Años de Licenciatura en Filología española en la Universidad de Sofía San Clemente de Ojrid. Sofia, 127-135.

Mancheva, Dora (2008b): Los rastros del búlgaro en la parte judeoespañola de un diccionario trilingüe francés-búlgaro-sefardí. In: Cuadernos del Instituto Historia de la Lengua 1, 75-86.

Mancheva, Dora (2010): Разговорникбт на Алберт Пипано: още едно доказателство за ползата от изучаване на мъртвите езици [The Albert Pipano's Conversation Guide: Yet Another Evidence of the Benefit of Studying Dead Languages]. In: MVSARVM SEMPER AMATOR, Studia in memoriam Prof. D. Boyadzhiev. Sofia, 112-120.

Mancheva, Dora (2014): Cultivar nuestro jardín: una obra pionera de la lexicografía sefardí en Bulgaria. In: María Luisa Calero \& alii (eds.): Métodos y resultados actuales en Historiografía de la Lingüística. Münster, 454-464. 
Mancheva, Dora (2019): Glosas Sofiensas: edición crítica aumentada del Diccionario judeoespañol-búlgaro de Alḅert Pipano. Sofia.

Mézan, Saül (1925): Les juifs espagnols en Bulgarie. Sofia: Amishpat.

Miklosich, Franz (1884-1890): Die türkischen Elemente in den südost- und osteuropäischen Sprachen... In: Denkschriften der Kaiserlichen Akademie der Wissenschaften, Philosophisch-Historisch Classe. Wien, Bd. 34, 1884: 239-338; bd. 35, 1885: 105-192; bd. 37, 1889:1-88; bd. 38, 1890:1-194.

Miklosich, Franz (1886): Etymologisches Wörterbuch der slavischen Sprachen. Wien.

Mladenov, Stefan (1941): Етимологически и правописен речник на българския книжовен език [Etymological and Orthographical Dictionary of the Standard Bulgarian Language]. Sofia.

Nedeleva, Petya (2013): Място и роля на еврейската общност в български те земи (от Османско владичество до 30-те години на XX век) [Place and Role of the Jewish Community in Bulgarian Land (from the Ottoman Empire until 1930)]. In: Law Journal of NBU, 2013/2, <http://old.nbu.bg/PUBLIC/ IMAGES/File/departamenti/pravo/lawjournal2013/august/5_Law\%20 Journal_2_2013_petya_nedeleva.pdf> [last access on 25-04-2018].

Raichevski, Stoyan (2008): Българи и евреи през вековете [Bulgarian and Jews: a common history]. Sofia: Bulgarian bestseller.

Roden, Claudia (1996): The Book of Jewish Food. London: Penguin Books.

Romero, Elena \& Aitor García Moreno (2013): Del narguilé a los cigarrillos: un ejemplo de la modernización del mundo sefardí de los Balcanes. In: MarieChristine Varol \& Rosa Sánchez (eds.): La presse judéo-espagnole, support et vecteur de la modernité. Istanbul, 113-142.

Roshkovska, Anna/Lozanova. Sasha (1998): Eвреите и българската градска култура [The Jews and the Bulgarian urban culture]. Sofia: Graphica 19.

Schmid, Béatrice/Bürki, Yvette (2000): "El haćino ima'ginado": comedia de Moliére en versión judeoespañola. Edición del texto aljamiado, estudiado y glosario. Basel: Romanisches Seminar der Universität Basel.

Vesselinov, Dimitar (2003): История на обучението по френски език в България през Възраждането (xviii-xix) [History of the French Language Teaching in Bulgaria During the National Renaissance (xviii-xix)]. Sofia.

Zheinov, Ivo (2014): Русе, столица на книгопечатането (1864-1948) [Ruse, the Capital of Book Printing (1864-1948)]. Ruse. 



\title{
Agnieszka August-Zarębska and Tomasz Zarębski \\ Language as Oikos: The Case of Margalit Matitiahu's Poetry
}

\begin{abstract}
The aim of this paper is to study the poetic works by Margalit Matitiahu, written in Judeo-Spanish, by reference to the interdisciplinary reflection on home as proposed by Tadeusz Sławek, Aleksandra Kunce and Zbigniew Kadłubek (2013) and defined by them as oikology. Such a reading of Matitiahu's poems reveals multi-layered nature of her oikos - i.e. home or place of belonging in physical, cultural and symbolic meaning - which combines her present Israeli cultural identity with the history and cultural legacy of her Sephardic ancestors. The central aspect to be analyzed is the Judeo-Spanish language, chosen by her as a means of expression in times when it is regarded as severely endangered.
\end{abstract}

Keywords: oikos, oikology, Judeo-Spanish, Sephardic poetry, Margalit Matitiahu

In the recent years, Tadeusz Sławek, Aleksandra Kunce and Zbigniew Kadłubek (2013) initiated a reflection on the meaning of the term 'home' and its various manifestations in the language and cultural texts, describing this analysis as oiko$\log y$, "the study or science of houses/homes". ${ }^{1}$ This proposal, multi-faceted and interdisciplinary, seems still open, as its heuristic potential surpasses definitely the boundaries of cultural anthropology, ethnology or politics concentrated on preserving local historical memory, permeating into the area of literature studies and philosophical reflection on the subjectivity. The aim of this article is to continue and amplify the reflection on oikology by using it as an interpretative frame for literary texts; to be exact, a number of selected poems by an Israeli author Margalit Matitiahu.

What is oikology and what perspectives does it open for literary interpretation? Etymologically, the subject of its studies is oikos, an ancient Greek term meaning 'house,' 'dwelling', 'residence,' 'family', 'fatherland', as well as its derivatives: oikeios - 'homely', 'familiar', 'congenial,' 'intimate,' 'belonging to', or oikeion (also oikeios) - 'family member' (but also 'slave', 'servant'), 'relative', 'kin', 'an intimate friend' (Węclewski 1929: 476-477). Although the founders of oikology,

1 For the sake of clarification, it is appropriate to specify that what Sławek, Kunce and Kadłubek set out is rather philosophical and speculative considerations that go far beyond the ordinary and down-to-earth sense in which oikology concerns mainly the maintenance, sanitary conditions of houses and homes. 
being more interested in the present, do not concentrate their research on the ancient world, in order to establish basic meanings of the words deriving from the root oikos, they turn to ancient literature. Thus Kadłubek, presenting the bases of oikology (Kadłubek 2013: 168-169), mentions, by way of introduction one of the platonic dialogues, Lysis (dedicated to friendship), in which Socrates is reported to conclude during his conversation with the aforementioned disciple (Lysis) that friendship is condensed in the noun oikeion. Developing this line of thought, Kadłubek makes use of the interpretation of Lysis performed by Gadamer (1980), who stresses that oikeion is a colloquial term for a place "where one feels at home, where one belongs and where everything is familiar" (Gadamer 1980: 18), a place that pertains to him/her and she/he pertains to it, it is something "that answers to me and that to which I answer, because it pertains to me"2 (Gadamer 1980: 19). According to Gadamer (and Kadłubek) in Lysis the term in question expresses a tense relation, in which longing and fulfillment coexist, and embraces "a need of that which pertains to me. And that is a need which does not cease when it is met, and that in which the need finds fulfillment does not cease to be dear to me. That which pertains to me and to which I belong, is as reliable and constant for me as everything in my household" (ibidem). It seems that among many connotations and interpretative hues that can be traced with reference to the analyzed Greek term the one that stands out is the concept of belonging to.

Moreover, Plato's Lysis and its Gadamerian interpretation suggest implicite a continuous dialectics of longing and fulfillment - the mutual relationship between the two does not end when the longing is satisfied, it does not become something durable, closed, finished. As a result, oikos is not something to which we simply pertain, but a goal to be continuously achieved, a place to be re-discovered. Therefore Kadłubek, additionally employing philological data, reminds us that the Indo-European root of oikos, VIK, includes in its semantic field the concepts of being in the course of "settling down, getting inside, coming home, entering a certain state" (Kadłubek 2013: 169-170), from which he deduces that home is "a nonplace of eternal coming" (ibidem).

The reference to Augé and his concept of non-places (fr. non-lieux) supports the view that oikos does not need to be something fixed, immovable, but quite the contrary: it may be inscribed in constant change, which is either forced upon it (by historical, family or economic circumstances), or voluntary. We navigate through the vicissitudes of our lifetime we try to tame, 'domesticate' the

2 In German: "auf das man hört oder das auf einen hört". 
encountered reality and we keep asking questions about our place of belonging. This situation is especially common nowadays, which finds its reflection in the field of humanistic and social studies, where the issue of ever-changing reality and (the lack of) belonging has grown into one of major topics of analysis. ${ }^{3}$

In any case, according to Kadłubek the semantic filed of oikos comprises the notions of both transitiveness and arrival: "In essence, from the etymological point of view, oikology may manifest itself in phrases or terms in which transiting, going, coming, approaching are the basic areas of meaning, becoming a kind of hodosophy" (Kadłubek 2013: 170). ${ }^{4}$ Home is a place where you arrive, but also leave (voluntarily or not), change, move - which involves the idea of transitiveness - and then again arrive at something, someplace that becomes a new home, and so on. In this context the question about belonging - about where and what to we belong, and what belongs to us - begins to exceed the simple understanding of home as a house, as a certain section of space or a physical spot; we may find our oikos in a real house in which we used to live, with its characteristic atmosphere, habits, attitude towards the neighbors, its surroundings (a village, a district), but it may also be found in language, literature, religious customs, sometimes superstitions, evoked in proverbs, typical sayings or specific names of things. This list could be continued. Approaching oikos from this perspective we are entering the area of hermeneutics.

Sławek, Kunce and Kadłubek occasionally refer to the founders of hermeneutics, mainly Heidegger (although it seems that Ricoeur with his proposal of "narrative identity" may also be an enriching source of inspiration for oikology $y^{5}$, and obviously this link is not accidental. The term oikos, although not as basic and fundamental as Heideggerian Dasein, 'being-there', 'being-in-the-world' etc., is nevertheless closely connected with this concept. How we discover our belonging, what our home is, what we identify with, what the building blocks of our 'I', of our identity, are - all those may be considered manifestations of our being (Dasein). Thus oikology may be perceived as intellectual reflection on one of the aspects of Dasein - namely the one that constitutes our belonging to oikos.

Following this train of thought, one could say - partially with reference to Ricouer - that looking for one's home, one's place, and ultimately one's 'I', one's

3 Zygmunt Bauman's concept of 'liquid modernity' (2000) may serve as a good example, another one being the aforementioned theory of 'non-places' by Marc Augé (1995).

4 Hodosophy may be explained as 'wisdom of the road', 'wisdom consolidated along the way' (gr. hodos - 'road', way and sofia - 'wisdom').

5 See Ricoeur 1992 and an investigation into the relationship between Ricoeur's hermeneutics and literature in Reut 2010: 61-75. 
'identity' requires narrative, telling a story, expressing oneself. Sometimes this narration takes on the form of literature, although not necessarily prose, which might be suggested by the term 'narrative', but also poetry or drama. Indeed, there is a kind of writing in which different facets of oikology are explored (Sławek et al. analyze numerous examples from this area), and such literature reflects the authors' search for their oikos. Therefore, the oikological approach may turn out to be useful when applied to literary studies.

The literary production of an Israeli author Margalit Matitiahu is a good example of writing where such a perspective may be employed. It should be admitted that the unobvious meaning of oikos is rather typical of the Jewish culture circle, as its members tend to live in diasporas, on the intersection of different languages and cultures, at the same time showing concern for continuity and upholding the community and family past. However, Matitiahu's poetry stands out as a particularly clear case of 'home-seeking. The first argument to support this claim is that the poet chooses as a means of her poetic expression the Judeo-Spanish language, also known as Ladino or Judezmo, ${ }^{6}$ which was the language used by her parents and herself in her childhood (however, she used other languages in different contexts). It should be kept in mind that this language is considered to be endangered (Harris 1994; Harris 2001). The second important argument in favor of the abovementioned claim lies simply in the content of Matitiahu's poems, where we witness a hermeneutic dialogue with her family's and community's past, and this dialogue causes a shift towards new layers and new aspects of 'being-in-the-world'. Such search for oikos may be compared to deciphering a palimpsest - under the outer layer of writing other meanings and directions are to be discovered.

In order to better understand the approach adopted in this article, it seems necessary to mention a couple of biographical, as well as bibliographical facts regarding Matitiahu. She was born in 1935 in the Land of Israel (as Jews used to refer to their country before it was officially established in 1948), into a Sephardi family of Greek roots. Her parents grew up in a Sephardi community in Thessaloniki, but, being young and convinced that the Land of Israel should be their home, they left Greece, thereby leaving behind most relatives. Most probably that decision saved their lives, as $95 \%$ of Jews from Thessaloniki, 43000 ,

6 In this article all the three terms describing this language will be used as synonymous, leaving aside the terminological differences outlined by specialists in Sephardi linguistics. Matitiahu herself seems to prefer the terms 'Judeo-Spanish' and 'Ladino' (see: Matitiahu 2001b). 
were deported to concentration camps between March and August 1943, and the vast majority were gassed shortly after arrival (Fleming 2008: 125).

It should be highlighted that the Greek city was not merely one of many Sephardi communities in the Turkish-Balkan diaspora, but, along with Istanbul, the most significant one. Refugees from Spain started to settle down in the area as early as the end of 15th century, shortly after their expulsion from Spain, and they were welcomed by the Ottoman authorities' intent on colonizing the newly conquered region of the empire. In the following decades and centuries the local community grew considerably. Due to its harbor, within a short period, Thessaloniki developed into a major Mediterranean trade center controlled predominantly by Sephardi Jews, as well as a place of dynamic growth of crafts, textile production and, unquestionably, culture and religion, as the affluent families brought voluminous libraries which, supported by local patrons, gave rise to an important center of Torah studies. A couple of printing offices were set up whose initial focus on the Hebrew works expanded into a larger scope of JudeoSpanish religious literature starting from the 18th century. Afterwards, in the 18 th and 19th century press and lay literature appeared in Thessaloniki, especially Sephardi versions of the European novels and theatre plays characteristic of those times. ${ }^{7}$

For a long period of time the Sephardim were the most numerous ethnic and religious group in the multicultural Ottoman city, and the Judeo-Spanish language reigned on streets and in the harbor. Sometimes Christians and Muslims were also able to communicate in this language on a basic level. As Jews were members of all social classes and representatives of almost all professions, in the reminiscences of the city dwellers and their descendants, as well as in the broader group imagination inspired by the Sephardi sources, Thessaloniki is considered a legendary Sephardi paradise, a real Sephardi metropolis. Some historical accounts refer to it by the title 'mother city of Israel' or 'Balkan Jerusalem' (Molho 2013: 290). During the Balkan wars the leaders of the local community tried to persuade the European empires and Jewish world organizations to support the idea of converting Thessaloniki into a free city, exempt from the supervision of any state (Fleming 2008: 68-70).

In 1913 , when the city was annexed to Greece, Jews made about $40 \%$ of the population ${ }^{8}$. The new authorities introduced a policy of Hellenization; still, until

7 On the history of Thessaloniki see e.g. Benbassa, Rodrigue 2004 and Molho 2013; on the literature, Díaz-Mas 1986: 131-184 and Romero 1992.

8 Orthodox Greeks made $30 \%$, Muslims $25 \%$ and other ethnic groups the remaining $5 \%$ (Fleming 2008: 86). 
1923 the community enjoyed many liberties, as having a right to days off on Sabbath and other Jewish feasts (ibidem: 87). However, the community experienced a considerable blow in 1917, when a huge fire consumed large sections of Jewish districts situated in the city center whose partially wooden houses were crammed close together. Also, many synagogues, libraries, schools and archives were lost to fire, which fact was assiduously taken advantage of by the new authorities willing to replace the multicultural character of the metropolis with a modern Greek identity informed by the Hellenic tradition.

In the 1920s and 1930s a gradual exodus of the Sephardim takes place. They often choose to re-settle in the countries of the so called Second Diaspora, while the Greek population grows. Probably Matitiahu's parents belonged to that emigration wave propelled by the surging nationalism and antisemitism. However, the picture of the city they kept at heart was one of the Sephardi, Judeo-Spanish cultural cradle. The following events of Holocaust, which ultimately terminated the Sephardi chapter of Thessaloniki, contributed to this idealization and even mythologization. Naturally, the events of World War II left a sense of devastating loss, augmented by the perceived indifference of the Greek toward the Jewish plight and their eagerness to seize hold of the abandoned houses and institutions, accompanied by a repression of the memory of Sephardi presence in that area (see Pfeffer 2013).

Describing her childhood, Matitiahu highlights the fact that the language of her family household was Ladino, but her education was carried out in Hebrew, as result of the efforts by the authorities to unify the citizens of a freshly established state of Israel ${ }^{9}$. She published her first poetry volumes in the 1970s, They contained poems written in Hebrew, being, of course, directed at the Hebrew reader.

The year 1986 brings a clear change of direction - Matitiahu's mother dies and a few months later the author sets out on a journey to Greece, where she looks for traces of her family's and their community's past. It is important to mention that the first two books which may be considered the fruit of that tour, Kurtijo kemado [Burnt Courtyard] (Matitiahu 1988) and Alegrika (Matitiahu 1992), were published in a bilingual, Judeo-Spanish and Hebrew, version. From this it may be gathered that the poems included in those volumes were directed at the Hebrew-speaking reader possessing a certain degree of fluency in Ladino. Obviously, the poems may be as well read by Hebrew-speaking readers who are

9 Matitiahu stresses a strong influence of her mother, an advocate of 'tolerant Zionism', on shaping her personality, worldview and political beliefs. Her sense of belonging to the Hebrew nation is founded, in the first place, on the political principles of justice, co-existence and equality, religion being a secondary factor (see Morales 2005: 11). 
not familiar with the Sephardi language, but simply identify with their ancestors' culture. In the publications and re-editions that follow important changes are introduced on the linguistic level. First, they are published in Spain ${ }^{10}$ in JudeoSpanish only; second, the spelling applied resembles the norms employed in Spanish. It may be assumed that the purpose of these innovations was to make Matitiahu's poetry accessible to the Spanish-speaking reader. Indeed, compared to other Sephardi authors, Matitiahu seems to enjoy great popularity in Spain, as may be concluded from invitations to numerous festivals, as well as from the fact that in 1997 a fragment of her poem was engraved onto a monument commemorating an ethnic cleansing incident perpetrated in 1196 by the armies of Alfonso VIII of Castile and Pedro II of Aragon against the Jewish community of Puente Castro district in León. ${ }^{11}$ Due to this inscription, the monument acquired the status of a symbol of reconciliation between the descendants of Spanish Jews and Sefarad, their homeland during many centuries from which they were expelled.

Based on Matitiahu's biography and literary path, it can be supposed that the shift towards Ladino is an oikological decision, as the author seems to find in it a safe haven where she can express things with an authenticity that Hebrew or other languages she speaks do not provide. Let us highlight that Judeo-Spanish is not her language of everyday communication and in that sense it cannot be treated as her first language. However, it was spoken by Matitiahu's parents, and she chooses it as a language of her personal expression, a means through which she wants others to understand her, elevating it to the rank of her unique individual oikos. On the other hand though, it is also her cultural oikos, shared by other Sephardi Jews, a common space of sounds, a speech shared by the community in Thessaloniki to which her forebears belonged.

How is the choice of language reflected in Matitiahu's poetry? The death of her mother is a clear turning point, as the author is given a dramatic impulse to reflect on her family's lot, which is hinted upon already in the first poem opening the book Kurtijo kemado. The author's journey towards her origins, being at the same time a journey towards Judezmo, begins symbolically at her mother's grave.

\footnotetext{
"Before leaving for the door of your childhood

I came my mother

To knock on the stone of your eternal home
}

10 In 1997 Matitiahu publishes two books of poetry exclusively in Ladino: one in Israel, Matriz de luz (Matitiahu 1997), another one in Spain, Vela de la luz (Matitiahu 1997a). The second volume comprises some pieces published earlier in Kurtijo kemado and Alegrika.

11 See Red de juderías de España - Caminos de Sefarad. León. 
And to tell you that I go

Where your soul grew up

Where your father sowed in you the seed of poetry." (Matitiahu 1988: 9) $)^{12}$

The poem describes the author's visit to the cemetery ${ }^{13}$, referred to as the 'eternal home' (kaza eternel), which is a calque of a Hebrew phrase bet ha-olam (literally 'the house of eternity'). This is a place where the author's desire to talk to her mother rebounds off the cold barrier of the earth and stone. Also, the plan of going to visit Thessaloniki, her mother's birthplace, is conceived there (or at least is formulated); the poet refers to it with the phrase portal de tu chikes (ibidem), 'the door of your childhood. The door, or, to be exact, the doorpost, the threshold of the house, as this is portal's true meaning in Ladino, makes reference to the origins of life and the cultural roots of Matitiahu's mother. On the other hand, analyzing this image in the context of the author's life, we may interpret it as a threshold she has to pass in order to touch the truth about her own history and identity. She feels a necessity to physically get inside houses that were once filled with Ladino sounds and culture in order to be able to find them inside herself, and preserve them.

In Jewish houses the doorpost is a place to affix mezuzah. Jews touch it in order to be reminded themselves about the essence of Judaism. We can observe an analogy between this ritual gesture and Mattiahu's desire to touch the difficult truth about the Greek past of her own cultural community and keep that truth inside herself. She refers to this ritual directly in a different poem, where she writes: "with a mark of pain in the body/ like a mezuzah/ kiss it, kiss it and remember" (Matitiahu 1988: 13).

The intensity of emotions expressed in the poem Antes de arrivar a Saloniki [Before the Arrival to Thessaloniki] contrasts with the silence of the cemetery and the heftiness of the tombstone. Still, in the end, the author decides to break the silence with her whisper, she wants to be heard:

\footnotetext{
"I'm coming closer to your silent pain

To stones which have no light

But all this was not in vain

I'm gonna whisper into your ear of soil." (Matitiahu 1988: 9)
}

12 All the poems, if other translator is not mentioned, are translated by Agnieszka AugustZarębska. I would like to thank Ewelina Topolska for valuable remarks concerning the final version.

13 Some of the poems analyzed here have been already discussed in a different context. See: (August-Zarębska 2013; 2015; 2016). 
Another poem, Enflamada [Inflamed] from the volume Matriz de luz [Matrix of light] written probably soon after, alludes to the sensations experienced during the visit to the cemetery:

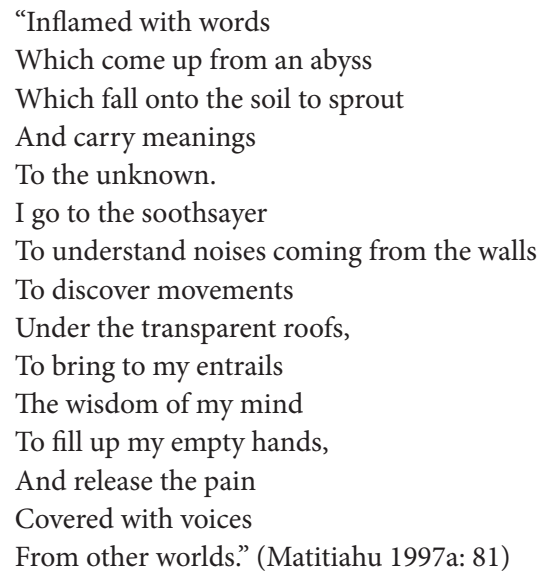

The term 'Ladino' does not appear at any point in this emotional poem. However, the author employs a metaphorical image of "words coming up from an abyss", an abyss being a dwelling place of the dead. The words "fall onto the soil to sprout", they "carry meanings to the unknown". The author seems to hear them and tries to understand and clarify them. She feels them inside, it is a gut feeling, but also beside her, as if they lived with her at home (reference to the walls). Getting in touch with these voices entails a need to open up and welcome the unknown, which, in spite of filling the void left by her mother, does not soothe the author; on the contrary, it brings more pain. The poem depicts a situation in which the persona opens up for a dialogue with the past, and the past itself starts to speak ("words... from an abyss", "noises coming from the walls", "voices from other worlds"), demanding to be understood, and ultimately to be expressed with words. ${ }^{14}$ One can assume that these voices resound with the language of the author's ancestors, Ladino. Leaving aside the question of linguistic code, is the

14 It is not the only poem by Matitiahu where she talks about sensing voices and shadows. One has an impression these elements are embedded in her mental image of home, which is further proved by the the following fragments: "In the rooms/ memories were locked/ muted voices/ start to scream..." (Matitiahu 2001: 30); "In the evening/ to know how to be with you/ in the tightness of the night/ amongst the shadows..." (ibidem: 26). Sometimes getting in touch with them is abrupt and disturbing: "Suddenly, the veins of my neck/ got inflamed with voiceless cries” (Matitiahu 1992: 45). 
message of the voices understandable? The persona of the poem seems to believe so as she talks about her visit to a soothsayer. We can consider this act to mark the beginning of a hermeneutic process of understanding and opening up to the "truth of interpretation", as Gadamer puts it. It ensues from the fact that the soothsayer always gives answers, but enigmatic as they are, they require of us a further effort of interpretation before we are able to grasp the real meaning of the message. That process of acquiring understanding is simultaneously the process of self-understanding. The usual questions directed at the soothsayer, like those addressed to the oracle in antiquity, revolve around ourselves, as we look for the meaning of the events that happened, are happening or will happen in our lives (it is worth remembering that the Delphic oracle welcomed its visitors with the inscription "Gnothi seauton" - 'know thyself'). It can be assumed that in case of the analyzed poem the goal consists in understanding the past and the forming parts of the author's identity, all of which leads to understanding her own oikos.

Another poem raising the issue of a language on the brink of extinction is La memoria [Memory]. The poet depicts herself on her way to the unknown (a metaphor of a sea travel), suspended between light and darkness, existence and non-existence, sometimes tormented by strong feelings. The phrase "Time is a cut tongue" emanates despair, as she finds herself in the liminal space between a world that has irrevocably disappeared and her memory at whose bottom lie her dearest recollections. Language is the key to the memories enclosing that bygone world; still, fewer and fewer people are able to speak it, and those who do, often use it for limited, particular purposes only. Its extinction as a vehicle of literature and culture seems inevitable. An effort the poet makes to cultivate the Sephardi cultural heritage is tainted by resignation, but eventually hope prevails, which is reflected in the last two stanzas:

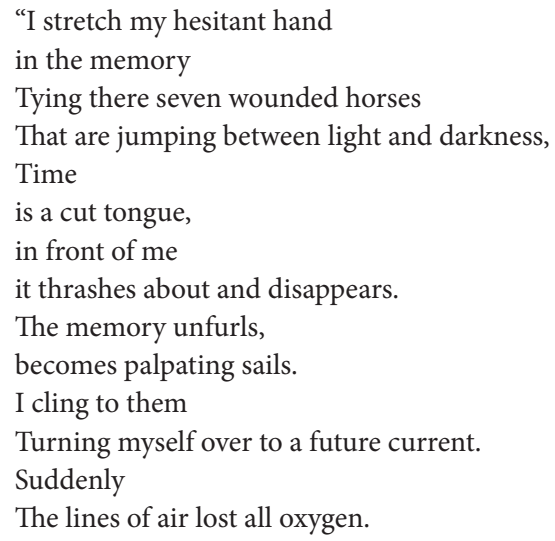




\author{
My body comes \\ And weaves a net \\ To hold the memory \\ In the moment of its fall." (Matitiahu 1997a: 72)
}

Our attention is called to the metaphor of seven wounded horses moving swiftly between light and darkness. It may refer to time, to its basic division into weeks (hence the number seven) whose days are filled with an acute nostalgia for the relatives who passed away, and meditation on the volatility of everything that we hold dear. Additionally, the suggestive image invokes connotations with shiva (Hebrew: שבעה, literally 'seven'), a week of intense mourning after the death of first-degree relatives. During this period the feelings caused by the loss are at its highest and their expression is regulated by specific norms. ${ }^{15}$

Just like the poems analyzed previously, Memory makes reference to the period after Matitiahu's mother's death, but also after the visits to Greece, the dwelling place of the Sephardi community for centuries. Passing of her relatives who remembered the atmosphere reigning in this communities, as well as being confronted with the void caused by the Holocaust at the places previously brimming with Jewish tradition and people foster a change of her perception of herself, influencing her personal and literary life (see Morales 2005: 12). She felt a pressing need to safeguard the memory of the language of her ancestors, as well as the memory of the world and culture that manifested itself via this code ${ }^{16}$ Moreover, she realized her vocation to prolong the existence of Ladino, mainly through poetry. According to Shmuel Refael, this step required a considerable courage, as it supposed creating new expression tools in a language whose

15 For example mourners should stay indoors, sitting on low stools or even on the floor, as was the custom in Thessaloniki, where the floor used to be covered with a black textile. It was also customary to turn the household mirrors toward the wall. Close relatives do not wash or cut their hair, men do not shave. They do not eat meat or drink wine, as well as they do not indulge in pleasurable activities. Other relatives call upon the mourners to console them. In the Turkish-Balkan diaspora the visitors were in charge of bringing meals to the bereaved. Moreover, Kaddish is recited every day (see Unterman 1989: 201; Molho 1950: 198-199).

16 Matitiahu carries out this self-imposed task through multiple initiatives aimed at maintaining Judeo-Spanish alive and spreading knowledge about it. To name a few, she participated in creating broadcasts in Ladino for the radio Kol Israel, she researched Judeo-Spanish press published in Thessaloniki before WWII and together with her son Jack co-authored a movie about the Spanish roots of the Sephardi community. 
natural evolution came to a halt both on the level of everyday communication and literary expression. ${ }^{17}$

The author comments upon her search for poetic words in Ladino in the piece titled Las palabras [Words]. She writes:

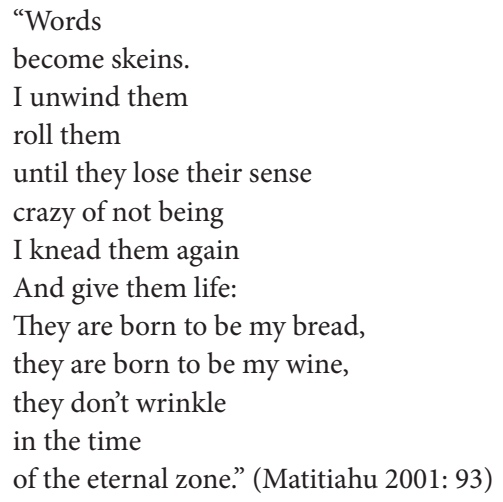

Let us pay attention to the fact that the process of finding adequate Ladino words is depicted through metaphors of such household chores as weaving and kneading. ${ }^{18}$ On the one hand the woman molds, shapes words, but on the other hand they become as necessary for her as bread and wine. These simple products evoke an image of a traditional, unsophisticated home-made meal. Additionally, in the context specific of the Jewish culture, they may be treated as a reference to the religious rules that must be observed on various occasions, especially Sabbath, when challah and blessed wine are consumed, the latter playing an important part in the rituals of kiddush and havdalah that respectively open and close the festive time (Pecaric 2011). Also during Passover it is required to consume unleavened matza and four glasses of wine distributed at fixed moments of a special dinner, seder. In that sense, bread and wine, employed in the poem as a metaphor of language, make reference to the order and well-being ensuing from a predictable dynamic of everyday affairs, ruled by cycles and repeatability, its monotony broken from time to time by the cathartic power of the festive days. If

17 Matitiahu did not limit herself to imitating the Sephardi literary tradition and nostalgic recollections of the past, although such strategy could possibly contribute to her gaining more popularity and readers (Refael 2001: 13-14).

18 It was an unquestioned custom among housewives in Thessaloniki to knead bread dough on Friday morning. This bread was eaten not only on the Sabbath, but also throughout the week. (Molho 1950: 151). 
working with language can be compared to household chores, and words become self-made bread and wine that accompanies it, if giving meaning to words and maintaining that meaning can be compared to efforts typical of running a house, does not Ladino become a synonym of oikos?

Regarding the second oikological aspect mentioned in the introduction, namely home as a palimpsest, let us quote a fragment of Gabriela Marszołek's article The Hearth of the Earth. Oikologically on the Liquidity of Place:

"Home is not a real, tangible place where we could hide to shut out the outside world, but it is a memory of the place where we grew up, and out of which we grow later, and it ceases to be a place that encloses us to become a place we enclose in our mind. However, such memory of a place is never fixed. It gets worn out, fades, becomes changeable, inexact, fragmentary, it grows out of the world [...]." (Marszołek 2011:24)

Marszołek speaks about our multi-layered and liquid notion of home, and in that sense it may be considered palimpsest-like. However, in the case of Matitiahu we can find different associations. First, a deeper sense is discovered if we take into account the historical context of the home, not only individual places where a person resided. Adopting this perspective, oikos may be found in a house, district or a city where one's parents or grandparents had lived long before I was born. Second, home is not necessarily a house with its residents, but it has a broader meaning of a locus where one feels 'at home. This feeling may be created by language, culture and experiences, either the decisive ones, or the ones resulting from an everyday dynamics of the community with which one identifies. The metaphor of home as a palimpsest suggests that the layers composing it do not cover the previous ones completely. We can discern traces of the previous layers, just as the oikological cultural sphere is still perceptible under many other layers of signs.

Thus Matitiahu's oikos comprises different places. She clearly tries to integrate the experience of her present home with the experiences and memories of previous ones, especially the place where she was raised, but also the one in Thessaloniki, where her mother spent her childhood. Memory helps the author to observe glimpses of other, bygone places under the surface of the present. In the poem Torno a mi kaza [I'm Coming Home] the author writes: "I see my home again/ a bulk of my life is showing through" (Matitiahu 1988: 31), whereas in another poem, Recodro [Recollection], she says:

"The past unfurls

like sails in my eyes.

A blind hand

is groping and pointing out..." (Matitiahu 2001: 30) 
In the fragment quoted above the "blind hand" evokes an image of groping about in the dark. Just as a blind person navigates through space mainly thanks to touch, similarly the persona discovers traces of her oikos - on the one hand visiting places connected with her family, on the other "touching" the past with her thoughts. That leads her to understanding better her own being-inthe-world. Rediscovering the meaning of her memories and interpreting them from a new perspective acquired as a result of fresh experiences, she integrates them in her horizon of self-understanding. The horizon amplifies for example during the journeys, when she sees, touches and in a sense absorbs the places important for her. The poem La kaza de mi chikez [My Childhood House] talks about her first stay after many years at her childhood home in Tel Aviv:

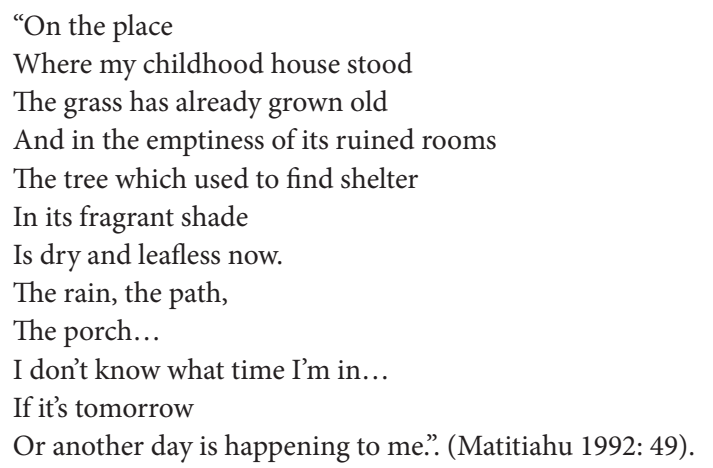

The open ending of this poem confirms that the past described by the persona is not completely closed, as it continues shaping her present. The broadly understood heritage of her family home exerts influence upon and must be included in the experience of her oikos.

In a different poem, En las kayes de Athena [On the Streets of Athens] that heritage was depicted as a suitcase that accompanies the author along her way through life:

"In the streets of Athens

I carried the invisible suitcase of my childhood

It held names, colors and scents

Which were drawn from my memory like letters.

The spouts released by the fountain

In "Homonia Square"

Merged with sounds of the language

That came back to me amid the memories of my home." (trans.: Balbuena 2016: 72-73). 
In Athens and Thessaloniki Matitiahu moves according to a mental map whose draft is based on the stories told by her parents. She looks for the names of streets mentioned by them, putting an imagined topography over a real Greek city. She acts as if she was "recreating a cognitive map of her mother" (Refael 2012: 331), which is why "her poems may be considered a journey to [...] some regions of the memory of her mother" (ibidem: 330). In Thessaloniki Matitiahu herself comments on this topic:

"I walked hurriedly

Along the sidewalks of Thessaloniki

A spell pushed me onto the streets

Known by my childhood imagination." (Matitiahu 1988: 19).

There is an important moment when she manages to find a house owned formerly by her grandfather. Matitiahu dedicates a separate poem to this extraordinary event, testifying to the strong feelings she experienced:

"(On the street where my mother grew up)

The street seemed to swell with my deep feelings,

I was walking and looking for my old name.

Afternoon shadows

started to descend over the houses.

The closed windows seemed to enter

Into a silent war with the bygone times.

Among the memories my mother sowed in me

I suddenly saw the house shrink

Till it touched the ground of the courtyard

where the voices from the past still echoed in the air.

And I heard a name resounding

Like a bell

swinging in time and saying.

<<Thesaloniki, odos theoienos Harisis 59>>" (Matitiahu 1988: 17)

The appearance of the courtyard, a kind of epiphany described in this poem becomes possible thanks to saying its Greek address aloud. This act opens access to the past, initiates an alternating movement between two time dimensions. Just as was the case with some previously analyzed poems, the contact with the past is connected with hearing voices that "echoed in the air".

In Kurtijo kemado (Matitiahu 1988: 25), a poem describing a dream and included in a homonymous book, again we encounter an image of a courtyard (kurtijo). In Matitiahu's poetry it usually represents everyday Sephardi life and social bonds customary among neighbors. However, in this particular poem it also becomes a symbol of the whole Judeo-Spanish and Greek past of the author's 
family and community marked by the Holocaust. The persona confesses her urge to escape a recurring, nightmarish vision of a burnt house, that keeps calling her through enigmatic, silent signs. This symbolic image communicates the pain and effort inherent in discovering one's history, but at the same time an imperative of a complete commitment to understanding one's cultural identity.

A continuation of this trope is to be found in a volume published four years later-Alegrika. It comprises poems in which the traditional Sephardi courtyard, typical of pre-war Jewish districts in the Turkish-Balkan cities, is imaginatively brought back to life as the space and fills with people. They emerge from oblivion together with the objects, colors, smells and sounds that formed part of their surroundings. Each character is portrayed through his or her unique characteristics, gestures or behaviors. And thus we meet tia Dudun - cat feeder; tia Diamante singing traditional Ladino songs; tio Shabtay drowning his sorrows in ouzo and retzina; Yudachi Bahar whispering his prayers; a hard-working washer-woman Sunhula; garlic-smelling tia Ester who shouts at children in fits of anger; and, last but not least, a nameless mother of a large family appearing in the poem Las paredes del tiempo [Walls of Time]. Thus, we are offered a section of the bygone Sephardi world with its homes and courtyards located in Thessaloniki or Smyrna, memories of which are cultivated by the nostalgia-ridden author.

Another layer of the palimpsest, the cultural one, leads Matitiahu to direct her steps towards Spain, the mythical Sefarad, whose city León was a place of origin of her ancestors. During the travel she enjoys the sound of Spanish, perceiving in it distant echoes of the Ladino language. She decided to visit Spain as, in her opinion, her feelings for this land were transmitted to her with her mother's milk; and so she sets on a journey:

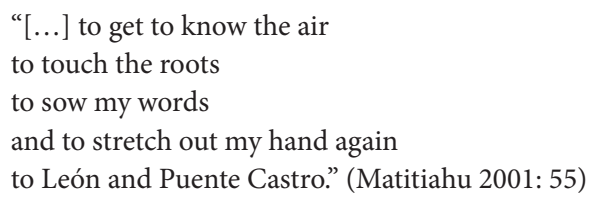

In a sense, she goes in the contrary direction to the Jews expelled from the Iberian Peninsula in 1492. She reaches out, touches stones, stops at the place that used to host a Jewish district Puente Castro, destroyed in the 12th century. That is where she can contemplate the depth of her roots:

"I, like a leaf

that came with a gush of poetic wind, descended to the nest of roots and branches to find the past 
of the forefathers of my forefathers.

In Puente Castro in León." (Matitiahu 2001: 52)

The reference to a nest is significant in this poetic picture, as young birds have to leave their temporary home when they mature and set on a journey to create their own nests, their own homes. This image is reinforced by the tree metaphor (the roots, trunk, boughs), in which the author perceives herself as a leaf. Fragile and vulnerable to the wind, the leaf may also represent the lot of her family and community, vulnerable to the wind of history. It is not accidental that the book comprising these verses is titled Vagabondo eternel [Eternal Vagabond].

The aim of the above analysis was to show the oikological dimension of Margalit Matitiahu's poetry. There were two claims underlying this assumption: first, it is possible to apply the oikological perspective to the literary, cultural and biographical phenomenon that the author's art and professional activity constitutes; second, that her poetry is replete with topics and associations that are significant from the point of view of oikology as defined in the introduction. The examples quoted and analyzed in the article seem to appositely exemplify the initial assumption. The choice to use a moribund language as a poetry code may be understood as an oikological decision, and the subject matter, as well as the dynamics of Matitiahu's texts are marked by the search of a sphere of home a sphere of profound and mutual belonging (as we pertain to it and it pertains to us). The author finds this sphere in the palimpsest-like memories of her childhood home, the dwelling places of her ancestors, as well as the culture, language and history of the community she originates from. An important role is played by the themes of running a household, everyday efforts to maintain it on a satisfactory level, or, in other words, by the efforts directed at keeping the author's home, her oikos, alive.

\section{References}

Augé, Marc (1995): Non-Places. Introduction to an Anthropology of Supermodernity. London \& New York.

August-Zarębska, Agnieszka (2013): The Representations of kurtijo and Their Function in Contemporary Judeo-Spanish Poetry. In: Kątny, Andrzej/Olszewska, Izabela/Twardowska, Aleksandra eds.: Ashkenazim and Sephardim: A European Perspective. Frankfurt am Main, 245-268.

August-Zarębska, Agnieszka (2015): El viaje y el redescubrimiento de la identidad sefardí en la poesía de Margalit Matitiahu [Journey and Rediscovery 
of Sephardic Identity in Margalit Matitiahu’s Poetry]. In: Estudios Hispánicos 23, 184-194.

August-Zarębska, Agnieszka (2016): La figura de la madre en la poesía de Margalit Matitiahu [The Figure of Mother in Margalit Matitiahu's Poetry]. In: Díaz Mas, Paloma, Martín Ortega, Elisa eds.: Mujeres sefardíes lectoras y escritoras, siglos XIX y XXI. Madrid- Frankfurt am Main, 303-317.

Balbuena, Monique R. (2016): Homeless Tongues. Poetry and Languages of the Sephardic Diaspora. Stanford.

Bauman, Zygmunt (2000): Liquid Modernity. Cambridge.

Benbassa, Esther, Rodrigue, Aron (2004): Historia de los judíos sefardies. De Toledo a Salónica. Madrid.

Díaz-Mas, Paloma (1986): Los sefardíes. Historia, lengua y cultura. Barcelona.

Fleming, Katherine Elizabeth (2008): Greece - a Jewish History. Princeton-Oxford.

Gadamer, Hans-Georg (1980): Logos and ergon in Plato's Lysis. In: Gadamer, Hans-Georg: Dialogue and Dialectic. Eight Hermeneutical Studies on Plato. New Haven and London, 1-20.

Harris, Tracy K. (1994): Death of a Language. The History of Judeo-Spanish. Newark, London \& Toronto.

Harris, Tracy K. (2001): The State of Ladino Today. In: European Judaism 44/1, 51-61.

Kadłubek, Zbigniew (2013): Oikologia (inkarnując wiarę) [Oikology (Incarnating the Faith)]. In: Sławek, Tadeusz, Kunce, Aleksandra, Kadłubek, Zbigniew: Oikologia. Nauka o domu [Oikology. Science of Home]. Katowice, 168-190.

Marszołek, Gabriela (2011): Domostwo ziemi. Oikologicznie o płynności miejsc [The Hearth of the Earth. Oikologically on the Liquidity of Places]. In: Anthropos? 16-17, 23-29 [http://www.ojkologia.us.edu.pl/artykuly/95/ gabriela-marszolek-domostwo-ziemi-oikologicznie-o-plynnosci-miejsc/ access on the 23-11-2014].

Matitiahu, Margalit (1988): Kurtijo kemado [Burnt Courtyard]. Tel-Aviv.

Matitiahu, Margalit (1992): Alegrika. Tel-Aviv.

Matitiahu, Margalit (1997): Matriz de luz. Poesía en judeo-español. Tel-Aviv.

Matitiahu, Margalit (1997a): Vela de la luz. León.

Matitiahu, Margalit (2001): Vagabundo eterno (Vagabondo eternel) [Eternal Vagabond]. León.

Matitiahu, Margalit (2001b): Lengua, creación y prensa en ladino en la comunidad judía española en Saloniki 1492-1942. In: Vagabundo eterno (Vagabondo eternel). León, 107-116. 
Molho, Michael (1950): Usos y costumbres de los sefardíes de Salónica. Madrid-Barcelona.

Molho, Rena (2013): Salonica, a Metropolis to the Jewish Diaspora. In: Kokot, Waltraud/Giordano, Christian/Gandelsman-Trier, Mijal (eds.): Diaspora as a Resource. Comparative Studies in Strategies, Network and Urban Space. Berlin, 289-303.

Morales, Carlos (2005): Margalit Matitiahu, y el encuentro con la "luz". In: Matitiahu, Margalit: Asiguiendo al esfuenio. Ourense, 9-16.

Pecaric, Sacha (2011): Wstęp [Preface]. In: Grunfeld, Isidor: Szabat [Shabbat] Cracow, 5-18.

Pfeffer, Anshel (2013): Greece Finally Commemorates the Destruction of Thessaloniki's Jewish Community. In: Haiaretz 20.03.2013, http://www.haaretz. $\mathrm{com} / \mathrm{jewish} /$ features/greece-finally-commemorates-the-destruction-ofthessaloniki-s-jewish-community.premium-1.510554, [access: 25-11-2014].

Red de juderías de España - Caminos de Sefarad. León, www.redjuderias.org/ google/google_maps_print/leon-es.html, [access: 25-11-2014].

Refael, Shmuel (2001): Modernismo en el judeo-español. In: Matitiahu, Margalit: Vagabundo eterno (Vagabondo eternel). León, 12-15.

Refael, Shmuel (2012): The Geography of the Memory: The Representation of the Pre-Holocaust Salonican Jewish Community in the Post-Holocaust Sephardic Poetry. In: eHumanista 20, 321-333,

http://www.ehumanista.ucsb.edu/volumes/volume_20/pdfs/articles/ monographic\%20issue/16 \%20Refael.v20.pdf, [access: 20-11-2014].

Reut, Maria (2010): Narracja i tożsamość [Narration and Identity]. Wrocław.

Ricoeur, Paul (1992): Oneself as Another. Chicago.

Romero, Elena (1992): La creación literaria en lengua sefardí. Madrid.

Sławek, Tadeusz, Kunce, Aleksandra, Kadłubek, Zbigniew (2013): Oikologia. Nauka o domu [Oikology. Science of Home]. Katowice.

Unterman, Alan (1989): Żydzi. Wiara i życie [The Jews. Their Religious Beliefs and Practices]. Łódź.

Węclewski, Zygmunt (1929): Słownik grecko-polski [Greek-Polish Dictionary]. L'viv. 

Katja Šmid

\title{
Sefer ha-Berit in Ladino: Adaptations and Translations of a Hebrew Best-Seller for the Sephardi Reading Public ${ }^{1}$
}

\begin{abstract}
Sefer ha-Berit was published for the first time in Hebrew by the Ashkenazi author Pinhas Hurwitz Eliyahu (Vilna, 1765 - Cracow, 1821) in Brno, Moravia in 1797. Since then it has been published in numerous editions in Hebrew and a few in Yiddish and Ladino. The aim of this article is to study translations and adaptations of this relevant 18th-century rabbinic work on science, Kabbalah and ethical guidance (musar) in Ladino. Yiṣhaq Bekor 'Amarachi and Yosef ben Meir Śaśon were the first Sephardi authors inspired by Sefer ha-Berit, who incorporated some of its most relevant moralistic and scientific chapters in two popular Ladino works Sefer Darke ha-Adam and Sefer Musar Haśkel (Salonika, 1843, 1849, and 1892). The first translation of Sefer ha-Berit was carried out by Hayyim Abraham Benveniste Gategno (Salonika, 1847), and was revised, updated, and republished as part of the Ladino periodical literary supplement entitled Berakah ha-Mešulešet o Las Tres Luzes (Salonika, 1881 and Constantinople, 1900).
\end{abstract}

Keywords: Judeo-Spanish/Ladino/Judezmo Literature, Rabbinic Musar Literature, Science, Sefer ha-Berit, Berakah ha-Mešulešet o Las Tres Luzes, Sefer Darke ha-Adam, Sefer Musar Haśkel

1 I would like to dedicate this article to Prof. David Ruderman, who asked me about the Ladino translations of Sefer ha-Berit during my research stay at the University of Pennsylvania in 2011. Although I needed some years to come to the first comprehensive conclusions because of the abundance of material, I was glad to learn that the Sephardi authors were also fascinated by this book and that they succeeded in selecting the very best of its content for the Sephardi reading public. This article was initiated in 2013 during my postdoctoral research project at the University of Salamanca in Spain, thanks to the financial support by the Cátedra de Altos Estudios del Español of the Campus de Excelencia Internacional / Studii Salamantini; and has been concluded in the framework of two projects: "Ginze Sefarad (2013-2015): Edition and Study of Historical Documents and Hebrew and Halakhical Texts" (Ref. HAR2012-34338, Spanish Ministry of Economy and Competitiveness), and Jewish Cultures across Mediterranean Europe (CSIC-UCM, 2017). 


\section{Sefer ha-Berit in Hebrew}

Sefer ha-Berit [The Book of Covenant] by Pinhas Hurwitz Eliyahu (Vilna, 1765 Cracow, 1821) was published for the first time in Hebrew in Brno, Moravia, in 1797. As recently noted by Ruderman (2014: 123-129: Appendix 1), approximately forty editions have been published in Hebrew, Yiddish and Ladino, but despite that, up to now, we lack a critical edition of this book in English or any other European language. One of the reasons for the popularity of Sefer haBerit - written as a commentary to the Šäare Tešubah by cabbalist Hayyim Vital (Safed, 1543 - Damascus, 1620) - is undoubtedly the diversity of its contents, including different subjects concerning science, Kabbalah, and ethics (see, for example, Harris 1982: 39-53; Robinson 1989: 275-288; Fontaine 2006: 223-233; 2007a: 157-181; 2007b: 244-268; Brown 2013; and Ruderman 2014).

The first part of the book, called Ketab Yošer [A Righteous Composition], deals with cosmology, astronomy (chapters 1-4), the four elements, geography, meteorology (5-10), minerals, plants, animals, man (11), mineralogy (12), botany (13), zoology (14), the animal soul, the vegetative and animal soul in man, psychology, embryology, anatomy, (15-16), the rational soul, the intellect and different types of knowledge (17-21) (Hurwitz 2014: 74-491; see also Fontaine 2006: 223-225; and Ruderman 2014: 135).

The second part of the book, entitled Dibre Emet [Words of Truth], examines the souls of the Israelite (1), good and bad attributes (2), the Divine commandments (3), love and fear (4), the righteous and the pious person (5), prophecy (6), the Holy spirit (11-12), love of one's neighbor (13), and love and joy (14) (Hurwitz 2014: 492-736). Because of the diversity of topics and the detailed descriptions of contemporarily invented scientific instruments, such as the barometer, thermometer, air pump, helium balloon, smallpox vaccine, among others, Sefer ha-Berit has on several occasions been characterized as a sort of encyclopedia of the sciences (Robinson 1989: 275-288; Fontaine: 2006: 223224; Ruderman 2002: 126-131, 2012: 221, and 2014: 12, 14, 36, 39-40, 45-56).

As modestly expressed in the first introduction to the book, Hurwitz (2014: 39) addresses common readers who can learn something new from his book, clarifying that his purpose is not to speak to the learned and knowledgeable Jewish reading public. Hurwitz himself was working hard on the distribution and marketing of his precious book and was very successful in his role as a salesman and entrepreneur (Ruderman 2012: 238-239; and 2014: 30-39). His

2 From all the Hebrew editions of this book, I refer to Hurwitz (2014), recently published by Hen Le-Dodi Publishing House in Jerusalem. 
best-selling book, a refined combination of Kabbalah, science and morality, ${ }^{3}$ reached a wide Jewish readership in Europe and beyond. Among others, Ruderman (2014: 90-114: Chapter 6) studies the reception of the Sefer ha-Berit in Hebrew in different Ashkenazic communities and mentions that the book quickly became very popular also among the Sephardim, both Ladino speakers in the Ottoman Empire as well as Arabic speaking Jews from the Middle East and North Africa.

\section{Ladino Moralistic Works Inspired by Sefer ha-Berit}

Yiṣhaq Bekor 'Amarachi and Yosef ben Meir Śaśon were the first Sephardi authors inspired by Sefer ha-Berit. They composed two popular moralistic works in Ladino, Sefer Darke ha-Adam and Sefer Musar Haśkel (Salonika, 1843, 1849 and 1892), incorporating into them some of the most relevant scientific and moralistic excerpts from Sefer ha-Berit, combined with other traditional and contemporary Hebrew sources.

Through these moralistic works in the vernacular, a large part of the Ladino speaking Sephardim (who aside from certain exceptions, mostly the rabbinic elite, did not read works written in Hebrew), settled in the Ottoman Empire and other places in the Mediterranean, had the opportunity to receive information for the first time about Sefer ha-Berit.

"The translator of the book says: You shall know, my brethren, that these two chapters I wrote are [taken] from Sefer ha-Berit, second part, chapter thirteen, entitled love of one's neighbor, meaning, love of fellow men. As I saw these blessed and wise words, I wrote them in Ladino to privilege those who don't understand the sacred tongue." ${ }^{\prime 4}$ ('Amarachi/Śaśon Sefer Darke ha-Adam 1843: 71b)

Yiṣhaq Bekor 'Amarachi (Salonika, ?-?) was a prolific translator who translated several works from Hebrew into Ladino: Sefer ben ha-Melek ve-ha-Nazir (Salonika, 1849), the famous story of Barlaam and Josaphat; Keter Šem Tob (Salonika, 1850),

3 Ruderman (2012: 233 and 2014: 12, 60, 101, 107) describes it as pious science.

4 All translations from Ladino into English are made by the author of this article. For the transliteration from Hebrew Rashi to Latin letters I follow the system established by Hassán (1971: 1235-1263, 1978: 147-150, 1988: 127-137, and 2008: 119-136).

Lad. "Diće el treśladador de el libro: Sabrás, mi hermano, que estos dos peraquim que te escribí son de el Séfer ha-Berit, hélec šení, maamar treche, que se llama ahabat re'im, quere dećir amor de compañeros; que siendo que vide sus palabras tan bendichas y de cencia lo mirí de escribirlo en ladino para ser źojé a_los que no saben entender en lašón hacodeš.” 
a biography of the English Sephardic philanthropist Moses Montefiore, written by Abraham Menahem Mendel Mohr (Lemberg, 1847); Máasé haarets (Salonika, 1850), a work on geography, written by Rabbi Yehoseph Schwartz (1804-1868); Tiferet Yisrael (Salonika, 1850), a story about the family Rothschild, written by Abraham Menahem Mendel Mohr (Lemberg, 1843); Sefer Šebilé 'olam (Salonika, 1853), a book on geography, written by Samson ha-Levi Bloch (Zolkiew, 1822 and 1927); Hut ha-Mešulaš (Salonika, 1857), Abraham Menahem Mendel Mohr's biography of Napoleon III (Lemberg, 1853) (cf. Romero 1992: 204; Bunis 2002: 121; Lehmann 2005: 7; and Riaño 2005: 413, 419).

'Emanuel (1986: 242) and Lehmann (2005: 7) mention also 'Amarachi's involvement in the printing business. He operated a printing press in Salonika between 1845 and 1847 and imported Hebrew letters from Vienna and Livorno. Among the books published by 'Amarachi were parts of the Zohar (1845), and a Ladino translation of Hurwitz's Sefer ha-Berit (1847).Yosef ben Meir Śaśon (?, 1810 - Belgrade, 1862) is, according to an 1856 register of Jews in Belgrade, commented by Lebl (2001:107-108), listed as a 46-year-old Rabbi, who had a Turkish passport, and who settled in the Serbian capital where he served as a Rabbi from 1851 to 1862. Śaśon is also the author of Sefer Zoveah Todah (Belgrade, 1860), a 105-folio guide of Jewish laws for animal ritual slaughtering in Judeo-Spanish. He learned to become a ritual slaughterer in Salonika where he lived for 35 years (Śaśon 1860: 21a). In the introduction to his book, signed as Rafael Yosef ben Saśon, we learn that in 1859 he survived a serious illness and added to his name Yosef a new one, Rafael (Hb. 'God has healed') (Ben Śaśon 1860: 5b; Šmid 2016: 185).

\subsection{Sefer Darke ha-Adam}

Three editions of Sefer Darke ha-Adam [Book of the Ways of Man] printed in Hebrew Rashi script, and published in Salonika in a period of only 50 years, testify to the success this work had among the Ladino readership in the mid-19th century.

The first edition of Sefer Darke ha-Adam (92 folios), signed by Yiṣaq Bekor 'Amarachi and Yosef ben Meir Saśon, was published in 1843 in the printing house of Saadi ha-Levi in Salonika and typeset by Abraham Jahon and Hanok Pipano.

In the second edition from 1849 (62 folios), published in the printing house of Daniel Fragi by Šabbetay 'Al'aluf and Yiṣhaq Jaḥon, we find the name of Yiṣhaq Bekor 'Amarachi as the only author.

The last edition of this book from 1892 (160 pages) includes the names of both authors, just like the first one, and was published posthumously in the printing 
house Eș he-Hayyim with help of Šelomo Aharon Yeni, and typeset by David b. Yiṣhaq Sa'adi. This edition consists of Sefer Darke ha-Adam (pp. 1-123) and a selection of moralistic texts in prose and para-liturgical compositions in verse (pp. 124-160), as announced with the following text: "Seeing that the book Darke ha-Adam contains few folios, I translated for you a little bit of moralistic literature in alphabetical order"s ('Amarachi/Śaśon Sefer Darke ha-Adam 1892: 124).

Darke ha-Adam is an original Ladino book with moralistic and entertaining purposes (see Romero 1992: 113; Lehmann 2005: 92, 96, 103-104, 121-122, 156, 177-181, 189-192, 196, 206; Muñoz Molina 2012: 145-146, 149, 153-155 and 2014: 125-134), inspired by three Hebrew works, Sefer ha-Berit by Pinhas Hurwitz (Brno, 1797), Seder ha-Dorot by Yehiel Heilprin (Karlsruhe, 1768) and Šebet Yehudah by Šelomo Ibn Verga (Adrianople, 1550) of moralistic, scientific and historical content: "Most of its words are from Sefer ha-Berit [...] and a little bit of morality and a few stories from Seder ha-Dorot and Šebet Yehudah"6 ('Amarachi/Śaśon Sefer Darke ha-Adam 1843: cover page).

From a total of six chapters of Sefer Darke ha-Adam, 'Amarachi and Śaśon refer to Sefer ha-Berit as a source in four of them (1,3,4 and 5).

Chapter 1 (fs. 1a-14a) brings a very brief paragraph (15 lines in Rashi script) about the importance of air in the atmosphere for human beings (f. 6b).

Chapter 3 (fs. 25a-29b) describes some fascinating episodes regarding the discovery of the New World (see Lehmann 2005: 189-190, 195-196; and Šmid 2017: 261-278), inspired by Sefer ha-Berit and Sefer Dibre ha-Yamim (Sabbioneta, 1554), a chronicle written by Yosef ha-Kohen, according to Jacobs (2004: 69), dealing "with gentile history in which relatively few instances of the Jewish past - mainly massacres and persecutions - are included", which in its second part speaks about the discovery of America, among other things (Jacobs 2004: 70, 76).

Chapters 4 (fs. 29b-52a) and 5 (fs. 52a-72a) incorporate one of the most powerful moralistic chapters from Sefer ha-Berit (13) on loving one's neighbor, love and friendship, adapting this universal moralistic topic for Ladino readers for the very first time. This material gave translators the opportunity to speak about love and hatred in many different contexts. As an example, in the following passage

5 Lad. "Mirando que el libro Darjé haadam contiene pocas hojas te treśladí un poco de musar 'al séder a'b."

6 Lad. "El rob de sus palabras son de el Séfer haBerit [...] y un poco de musar y unos cuantos ma’asiyot de el Séder haDorot y de el Šébet Yehudá." 
we read a discussion about the bad opinion Sephardim have of Ashkenazim and vice-versa:

"I am amazed about the bad habit present in these generations, most of the people say that people from this city are mean and liars, and the people from the other city say the same about those of the first city. And there is another bad attribute: most of the Sephardim say that Ashkenazim are bad in their deeds and they abhor them, and especially if the Sephardim and Ashkenazim live in the same city, there the enmity is greater. And the Sephardim say that they are from the big family of the tribe of Yehudah, and the Ashkenazim say of the Sephardim the contrary, that they are bad in their deeds and the enmity is much bigger than the abhorrence one feels toward his fellow." ('Amarachi/Śaśon Sefer Darke ha-Adam 1843: 69b)

'Amarachi and Śaśon are the first Sephardi authors who, in Sefer Darke ha-Adam, a didactic, moralistic and entertaining work, offer some of the most fascinating excerpts from Sefer ha-Berit. As pointed out by Lehmann (2005: 189-192), they introduce, probably for the first time, scientific knowledge and historiographic topics taken from general, non-Jewish history, and incorporate them into the musar Ladino literature, an important novelty in the Judeo-Spanish rabbinic literature in the mid-19th century.

\subsection{Sefer Musar Haśkel}

Sefer Musar Haśkel [Moral Lesson] also came out in three editions in Salonika, but always signed by Yosef ben Meir Śaśon, as the first author, and Yiṣhaq Bekor 'Amarachi, as the second. The first edition (92 folios) was published in 1843 partially (fs. 1a-48a) in the printing houses of Eliyahu Farachi and partially (fs. 48a92b) in the Sa'adi ha-Levi Aškenazi's print in Salonika 'Emanuel (1986: 242). The second one (69 folios) came out in 1849 from the printing press of Daniel Fragi by Šabbetay 'Al'aluf and Yiṣhaq Jahon, and the third one (151 pages) in 1892 from the printing house of Šelomo Aharon Yeni by Yehuda b. Abraham and David Bekor Yiṣ̣aq.

7 Lad. "Muncho me maravillo sobre el minhag el negro el este que hay en estos dorot en el rob de la ĝente que dićen: 'La ĝente de tala civdad son negros y mentirośos'; y la ĝente de la otra civdad dićen lo propio por esta civdad. Y hay otra midá más negra que el rob de los sefardim dićen por los aškenaźim que son negros en sus ma’asim y los aḅorecen, y bifrat si moran en una civdad sefardim con aškenaźim es la nemistad más grande. Y los sefardim dićen: 'Siendo mos-otros somos de mišpahá grande de el šébet de Yehudá, y los aškenaźim dićen por los sefardim a_revés que son negros en sus ma’asim y la nemistad la esta es muncho negro, más de la aboreción que tiene con su haber." 
It seems that Sefer Darke ha-Adam and Sefer Musar Haśkel complement each other, and, as noted in the bibliographical description of some copies I dealt with, in the case of the first and the second edition they were bound together. In the case of the first edition of Sefer Musar Haśkel (1843), we find a reference to the content from Sefer Darke ha-Adam "As we already noted in Darjé haadam [...]"8 (f. 64b), which indicates that Darke ha-Adam was published earlier. On the other hand, the third edition provides us with interesting information about the publication of Sefer Musar Haśkel first, followed soon after by Sefer Darke ha-Adam, with the help of different typesetters, as already mentioned above: "We announce to the gentlemen that, with God's help, in some days we will print the beautiful book Darke ha-Adam, which contains many things on science and chastity. We hope you will not fail to help us"' (Sefer Musar Haśkel 1892: 152 [without pagination]).

Sefer Musar Haśkel is a moralistic work of varied content (Romero 1992: 113114; Lehmann 2005: 177-181, 189-193; Muñoz Molina 2012: 143-156), which opens with an extraordinary chapter on scientific knowledge, and includes some moralistic, as well as historiographical chapters, all of them based exclusively on classical and contemporary Hebrew scientific, literary and historical sources.

Musar Haśkel is heavily inspired by Sefer ha-Berit, too, and refers to it in six of its twelve chapters $(1,2,5,7,10$ and 12).

Chapter 1 (fs. 1a-4a) begins with a scientific discussion on the smallpox vaccine after the deaths caused by this disease of "more than a thousand children" in Salonika a year before, looking for rational explanations and remedies (fs. 1b-4a) (Romero 1992: 114; Lehmann 2005: 189-190).

Chapter 2 (fs. 4a-6a) cites Sefer ha-Berit among other many classical Hebrew literary sources and makes comments on moralistic issues, examining the use and abuse of one's body and soul and discussing the importance of chastity for one's physical health.

Chapter 5 (fs. 17b-27a) is of didactic and moralistic content. It gives advice on how to educate Jewish youth. It is mostly dedicated to boys, but also addresses the education of girls, to whom one of the ten recommendations is directed.

On the one hand, Śaśon and 'Amarachi give advice on health, recommending vaccinating children against smallpox, in order to prevent the disease, described in the first chapter, and to stop breast-feeding at the age of two, among others.

8 Lad. "Siendo ya aviśimos en el s' Darjé haadam."

9 Lad. "Se da aviśo a los señores, b’eH, que en pocos días meteremos en estampa el hermośo libro Darjé haadam que contiene munchas cośas de cencia y de castiguerio. Esperamos que non mancaréš de ayudarmos." 
On the other hand, the authors mostly speak about the education and knowledge Jewish sons should receive (languages, books, a good profession, etc.). Among the recommended readings, besides the traditional halakhic and moralistic Hebrew sources, we find books on science, in order to teach sons about the natural sciences; Sefer ha-Berit being one of the most cited in this chapter.

Chapter 7 (fs. 33a-52b), a combination of quotations from Maimonides and Sefer ha-Berit, is of moralistic content, dealing with man's soul and the power of speech.

Chapter 10 (fs. 64b-71b), exclusively of scientific content, discusses geography and meteorology (using Europe and America as examples), basic astronomy, and describes and explains eclipses of which it includes two illustrations (fs. 68a, 69a) in Musar Haśkel (Lehmann 2005: 190-193).

Chapter 12 (fs. 77a-92b), entitled Pereq hamašiah [The Chapter about the Messiah], gives an account of the various messianic movements that have disrupted Jewish history (Lehmann 2005:0), exemplified with many stories and legends (maiasiyot) about false messiahs, mainly taken from Šebet Yehudah and Sefer ha-Berit.

The use of both, traditional and contemporary Hebrew sources that Saśon and 'Amarachi quote in Sefer Musar Haśkel, are more numerous than those in Darke ha-Adam, and their combination of scientific, moralistic, and historical passages makes their rabbinic discourse diverse, innovative and unique.

\section{Translations of Sefer ha-Berit into Ladino}

\subsection{The First Partial Translation by Hayyim Abraham Benveniste Gategno}

Only three years after the first edition of Darke ha-Adam and Musar Haśkel, Hayyim Abraham Benveniste Gategno's translation of the first part of the Sefer ha-Berit in Judeo-Spanish (chapters 1-21) was printed in Hebrew Rashi letters, in two extensive volumes, in 1847, published by Šabbetay 'Al'aluf and Yiṣhaq Jahon in 'Amarachi's printing press in Salonika ('Emanuel 1986: 242). ${ }^{10}$

As its Hebrew original, the Judeo-Spanish Sefer ha-Berit also opens with Petah ha-Šäar [Opening of the Door] (fs. 1a-2b), a brief description of the content of the book, followed by two long introductions, Haqdamah rišonah [First Introduction] (fs. 3a-15b), and Haqdamah segunda [Second Introduction] (fs.

10 There are no indications about the printing house or 'Amarachi's name in either the first or the second part of the Sefer ha-Berit (Salonika, 1847). 
15b-22a) with independent pagination. The first volume starts with Petihah, a kind of prologue (fs. 1a-9a), and continues with the first chapter (starting on f. 9b). The first part of the Judeo-Spanish Sefer ha-Berit called Ketab Yošer is divided into two volumes: the first volume (fs. 1a-178b) comprises ten chapters (1-10), and the second (fs. 1a-198a) includes eleven chapters (11-21). Even if Gategno translated Hurwitz's praising words about the second part of the Sefer ha-Berit, called Dibre Emet, to the best of my knowledge, the translation of the second part of Hurwitz's best-selling book has never been published in Ladino (Romero 1992: 135-136).

\subsubsection{Translation and Printing Process of the Ladino Version}

In the first half of the 19th century, the variety of Hebrew editions of Sefer haBerit on the market (Ruderman 2014: 30-39, 123-129) caused some difficulties for Sephardi rabbis who were translating this book into Judeo-Spanish. At the end of the first volume of the Ladino translation (1847), Hayyim Abraham Benveniste Gategno adds several notes which reveal some interesting facts regarding the process of translation and printing.

The first Hebrew edition of Sefer ha-Berit (Brno, 1797), which appeared only with the initials of the author's name, was published as a pirated edition by Yosef Rośman who saw that the book was very popular (Brno, 1801) (Ruderman 2012: 222, 226-227; and 2014: 7, 123-124, 139, 144). Consequently, Hurwitz responded openly to Rośman's pirated edition with his second revised and expanded edition (Zolkiew, 1807), explaining in detail the curious publishing and selling history of his book, in two extensive introductions. After that, Hurwitz became even more concerned and careful with the distribution and the future publications of his book, trying to control completely the reprinting of his book. In the second introduction, Hurwitz gave permission to anyone who wanted to publish his book from 1818 on, under the condition that they respect some very precise instructions, expressed in 12 points, regarding its reprint. These are of special interest for the study of Jewish printing and the history of the book (Ruderman 2014: 130-134). Under point 5, Hurwitz requests that the book should be printed in one volume and not divided into two or more parts (Ruderman 2014: 130-131).

In response to Hurwitz's rigorous instructions related to the publication of his book, at the end of the first volume of the Ladino translation of Sefer ha-Berit (f. 170b) Benveniste Gategno kindly explains that it was impossible for him to follow all the 12 points, required by Hurwitz, alleging that the first part had many folios that barely fit the binding, especially because they had used thick paper, and there had been no way to publish both parts in one volume: 


\begin{abstract}
"Note to readers
that the Rabbi, author of this book, in the second introduction, says that everybody who prints this book Sefer ha-Berit should not separate the first part from the second one and says some harsh words about this. And certainly, it is not pleasing if we divide the first part into two, nevertheless, considering [the possibility] that we did not divide it, even the first part alone would have had many folios that barely fit the binding, especially because we chose thick paper. And furthermore, if the book is finely bound, it gives it more beauty and it is read with fervor and so the science is published [...]. Thus, we took courage to make a division at the end of the tenth chapter, which is around the middle of the first part, so it comes in two volumes. And with this note we inform of the main reason which the esteemed Rabbi had, who did not want us to divide his book and [we hope that] what we did will please him. And if we failed, we ask him and we request that he forgive us, because we did not do it against his will, but rather our intention was to publish the law of the esteemed Rabbi who brings it to people in Judezmo, which was the intention of the esteemed Rabbi to compose this book as he says in the introduction." ${ }^{11}$ (Sefer ha-Berit 1847, Helec rišon: 170b)
\end{abstract}

\title{
3.1.2 Omissions, or Translator's Responsibilities
}

In another note (f. 171a), Benveniste Gategno explains that in the first volume of his Ladino translation of Sefer ha-Berit (chapters 1-10), all the passages dealing with Kabbalah were omitted because - according to the translator's humble opinion - the majority of the readers would not have understood them. $\mathrm{He}$ clarifies that, first he translated and printed the first volume of the book and, afterwards, he read Hurwitz's first and second introductions, where he learned about his instructions related to the reprinting of the book. Benveniste Gategno

11 Lad. “Aviśo a_los señores

sobre que el señor hajam, patrón de este libro, en la hacdamá segunda diće que todo el que estanpa este libro Séfer haḄerit cale sea sin apartar el hélec primero de el segundo y

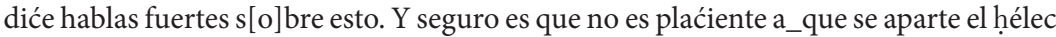
primero en dos; con todo, mirando que si no damos estajo, afilú el hélec primero solo va a_salir de muchas hojas que no lo lleva la kerijá, ande más que el papel lo escogimos sobre godrico. Y más que en siendo el libro bien recogido le_da más hermośura y toman hịáa de meldar en_él y se publica su cencia [...]. Ansí tomimos coraje a dar un estajo en el cabo de el maamar dećeno, que viene chirca en él mitad de el hélec primero, a_que venga en dos kerijot. Y con este aviśo que damos ya salimos de el 'icar de la raźón que tuvo el se’ hajam de no dejar apartar su libro y será plaćiente de lo_que hićimos. Y si mos yerimos y le demandamos y_le rogamos a_que mos enpreśente, que_no lo hićimos por haćer a_revéś de su veluntad, otro que muestra kavaná fue de publicar su ley de el se' hajam que lo trae a el honbre en el judeśmo, que esto fue su kavaná de el se' hajam de conponer este libro según que diće en la hacdamá." 
respected the author's wishes, and supplied the omitted passages related to the Kabbalah in Hebrew, without translating them into Ladino, at the end of the first volume of the book (fs. 171a-175a), indicating the corresponding chapters and pages. He also promised that he would obey the author's will and include the whole text in the rest of Sefer ha-Berit to be translated:

"Note

Until the end of chapter 10, all the places where the esteemed Rabbi, the author of this book, talked about the secrets of the Kabbalah, are omitted because, except for the esteemed cabalists, nobody understands them. And now, looking at what he says in the second introduction, that anyone who publishes the book should do it without omitting anything and says some harsh words about one who does not obey his order, therefore, from the chapter 11 on, everything that is a secret of the Kabbalah, will be published in its place as it is in the book in the sacred language. And for everything that we omitted from its place in the past, we publish it here, at the end of chapter 10, with indications, and we ask the esteemed Rabbi to forgive us; we did not do it in rebellion, but we had already printed [the book] up to here before we read the second introduction." (Sefer ha-Berit 1847, Helec rišon: 171a) ${ }^{12}$

This note gives unusual insights into the exceptional process of translating and printing Sefer ha-Berit in Ladino. It also explains that the two introductions - which have independent pagination - were printed after the first volume of the book itself.

\subsubsection{Additions, or Translator's Limitations}

The third revealing passage, written by the Sephardi translator Hayyim Abraham Benveniste Gategno, informs us about two different Hebrew editions he used while translating Sefer ha-Berit into Ladino. He began translating from the first Hebrew edition (Brno, 1797), and when he was on page 44, he received the second edition, revised and expanded by Hurwitz (Zolkiew, 1807). As he realized that there were many differences between both, he continued to translate the rest of

12 Lad. "Aviśo

Hasta cabo de maamar 10 en todos los lugares que habló el se’ hajam patrón de este libro en secretos de la cabalá los saltimos siendo no los entienden otro que los se’ mecuḅalim. Y agora viendo lo_que diće en la hacdamá segunda que todo el que estanpará este libro debe seer sin que le manque cośa y diće hablas fuertes sobre el que pasará su comando; ansí de maamar 11 endelantre todo lo_que es secreto de cabalá lo vamos a estanpar en sus lugares según está en el libro de lašón hacodeš. Y por lo pasado que ya lo saltimos de_su lugar, esto hićimos de estanparlos aquí en cabo de maamar 10 con aseñalar y demandamos de el se' hajam que mos pedrone que no lo hićimos bemered siendo hasta aquí estanpimos sin meldar la hacdamá segunda." 
the book from the second, completed Hebrew edition. In order to reflect the differences between the two editions in the first 44 pages, he translated into Ladino all the additions and modifications and listed them at the end of the first volume (175a-178b), after the above mentioned cabbalistic passages printed in Hebrew:

"Note.- From the beginning of the book up to page forty-four I translated from the first Sefer ha-Berit, and then the second [one] came to our hands and we saw that many things were added; we took the whole translation from the second [one] and the additions we found up to page forty-four, we collected them here at the end of the [first] volume, indicating everything in its place, in order not to omit anything as was the will of the esteemed Rabbi, the author of this book, as he says in the second introduction."13 (Sefer ha-Berit 1847, Heleq rišon: 175a)

\subsection{Updated Translation of Sefer ha-Berit by Rafael Yiṣhaq Ben Veniste}

Some decades later, Hayyim Abraham Benveniste Gategno's Ladino translation of Sefer ha-Berit reappeared in another Judeo-Spanish publication with the title Berakah ha-Mešulešet o Las tres luzes [Triple Blessing or Three Lights].

The first edition of Berakah ha-Mešulešet o Las tres luzes was edited by Rafael Yiṣaqa ben Veniste and published in 1881 in the printing house Eș he-Hayyim by the typesetters Moše Yảaqob 'Ayaš and Moše Yosef. It contains four different works in Judeo-Spanish, organized on every page one beneath the other, on large folio size paper: 1) Sefer ha-Berit (fs. 1a-88b);2) El rijo de la vida (fs. 1a-60b) [Manner of Life], moral work on habits regarding food, health, and good manners; 3) Bảal tešuba (fs. 1a-39b) [A Repentant], a short novel about repentance; and 4) El asolado en la izla (fs. 40a-88b) [The Lone Survivor on the Island], Daniel Defoe's story of Robinson Crusoe adapted for Ladino readers (Lazar 1999: 849-881; Borovaya 2003: 42, 63).

The second edition of Berakah ha-Mešulešet o Las tres luzes appeared in Salonika in the same year (1881), this time comprising only three works: Sefer haBerit (pp. 3-178), Ba’al tešuba (pp. 3-88), and El asolado en la izla (pp. 3-146). ${ }^{14}$

13 Lad. "Aviśo.- De el precipio de el libro hasta daf cuarenta y cuatro fue treśladado de el Séfer haḄerit primero y después mos vino a_la mano el segundo y vimos que hay pujado muchas cośas, tomimos todo el treślado de el segundo y las pujas que topimos hasta daf cuarenta y cuatro, las acogimos aquí en el cabo de la kerijá con aseñalar cada cośa ande es su lugar a_que no le manque cośa en este libro que esto es su raŝón de el se' hajam patrón de este libro según que diće en la hacdamá segunda.”

14 In the copy of the edition I used (microfiche, Hebrew books from the Harvard College Library, LA 0205-0207), the cover page is missing, therefore it is impossible to confirm the bibliographic details at the moment. 
The third edition of Berakah ha-Mešulešet o Las tres luzes, published in 1900 in the Arditi printing press in Constantinople, was edited by Eliyahu Levi ben Nahmias. His name appears on the cover page as well as in an interesting note (f. 2a) for those who want to subscribe to the publication: to contact Eliyahu Levi ben Nahmias, the distributor of newspaper El Avenir ${ }^{15}$ in Salonika. Lazar (1999: 851) explains that the publisher Eliyahu Levi ben Nahmias could not obtain the rights to publish the work El rijo de la vida (fs. 1a-60b), therefore it had to be removed.

The portion of Sefer ha-Berit included in the Berakah ha-Mešulešet o Las tres luzes is not complete: it comprises only nine chapters (1-9) of the first volume, one less than we find in the first volume of the first part of this book in Gategno's translation from 1847 (chapters 1-10). As announced in the introduction to the book, and written at the end of the publication ("Continuaremos"/ "To be continued"), the editor had the intention to publish also the second volume of the Sefer ha-Berit, but unfortunately did not succeed.

The translation of Sefer ha-Berit in Berakah ha-Mešulešet is Gategno's text from 1847, but after some decades the editors felt that they had to update the Ladino orthography so there are, among other smaller changes, slight differences in the two versions of the translation of this book. ${ }^{16}$

The inclusion of nine chapters of Sefer ha-Berit in the work Berakah ha-Mešulešet o Las tres luzes with other works, adapted for Judeo-Spanish readers, was an interesting fusion of science, morality and entertainment, offering readers educational, edifying and entertaining reading all at once. Sefer ha-Berit became popular also next to secular genres, such as the Ladino novel or the periodical press, which played an important role in the process of the modernization and westernization of the Sephardi communities in the Ottoman Empire at the end of the 19th and the beginning of the 20th centuries (Lazar 1999: 851; BenNaeh 2001: 73-96; Stein 2004).

\section{Conclusion}

Ladino readers had many possibilities to become acquainted with Hurwitz's best-selling book Sefer ha-Berit through four different Judeo-Spanish works, published in Salonika and Constantinople throughout the 19th century. On the one

15 A famous Judeo-Spanish newspaper, published in Salonika between 1897 and 1917 (see Gaon 1965: 14; Romero 1992: 184; and Asenjo 2005: 11-12).

16 To understand better these differences, it would be necessary to make a textual comparison between Gategno's translation (1847) and the three versions of the Sefer ha-Berit in Berakah ha-Mešulešet (two from Salonika, 1881 and one from Constantinople, 1900). 
hand, Rabbis 'Amarachi and Śaśon have the merit of bringing up the most fascinating moralistic and scientific issues from Sefer ha-Berit in their famous rabbinic musar books Sefer Darke ha-Adam and Sefer Musar Haśkel, published three times in Salonika (1843, 1849 and 1892). It seems that 'Amarachi also promoted the first translation of Sefer ha-Berit into Ladino, carried out by Rabbi Hayyim Abraham Benveniste Gategno, and published in 'Amarachi's printing press in 1847; literary and personal cooperation and connections between these two Sephardic authors should be studied more thoroughly in future research. On the other hand, the updated translation of Sefer ha-Berit turned out to be very popular in Berakah ha-Mešulešet o Las tres luzes, published three times in the last decades of the 19th century (1881, 1881 and 1900). In these editions, it appeared among other moralistic and entertaining readings, within fashionable European literary genres, in the context of modern, secular Ladino literature. Even if the Ladino translation of Sefer ha-Berit is not complete and does not include the famous chapter on loving one's neighbor, we are lucky to have the Ladino version of this universal moralistic lesson in Sefer Darke ha-Adam, written by 'Amarachi and Śaśon.

\section{References}

'Amarachi, Yiṣhaq Bekor/Śaśon, Yosef ben Meir (1843, 1849 and 1892): Sefer Darke ha-Adam [Book of the Ways of Man]. Salonika. $\rightarrow$ See Śaśon.

Asenjo, Rosa (2005): España y los sefardíes. El desastre del 98 en El Avenir. In: Sefarad 65, 3-40.

Ben-Naeh, Yaron (2001): Hebrew Printing Houses in the Ottoman Empire. In: Nassi, Gad (ed.): Jewish Journalism and Printing Houses in the Ottoman Empire and Modern Turkey. Istanbul, 73-96.

Ben Śaśon, Rafael Yosef (1860): Sefer Zoveah Todah [Offering the Sacrifice of Thanksgiving]. Belgrade.

Ben Veniste, Rafael Yiṣ̣haq (ed.) (1881, 1881): Berakah ha-Mešulešet o Las tres luzes [Triple Blessing or Three Lights]. Salonika.

Benveniste Gategno, Hayyim Abraham (transl.) (1847): Sefer ha-Berit [The Book of Covenant], 2 vols. Salonika.

Borovaya, Olga (2003): The Serialized Novel as Rewriting: The Case of Ladino Belles Lettres. In: Jewish Social Studies 10, 30-68.

Brown, Jeremy (2013): New Heavens and a New Earth: The Jewish Reception of Copernican Thought. Oxford.

Bunis, David M. (2002): Modernization of Judezmo and Hakitia (Judeo-Spanish). In: Spector Simon, Reeva et al. (eds.): The Jews of the Middle East and North Africa in Modern Times. New York, 116-128. 
'Emanuel, Yitshac (1986): Bate defus u-madpisim [Printing Houses and Publishers]. In: Recanati, David A. (ed.): Zikhron Saloniki, vol 2. Tel Aviv, 230-260.

Fontaine, Resianne (2006): The immortality of the soul in Pinhas Hurwitz's Sefer ha-Berit: Philosophers vs Kabbalists. In: Jewish Studies Quarterly 13/3, 223-233.

Fontaine, Resianne (2007a): Natural Science in Sefer ha-Berit: Pinchas Hurwitz on Animals and Meteorological Phenomena. In: Fontaine, Resianne/Schatz, Andrea/Zwiep, Irene E. (eds.): Sepharad in Ashkenaz: Medieval Knowledge and Eighteenth-Century Enlightened Jewish Discourse. Amsterdam, 157-181.

Fontaine, Resianne (2007b): Love of One's Neighbour in Pinhas Hurwitz's Sefer ha-Berit. In: Baasten, Martin F. J./Munk, Reiner (eds.): Studies in Hebrew Language and Jewish Culture, Presented to Albert van der Heide on the Occasion of His Sixty-Fifth Birthday. Dordrecht, 244-268.

Gaon, Moshe David (1965): Haitonut bladino: Bibliografia. Tel Aviv.

Harris, Monford (1982): The Book of Covenant: An Eighteenth-Century Quest for the Holy Spirit. In: Stampfer, Nathaniel (ed.): The Solomon Goldman Lectures. Perspectives in Jewish Learning 3, 39-53.

Hassán, Iacob M. (1971): Problemas de transcripción del judeoespañol. In: Actele celui de-al XII-lea Congres Internațional de Lingvistică şi Filologie Romanică. Bucarest, vol. II, 1235-1263.

Hassán, Iacob M. (1978): Transcripción normalizada de textos judeoespañoles. In: Estudios Sefardíes 1, 147-150.

Hassán, Iacob M. (1988): Sistemas gráficos del español sefardí. In: Ariza, M. et al. (eds.): Actas del I Congreso Internacional de Historia de la Lengua Española. Madrid, vol. I, 127-137.

Hassán, Iacob M. (2008): Sistemas gráficos del español sefardí. In: Romero, Elena et al. (eds.): Sefardíes: Literatura y lengua de una nación dispersa, XV Curso de Cultura Hispanojudía y Sefardí de la Universidad de Castilla-La Mancha. Cuenca, 119-136.

Hurwitz, Pinhas (2014): Sefer ha-Berit ha-shalem. Jerusalem.

Jacobs, Martin (2004): Joseph ha-Kohen, Paolo Giovio, and Sixteenth-Century Historiography. In: Ruderman, David/Veltri, Giuseppe (eds.): Cultural Intermediaries. Jewish Intellectuals in Early Modern Italy. Philadelphia, 67-85.

Lazar, Moshe (ed.) (1999): Sefarad in my Heart: A Ladino Reader. Lancaster.

Lehmann, Matthias B. (2005): Ladino Rabbinic Literature and Ottoman Sephardic Culture. Bloomington.

Levi ben Naḥmias, Eliyahu (ed.) (1900): Berakah ha-Mešulešet o Las tres luzes. Constantinople. 
Muñoz Molina, Natalia (2012): Pasajes del Séfer Šébet Yehudá en la obra judeoespañola Séfer Musar haskel. In: Pomeroy, Hilary/Pountain, Christopher J./Romero, Elena (eds.): Selected Papers from the Fifteenth British Conference on Judeo-Spanish Studies (29-31 July 2008). London, 143-156.

Muñoz Molina, Natalia (2014): Versiones judeoespañolas del Séfer Šébet Yehudá y los paralelos textuales del Darjé haadam. In: Bürki, Yvette/Romero, Elena (eds.): La lengua sefardí. Aspectos lingüisticos, literarios y culturales. Berlin, 125-134.

Riaño López, Ana María (2005): La prosa histórica en lengua sefardí. In: Romero, Elena et al. (eds.): Sefardies: Literatura y lengua de una nación dispersa, XV Curso de Cultura Hispanojudía y Sefardí de la Universidad de Castilla-La Mancha. Cuenca, 397-420.

Robinson, Ira (1989): Kabbala and Science in Sefer Ha-Berit: A Modernization Strategy for Orthodox Jews. In: Modern Judaism 9/3, 275-288.

Romero, Elena (1992): La creación literaria en lengua sefardí. Madrid.

Ruderman, David B. (2002): Some Jewish Responses to Smallpox Prevention in the Late Eighteenth and Early Nineteenth Centuries: A New Perspective on the Modernization of European Jewry. In: Aleph 2, 111-144.

Ruderman, David B. (2012): The Hague Dialogues. In: Berger, Shlomo/Schrijver, Emile/Zweip, Irene (eds.): Mapping Jewish Amsterdam: The Early Modern Perspective Dedicated to Yosef Kaplan on the Occasion of His Retirement, Studia Rosenthaliana 44, 221-239.

Ruderman, David B. (2014): A Best-Selling Hebrew Book of the Modern Era: The Book of the Covenant of Pinhas Hurwitz and Its Remarkable Legacy. Seattle and London.

Śaśon, Yosef ben Meir/'Amarachi, Yiṣhaq Bekor (1843, 1849 and 1892): Sefer Musar Haśkel. Salonika. $\rightarrow$ See 'Amarachi.

Šmid, Katja (2016): Entre la vida y la muerte: dos obras rabínicas sefardíes impresas en Belgrado. In: Pejović, Anđelka et al. (eds.): Estudios hispánicos en la cultura y la ciencia serbia. Kragujevac, 183-197.

Šmid, Katja (2017): El descubrimiento del Nuevo Mundo en dos obras rabínicas sefardíes de Salónica (siglo xix)./Odkritje Novega sveta v dveh rabinskih sefardskih delih iz Soluna (19. stoletje). In: Ars \& Humanitas 11/2, 261-278.

Stein, Sarah Abrevaya (2004): Making Jews Modern: The Yiddish and Ladino Press in the Russian and Ottoman Empires. Bloomington. 


\title{
Magdalena Sitarz and Andrzej Pawelec
}

\section{Yitskhok Katsenelson's Dos lid fun oysgehargetn yidishn folk}

\section{A Story of the Manuscripts and Editions}

\begin{abstract}
Yitskhok Katsenelson יצחק קאֵצענעלסאָן was born on July 1, 1886 in Korelicze and was murdered in Auschwitz on May 1, 1944. He was a poet and playwright creating in Hebrew and Yiddish, as well as a teacher and translator. The world knows him only from one single poetic text, Dos lid fun oysgehargetn yidishn folk [The Song of the Murdered Jewish People], written from October 1943 to January 1944 during the poet's imprisonment in a German internment camp in Vittel. In order to ensure the publication of his work after the war he made several copies of the text. One of the manuscripts was smuggled out to Palestine in a handle of a suitcase. In our paper we offer a preliminary discussion of the history of Katsenelson's manuscripts, since different versions were used for various editions.
\end{abstract}

Keywords: Katsenelson, Yiddish, Shoah, Yiddish Manuscripts

Yitskhok Katsenelson's ${ }^{1}$ Dos lid fun oysgehargetn yidishn folk [The Song of the Murdered Jewish People] is one of the most outstanding literary accounts of the Shoah and is perceived as a work of global importance. It is an epic poem in fifteen cantos written from October 3, 1943 to January 17, 1944 during the poet's imprisonment in a German internment camp for foreign nationals in Vittel, France. Katsenelson did everything in his power to ensure the survival of the elegy. After the work was completed, he produced several copies of the text so that the manuscripts could be buried in the ground or smuggled out of the camp. He also wrote a letter to his relatives in Palestine - political leaders of the Labor movement: Berl Katznelson and Yitzhak Tabenkin - urging them to publish the elegy after the war:

"Only you and my cousin will read this Lament for our people slain in its entirety, with its infants and its babies in the wombs of their mothers. Do not publish this Lament in its fifteen chapters or print it, as long as the curse of man still rages upon earth. If both of you find it proper and necessary that this Lament should be translated into other

1 In our paper we use the YIVO transcription of Yiddish (see: Weinreich 1968, Niborski 1999). In references, Katsenelson's name has various accepted transcriptions. On Katsenelson see among others: Biermann 1994a and 1994b, Cohen 1964, Ek 1964, Ficowski 1982, Katsenelson-Nakhumov 1948, Szeintuch 1984a and 1990. 
languages in order that the nations should know what they too have done to us, since they, too, have been used by and helped this abomination of the nations, the Germans, in the murder of our whole people, not only the Lithuanian and Ukrainian murderers... then keep the translations with you as well until the end of the War. I do not believe that I shall live until that day. Begin the publication of the Lament chapter by chapter in the Jewish press, all on the same day. Only after the fifteen chapters have been disseminated should you publish them as a book. Print the Lament with a dedication to the soul of my Hannah and my brother Berl, who were killed with their families and with my whole people, without any grave. Far more do I fear for you and all my brethren overseas, who are in grave danger" (Katznelson 1958: 27). ${ }^{2}$

This text, known as Katsenelson's 'testament', reached the addressees in July 1944 (see Shapira 1984: 320) but had little impact on the subsequent history of the elegy (see Pawelec/Sitarz 2016). It reveals, however, the author's conviction that his account is of supreme significance for the remaining Jews and humanity at large.

In our paper we present first the historical background - the circumstances in which the poem was created and saved for posterity; subsequently, we discuss the manuscripts and their editions. Since we have had no direct access to various materials, while much still remains unknown or unclear, our account is preliminary.

\section{How Was the Elegy Written and Saved?}

Katsenelson and his eldest son Zvi arrived in Vittel from Warsaw on May 22, 1943 in a group of Polish Jews with papers of South American nationals. The transport was part of a larger German action known as the 'Hotel Polski affair', involving around 2,500 Jews, who bought, or otherwise obtained, foreign documents and were to be exchanged for German nationals interned by the Allies (see Haska 2006). On the day of his arrival Katsenelson started to write a diary. The first phrase, "My son Zvi and I", was written in Yiddish but the author put it in brackets and continued in Hebrew (see Katzenelson 1943). This decision reflects a complex coexistence of both Jewish languages in Katsenelson's life. Before the war, he wrote primarily in Hebrew and was considered as one of the renovators of this sacred language (loshn koydesh) for secular purposes (a Zionist goal). During the war, as an educator and author, he wrote almost exclusively in Yiddish to reach the Jewish population of the Warsaw Ghetto. While in Vittel, he switched to Hebrew in his writings. Presumably, Hebrew was helpful to gain

2 Unless otherwise marked, all translations into English are by AP and MS. 
distance from the oppressive events of the previous year (the German liquidation of the ghetto in which Katsenelson lost his beloved wife, two younger sons, younger brother and his family) which he recreated - against himself - in the diary. This reworking of the trauma seems to have been a necessary step for Katsenelson to fulfil his goal "to bemoan the destruction and annihilation of the whole of our people" (Katznelson 1964: 45), because he had felt powerless with his family murdered ("Alone, I cannot do this!", ibidem). The final entry in the diary reads: "Yes, I want to recount the murder of the four hundred thousand Jews..." (ibidem: 248). Two weeks later Katsenelson started to compose his elegy in Yiddish as a tribute to the 'murdered people'.

We have two main accounts of the 'creative process' offered by women who accompanied Katsenelson in the Vittel camp. Ruth Adler (born 1919 in Dresden) was a young religious Jew who emigrated to Palestine and was arrested while visiting family in Paris. She was interned in Vittel as a British citizen long before Katsenelson's arrival (see Inbar 2014). Miriam Novitch (born 1908 near Grodno) was educated in Polish Vilnius and emigrated to France where she had ties with left-wing, secular circles. During the war she joined the Resistance and in June 1943 was arrested by the Gestapo. Two months later she was transferred to the Vittel camp where she met Katsenelson, not earlier than in the second half of August (see Geva 2015: 76-7).

According to Adler (see Birenbaum 1988), after the quarantine Katsenelson sought contact with other Jews in the camp and was directed to herself and Ben-Zion Chomsky (a Palestinian-born Jew in his late forties, who cooperated with the Jewish military underground in Palestine and had been arrested in the British Embassy in Paris, see Anon. 2012). Katsenelson was so impressed by the young woman's knowledge of the Bible that they started to meet daily. Adler wanted to be closer to the poet: she got the permission from the camp's commandant to move quarters to 'Hotel Providence', where Polish Jews were kept separately from other inmates. In her account, she "was sitting at the poet's side when he was composing the elegy"; every now and again "he stopped to read out a fragment", while she "wiped sweat and tears from his face"; she even "implored him to break off work as the poet looked about to faint, but he continued, even though the pain and effort were killing him" (Birenbaum 1988). In her various accounts Novitch merely states in general that Katsenelson read out his poems to a group of friends (see Novitsh 1963: 16) and to herself (see Novitch n.d.: 8). ${ }^{3}$

3 The typed manuscript is in Polish: "Zakończone poematy, które Kacenelson czytał mi za każdym razem, miały dwa egzemplarze: pierwszy i już poprawiony drugi” [The 
Both versions of events clearly diverge in the subsequent stage, concerning the survival of manuscripts. Adler states that after the poem was completed (Jan. 17, 1944) she and Chomsky buried Katsenelson's elegy and other writings in the ground in several bottles. Soon afterwards (Jan. 26) Adler was informed, however, that she would be sent in a transport to Palestine in exchange for German nationals. It was an opportunity to smuggle the elegy out of the camp. Adler and Chomsky dug out the manuscript, while Katzenelson produced a copy on 15 small pages of very thin paper, one canto per page. Subsequently, the copy was placed in the handle of Adler's suitcase together with the 'testament' and a short poem in Hebrew, ${ }^{4}$ while the bottle with the manuscript was buried in the ground again. On February 28 the Polish Jews were evacuated to a more remote hotel 'Beau-site', in preparation for their imminent transport to the Drancy transit camp (Katsenelson with his son left on April 18) and thence to Auschwitz (April 29). We can assume that Katsenelson had about a month (end of January till end of February) to produce copies of the elegy. Adler left Vittel in June and, as already mentioned, the manuscripts reached Palestine in July 1944.

In the other account, Novitch plays the most prominent role in saving the manuscripts. She convinces Katsenelson to preserve both the fair and draft copies and she buries the bottles in the park with the poet's help. This story repeated countless times in most publications on Katsenelson - has grown almost to mythical proportions (for instance in de Luca 2009: 7 and 14). Novitch also recounts how she persuaded a local woman, Marcelle Pichon (or Rabichon), who did laundry work in the camp, to smuggle out the manuscripts and hide them at her mother's house (see Cohen 1964: 40 and Novitsh 1963: 16). It is perhaps possible to at least partly reconcile both versions if Katsenelson decided at some point in February that he would produce more copies of the elegy and entrusted Novitch with saving the additional batch. This is all the more likely since we have evidence of 6 manuscripts of the elegy. ${ }^{5}$

finished poems, which Katzenelson read out to me each time, had two versions: a draft and a clean copy].

4 I went abased is the poem's English title given by Even-Shoshan (1958: 28).

5 It is also possible that after Katsenelson was transported to Drancy, the elegy was copied by other people. This is suggested by Sofka Zinovieff in the adaptation of her grandmother's diary (Sofka Skipwith born Princess Sophia Dolgorouky), where she states that her grandmother had regarded the elegy as her poetical treasure, which she copied and distributed (see Zinovieff 2009: 185). 


\section{A Story of the Elegy's Editions}

The camp was liberated by Americans on September 12, 1944. Novitch recovered the remaining manuscripts (see Novitsh 1963: 16) and got in touch with Nathan Eck, whose daughter she had been able to save (see Geva 2015: 77 and Zinovieff 2009: 188). Eck himself had also been miraculously saved: on the way to Auschwitz, he jumped out of the train car and managed to reach Paris, where he stayed in hiding to the end of the German occupation. He was true to a promise given to Katsenelson in the Vittel camp: if he survived the war, he would do all he can to publish the elegy (see Ek 1964: 32). Eck typed the manuscript provided by Novitch and found a publishing house in Paris. He was not able, however, to see the manuscript through to publication as in June 1945 he visited New York, invited by the Jewish Writers Association. He took with him both the final proofs of the first cantos and the uncorrected proofs of the rest, as well as Katsenelson's manuscripts saved by Novitch. The printed text was used for a public reading of the whole elegy by well-known Jewish writers. The event was reported in the press and the first two cantos were published in Tsukunft and Yidishe kultur (see Ek 1964: 34). While in New York, Eck received a letter from Paris written by Aaron Tsizling (Israel's future Minister of Agriculture) who asked him not to publish the elegy, as the original, smuggled out by Ruth Adler, was being prepared for publication in Eretz Israel by Katsenelson's relatives. Since Eck believed his promise to Katsenelson had been fulfilled, he gladly agreed to this request. He handed over Katsenelson's manuscripts ${ }^{6}$ and took on other commitments. ${ }^{7}$

As we read in Eck's commemorative essay on Katsenelson, published twenty years after the poet's death in Di goldene keyt, Eck was surprised to learn that his partly uncorrected edition had been printed in 1945, after all. He never found out the reasons; he could only surmise that the sponsors of this edition, the Paris section of Joint, refused to comply with Tsizling's request (see Ek 1964: 34-35).

6 In the Ghetto Fighter's House Archives there is a letter (dated July 16, 1945) from Nathan Eck to Y. Marminsky in New York, in which Eck states that he is handing over the original manuscripts of Yitskhok Katsenelson's works: The Song of the Murdered Jewish People, the drama Hannibal, and some other materials in Hebrew and in Yiddish (cat. no. 22076, Holdings Registry; these manuscripts reached subsequently the Ghetto Fighters' House).

7 While in New York, Eck produced a report on Jewish educational institutions in prewar Poland, part of a larger report on Jewish education in Axis-occupied countries (supervised by Hannah Arendt) for the Commission on European Jewish Cultural Reconstruction (Eck 1946). 
Whatever the reasons, the Paris publication was fortunate since the Eretz Israel edition of the elegy announced by Tsizling (and supervised by Katsenelson's friend from Łódź, Menahem Poznanski) took another two years to materialise (as part of Katsenelson's כתבים אחרונים [Ktavim aharonim, ${ }^{8}$ Last Writings], 19479), probably due to the political circumstances of the time (the Arab-Israeli War of Independence). In the meantime, a partial edition of the elegy appeared in Europe: the first 5 cantos were published in two subsequent issues of the journal אויף דער פריי [Af der frey, Free again] by the inmates of the Displaced Persons Centre in Stuttgart (Katsenelson 1946, 2\&3). This prima facie surprising place of publication is explained by the fact that Ben-Zion Chomsky moved to Stuttgart, where he traced Holocaust survivors for UNRRA in radio broadcasts. We learn from the editorial introduction that the manuscript of the elegy was handed over by Chomsky's wife Rivka (see ibidem: 2.5 ).

In 1948, an edition of the elegy was published in New York by IKUF Farlag (Publishing House of the 'Yidisher Kultur Farband'). It contains two introductions: by Menachem Dorman (the founder of the kibbutz movement publishing house 'Hakibuts Hameuhad') and by Miriam Novitch. There is a parallel edition published the same year in New York (Brooklyn) by Hakibuts Hameuhad. ${ }^{10}$ The IKUF edition was reprinted in 1963. Currently, it is the most widely available version as it was digitized for the 'Spielberg Digital Yiddish Library.'11

The most extensive editorial work was undertaken in 1956 for a new edition of the Last Writings, which included now not only the Vittel pieces but also the Warsaw Ghetto writings retrieved from Dror's Archive and Ringelblum's Archive. The editorial team headed by Shlomo Even-Shoshan examined all five manuscripts of the elegy preserved in GFH and adopted the following rule: "Only one of the versions was used, but where necessary we were ready to put together fragments of other versions and also to borrow a word or so and insert it in the version which we were following" (Even-Shoshan 1958: 31). It is likely that the version followed was the same one which Eck had received from Novitch for the Paris edition.

8 We use the Library of Congress rules for the romanization of the Hebrew alphabet, https://www.loc.gov/catdir/cpso/romanization/hebrew.pdf [access on 26-02-2017].

9 We have not had access to this edition yet. It was published in Tel Aviv by Hakibuts Hameuhad and is listed in the catalogue of the National Library of Israel.

10 We have had no access to this edition which is listed in the catalogue of the Library of Congress. It seems likely that the text is identical with IKUF edition from the same year.

11 The original Yiddish text of the elegy is also available in two other digitized publications: Katsenelson 1964 and 1986 (the latter published together with Ficowski's translation into Polish). 
Since 1956 the Yiddish text of the elegy has appeared many times in other publications, primarily translations (both in Hebrew letters and in transcriptions). As none of these editions involved an extensive (if any) study of the manuscripts, we will stop here. The numerous translations of the elegy merit a separate treatment.

\section{The Manuscripts}

There are five manuscripts of the elegy in GFH Archives catalogued under the number 6631. Their scans are available online. Apart from these five (we will refer to them as manuscript A, B, C, D and E), there was in all likelihood a sixth manuscript which served as the basis for the Stuttgart edition of the first five cantos $^{12}$. The available manuscripts are in variable condition and mostly not easy to read on their own, at least from the scans. In order to decipher difficult fragments one must usually start with the printed editions - only then is it possible to see what is actually written. Consequently, a complete deciphering of the manuscripts would be an arduous task, probably requiring a new set of high-quality scans. We are not sure at this stage whether such an investment would pay off. A variorum edition of the manuscripts would certainly be welcome (see Szeintuch 1984a: X) if one could hope that the differences reflected creative choices of the poet. However, we tend to believe that the available manuscripts are all copies of the finished work, produced by Katsenelson after January 26, 1944 (if Adler's account is correct). They do show various minor discrepancies but most of these can be attributed to errors and mistakes during rewriting.

Manuscripts C \& E stand out from the rest: in both cases each canto fills a single page and they both seem to be written on small-size thin paper. This is certainly the case with manuscript $\mathrm{C}$ which was smuggled out in the handle of the suitcase by Adler. ${ }^{13}$ This copy differs from all others as almost all dates are

12 In the Stuttgart edition there are some words missing in the 5th and 6th stanza of Canto 3. The editor informs us that these fragments are mit tint farflekt [covered with ink], while there are no blots in corresponding places in any of the scans from GFH Archives. It is theoretically possible that the Stuttgart edition was based on the missing first part of Manuscript $\mathrm{E}$ but the rest of the manuscript is too clean to support this conjecture; most probably the Stuttgart manuscript is either missing or in private hands.

13 We would like to thank Anat Bratman-Elhalel, Director of GFH Archive Department, for an opportunity to see this manuscript. She informed us that the fragile pages had been strengthened with special paper. 
partly blotted out with ink. ${ }^{14}$ Manuscript E, which starts with canto 8 , looks at a first glance like an exact copy of manuscript $\mathrm{C}$ with one eye-catching difference: the cantos (except for the last one) are numbered with large, ornamental Hebrew letters. It is hard to imagine that Katsenelson - pressed for time and working in semi-conspiratorial conditions - would indulge in such an exercise. Consequently, one can assume that the letters were calligraphed by someone else. There is, however, a more significant difference between both manuscripts regarding a note added by Katsenelson on December 9, 1943 at the bottom of Canto X (which was finished 3 days earlier, on Dec. 6). The note is a response to a German inspection of the camp the previous day by a special commission from Berlin and the confiscation of all foreign identity papers owned by Polish Jews, which had not been recognized by the South American states (see Cohen 1964: 30 and 36).$^{15}$ The note (which appears also in manuscript D) reads in its fullest version: "Who knows if I will finish these words of lamentation, as all the Jews in Vittel camp, the lean and poor remnant, are drenched in fear of being sent from here back to Poland, I feel sorry for them and for my son." ${ }^{16}$ The version which appears in manuscript $\mathrm{C}$ (as opposed to $\mathrm{D}$ and $\mathrm{E}$ ) is written in Yiddish, and not in Hebrew. The existence of manuscript $\mathrm{E}$ (of which 8 last cantos have been preserved in GFH Archive) raises the question of its possible function. One can speculate that Katsenelson prepared another 'miniature copy' just in case - if another opportunity arose to smuggle the elegy out of the camp.

Manuscript B is, by far, the most legible copy on the whole. ${ }^{17}$ It is complete except for the first double page (the first 13 stanzas of canto 1 are missing). It clearly served as the basis for Eck's Paris edition and its photocopies were attached to the English translation of the elegy by Rosenbloom (Katzenelson 1980). ${ }^{18}$ One can assume that this manuscript was the 'final draft' - the clean copy buried in the ground after the elegy was completed and then dug out for Katsenelson to produce more copies.

14 Katsenelson put exact dates (day, month, year) on all his finished poetic work. In manuscript $\mathrm{C}$ in nearly all cases the year is blotted out, probably to make the identification of the author more difficult in case of the manuscript's detection.

15 Cohen (following Novitch) writes that it was September 8, whereas it must have been December 8,1943 . The erroneous date is repeated in many other publications.

16 Translated from Hebrew by Moshe Shner.

17 The quality of the manuscripts is not consistent: the generally good ones may have hardly legible cantos, due to a change of pen, paper or poor preservation.

18 In most cases it is manuscript $C$ which gets reproduced in various editions, see for instance Biermann's translation from 1994. 
The remaining two manuscripts A \& D have similar, rather poor quality. They are unique as far as the title of canto 1 is concerned, which reads Der troyeriker araynfir [Sorrowful Introduction]. In the other extant copies either the beginning of the elegy is not preserved (manuscript B \& E), or the first canto is not titled (manuscript $\mathrm{C}$ ). However, in Eck's edition (based on the full version of manuscript B) canto 1 is titled "Zing!" [Sing!] and all subsequent printed editions follow his version. This curious fact serves as a suitable introduction to the last section which presents the most striking examples of the editors' impact on the shape of the printed text.

\section{Some Mismatches Between the Manuscripts and Editions of the Elegy}

It seems safe to say that Eck's edition of manuscript B (Katsenelson 1945) has had the most lasting, if mostly unacknowledged, ${ }^{19}$ impact on the subsequent editorial history of the text. It must have served as the main point of reference for the editors of Tel Aviv (Katsenelson 1947) and New York editions (Katsenelson 1948a, 1948b). However, subsequent editors ${ }^{20}$ wanted to improve the first edition which in one case led to a significant distortion.

The preposition in the title of the elegy was changed from 'fun' to 'funm' (Tel Aviv 1947) and 'funem' (New York 1948). There is little evidence in manuscripts B \& C (as well as in the remaining ones) justifying the former reading and absolutely none in the latter case. Katzenelson writes 'fun' consistently, with only a few exceptions when he uses 'funm' (apparently an imitation of spoken language). While 'funem' is a grammatically correct version (preposition plus contracted article 'dem'), it represents here an obvious case of editorial intrusion - the most significant one in the IKUF edition, along with several others of minor importance.

Another case of a glaring mismatch between the manuscripts and the printed text is, on the contrary, a case of editorial indolence: the finishing date of the elegy was changed from January 17 to January 18. The latter date appears in none of the manuscripts. While in manuscript $C$ the digit ' 7 ' in ' 17 ' is covered with a

19 To the best of our knowledge - we have had no access to the Tel Aviv edition.

20 We are commenting here on IKUF's 1963 edition, available online in 'Spielberg Digital Yiddish Library'. We assume that this edition is identical with the first 1948 IKUF edition (because it includes the introductions by Menachem Dorman and Miriam Novitch, both dated 1948) and it is also probable that this New York edition generally follows Hakibuts Hameuhad 1947 edition. 
blot (possibly looking like ' 8 ' to a sufficiently primed viewer), this alone cannot explain the editorial change. It is possible, we speculate ${ }^{21}$, that this error appeared in Eck's partly uncorrected edition, while the editors of New York 1948 edition did not consult manuscript B to correct it.

The correct finishing date is provided only in the Tel Aviv 1956 edition, which sticks to 'funm', however. In all other respects it seems to be the most thoroughly researched and reliable edition. Unfortunately, it has had a very limited influence. Most subsequent publications (primarily translations) rely either on Paris 1945 or New York 1948/1963 editions of the elegy.

\section{Final Comment}

The story of the elegy's manuscripts and editions is full of gaps. So far, our investigations have not provided definitive answers to many factual questions and it is likely that we will never know the facts. We hope, however, that this study - with a parallel study of the elegy's translations (in preparation) - will throw some light on perhaps the most important poetic attempt to pay tribute to the vanished world of Yiddishland.

\section{References}

\section{Primary Sources}

\section{Manuscripts of the Song of the Murdered Jewish People}

http://infocenters.co.il/gfh/search.asp?lang=ENG [access on 25-02-2017].

The pdf file 6631 in GFH Archives holds:

[Scan A]: 17x2 (4 empty) pages, handwritten in Yiddish, Cantos 4 and 7 are missing. Originally catalogued as Holdings Registry file No. 1176 [1.1 6631 (8x2 pages) and 1.26631 (9x2 pages)].

[Scan B]: 26x2 (12 empty) pages, handwritten in Yiddish, missing 13 first stanzas of the Canto 1. Cantos 10,11 and 12 are in the pdf file after Canto 13 and before Canto 14. Originally catalogued as Holdings Registry file No. 1003 [2.1 6631 (8x2 pages), 2.26631 (9x2 pages) and 2.36631 (9x2 pages)].

[Scan C]: 15 pages, handwritten in Yiddish. Originally catalogued as Holdings Registry file No. 1502 [3.1 6631(cover and 7 pages) and 3.26631 (8 pages)].

21 Our scan of the copy of 1945 edition (available in GFH Archives) is incomplete: it ends on canto 14; however, Arno Lustiger's transcription (printed together with Biermann's translation) which is based on this edition has January 18 as the finishing date. 
[Scan D]:16x2 (1 empty) pages, handwritten in Yiddish. Originally catalogued as Holdings Registry file No. 1503 [4.1 6631 (cover and 7 pages) and 4.26631 (9 pages)].

[Scan E]: 8 pages, handwritten in Yiddish, missing Cantos 1-7. Originally catalogued as Holdings Registry file No. 1879 [3.3. 6631 (8 pages)].

[Lost/in private hands]

\section{First Editions of the Song of the Murdered Jewish People}

Katsenelson, Yitskhok (1945): דאיד פון אויסגעהרגעטן יידישן פָאָלק [Dos lid fun oysgehargetn yidishn folk, Song of the Murdered Jewish People]. Pariz [Paris 45].

Katsenelson, Yitskhok (1946): Dos lid fun oysgehargetn yidishn folk [Songs 1-5]. In: אויף דער פריי [Af der frey, Free again] 2, 5-13; 3, 13-14 [Stuttgart 46].

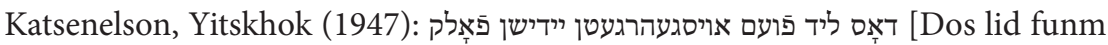
oysgehargetn yidishn folk, Song of the Murdered Jewish People]. In: Idem: בתבים אחרונים [Ktavim aharonim, Last Writings]. Tel-Aviv, 3-49 [Tel-Aviv 47].

Katsenelson, Yitskhok (1948a): דאָָס ליד פונעם אויסגעהרגעטן יידישן פַזָלק [Dos lid funem oysgehargetn yidishn folk, Song of the Murdered Jewish People]. Nyu York [New York 48]. In our paper we refer to the second edition from 1963: Katsenelson, Yitskhok (1963): דאָָס ליד פונעם אויסגעהרגעטן יידישן פַאָלק [Dos lid funem oysgehargetn yidishn folk, Song of the Murdered Jewish People]. Nyu York [New York 63].

Katsenelson, Yitskhok (1948b):ליד פון אויסגעהרגעטן יידישן פָאלק [Lid fun oysgehargetn yidishn folk, Song of the Murdered Jewish People]. Brooklyn [Brooklyn 48].

Katsenelson, Yitskhok (1956): דאָס ליד פונם אויסגעהרגעטן יידישן פَאָלק [Dos lid funm כתבים: oysgehargetn yidishn folk, Song of the Murdered Jewish People]. In: Idem [Ktavim aharonim, Last Writings]. Tel-Aviv, 337-383 [Tel-Aviv 56].

Katsenelson, Yitskhok (1964): דאס ליד פונם אויסגעהרגעטן יידישן פאלק [Dos lid funem

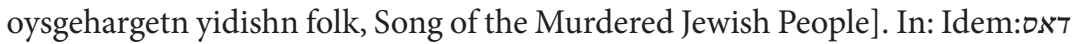
ליד וועגן ראדזינער. דאס ליד פונם אויסגעהרגעטן יידישן פאלק Dos lid vegn Radziner. Dos lid funem oysgehargetn yidishn folk, Song of the Rabbi of Radzyn. Song of the Murdered Jewish People]. Tel-Aviv, 55-101 [Tel-Aviv 64].

Katsenelson, Yitskhok (1986): דאָס ליד פון אויסגעהרגעטן יידישן פָאָלק [Dos lid fun oysgehargetn yidishn folk, Song of the Murdered Jewish People]. Varshe [Warszawa 86].

\section{Secondary Sources}

Anon. (2012): Collection of Documents - Radio Program to Trace Holocaust Survivors - Stuttgart, 1940s, https://www.kedem-auctions.com/content/ 
collection-documents-\%E2 $\% 80 \quad \% 93$-radio-program-trace-holocaustsurvivors-\%E2 \%80 \%93-stuttgart-1940s [access on 26-06-2017].

Biermann, Wolf (1994a): Jizchak Katzenelson, ein Jude [Yitskhok Katsenelson. A Jew]. In: Katzenelson, Jizchak: Dos lied vunem ojsgehargetn jidischn volk. Großer Gesang vom ausgerotteten jüdischen Volk [Song of the Murdered Jewish People. Great Song of the Murdered Jewish People], aus dem Jiddischen übersetzt von Wolf Biermann. Köln, 7-29.

Biermann, Wolf (1994b): Katzenelson, a Mensch [Katsenelson, a Man]. In: Katzenelson, Jizchak: Dos lied vunem ojsgehargetn jidischn volk. Großer Gesang vom ausgerotteten jüdischen Volk [Song of the Murdered Jewish People. Great Song of the Murdered Jewish People], aus dem Jiddischen übersetzt von Wolf Biermann. Köln, 171-195.

Birenbaum, Halina (1988): Poematy zza drutów wyszły na świat? [Poems Came out from Behind the Barbed Wire?]. In: Odgłosy, 43 (22.10.1988), 10.

Cohen, Myer (1964): Biographical Notes. In: Katzenelson, Yitshak: Vittel Diary, translated from the Hebrew by Myer Cohen. Tel-Aviv, 9-40.

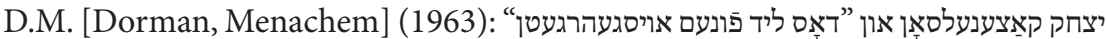
יידישן פَאָלק [Yitskhok Katsenelson un "Dos lid funem oysgehargetn yidishn folk" Yitskhok Katsenelson and the "Song of the Murdered Jewish People"]. In: Katsenelson, Yitskhok: דאָָס ליד פונעם אויסגעהרגעטן יידישן פַאָלק [Dos lid funem oysgehargetn yidishn folk, Song of the Murdered Jewish People]. Nyu York, 7-13 [signed March 25, 1948].

De Luca, Erri (2009): Ai piedi di un albero [At the foot of a tree]. In: Katzenelson, Itzak (2009): Canto del popolo yiddish messo a morte [Song of the Murdered Jewish People], traduzione e cura di Erri De Luca, Milano, 5-19.

Di redaktsye (1964): די צוויי שאַפונגען [Di tsvey shafungen, Two works]. In: Katsenelson, Yitskhok: דאס ליד וועגן ראדזינער. דאס ליד פונם אויסגעהרגעטן יידישן פאלק שומי [Dos lid vegn Radziner. Dos lid funem oysgehargetn yidishn folk, Song of the Rabbi of Radzyn. Song of the Murdered Jewish People]. Tel-Aviv, 5-6.

Eck, Nathan (1946): Poland. In: Jewish Social Studies, 8.3, 71-85.

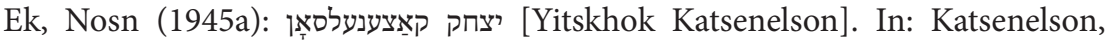
Yitskhok: דאָָס ליד פון אויסגעהרגעטן יידישן פפאלק [Dos lid fun oysgehargetn yidishn folk, Song of the Murdered Jewish People]. Pariz, 7-8.

Ek, Nosn (1945b): פונעם אַרויסגעבער [Funem aroysgeber, From the Editor].

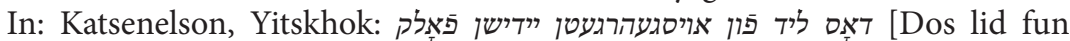
oysgehargetn yidishn folk, Song of the Murdered Jewish People]. Pariz, 7.

Ek, Nosn (1964): מיטן דיכטער אין די יאָרן פון אומקום [Mitn dikhter in di yorn fun umkum, With the Poet in the Years of Destruction]. In: די גאֵלדענע קייט [Di goldene keyt, The Golden Chain] 49, 25-35. 
Even-Shoshan, Shlomo (1958): A New Edition of Yitzhak Katzenelson's Last Works. In: Szner, Zvi (ed.), Extermination and Resistance. Historical Records and Source Material. Tel-Aviv, 28-31.

Ficowski, Jerzy (1982): Słowo o Icchaku Kacenelsonie [About Yitskhok Katsenelson]. In: Kacenelson, Icchak: Pieśń o zamordowanym żydowskim narodzie, przekład, wstęp i przypisy Jerzy Ficowski. Warszawa, 6-11.

Folman Raban, Havka (2001): My Teacher, Yitzhak Katzenelson. In: Eadem: They are still with me. Translated from Hebrew by Judy Grossman, Tel-Aviv, 174-179.

Geva, Sharon (2015): 'To collect the tears of the Jewish people': the story of Miriam Novitch. In: Holocaust Studies 21:1-2, 73-92. DOI: 10.1080/17504902.2015.1062276.

Haska, Agnieszka (2006): "Jestem Żydem, chce wejść": Hotel Polski w Warszawie, 1943 ["I’m a Jew, I want to come in": Hotel Polski in Warsaw, 1943]. Warszawa.

Inbar, Lior (2014): Ruth Adler: Bearer of Yitzhak Katzenelson's Last Poem, http:// www.gfh.org.il/eng/?CategoryID=349\&ArticleID=621\&SearchParam=Ruth +Adler [access on 26-06-2017].

Kacenelson, Icchak (1982): Pieśń o zamordowanym żydowskim narodzie [Song of the Murdered Jewish People], przekład, wstęp i przypisy Jerzy Ficowski. Warszawa. The bilingual edition: Kacenelson, Icchak (1986): Pieśn o zamordowanym żydowskim narodzie [Song of the Murdered Jewish People], przekład, wstęp i przypisy Jerzy Ficowski. Warszawa.

Katzenelson, Itzhak (1943): Pinkas Vitel [manuscript in Ghetto Fighter's House Archives, cat. no. 6630 (Collections Section), http://infocenters.co.il/gfh/ search.asp?lang=ENG], [access on 25-06-2017].

Katzenelson, Jizchak (1994): Dos lied vunem ojsgehargetn jidischn volk. Großer Gesang vom ausgerotteten jüdischen Volk [Song of the Murdered Jewish People. Great Song of the Murdered Jewish People], aus dem Jiddischen übersetzt von Wolf Biermann. Köln.

Katznelson, Yitskhak (1958): Letter to Berl Katznelson and Yitzhak Tabenkin, translated by T.M. Lask. In: Szner, Zvi (ed.), Extermination and Resistance. Historical Records and Source Material. Tel-Aviv, 27.

Katznelson, Yitshak (1964): Vittel Diary, translated from the Hebrew by Myer Cohen. Tel-Aviv.

Katzenelson, Yitshak (1980): The Song of the Murdered Jewish People, translated and annotated by Noah H. Rosenbloom. Tel-Aviv.

Katsenelson, Yitskhok (1984): יידישע געטא־־כבים [Yidishe geto-ksovim, Yiddish Ghetto Writings], edited by Yechiel Szeintuch. Tel-Aviv. 
Katsenelson-Nakhumov, Tsipoyre (1948):יצחק קאצצענעלסאָן [Yitskhok Katsenelson]. Buenos-Ayres.

[Library of Congress Romanization Table for Hebrew and Yiddish], https:// www.loc.gov/catdir/cpso/romanization/hebrew.pdf [access on 26-02-2017].

Lubetkin, Zivia (1981): With Yitzkhak Katzenelson. In: Eadem: In the Days of Destruction and Revolt. Tel-Aviv, 62-67.

Lustiger, Arno (1994): Anmerkungen zu Katzenelsons Werk und zur phonetischen Transkription [Notes on Katsenelson's Work and on the Phonetic Transcription]. In: Katzenelson, Jizchak: Dos lied vunem ojsgehargetn jidischn volk. Großer Gesang vom ausgerotteten jüdischen Volk [Song of the Murdered Jewish People. Great Song of the Murdered Jewish People], aus dem Jiddischen übersetzt von Wolf Biermann. Köln, 229-232.

Niborski, Yitskhok (1999): ווערטערבוך פון לשון־קדוש-שטאמיקע ווערטער אין יישישיש [Verterbukh fun loshn-koydesh-shtamike verter in yidish, Dictionary of The Yiddish Words of Hebrew Origin]. Pariz.

Novitch, Miriam (n.d.): Icchak Kacenelson [Manuscript in Polish, GFH Archives, cat. no. 6274 (Holdings Registry), http://infocenters.co.il/gfh/list.asp, acces on 25-08-2015].

Novitsh, Miriam (1945): אריינפיר־ווארט [Araynfir-vort, Introduction], fun frantsoyzish iberzetst durkh Nosn Ek. In: Katsenelson, Yitskhok: איאָס ליד פון אויסגעהרגעטן יידישן פַאָלק Murdered Jewish People]. Pariz, 9.

Novitsh, Miriam (1963): ווי יצחק קאַצענעלסאָן האָט געשריבן זיינע קלאָג־־לידער [Vi Yitskhok Katsenelson hot geshribn zayne klog-lider, How Yitskhok Katsenelson wrote his Lamentations]. In: Katsenelson, Yitskhok: פאָָס ליד פונעם אויסגעהרגעטן יידישן [Dos lid funem oysgehargetn yidishn folk, Song of the Murdered Jewish People]. Nyu York, 15-16 [signed April 1, 1948].

Pawelec, Andrzej/Sitarz, Magdalena (2014): Ostatni Żyd w Europie [The Last Jew in Europe]. In: Zeszyty Naukowe Centrum Badań im. Edyty Stein 12, 203-220.

Pawelec, Andrzej/Sitarz, Magdalena (2016): "Dos lid funem ojsgehargetn jidiszn folk" Jicchoka Kacenelsona - po polsku [Yitskhok Katsenelson's "Dos lid funem oysgehargetn yidishn folk" Jicchoka Kacenelsona - in Polish]. In: Przekładaniec 32, 80-92.

Shapira, Anita (1984): Berl: The Biography of a Socialist Zionist: Berl Katznelson 1887-1944. Cambridge.

Sitarz, Magdalena/Pawelec, Andrzej (2015): 'Fartaytsht un farbesert': Wolf Biermann and Yitskhok Katsenelson's 'Dos lid funem oysgehargetn yidishn folk'. In: Studia Litteraria Universitatis Iagellonicae Cracoviensis 10.1, 37-44. 
Szeintuch, Yechiel (1984a): The Warsaw writings of Yitzhak Katzenelson (19401943). In: Katsenelson, Yitskhok: יידישע געטאָּכתבים [Yidishe geto-ksovim, Yiddish Ghetto Writings], edited by Yechiel Szeintuch. Tel-Aviv, III-X.

Szeintuch, Yechiel (1984b): הקדמה [Hagdome, Introduction]. In: Katsenelson, Yitskhok: יידישע געטאָ-פתבים." [Yidishe geto-ksovim, Yiddish Ghetto Writings], edited by Yechiel Szeintuch. Tel-Aviv, 5-7.

Szeintuch, Yechiel (1990): יצחק קצנלסון - כתבים שניצלו מגיטו וארשה וממחנה ויטל [Yitshhak Katsenelson: ketavim she-nitslu mi-geto Varshah umi-mahane Vitel, Yitzhak Katzenelson's Rescued Manuscripts. From The Warsaw Ghetto And The Vittel Concentration Camp]. Yerushalayim.

Weinreich, Uriel (1968): Modern English-Yiddish Yiddish-English Dictionary. New York.

Zinovieff, Sofka (2009): Tajemnice Carskiego Dworu. Zapiski Czerwonej Księżniczki [originally published in English in London, 2007 as: Red Princess. A Revolutionary Life], transl. by Sławomira Kaczmarek. Warszawa. 



\title{
Sandra Birzer
}

\section{The Yiddish Subjective Resultative Construction Based on the Adverbial Participle: Convergences and Divergences with Co-Territorial Languages}

\begin{abstract}
This paper discusses an understudied construction in Yiddish, Polish and Russian, namely the subjective resultative construction based on the adverbial participle (AP). The semantic verb classes with subjective resultative meaning denote movements of the body or body parts, the arrangement of clothing and other objects close to the body, mental states and the human condition in general. In contrast to Russian, Yiddish and Polish both allow variation in conveying the subjective resultativity of mutative verbs: both the participle I and II or both imperfective and perfective adverbial participle respectively can be used. The major divergence between Yiddish and its co-territorial languages is the existence of a construction employed exclusively with intransitive mental verbs and specified for subjective resultativity, active voice and direct evidentiality in the latter languages.
\end{abstract}

Keywords: Subjective Resultative, Adverbial Participle, Yiddish, Polish, Russian

\section{Introduction}

Yiddish is usually considered a Germanic language, whereas (most of) its historic co-territorial languages are Slavonic ones. The aim of this paper is to explore the con- and divergences of the Yiddish subjective resultative construction based on the adverbial participle (henceforth AP) with its co-territorial languages Russian and Polish.

The subjective resultative is a diathesis in which "the underlying subject of the state (which is expressed by the surface subject of the stative predicate) is coreferential with the underlying subject of the preceding action [resulting in the state described by the stative predicate - S. B.]" (Nedjalkov \& Jaxontov 1988: 9, see example (1-2)).

(1) YID ongeboygn iber ir, iz geshtanen an alte bend-AP.PST over her be-AUX.3SG stand-PTCP.PST an old-Nom froy ... woman-NOM 'Bending over her, stood an old woman...' (Forverts 2007.03.23) 
(2) YID gezesn $\begin{aligned} & \text { un geshlofn } \\ & \text { sit-PTCP.PST and sleep-PTCP.PST }\end{aligned}$ be-AUX.3SG one on floor
oystsiendik di fis.
stretch-AP.PRs the feet-ACC
'They sat and slept on the floor, stretching out their feet.' (Forverts
2007.03.16)

For Yiddish, they are an interesting research object for several reasons: Firstly, no research has been conducted on Yiddish resultative constructions so far.

Secondly, from a typological perspective, passive past participles are considered to be one of the most widespread means for expressing resultativity. This applies also for German (cf. Litvinov \& Nedjalkov 1988) as well as the North Slavonic languages (cf. Wiemer \& Giger 2005). Yet German and North Slavonic differ fundamentally with respect to the productivity of the passive past participle formative: in German, the passive past participle can be formed of any verb (as it is needed to form, among others, the perfect tense; a discussion of the term passive past participle will follow below) whereas in North Slavonic it is semantically restricted mainly to transitive verbs. Thus, German draws exclusively on the passive past participle for expressing subjective resultativity, whereas Russian and Polish resort to two strategies - the adverbial participle (cf. Birzer 2010: 85-107 for an account of Russian) and the passive past participle (cf. Wiemer \& Giger 2005: 13-14 for Russian and 2005: 69 for Polish). Just like German, Yiddish has no semantic restrictions on forming the passive past participle, but as we will see, it nonetheless employs both the past participle (1) and the adverbial participle (2) for expressing subjective resultativity.

Thirdly, the subjective resultative construction based on the adverbial participle conjoins two phenomena which are per se considered peripheral, but play a pivotal role for each other: the subjective resultative per se is claimed to be undeveloped in many languages of the world, among them Russian (cf. Nedjalkov \& Jaxontov 1988: 9), i.e. one of the co-territorial languages of Yiddish. The adverbial participle, on the other hand, is often ascribed peripheral morphosyntactic significance, as it is considered to be an infrequent inflectional form (cf. Feret 2005: 37 for Polish; Švedova et al. 1980: $\$ 1591$ for Russian) used mainly in the formal register.

On the basis of corpus data, we will explore which morphosyntactic and semantic contexts trigger the usage of the two Yiddish subjective resultative constructions, and which con- and divergences with Russian and Polish can be found therein.

The paper is organized as follows. Following the Introduction, the second section will give a survey on the state of the research on the adverbial participle, including the terminological question attached to it, and on subjective resultative constructions. The third section describes methodological issues of 
retrieving the corpus data that will be analyzed in section 4 . The concluding section 5. then discusses the con- and divergences of the Yiddish subjective resultative constructions with Russian and Polish.

\section{State of the Art}

As resultative constructions describe the state resulting from a preceding action, we will at first give a survey of the formants and the taxis meanings of adverbial participles in our object languages. In the second subdivision of this section the current state of research on (subjective) resultative constructions in our object languages and German will be discussed. In both subsections we will set out with the co-territorial languages and German in order to make the specificities of Yiddish clearly discernible against this background.

\subsection{Adverbial Participles and Their Taxis Meanings}

As adverbial participle ${ }^{1}$ we define non-finite inflectional verb forms with adjunct status that serve as secondary predication, modify their matrix verb, are in a taxis relation to the matrix verb and are co-referential with an argument of the matrix verb (see also Haspelmath 1995: 3-8 for defining criteria).

The two Slavonic object languages, Polish and Russian, form only active adverbial participles. As a rule (with some rare exceptions), the aspect of the given verb determines which formant is used: the suffixes $-a c$ and $-a(j a)$ respectively are employed for the imperfective adverbial participle marking simultaneity (3-4), whereas the perfective adverbial participle is formed with the suffixes -wszy and $-v(\check{s} i)$ respectively and denotes anteriority $(5-6){ }^{2}$

1 In different linguistic traditions, this kind of verb forms is denoted by different terms, some of which denote different linguistic concepts in various traditions. For example, in linguistic typology converb is used to denote the item under investigation in this paper, whereas in Yiddish linguistics, converb denotes detachable verbal prefixes (for more terminological ambiguities concerning our item under investigation see Haspelmath 1995: 2-3). To avoid such ambiguities, we opted for the term adverbial participle, which reflects the functional and morphological status of the item.

2 In order to secure a consistent glossing of the adverbial participle, we decided to distinguish between adverbial participles denoting simultaneity (SIM) and anteriority (ANT), as the grammatical categories that determine the taxis distinction vary across our object languages. Please note that the default taxis meaning conveyed in the glossing and the actual reading in certain contexts do not necessarily coincide; this divergence will commented upon in the corresponding places. If not indicated otherwise, 
(3) POL Obudziłem_się, leżąc na czymś twardym. wake_up-PST.1SG.M lie-AP.sIm on something hard.

'I woke up, lying on something hard.' (E. Białołęcka. 2004. Tkacz iluzji.)

(4) RUS Stjuardessa, leža v šezlonge, čitala "Mumu". stewardess-NOM recline-AP.SIM in chaiselongue read-PST.3SG.F Mumu-ACC 'The stewardess, reclining in a chaiselongue, read "Mumu"'

(S. Dovlatov. 1984. Inaja žizn’)

(5) POL Anna wstawszy od fortepianu podeszła do okna. Anna-NOM stand_up-AP.ANT from piano go-PST.3SG.F to the window 'Having stood up from the piano, Anna went to the window.' (W. Szymański. 2001. Niedźwiedź w katedrze)

(6) RUS Napisav zajavlenie, Maksimus položil write-AP.ANT petition-ACC Maksimus-NOM put-PST.3sg.m ego na stol...

it-ACC onto the table

'Having written the petition, Maximus put it onto the table.' (G. Sadulaev. 2008. Tabletka.)

In both Russian and Polish the normative rule for the co-reference of the adverbial participle is that the covert subject of the adverbial participle be co-referent with the first argument of the matrix sentence, although instances of co-reference with other matrix verb arguments can be observed if the semantic context provides for the corresponding reference tracking (cf. Feret 2005: 84 for Polish and Yokoyama 1984 and Rappaport 1984 for Russian).

Feret states for Polish that the type number of adverbial participles in -wszy is decreasing; they are being replaced by adverbial participles in - ac (cf. Feret 2005: 37). Therefore, one aim of our corpus analysis will be to check whether this tendency also affects the subjective resultative construction: as it marks the state resulting from a preceding action, one would expect this action to be encoded by a perfective adverbial participle and thus $-w s z y$. For Russian no similar tendency has been attested.

German also features two adverbial participles. In Zifonun et al. (1997: 2214$2230)$ they are called participial constructions ("Partizipialkonstruktionen") and defined as

"unflektierte Partizipien I oder II, die um mindestens ein Komplement oder Supplement erweitert sind und die als Teil einer KM [kommunikativen Minimaleinheit - S.B.] verwendet werden, jedoch nicht als $\mathrm{K}_{\mathrm{PRD}}$ " [Prädikativkomplement].

all examples in this paper are taken from the Corpus of Modern Yiddish, the Polish National Corpus and the Russian National Corpus. 
[uninflected participles I or II, which are accompanied by at least one complement or adjunct and are used as part of an utterance, but not as complement of the primary predication - S. B.] (Zifonun et al. 1997: 2214)

In the adverbial construction the participle I denotes (partial) simultaneity (7; cf. Zifonun et al. 2219).

$\begin{array}{lllll}\text { (7) GER Das Kind lief } & \text { lachend } & \text { davon. } \\ \text { the child-NOM run-PST.3SG } & \text { laugh-AP.SIM } & \text { away } \\ \text { 'Laughing, the child ran away.' } & & \end{array}$

The participle II or past participle is polyfunctional. Before turning to its function in the adverbial participle construction, let us consider its main functions, namely that of constitutive element of the (analytical) perfect tense and the passive. The perfect tense is formed with the help of the auxiliaries sein 'be' or haben 'have' and the participle II. Transitivity is the general criterion for the distribution of the two auxiliaries: transitive verbs usually take haben 'have' and intransitive verbs sein 'be'. Yet it has to be pointed out that for several intransitive verbs denoting the position of animate bodies, such as stehen 'stand', sitzen 'sit' etc. the auxiliary assignment is subject to regional variance: in the Northern varieties of German the auxiliary haben 'have' is preferred, and sein 'be' in the Southern varieties (Zifonun et al. 1997: 1874). Note that these stative verbs may be considered the lexicalized expressions of agentive subjective resultatives which are anteceded by an agentive and terminative action (cf. Nedjalkov \& Jaxontov 1988:7), e.g. aufstehen 'stand up' $\rightarrow$ stehen 'stand' or sich (hin)setzen 'sit down' $\rightarrow$ sitzen 'sit'. German grammaticography traditionally distinguishes the so-called Vorgangspassiv (dynamic passive; 8), formed with the auxiliary werden 'become' and the participle II, and the Zustandspassiv (stative passive; 9), formed with the auxiliary sein 'be' and the participle II. It is assumed that the stative passive can be formed only of verbs that also allow the dynamic passive, whereas

"als allgemeine sein-Konverse [...] diejenigen Konstruktionen [gefasst werden], die zwar zu entsprechenden Aktiv-Konstruktionen konvers sind, zu denen jedoch kein entsprechendes werden-Passiv existiert." (ex. 10; Zifonun et al. 1997: 1817)

[as general sein 'be'-conversion are defined all those constructions, which constitute a conversion of the corresponding active constructions, but for which no corresponding dynamic passive exists.]
(8) GER
Das Haus
wurde
1923 fertiggestellt.
the house-Nom become-PST.3SG
erect-PTCPII
'The house was erected in 1923'. 

(9) GER Das Haus ist fertiggestellt.
the house-NOM be-PRS.3SG erect-PTCPII
(10) GER Seine Stirn war gerunzelt
his brow-NOM be-PST.3SG crinkle-PTCPII
'He frowned (lit. his brow was crinkled).' (cited after Zifonun et al. 1997: 1818)

Note that for the German resultative also "[d]ie wichtigste Konstruktion ist sein + Partizip II [...], auf die alle anderen zurückgeführt werden können." (Nedjalkov \& Jaxontov 1988: 2). ${ }^{3}$

Let us keep this observation in mind if we now turn to the adverbial participle construction based on the participle II: it always marks anteriority of the denoted action (11-16; cf. also Zifonun et al. 2219), but since it does not require an auxiliary, it abstracts from the deictic category of tense (cf. especially (11), where the adverbial participle is formed from a non-terminative and non-transformative transitive verb that implies no resulting state; anteriority of the denoted action is prominent here), from the dichotomy of active vs. passive (cf. 12 vs. 14) and the distinction of stative passive vs. sein-conversion (cf. 12 vs. 13).
(11) GER Die Zeitung gelesen, ging er in die Arbeit. the newspaper-ACC read-AP.ANT go-PST.3SG he to the work 'Having read the newspaper, he went to work.'
(12) GER Vor langer Zeit fertiggestellt, steht das Haus before long time complete-AP.ANT stand-PRs.3SG the house-NOM noch_immer.
still
'Erected a long time ago, the house is still standing.'
(13) GER Die Stirn gerunzelt, betrachtete er das Bild. the brow-ACC crinkle-AP.ANT gaze-PST.3sg he the picture-ACC 'Frowning, he gazed at the picture.'
(14) GER Vom Sofa aufgestanden reichte sie dem Besucher. from sofa-DAT get_up-AP.ANT shake-PST.3SG she the visitor-DAT die Hand. the hand-ACC 'Having gotten up from the sofa, she shook hands with the visitor.'

German also witnessed normative tendencies to prescribe that the covert subject of the adverbial participle be co-referent with the first argument of the matrix sentence (cf. Bungarten 1976: 58 ff. mentioned in Zifonun et al. 1997: 2216), but

3 [the most important construction is sein , be ${ }^{\mathrm{c}}+$ participle II, to which all other [constructions] can be traced back - S.B.]. 
more recent grammaticographic works describe the adverbial participle to be co-referent predominantly with the first argument of the matrix sentences, but also with other arguments (cf. Zifonun et al. 1997: 2219). The German adverbial participle is considered to be a phenomenon of formal registers (cf. Zifonun et al. 1997: 2229-2230) ${ }^{4}$ and thus differs from the usage of the Yiddish adverbial participle.

The Yiddish participles have the same functional domains as the German ones. When used in the adverbial participle construction, the Yiddish participle I (called gerundive in Yiddish grammaticography) denotes simultaneity (15). In comparison to some other Germanic languages, Yiddish has reduced the number of tenses. The auxiliary hobn 'have' or zayn 'be' and the uninflected participle II (called partitsip) form the past tense. As Mark (1978: 277) notes, the number of verbs forming the past tense with the help of zayn 'be' is decreasing; hobn 'have' is used instead. Mark (1978: 277-279) explicitly mentions twelve verbs that form the past tense with zayn 'be', among them the stative verb blaybn 'remain', the verbs zitsn 'sit', lign 'lie', shteyn 'stand', which all denote positions of (animate) bodies, and the transformative verb shtarbn 'die.' If one considers that Yiddish distinguishes between the "true" passive with vern 'become' + participle II from the so-called apparent passive with zayn 'be' + participle II (16; cf. Hall 1967: 30) that marks the resultative, it seems that Yiddish is developing towards a crystallization of functions via the specialization of the auxiliaries hobn 'have' (past tense), vern 'become' (passive) and zayn 'be' (resultative). ${ }^{5}$ When the participle II is used in the adverbial participle construction, it marks anteriority (17; cf. Mark 1978: 343). As in German, the adverbial participle construction is abstracted from tense and diatheses due to the absence of the corresponding auxiliaries. $^{6}$

4 It would be worth testing how native speakers of German judge the acceptability of sentences containing adverbial participles. From my own intuition as a native speaker I would expect subject resultative constructions denoting the position of body parts of type (13) to get the highest acceptability score, and the mere marking of anteriority, as in (11), to get the lowest score. This might be an indicator that the adverbial participle construction with the participle II develops towards a marker of subjective resultativity.

5 Since the subjective resultative construction based on the adverbial participle does not employ an auxiliary, this hypothesis cannot be tested in this paper.

6 In this context, it should also be mentioned that an ellipsis of the auxiliary is possible in Yiddish (cf. Mark 1978: 342-343). Mark's examples feature several participles detached by commas to be followed by a finite verb form, but it remains unclear whether this is typical for the elliptical construction and thus excludes the interpretation as an agglomeration of adverbial participles. 
(15)

YID ... lakhndik hot $\quad$ dos yungvarg
laugh-AP.SIM have-AUX.3SG the young_people-NOM in_pairs
zikh tseshotn ibern vald ...
REFL disperse-PTCPII across woods
'Laughing, the young people in pairs dispersed over the woods.'

(Y. Opatoshu. In poylishe velder)

(16)

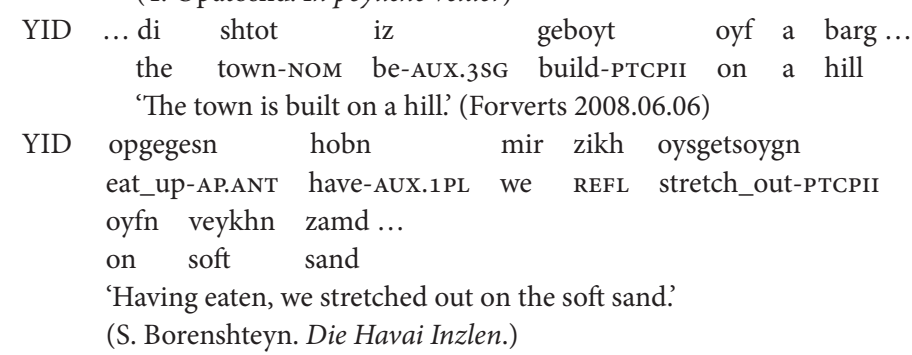

In Yiddish, semantic traceability (cf. Mark 1978: 337) and the syntactic position, i.e. linear closeness to the referent in question (cf. Mark 1978: 337-338), determines the co-reference of the adverbial participle. In this respect Yiddish is much less normative than the other languages.

\subsection{Research on Subjective Resultatives}

As a type of diathesis, the resultative has received attention from many sides, among them language typologists. The Leningrad/St. Petersburg School of Linguistic Typology dedicated one volume edited by Nedjalkov (original publication in Russian 1983; cited in this paper in the English translation from 1988) to the resultative, which laid the ground for the exploration of resultative constructions in various individual languages, among them the languages coterritorial to Yiddish (most notably Wiemer \& Giger 2005 on the North Slavonic and Baltic languages) and German (Litvinov \& Nedjalkov 1988). To the best of our knowledge, there have been no publications in this vein on Yiddish.

As the aim of this paper is to describe the specificities of the subjective resultative construction based on the adverbial participle, this section will give a short general survey on the different types of resultatives and resultative constructions and will then relate the state of research for our languages of interest, with a special focus on subjective resultative constructions. On this basis our research questions will be formulated.

In their definition of resultative, Nedjalkov and Jaxontov make the following distinction between resultative and stative:

"The term resultative is applied to those verb forms that express a state implying a previous event. The difference between the stative and the resultative is as follows: the 
stative expresses a state of a thing without any implication of its origin, while the resultative expresses both a state and the preceding action it has resulted from." (Nedjalkov \& Jaxontov 1988: 6)

Thus there exist "pairs" of verbs, one of which denotes an action resulting in a certain state, such as YID zikh zetsn 'sit down', and the other one expressing the state, such as YID zitsn 'sit'.

The resultative as such is then subcategorized in object resultative and subject resultative:

"In the case of the subjective resultative, the underlying subject of the state [...] is co-referential with the underlying subject of the preceding action, while in the case of the objective resultative it is co-referential with the underlying object of the latter." (Nedjalkov \& Jaxontov 1988: 9)

As we have seen in the preceding subsection, co-referentiality is also an issue with adverbial participles. Therefore we will shortly discuss the implications coreferentiality has on the verb semantics and thus on the semantic roles of the arguments, since this may give some hints as to the lexical domains that allow for the subjective resultative construction based on the adverbial participle.

The subjective resultative is usually derived from intransitive verbs and the objective resultative from transitive ones. Since, speaking in the terms of semantic roles, the objective resultative focuses on the state of the patient, it is not too surprising that in many languages the prototypical resultative construction displays some structural parallels to the passive diathesis (compare e.g. the polyfunctionality of the German participle II above; cf. also Nedjalkov \& Jaxontov 1988: 17-22). Therefore, potential candidates for the objective resultative are transitive telic verbs denoting transformations. Due to the fact that with the subjective resultative the underlying subject of the state is co-referent with the subject of the preceding action, an animate subject has to be assumed; the most probable semantic roles for it are thus agent and experiencer.

However, there also exists a subvariety of the subjective resultative derived from transitive verbs:

"A resultative form may be derived from a transitive verb and have subjective diathesis if the underlying object of the previous action refers to a body part or possession of the underlying subject or to something in immediate contact with the latter. In these cases the result of the action affects the underlying subject rather than the immediate patient of the action." (Nedjalkov \& Jaxontov 1988: 9)

The affectedness of body parts or possessions of the subject makes an agentive subject most probable, yet the possible range of objects in immediate contact 
with the subject make predictions on the semantic domains of corresponding verbs very difficult. This once again underlines the necessity of a corpus study.

The term possessive resultative, which Nedjalkov and Jaxontov use to denote the kind of resultative mentioned last, takes us right into the discussion of the research on individual languages, because in their linguistic traditions the term is usually associated with just one specific phenomenon that falls under the definition of Nedjalkov and Jaxontov, but does not mirror the whole picture.

Wiemer and Giger (2005) provide a description of the resultative constructions in the Northern Slavonic and Baltic languages from a geolinguistic and contact linguistic perspective (cf. Wiemer \& Giger 2005: i). They claim their research to be data-oriented (this and the following see Wiemer \& Giger 2005: i), as they use "alle aus der Sekundärliteratur sowie der eigenen Forschung verfügbaren Daten"'. One has to be aware that this choice of data may suffer from imbalances (as Wiemer and Giger (2005: i) mention themselves), since individual papers reflect the research interests of their authors. Again, this underlines the necessity of a corpus-based study.

For Standard Russian Wiemer and Giger (2005: 13) claim that both subjective and objective resultatives can be formed only with the help of the perfective participle passive (cf. also the examples given by Knjazev 1988: 344-345); the broad majority of the subjective resultatives may be considered bidiathetical, as they can be traced back both to an transitive (19) and an intransitive verb (20) with the same stem that is formed with the help of the reflexive marker -sja (18; cf. Wiemer \& Giger 2005: 13).

(18) RUS On vzvolnovan. (cited after Wiemer \& Giger 2005: 13)

he-NOM worry-PTCP.PERF.PASS.M.SG

'He is worried.'

(19) RUS Plochie novosti vzvolnovali ego.

bad-NOM.PL news-NOM worry-PST.PERF.PL him

'The bad news worried him.'

(20) RUS On vzvolnovalsja.

he-NOM worry-PST.PERF.SG.M

'He worried.'

The usage of the adverbial participle for the expression of the subjective resultative is mentioned only for the Russian substandard and for the North(West) Russian dialects. In the substandard the subjective resultative based on the adverbial participle is considered to be unproductive (cf. Wiemer \& Giger

7 [all data from the secondary literature and from own research work. - S. B.]. 
2005: 27), whereas in the North(West) dialects it is used productively to mark both subjective and objective resultatives (cf. Wiemer and Giger 2005: 29-35 and Trubinskij 1988: 392-395). Trubinskij (1988: 394) discusses two examples for the possessive resultative (21), yet their missing contextual embedding makes it difficult to judge as to whether the speaker indeed intended to express resultativity. (21) implies the state 'he is in possession of the money', which is relevant if the person eventually buys something with the money or gets robbed, i.e. if the succeeding event recurs on the result, but not if the person afterwards switches on the TV or answers the phone. Trubinskij claims that "this structure is found, [sic!] only occasionally, mostly in the dialects spoken outside the area where the subjective resultative is regularly used." (1988: 394). Quite interestingly, neither Wiemer and Giger nor Knjazev or Trubinskij discuss examples of the kind (22-23), although they contain a transitive verb denoting an action whose result without doubt affects the underlying subject more than the patient object. Birzer (2010: 103) classifies the analyzed verbs as subjective-resultative ones, which can be divided into two semantic subgroups: the first subgroup denotes movements of body parts and the second one the arrangement of clothing. One aim of this paper will be to explore whether such subjectiveresultative verbs also occur in Polish and Yiddish, and whether the subgroups to be established for each language coincide or not.

(21) RUS On den'gi polučivši (cited after Trubinskij 1988: 394)

he-NOM money-ACC receive-AP.PERF

'He has received the money.'

(22) RUS - Nu, da, - opustiv golovu, priznalsja on. Well yes droop-AP.ANT head-ACC admit-PST.3SG.M he-NOM '"Well, yes," he admitted, drooping his head.'

(I. Grekova, V vagone. cited after Birzer 2010: 103)

(23) RUS Potom ja ... stal chodit', sgorbivšis' i then I-NOM start-PST.1sg.m walk-INF hump_back-AP.ANT and opirajas' na ... palku.

prop-AP.Sim on walking_stick-ACC

'Then I started to move, humping my back and propping myself on a walking stick.'

(V. Kaverin. Pesočnye časy. cited after Birzer 2010: 103)

(24)

\begin{tabular}{|c|c|}
\hline RUS & $\begin{array}{l}\text { Lžesvidetel' stojal } \quad \text { odin } \\
\text { false_witness-NOM stand-PST.3SG.M alone-NOM.SG.M on pavement-LOC } \\
\text { zapachnuv rubašku .... } \\
\text { make_overlap-AP.ANT shirt-ACC } \\
\text { 'The false witness stood alone on the street, keeping the ends of his shirt } \\
\text { overlapping.' } \\
\text { (V. Tokareva, Odin kubik nadeždy. cited after Birzer 2010: 103) }\end{array}$ \\
\hline
\end{tabular}


The information on the subjective resultative constructions given in Wiemer and Gieger (2005) is somewhat contradictive: in the section dedicated to Polish they state that subjective resultatives formed with the help of the passive participle ${ }^{8}$ are highly frequent (and give examples only of this construction type, cf. Wiemer \& Giger 2005: 69), but in the synoptical table of resultative constructions at the end of the book it is indicated that Polish also features a subjective resultative construction based on the perfective adverbial participle (Wiemer \& Giger 2005: 123). Generally, the line between the passive and the resultative is drawn with the help of auxiliaries: zostać 'become' marks the passive (25), whereas być 'be' is used in the resultative construction (26) - note the parallel to Yiddish vern 'become' and zayn 'be'. The construction mieć 'have' + participle passive (27) is discussed as the only option to form the possessive resultative, although (28) undoubtedly also denotes a situation where the result of the actions affects rather the subject than the object and involves the movement of body parts, which together with the arrangement of clothing - is explicitly mentioned by Wiemer and Giger (2005: 79) as a typical instance of the possessive resultative.

(25) POL Samochód akurat został naprawiony. car-NOM right_now become-PST.3SG.M repair-PTCP.PASS.PERF.NOM.SG.M 'The car has just been repaired.' (cited after Wiemer \& Giger 2005: 70)

(26) POL Samochód jest już naprawiony. car-NOM be-PRS.3SG already repair-PTCP.PASS.PERF.NOM.SG.M 'The car is already repaired.' (cited after Wiemer \& Giger 2005: 70)

(27) POL Od tygodnia mam samochód zepsuty. from week-GEN have-PRS.1SG car-ACC break-PTCP.PASS.PERF.NOM.SG.M 'For a week my car is broken.' (cited after Wiemer \& Giger 2005: 72)

(28) POL Chwyciwszy się pod boki i ostro odrzuciwszy grasp-AP.ANT REFL under flank-ACC.PL and sharply throw-AP.ANT głowę, elfka zadrobiła nogami. head-ACC elf-NOM stomp-PST.3SG.F foot-INSTR.PL 'Arms akimbo and having her head sharply turned aside, the elf started to stomp her feet.' (A. Sapkowski. 2001. Chrzest ognia)

For German, Litvinov and Nedjalkov (1988) offer the most comprising description of the resultative constructions. Their findings are on an empirical basis,

8 We refrain from describing the interaction of aspect and voice with Polish participles and the implied readings, as this is not relevant for answering the research question of this paper. 
as they asked native speakers of German to judge the acceptability of examples (and/or their transformations) from the belles lettres (cf. Litvinov \& Nedjalkov 1988: 15-23). However, it has to be mentioned that quite many of the test items are from the 19th or the first half of the 20th century and thus do not necessarily reflect the current language use. Furthermore, in case the informants rejected the test item, they were not asked what exactly provoked the rejection, so it might well be that some items have been rejected on other grounds than the inacceptability of the resultative construction. "Die Konstruktion sein + PartII [Partizip II - S. B.] ist [...] die kategoriale Basis des deutschen Resultativ"” (Litvinov \& Nedjalkov 1988: 2). Moreover they note that "[d] as deutsche Perfekt mit sein neigt viel stärker zur resultativen Bedeutung als das Perfekt mit haben; anders gesagt, das Resultativ übergreift das Perfekt mit sein paradigmatisch"10 (Litvinov \& Nedjalkov 1988: 2). This complies very nicely with the observation made in section 2.1. that verbs denoting the position of body (parts), i.e. subjective-resultative verbs, form their perfect tense either exclusively with sein 'be' or display regional variation. Additionally, Litvinov and Nedjalkov point out the proneness of verbs of motion and of change of place or position to form subjective resultatives (1988: 33-34). For the possessive resultative Litvinov and Nedjalkov (1988: 40) state that

"[a]ls possessiv-resultativisch werden gewöhnlich [...] Aussagen gedeutet, in denen Bezeichnungen von Körperteilen, Kleidungsstücken und anderen Gegenständen aus dem Bereich der "natürlichen Zugehörigkeit” in charakteristischer Weise vorkommen." [those utterances are usually interpreted as possessive resultatives in which lexemes denoting body parts, pieces of clothing and other objects from the realm of "natural belonging" figure in a characteristic way.] (translation - S. B.)

In detail, these verbs form the following semantic classes: 1) arrangement of clothing on the body (cf. Litvinov \& Nedjalkov 1988:41);2) arrangement of hair (cf. Litvinov \& Nedjalkov 1988: 42); 3) result affecting the (human) body (cf. Litvinov \& Nedjalkov 1988:46); 4) undesired result (cf. Litvinov \& Nedjalkov 1988: 44) and 5) configuration of a mechanism (cf. Litvinov \& Nedjalkov 1988:44);6) picture or label on the surface (of the subject) (cf. Litvinov \& Nedjalkov 1988: 47). The first

9 [the construction sein 'be' + participle II is the categorical basis for the German resultative - S. B.].

10 [the German perfect tense formed with sein 'be' is much more prone to a resultative meaning than the perfect tense formed with haben 'have'; in other words, the resultative forms the paradigmatic superstructure for the perfect tense formed with sein 'be' - S. B.]. 
three classes (29-30) strongly correspond to the classes of subjective-resultative verbs identified by Birzer (2010: 103) for Russian, but for the latter two classes it is not discernible how the result of the action affects the subject (31-32).

$$
\begin{aligned}
& \text { GER hatte Handschuhe über die Finger gezogen } \\
& \text { have-PST.3SG glove-ACC.PL over the finger-ACC.PL cover-PTCPII } \\
& \text { 'He had covered his fingers in gloves.' } \\
& \text { (cited after Litvinov \& Nedjalkov 1988: 41) } \\
& \text { (30) GER wenn man die Hände gebunden hat } \\
& \text { if one-Nom the hand-ACC.PL bond-PTCPII have-PRS.3SG } \\
& \text { 'If one's hands are bonded' } \\
& \text { (cited after Litvinov \& Nedjalkov 1988: 46) } \\
& \text { (31) GER Er [sc. der Roboter] hat keine } \\
& \text { it-NOM robot-NOM have-PRS.3SG NEG.PRON } \\
& \text { Schutzreaktion vorprogrammiert } \\
& \text { protection_mechanism-ACC program-PTCPII } \\
& \text { 'The robot has no protection mechanism installed' } \\
& \text { (cited after Litvinov \& Nedjalkov 1988: 46) } \\
& \text { (32) GER Sie schlagen vor, dass jene gerufen werden, die du } \\
& \text { They suggest to call those } \quad \text { REL.PRON.ACC.PL you-NOM } \\
& \text { auf deinem Fries abgebildet hast } \\
& \text { on your frieze-DAT depict-PTCPII have-PRS.3SG }
\end{aligned}
$$

Since Litvinov and Nedjalkov are mainly interested in the interrelationship between resultative and other diatheses, they do not discuss adverbial participles, although they can also express resultativity, as examples (12-14) show.

Regarding Yiddish resultative constructions, to the best of our knowledge no research has been conducted so far. Although Mark's grammar of Yiddish is very comprehensive and describes the formation of the past tense (cf. section 2.1) in detail, he pays much less attention to the passive and does not address the resultative at all. This is probably due to the fact that grammarians of Yiddish consider the passive construction clumsy and advise to avoid it (cf. Mark 1978: 286), which possibly results also in lack of attention for other diatheses closely related to the passive. As has already been mentioned above, the only hint to be found in the literature is Hall's (1967: 30) statement that Yiddish distinguishes an "apparent passive" formed with zayn 'be' and a "true passive" formed with vern 'become. However, this is not the only strategy to convey resultative meaning, as examples (33-34) with an adverbial participle show. (34) is of special interest, since the participle I, usually signaling simultaneity, is used, but the context allows only a resultative reading. By the way, the verbs in both examples may be considered subjective-resultative. 


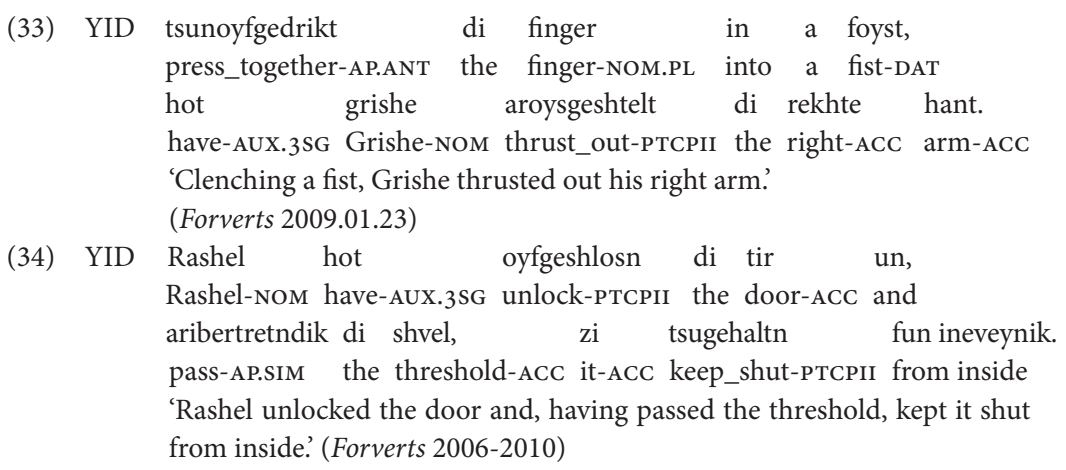

Therefore, the aim of this paper is to explore with the help of corpus data

a) which kind of resultativity is expressed by Yiddish adverbial participles;

b) which semantic classes of verbs figure in the resultative construction with the adverbial participle;

c) whether the usage of participle I vs. participle II correlates with other factors (e.g. verb semantics) or is a phenomenon of mere variation;

d) which con- and divergences with co-territorial languages can be observed.

\section{The Corpus Search}

The empirical data for Yiddish stems from the Corpus of Modern Yiddish, which consists of a newspaper corpus containing roughly 3.1 million tokens, a balanced corpus containing 268 texts ( 1.4 million tokens) mainly from the first half of the 20th century, and a collection of 64 texts (200,000 tokens) by Nokhem Shtif (for a more detailed description of the Corpus of Modern Yiddish cf. Birzer 2014). The search for the participles I and II in the function of adverbial participle was conducted as follows. The search engine does not allow to distinguish between inflected (attributive) and uninflected forms of the participle, so we searched for any instances of the participle I and then manually cleaned the matches from inflected forms. Due to the polyfunctionality of the participle II and the fact that the corpus search engine does not allow to exclude certain lexemes (in our case, the auxiliaries zayn 'be' and vern 'become') from the search, we decided to search for the participle II only in sentence-initial position, as this is the position where an anterior adverbial participle is most likely to occur. The matches were then post-processed manually.

For Polish and Russian the search was easier, as the adverbial participles have dedicated forms. It was thus sufficient to search the Polish and the Russian 
National Corpus for the perfective and the imperfective adverbial participle. The search in the Russian National Corpus was restricted to texts from the main corpus written after 1950. In the case of the imperfective adverbial participle we excluded the lexemes POL mówić 'say, speak' and RUS govorit' 'say, speak' from the search, since they do not imply a change of state and their adverbial participles form the basis for a whole range of frequently used, lexicalized discourse structuring elements. The matches were then post-processed manually.

\section{The Data}

\subsection{Yiddish}

The Yiddish corpus data allows to identify seven semantic classes of verbs that form resultative constructions with the adverbial participle. Four of them concern the (human) body, one the mental state, one class comprises states of nonhuman bodies, and the last class denotes missing results.

Of the four verb classes concerning the (human) body we will first discuss those classes where the resulting state pertains to the whole body. The first verb class denoting positions of the body is characterized by an agentive first argument that controls the body movement leading to the resulting position. Although the majority of instances is formed with the participle II (35-36), the usage of the participle I is also attested in a context requesting a resultative reading (37). The verbs denoting positions or movements of the body all have an agentive first argument, which makes the usage of the participle I possible in the first place. If we then compare examples (35-36) with example (37), episodicity makes the difference: the former two examples are episodic, whereas the latter one is non-episodic and rather generic, i.e. the described actions may occur repeatedly with different persons. We may thus assume that the participle I is chosen to mark iterativity of the action zikh shteln af di kni 'to get on one's knees' and the resulting state.

(35) YID ongeboygn over ir, iz geshtanen an alte froy. bend-AP.ANT above her be-AUX.3SG stand-PTCPII an old woman-NOM 'Bending over her, stood an old woman.' (Forverts 2007.03.23)

$$
\begin{aligned}
& \text { YID avekgeleygt zikh oyf der sofe un farleygt } \\
& \text { lie_down-AP.ANT REFL on the sofa-DAT and fold-AP.ANT } \\
& \text { di hent ahintern aksl, kukt an ore'n. } \\
& \text { the arm-ACC.PL behind shoulder-DAT look-PRS.3SG at Ore-DAT } \\
& \text { 'Having laid down on the sofa and folded his arms behind the shoulders, } \\
& \text { he looks at Ore.' (Kobrin Leon, Dramatishe shriftn) }
\end{aligned}
$$




$$
\begin{aligned}
& \text { YID pruvt zikh der gezelshaftlekher mentsh tsu farbindn } \\
& \text { try-PRS.3SG REFL the social-NOM human-NOM to link-INF } \\
& \text { di ekn, [...] shtelndik zikh af di kni } \\
& \text { the extremity-ACC.PL get REFL on the knee-DAT.PL } \\
& \text { far zeyn eygener shafung. } \\
& \text { for his own-DAT creation-DAT } \\
& \text { 'The social man tries to link together the extremities, getting on his knees } \\
& \text { for his own creation.' (Hantbukh far antireligiezer propagande) }
\end{aligned}
$$

With the verbs denoting physical states only the participle II is attested (38-39). Example (38) features a context that implies the repeated occurrence of the state 'being black and tired', but in contrast to (37), the subject has the status of patient with both farshvartsn 'become black' and oysmatern 'exhaust', which makes the usage of the participle I impossible. Unfortunately, the corpus search did not provide examples of verbs denoting physical states that require an agentive argument, which then becomes the subject of the adverbial participle construction.

$$
\begin{aligned}
& \begin{array}{lllll}
\text { YID farshvartst } & \text { un oysgematert, flegt } & \text { er } \\
\text { become_black-AP.ANT } & \text { and } & \text { exhaust-AP.ANT } & \text { be_used-PRs.3sG } & \text { he }
\end{array} \\
& \text { zikh }[\ldots] \text { opbodn in der [...] balye. } \\
& \text { REFL take_a_bath-INF in the tub-DAT } \\
& \text { 'Sooty and exhausted, he is used to taking a bath in the tub.' } \\
& \text { (Forverts 2007.03.02) }
\end{aligned}
$$

YID geblibn $\quad$ aleyn, hot
remain-AP.ANT alone have-AUX.3SG the child-NOM REFL
farklibn in der lozhe...
hide-PTCPII in the loge-DAT
'Having remained on his own, the child hid in the loge.' (Forverts
2008.01.04)

The verbs denoting the positioning of body parts require the 'owner' of the body parts as agentive first argument, and the body parts as patient second argument, usually encoded as direct object. Interestingly, roughly half of all evidenced instances with resultative meaning are formed with the help of the participle I (40-44). Some verbs, namely aroplozn 'let down' and ayngrobn 'dig in' are attested with the participle I (but not the participle II) several times, so at first glance one might assume that they are lexicalized petrifications. However, they occur with different object lexemes (40-41), and aroplozn dem kop 'hang (lit. let down) one's head' even has the synonym aropleygn dem kop 'hang (lit. put down) one's head' (42), which is also used in the form of participle I. On second inspection, it turns out that all verbs used as participle I are mutative, i.e. in comparison to the starting point, a change of state and thus a result can already be observed even when the action leading to the result has not yet 
reached its end. Therefore, the action leading to the respective result, the result of the (already partially executed) action and the action denoted by the matrix verb may take place simultaneously. With the verbs in the form of participle I (45-47), in contrast, the change of state und thus the result does not take place until the respective telic action has come to its end. This difference may explain why the former group of verbs may occur with the participle I in the function of adverbial participle, whereas the latter group features the participle II in the same function.

(40) YID aroplozndik dem kop [...] oyf di farfetste latsn, let_down-AP.SIM the head-DAT onto the torn-DAT lapel-DAT hot er zikh ongehoybn aroptsulozn

have-AUX.3SG he REFL begin-PTCPII let_down-INF fun di balemer-treplekh.

from the lectern_stairs-DAT

'Bowing his head to the torn lapel, he began to step down from the lectern stairs.'

(Vaysenberg Itshe Meyer, Geklibene verk)

(41) YID ... zey hobn zikh opgeshtelt, aroplozndik

they have-AUX.3PL REFL stop-PTCPII let_down-AP.SIM

zeyere fliglen.

their wing-ACC.PL

'They stopped, letting down their wings.' (Yehoyesh, Tanakh: Yekheskl)

(42) YID aropleygndik zayn kop iz aropgefaln put_down-AP.sIm his head-ACC be-AUX.3SG fall_down-PTCPII dos dekl fun zayn tfilen-shel-yad...

the lid-NOM of his tefillin_case-Dat

'Putting down his head, the lid of his tefillin case fell down.' (Katle Kanye, Der shirem)

(43) YID ... flegt reytshel [...], shoyn zitsndik oyfn divandl, be_used-PRS.3SG Rachel-Nom already sit-AP.SIM on sofa-DAT ayngrobndik zikh mit di fis in der bernfel, dig-AP.SIM REFL with the foot-DAT.PL into the bearskin-DAT zikh posmakeven mit dem biterlekhn getrank [kave-S. B.]. REFL taste-INF with the bitter-DAT drink-DAT 'Already sitting on the sofa, digging her feet into the bearskin, Rachel is used to tasting the coffee.' (Forverts 2008.03.14)

(44) YID ... oyfefenendik di halb-oysgeloshene oygn, open-AP.SIM the half_going_out-ACC eye-ACC.PL hot zi mit shrek gekukt oyf undz. have-AUX.3SG she with fear-DAT look-PTCPII at us 'Opening the half-dying eyes, she looked at us in fear.' (Perets Yitskhok-Leyb, Briv un redes fun Y.L. Perets) 
(45)

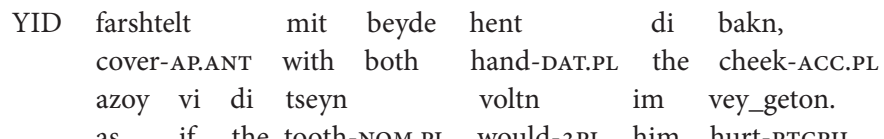

as if the tooth-NOM.PL would-3PL him hurt-PTCPII

'The cheeks covered with both hands, as if his teeth hurted.'

(Kobrin Leon, Dramatishe shriftn)

(46)

\begin{tabular}{|c|c|}
\hline \multirow[t]{4}{*}{ YID } & $\begin{array}{lllll}\text { tsunoyfgedrikt } & \text { di } & \text { finger } & \text { in } & \text { a foyst, } \\
\text { press together-AP.SIM } & \text { the } & \text { finger-NOM.PL } & \text { into } & \text { a fist-DAT }\end{array}$ \\
\hline & aroysgeshtelt di rekhte hant. \\
\hline & have-AUX.3SG Grishe-NOM thrust_out-PTCPII the right-ACC arm-ACC \\
\hline & 'Clenching a fist, Grishe thrusted out his right arm.' (Forverts 2009.01.23) \\
\hline \multirow[t]{7}{*}{ YID } & oykh, arayngerukt ir vild \\
\hline & Lucy-NOM sleep-PRS.3SG also slip_in-AP.ANT her wildly \\
\hline & tsvishn der mame'n un \\
\hline & tousled-ACC little_head-ACC between the mother-DAT and \\
\hline & der mume'n $[\ldots]$ \\
\hline & unt-DAT \\
\hline & $\begin{array}{l}\text { sled little head slipped betwe } \\
\text { strit) }\end{array}$ \\
\hline
\end{tabular}

The verbs denoting the arrangement of clothes have an agentive first argument and the clothes as patient object, which allows the participle I in the function of adverbial participle. Its covert subject is co-referent to an agentive argument of the matrix verb. The arrangement of clothes is a non-mutative action, i.e. the result is discernible only after completion of the action. With the exception of example (48), which describes a situation taking place repeatedly, all instances of these verbs feature the participle II (49-51); the usage of the participle I as adverbial participle clearly marks the simultaneity of the actions (52).

$$
\begin{aligned}
& \text { (48) YID ...flegt zi, aropnemendik dem vaysn khalat, } \\
& \text { be_used-PRS.3SG she take_off-AP.SIM the white-ACC coat-ACC } \\
& \text { shpanen mit shtile trit vi shvebndik } \\
& \text { stride-INF with gentle-DAT.PL step-DAT.PL like float-AP.SIM } \\
& \text { fun der laboratorye tsum es-tsimer [...] } \\
& \text { from the laboratory-DAT tolthe dining-room-DAT } \\
& \text { 'Taking down the white coat, she usually strides with gentle steps, as floating, } \\
& \text { from the laboratory to the dining- room. (Lebns-Fragen 2006.11-12) } \\
& \text { (49) YID farrokhtn oyfn kop zayn hitl, hot er } \\
& \text { place-AP.ANT on/the head-DAT his hat-ACC have-AUX.3SG he } \\
& \text { zikh gelozt tsu der tir [...] } \\
& \text { REFL move-PTCPII to the door-DAT } \\
& \text { 'Having placed his hat on his head, he moved towards the door.' } \\
& \text { (Forverts 2007.03.02) }
\end{aligned}
$$


(50) YID farviklt in shmates, geyen zey bakumen dos clad-AP.ANT in rags-DAT go-PRS.3PL they get-INF the bisl pamoyes eyn_mol in tog [...] bit_of slop-ACC once in day-DAT 'Clad in rags, they go to get the bit of slop once per day.' (Forverts 2007.01.12)

(51) YID ongeton in a khasene-kleyd ligt zi oyf der erd [...] clad-AP.ANT in a wedding_dress-DAT lie-PRS.3SG she on the floor-DAT 'Clad in a wedding dress, she is lying on the floor.' (Forverts 2008.12.12)

YID ontuendik dem ontsug, hot er getrakht, put_on-AP.SIM the suit-DAT have-AUX.3SG he think-PTCPII az er hot nokh bay zikh toyznt rubl [...] that he has with him a thousand roubles 'Putting on the suit, he thought that he has on him a thousand roubles.' (Bergelson Dovid, In a fargrebter shtot)

The verbs denoting mental states figure in the form of the participle II, which is not too surprising given their bidiathetical status (see the discussion of bidiathetical resultatives on the basis of example (18), which also denotes a mental state).

$\begin{array}{lllll}\text { YID } & \text { fartift, } & \text { er zet } & \text { mikh nisht. } \\ \text { absorb-AP.ANT } & \text { he see-PRS.3SG } & \text { me } & \text { not } \\ & \text { 'Absorbed, he does not notice me.' } & \\ \text { (Perets Yitskhok-Leyb, Der meshugener batlen) } \\ \text { YID } & \text { dershtoynt } & \text { muz } & \text { ikh } & \text { aroysrufn: } \\ & \text { stun-AP.ANT } & \text { must-PRS.1SG } & \text { I } & \text { cry_out-INF }\end{array}$

oykh du brutus - Et tu Brute?

And you too, Brutus - Et tu Brute?

'Stunned, I need to cry out: And you too, Brutus - Et tu Brute?'

(Forverts 2006-2010)

(55) YID dershitert fun dem alem farlozt or di shtub [...] shock-AP.ANT from this-DAT all-DAT leave-PRS.3SG he the room-ACC 'Shocked by all this he leaves the room.' (Lebns-Fragn 2008.03-04)

Of the verb class denoting states that do not pertain to the human body or mind only very few examples are attested, but it is very interesting that in cases where the first argument of the matrix sentence is patient of the action denoted by the adverbial participle construction, the duration of the resulting state is stressed by forming an adverbial participle of the auxiliary zayn 'be' from the prototypical resultative construction zayn + participle II (56). If the semantic role of the respective argument is located closer to agentivity, the participle I is chosen to mark duration of the given state (57). 
(56)

$$
\begin{aligned}
& \text { YID zeyendik filshtendik tseshtoybt un opgerisn eyner fun } \\
& \text { be-AP.SIM completely disperse-PTCPII and cut_off-PTCPII one from } \\
& \text { tsveytn, [...] hobn dokh di pueli-tsiyen tsentrn [...] } \\
& \text { second-DAT have-AUX.3PL yet the Poyle-Tsiyen center-NOM.PL } \\
& \text { areysgerukt enlekhe hanokhes [...] } \\
& \text { bring_forward-PTCPII similar premise-ACC.PL } \\
& \text { 'Being completely dispersed and cut off from one another, the Poyle- } \\
& \text { Tsiyen centers nonetheless made available similar premises.' } \\
& \text { (Zrubovl Yankev, Yidisher arbeter pinkes tsu der geshikhte fun der Poyle- } \\
& \text { Tsiyen bavegung) } \\
& \text { 57) YID ... dan flist zayn vaser [...] tsvishn di shteyner [...], } \\
& \text { then flow-PRS.3SG its water-NOM between the stone-DAT.PL } \\
& \text { zikh badekndik mit a vaysn shoym. } \\
& \text { REFL cover-AP.SIM with a white foam-DAT } \\
& \text { 'Then its water flows between the stones, covered in white foam.' } \\
& \text { (Khayimson M., Fizishe geografye driter un ferter lernyor) }
\end{aligned}
$$

The last group which marks missing results is a "mixed bag" in the sense that any telic verb implying a transformation and accompanied by the negation nit 'not' becomes a member of this group. The missing result is usually encoded with the help of the participle I functioning as adverbial participle (58).

$$
\begin{aligned}
& \text { YID yashe hot }[\ldots] \text { zikh mit a zayt aroysgeshart funem } \\
& \text { Yashe-NOM have-AUX.3SG REFL with one side get_out-PTCPII from\the } \\
& \text { tsimer, nisht opraysndik fun der baleboste } \\
& \text { room-DAT not tear_away-AP.SIM from the landlady-DAT } \\
& \text { di oygn [...] } \\
& \text { the eye-ACC.PL } \\
& \text { 'Yashe moved out of the room with one side of his body, not tearing his } \\
& \text { eyes away from the landlady'. (Forverts 2008.03.07) }
\end{aligned}
$$

To summarize, seven semantic classes of verbs express resultativity with the help of the adverbial participle. Which participle is chosen depends on the semantics of the verb and thus the semantic roles of its arguments as well as on the aktionsart. Regarding semantic roles, agentivity of the covert subject of the adverbial participle makes the occurrence of the participle I more likely, whereas the semantic role of patient fosters the usage of the participle II.

Verb stems with bidiathetical potential, such as the mental state verbs, take the form of the participle II. The usage of the participle II is also in line with the punctuality of the denoted action, e.g. farshrekn 'frighten', which does not allow to observe the process of change and thus makes the usage of the participle I rather unlikely. 
On the other hand, mutative verbs, which allow to observe the change of state, seem to prefer the participle I. Just as well, missing results and states other than those of the human body or mind are prototypically encoded with the participle I, which stresses the duration of the respective (missing) state. All other discussed verb classes prototypically use the participle II in the function of the adverbial participle to express resultativity and seem to resort to the participle I only in cases where an interative or generic reading needs to be marked.

\subsection{Polish and Russian}

The Polish and Russian corpus data allowed to identify eight verb classes that form their subjective resultative with the help of the adverbial participles. Among them are the seven classes already described for Yiddish, namely four classes concerning the (human) body, mental state, states of non-human bodies and missing results. The class not attested for Yiddish is constituted by verbs denoting actions with objects that are (being) positioned close to the (human) body (one might discuss whether this class can be merged with the class denoting the arrangement of clothing). Thus this class may be integrated into the 'inner circle' of subjective resultative verb classes denoting states pertaining to the human body. Let us now consider which adverbial participle is used to convey resultativity.

The verb class denoting the position of the (human) body conveys the subjective resultative predominantly with the perfective adverbial participle marking anteriority of the action (59-62).

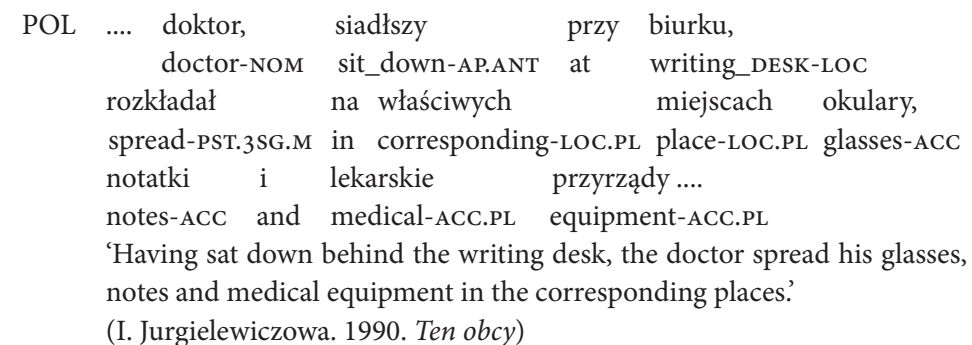

(60)
POL Włączył
dyktafon
i wychyliwszy
się
switch_on-PST.3SG.M voice_recorder-ACC and lean_over-AP.ANT REFL
$\begin{array}{llll}\text { za balustradę, } & \text { powoli } & \text { opuścił } & \text { go .... } \\ \text { over balustrade-ACC } & \text { slowly } & \text { let_down-PST.3SG.M } & \text { it-ACC }\end{array}$
'He switched on the voice recorder and, leaning over the balustrade, slowly let it down.' (Z. Górniak. 2009. Siostra i byk) 
(61)

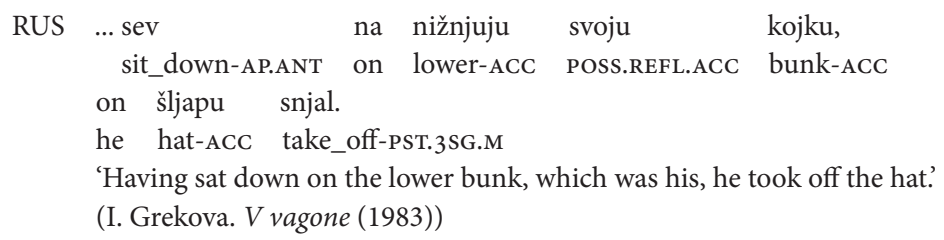

(62)

$\begin{array}{llll}\text { RUS Ustal } & \text { i } & \text { zasnul, } \\ & \text { get_tired-PST.3SG.M } & \text { and } & \text { fall_asleep-PST.3SG.M }\end{array}$

prislonivšis' $\mathrm{k}$ stvolu.

lean-AP.ANT to trunk-DAT

'He got tired and fell asleep, leaning on a trunk.'

(A. Dorofeev. Ėle-Fantik // «Murzilka», 2003)

In Russian, the imperfective adverbial participle is used only in non-resultative contexts, i.e. when two actions take place simultaneously (63), and in those rare cases where the iterativity of the resulting state needs to be stressed (64).

$$
\begin{aligned}
& \text { RUS - Vy peškom? - sprosil, sadjas' na narach. } \\
& \text { you on_foot ask-PST.3SG.M sit_down-AP.SIM on pallet-LOC } \\
& \text { '"You've walked?" he asked, sitting down on the pallet.' } \\
& \text { (V. Remizov. Volja volnaja // «Novyj mir», 2013) }
\end{aligned}
$$

\begin{tabular}{llll} 
RUS Sadjas' & \multicolumn{1}{c}{ užinat' } & $\mathrm{v}$ gostjach, & Šachurina \\
& sit_down-AP.SIM have_dinner-INF & at guest-LOC.PL & Šachurina-NOM \\
pervym delom & perevoračivala & tarelku i \\
first-INSTR & deed-INSTR & turn_over-ITER.PST.3SG.F & plate-ACC and
\end{tabular}

The Polish corpus data provides several instances with the imperfective adverbial participle that make a simultaneous or iterative reading rather unlikely (65-66). This complies with Feret's finding that that the type number of the perfective adverbial participle is decreasing in favor of the imperfective one (cf. Feret 2005: 37). Indeed, a very provisional corpus search for the adverbial participles siadajac-IPF vs. usiadłszy-PF 'sitting/having sat down' and wychylajac-IPF vs. wychyliwszy-PF 'leaning/having leant out' (irregardless of the function in the given contexts) showed that the ratio is roughly $8.7: 1$ and $3.6: 1$ respectively. Another issue with the aspectual pair siadać-IPF/usiasść-PF is the irregular perfective adverbial participle usiadtszy-PF, which might foster the preferred usage of the regular imperfective adverbial participle. From a semantic point of view, wychylać 'lean out' is a gradual action and maintaining the degree of the gradual 
action takes the same effort as reaching it. These factors might also favor the usage of the imperfective adverbial participle.

(65) POL - Serwus!-zawołała Pestka, siadając na parapecie Hello call-Pst.3Sg.F Pestka-Nom sit-AP.SIM on window_sill-Loc i przerzucając nogi na zewnątrz. and toss-AP.SIM feet-ACC to outside

"'Hello!" Pestka called, sitting on the window sill and tossing her feet out on the street.' (I. Jurgielewiczowa. 1990. Ten obcy)

(66) POL Zdaje_się, że był jakiś wypadek - powiedział seem-PRS.3SG that was some-NOM accident-NOM say-PST.3SG.M Marczyński, wychylając się przez drzwi. Marczyński-NOM lean_out-AP.SIM REFL through door-ACC "'It seems there has been an accident," Marczyński said, leaning out of the door'. (M. Wolski. 2003. Alterland)

With verbs denoting the position of body parts the situation is roughly the same as above. In Russian, only the perfective adverbial participle of telic verbs is used to mark resultativity (67-69); the imperfective adverbial participle signals the simultaneity of actions (70) or the iterative occurrence of a certain result (71). With the atelic verb chmurit'sja 'frown' the effort of maintaining the facial expression is the same as initializing it, which may explain the usage of the imperfective adverbial participle (72).

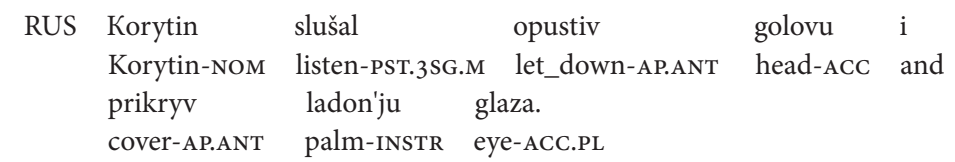

'Korytin was listening with his head hanging down and his eyes covered by his palm.' (B. Ekimov. Pinočet (1999))

(68) RUS Ja,

I-NOM close-AP.ANT eye-ACC.PL can-PRS.2SG on feeling-ACC skol'zit' pal'cem po nosu ... slide-INF finger-INSTR along nose-DAT 'With my eyes closed, I can slide my finger along the nose just on feeling.' (S. Spivakova. Ne vsë (2002))

(69) RUS Podnjav ruku, ona doždalas', raise-AP.ANT hand-ACC she wait-PST.3SG.F kogda avtomobil' ostanovitsja ... when car-NOM stop-FUT.3SG 'Raising her hand, she waited until the car would stop ...' (A. Gelasimov. Dom na Ozernoj (2009))

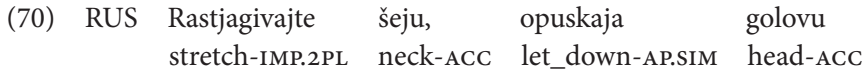




$$
\begin{array}{llllll}
\text { vse niže } & \text { i } & \text { niže } & \text { na } & \text { grud'. } \\
\text { ever } & \text { lower } & \text { and } & \text { lower } & \text { onto } & \text { breast-ACC }
\end{array}
$$

'Stretch your neck, letting your head ever lower and lower down on your breast.' (S. Makeev. Pro družbu s golovoj (2002) // «Domovoj», 2002.08.04)

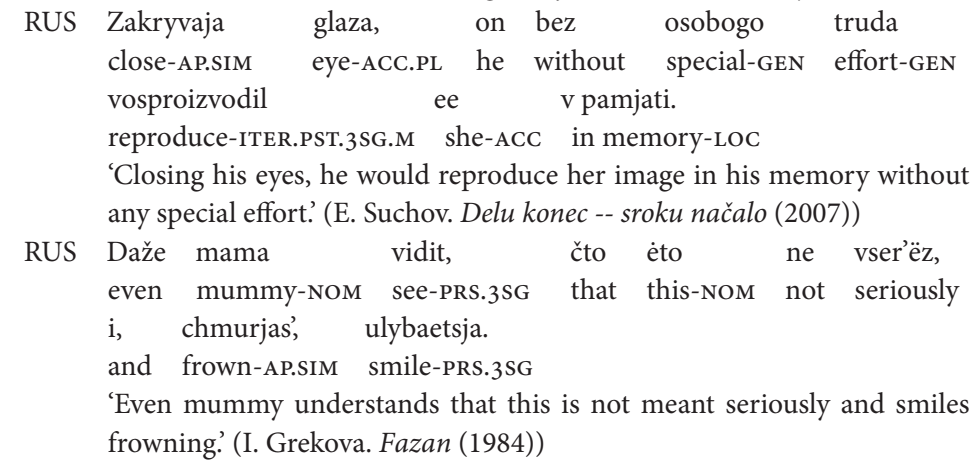

In Polish, the semantic criterion of taking maintenance efforts seems to outweigh the telicity criterion, as both atelic (73) and telic (74-75) verbs may occur in the imperfective form. With wtulać 'cuddle' it is unclear whether efforts need to be taken to maintain the situation; interestingly, this verb is also attested in both the imperfective (76) and the perfective (77) form. Telic verbs that require different efforts for initializing and maintaining the situation (or none at all for the latter) are attested in the form of perfective adverbial participle only (78-79).

$$
\begin{aligned}
& \text { POL ... spoglądał właśnie w niebo, } \\
& \text { look-PST.3SG.M just in sky-ACC } \\
& \text { mrużąc oślepione słońcem oczy. } \\
& \text { squint-AP.SIM blind-PTCP.PASS.ACC.PL sun-INSTR eye-ACC.PL } \\
& \text { '... he just looked at the sky, squinting his eyes blinded by the sun.' } \\
& \text { (I. Jurgielewiczowa. 1990. Ten obcy) }
\end{aligned}
$$

(74) POL Zabijcie mnie...-jęczał rwanymi

kill-IMP.2PL me groan-PST.3SG.M disrupted-INSTR.PL

wyrazami, rozwierając nabrzmiałe wargi ....

phrase-INSTR.PL open-AP.SIM swollen-ACC.PL lip-ACC.PL

"'Kill me," he groaned in disrupted phrases, opening his swollen lips.'

(Zd. Smektała. 2006. Chcica czyli Billie Holiday to kurwa: poemat romantyczny)

(75) POL Wyglądała tak, jakby ... zasnęła,

look-PST.3SG.F so as_if fall_asleep-PST.3SG.F

wtulając twarz w piasek.

cuddle-AP.sim face-ACC into sand-ACC 
'She looked as if she had fallen asleep, cuddling her face into the sand.'

(M. Krajewski; M. Czubaj. 2009. Róże cmentarne)

(76)

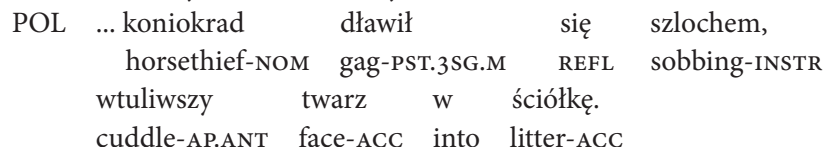

'The horsethief gagged on sobbing, cuddling his face into the litter.'

(A. Sapkowski. 2001. Chrzest ognia)

(77)
POL $\quad \ldots \quad$ odchyliwszy
głowę
do tyłu
throw_back-AP.ANT head-ACC to back_of_the_head-GEN
zaniósł się rechotliwym śmiechem.
start-PST.3SG.M REFL croaking-INSTR laughter-INSTR
'Throwing back his head he started to laugh croakingly'
(M. Tomaszewska. 2001. Zorro, załóż okulary!)

(78)

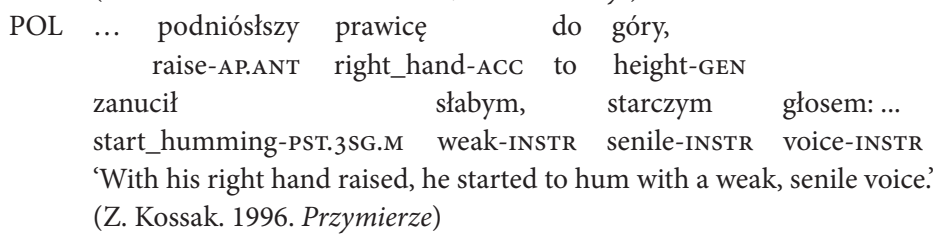

With resultative meaning, the class of verbs denoting the arrangement of clothes is evidenced only in the form of the perfective adverbial participle in both Russian (79-80) and Polish (81-82).

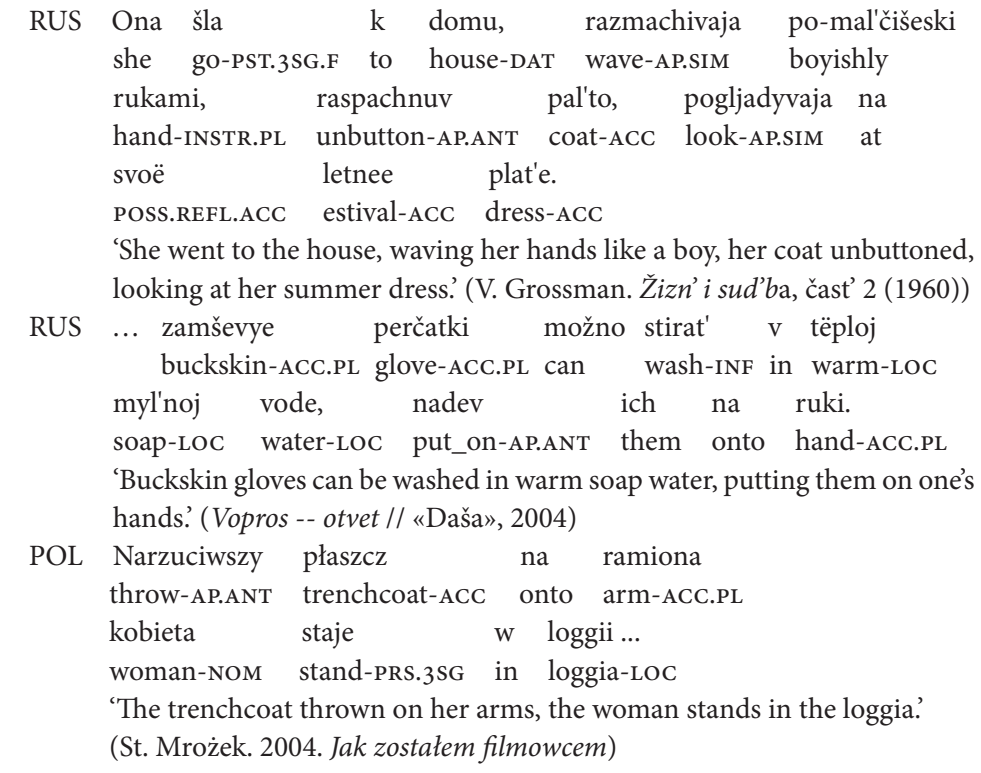


(82)

$$
\begin{aligned}
& \text { POL } \quad . . \quad \text { zdjąwszy beret pokłoniłem się głęboko ... } \\
& \text { take_off-AP.ANT cap-ACC bow-PST.1SG.M REFL deeply } \\
& \text { 'Having taken off my cap, I made a deep bow.' (J. Krzysztoń. 1983. Obłęd) }
\end{aligned}
$$

The same holds also for the verbs denoting the contact with objects close to the human body (83-84), which is more evidence for their closeness to the verbs denoting the arrangement of clothing.

$\begin{array}{llll}\text { POL } & \ldots \quad \text { sięgnąwszy } \quad \text { po kubek zaczął } & \text { pić } \\ \text { grasp-AP.PF after cup-ACC } & \text { start-PST.3SG.M } & \text { drink-INF } \\ \text { małymi tykami. } & & \\ \text { small-INstr gulp-INSTR } & & \\ \text { 'Having grasped the cup, he started to drink in sips.' } & \\ \text { (I. Jurgielewiczowa. 1990. Ten obcy) }\end{array}$

$(84)$

RUS No ona, schvativ ego za ruku,
but she grasp-AP.ANT him after hand-ACC
ne pustila.
not let_in-PST.3SG.F
'But she, grasping his hand, did not let him in.'
(Ju. Trifonov. Dom na naberežnoj (1976))

For the verbs conveying mental states only perfective adverbial participles are attested with resultative meaning (85-88), probably because changes of the mental state take place rather momentarily. Quite obviously, the construction consisting of the auxiliary POL być 'be' and RUS byt' 'be' respectively as adverbial participle and the participle passive of the main verb stresses the durativity of the resulting situation, but this construction deserves special attention also for another reason. A small excursus will explain why.

The combination of auxiliary and participle passive is the prototypical objective resultative construction in many languages of the world. As we have seen above, Yiddish, just like German, features verb pairs that differ regarding reflexivity and thus (in)transitivity and that both form their resultative with the help of this construction, which is then called bidiathetical. Wiemer and Giger claim the same for the Slavonic languages (2005: 13; cf. also section 2.2.), and examples (89-91) substantiate this.

However, in contrast to Yiddish and German, this is not the only way how the reflexive verb can express (subjective) resultativity - it may also recur to the adverbial participle (92-94). Since the adverbial participle is perfective, we may also exclude a transposition of the Slavonic dynamic passive, as it may occur only with the imperfective aspect. Note also that the state conveyed by the adverbial participle is evoked by active involvement in the preceding situation, i.e. the situation is related in the mode of direct evidentiality, whereas this remains 
unspecified with the passive participle. Therefore, we may state that the construction with the adverbial participle is specified for subjective resultativity, active voice and direct evidentiality, whereas the construction with the passive participle lacks such specifications.

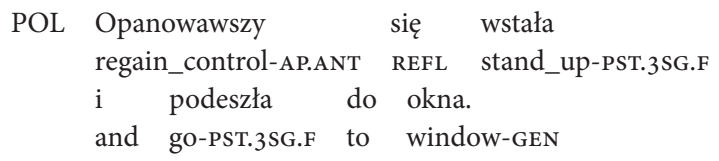

'Having regained control over herself, she got up and went to the window' (I. Jurgielewiczowa. 1990. Ten obcy)

86) POL Joanna pogodziwszy się z otoczeniem..... Joanna-NOM resign-AP.ANT REFL with surroundings-INSTR nie szukała ze mną wspólnego języka. not seek-PST.3SG.F with me common-GEN language-GEN 'Joanna, having resigned herself to the circumstances, did not seek a common language with me.' (Ja. Głębski. 2006. Droga do Ite)

(87) RUS Porazivšis' i smutivšis' ..., be_astonished-AP.ANT and be_bewildered-AP.ANT ja ničego ne otvetila... I nothing-GeN not answer-PST.1SG 'Astonished and bewildered, I did not answer.' (O. Zueva. Skaži, čto ja tebe nužna... // «Daša», 2004)

(88) POL Inni dumnie obnosili wypielęgnowany brąz, Other-NOM.PL proudly display-PST.3PL well_tended-ACC bronze_tone-ACC będąc przekonani o swej be-AP.SIM convince-PTCP.PASS.NOM.PL of POSS.REFL.LOC atrakcyjności. attractivity-LOC

'Other people flaunted their well-tended bronze tone, being convinced of their attractivity'. (M. Krajewski; M. Czubaj. 2009. Róże cmentarne)

(89) POL Piotr, przekonawszy się, że te zarzuty Peter-NOM convince-AP.ANT REFL that these accusation-NOM.PL dotarly do wszystkich gmin rzymskich, reach-PST.3PL to all-GEN.PL parish-GEN.PL Roman-GEN.PL postanowił skończyć $\mathrm{z}$ nimi raz na zawsze. decide-PST.3SG.M stop-INF with them once for ever 'Peter, having convinced himself that these accusations had reached all Roman parishes, decided to do away with them once and for all: (Jan Dobraczyński. 1946. Święty miecz)

(90) RUS Tret'jakov pristupil k sobiratel'stvu ..., Tretyakov-NOM commence-PST.3SG.M to collecting-DAT buduči ubežden, čto iskusstvo Rossii be-AP.SIM convince-PTCP.PASS.M that art-NOM Russia-GEN 
nachoditsja na poroge nacional'nogo samoutverždenija .... be_situated-PRS.3SG on verge-LOC national-GEN self-affirmation-GEN 'Tretyakov commenced his collection being convinced that the Russian art is on the verge of national self-affirmation.'

(Ja. Bruk. «Sobrat' russkuju školu, kak ona est'...». K 150-letiju Gosudarstvennoj Tret'jakovskoj galerei // «Nauka i žizn'», 2006)

$(91)$
RUS ... ubedivšis', čto ego nikto ne taščit convince_oneself-AP.ANT that him nobody-N $\mathrm{n}$
na dno on poplyl
$\mathrm{k}$ protivopoložnomu pomostu.
to ground-ACC he swim-PST.3SG.M to opposite-DAT rack-DAT 'Having convinced himself that nobody was dragging him to the ground, he swam to the opposite rack.' (F. Iskander. Moj kumir (1965-1990))

RUS
... neskol'ko ran'še ja perestal s nim zdorovat'sja, a_bit earlier I stop-PST.1SG.M with him greet-INF buduči razozlen gruboj stat'ej be-AP.SIM incense-PTCP.PASS.M rude-INSTR article-INSTR

v «Litgazete»...

in Litgazeta-LOC

'Somewhat earlier I had stopped to greet him, being incensed by a rude article in the "Litgazeta".

(S. B. Rassadin. Kniga proščanij. Vospominanija o druz'jach i ne tol'ko o nich (2004-2008))

(93)
RUS Razozlivšis', passažiry zarezali mužčinu ... become_incensed-AP.ANT passenger-NOM.PL stab-PST.3PL man-ACC 'Incensed, the passengers stabbed the man.' (Ju. Muchina. Taksistov grabila «zolotaja molodež» (2002) // «Večernjaja Moskva», 2002.05.16)

The next class of verbs denotes various states that can be subsumed under the label human condition. Only perfective adverbial participles are attested with this verb class. This may be explained by the fact that (probably with the exception of zmęczyć się 'get tired' (94)) the manifestation of the resulting state is not scalar (i.e. you are either widowed or not (95), have rested well or not (96), etc.) and the underlying change is thus either considered unimportant or is not perceived as a gradual, mutative process.

$\begin{array}{lllll}\text { (94) POL } & \ldots \text { zmęczywszy } & \text { się } & \text { odjął } & \text { stopę ... } \\ & \text { become_tired-AP.ANT } & \text { REFL } & \text { take_away-PST.3SG.M } \\ \text { foot-ACC }\end{array}$


I knew many amazing people who, having been widowed, married again.' (J. Grzegorczyk. 2009. Chaszcze)

$\begin{array}{lllll}\begin{array}{l}\text { Inogda } \\ \text { Sometimes } \\ \text { bodrstvovala }\end{array} & \begin{array}{l}\text { ona, } \\ \text { she }\end{array} & \begin{array}{c}\text { vyspavšis' } \\ \text { rest_well-AP.ANT } \\ \text { nočju ... }\end{array} & \text { in } & \text { siestu, } \\ & & & \end{array}$

be_awake-PST.3SG.F at_night

'Sometimes, having rested well during the siesta, she was awake at night.' (T. Orlova. Lovuška dlja jaščeric // «Oktjabr»», 2003)

Finally, the last group of missing results is again a mixed bag in the sense that verbs of any semantics and aspects may occur, given they are negated. For the states resulting from gradual processes, both the perfective (97-98) and the imperfective (99-100) adverbial participle is possible, whereas states involving punctual changes are attested only with the perfective adverbial participle (101); the imperfective adverbial participle signals iterative absence of the respective result (102).

(97) POL Nie kolaboruje

not collaborate-PRS.1SG with

agresorem -

odparła, nawet się nie odwróciwszy.

answer-PST.3SG.F not_even REFL not turn_around-AP.ANT

"I do not collaborate with the aggressor," she answered, not even turning around.'

(R. Urbański; J. Kondracki. 2009. Operacja „Dunaj“)

(98) RUS
Do svidanija, - skazala
Ksenija
ne obernuvšis',

Goodbye say-PST.3SG.F Ksenija-NOM not turn_around-AP.ANT

'"Goodbye," Ksenija said, not turning around.'
(A. Volos. Nedvižimost' (2000) // «Novyj Mir», 2001)

(99)
POL $\quad \ldots$ nie odwracając
się, $\mathrm{z}$ trudem
wyszeptał: ...
not turn_around-AP.SIM REFL with effort-INSTR whisper-PST.3SG.M

'Not turning around, he whispered with effort: ....'

(Ja. Iwaszkiewicz. 2006. Brzezina i inne opowiadania Kościół w Skaryszewie)
(100) RUS - Sejčas ètot pridët, — ne oboračivajas'
now that-NOM come-FUT.3SG not turn_around-AP.sim
skazala montažnica.

say-PST.3SG.F fitter-NOM

"Now that one is coming," the fitter said, not turning around.'

(G. Ja. Baklanov. V meste svetlom, v meste zlačnom, v meste pokojnom (1995))

(101) RUS $\ldots$ ona $\mathrm{v}$ polumrake načinala novyj den', she in half_light-Loc start-iter.PST.3SG.F new-ACC day-ACC

ne vyspavšis'...

not rest_well-AP.ANT

'In the half-light she used to start the new day, not having rested well...'

(V. Grossman. Žizn' i sud'ba, čast' 3 (1960)) 


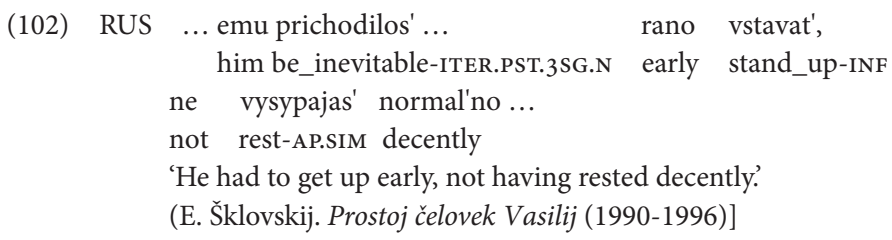

To summarize, we may state some differences but also convergences in the usage of the adverbial participle in Polish and Russian. Firstly, both languages prefer the perfective adverbial participle for conveying resultative meaning. Yet the distinction between resultativity and iterativity is more clear-cut for Russian than Polish, as Russian employs the imperfective adverbial participle exclusively for marking iterativity (also of results) or the simultaneity of two actions. The fact that Polish expresses resultativity also with the help of the imperfective adverbial participle complies with Feret's finding that in Polish the token number of the perfective adverbial participle is decreasing in favor of the imperfective one (cf. Feret 2005: 37). If we took Feret's observation as the (only) explanation for the existence of imperfective adverbial participles with resultative reading, the usage of perfective and imperfective adverbial participles with resultative reading would be characterized as an instance of variation. However, verb semantics, namely the denotion of a gradual change of state, determines the usage of the imperfective adverbial participle, so we are dealing with a rule-based phenomenon. An interaction with the increasing general token number of the imperfective adverbial participle, e.g. with analogy as motivating factor, cannot be excluded.

Both Russian and Polish feature several pairs of mental state verbs that are formed with the same morphological stem but differ regarding (in)transitivity. The intransitive verb carries a reflexive marker and has two options for forming the resultative: as with the transitive verb, the bidiathetical construction with auxiliary and participle passive may be used, or the construction with the (perfective) adverbial participle. The latter is employed exclusively with the intransitive verb and is specified for subjective resultativity, active voice and direct evidentiality, whereas the construction with the passive participle lacks such specifications.

Let us now consider the con- and divergences between Yiddish and its coterritorial languages Polish and Russian.

\section{Conclusion}

All three object languages have a prototypical construction for conveying subjective resultative meaning: for Yiddish the usage of the participle II is prototypical, 
both in the construction consisting of finite auxiliary and participle II and as "plain" participle in the function of adverbial participle. Thus, for marking subjective resultativity, Yiddish draws on the same polyfunctional item figuring in two different constructions (of which the latter may be considered an (elliptic) derivation of the former). The Slavonic languages prototypically feature the perfective adverbial participle for expressing subjective resultativity. Very probably, the abstraction from tense and from the active-passive dichotomy makes the adverbial participle - a non-finite verb form that expresses taxis, not tense prone to express resultativity (cf. Maslov 1988: 67-69 on the interaction between aspect, actionality and voice).

The semantic verb classes with subjective resultative meaning coincide for all three languages. Across all languages, the general tendency can be observed that punctual verbs prefer the participle II or perfective adverbial participle respectively; whereas the likelihood for the usage of the participle I or imperfective adverbial participle is higher for verbs denoting gradual changes. Additionally, in Yiddish, the choice of participle I or II depends on the semantics of the verb and thus the semantic roles of its arguments as well as on the aktionsart. Regarding semantic roles, agentivity of the covert subject of the adverbial participle makes the occurrence of the participle I more likely, whereas the semantic role of patient makes the participle II more likely.

Concerning the functional distribution of (adverbial) participles, Russian is the strictest language, as it allows only the perfective adverbial participle for marking resultativity; Polish also features some imperfective adverbial participles with resultative reading. We may thus state a convergence between Yiddish and Polish. Since verb semantics determines in both languages whether the imperfective adverbial participle may bear a subjective resultative reading or not, a convergence by mere accident is rather unlikely. One possible explanation is the daily face-to-face contact of Yiddish and Polish during several centuries. Russian, on the other hand, was the H-language in the Russian Empire, but not necessarily that of daily face-to-face contact with Yiddish, as the Pale of Settlement stretched mainly over Polish, Belarusian, Ukrainian and Lithuanian speaking territories (cf. Bunčić 2006: 81 on the historic language situation in the PolishLithuanian Commonwealth and the Russian Empire). It may be assumed that language contact on a daily face-to-face basis makes convergences much more likely than (literacy) contact with an $\mathrm{H}$-variety hardly used in daily interaction.

Finally, one striking divergence between Yiddish and the other object languages has to be mentioned: all three languages feature several mental state verbs of the same morphological stem that differ regarding (in)transitivity. The intransitive verb has a reflexive marker. In Yiddish, just like in German, these 
intransitive verbs take exclusively the participle II to mark the subjective resultative; since the transitive verbs use this construction as well to mark the objective resultative (also called stative passive), this construction is bidiathetical. One might interpret this as an underspecification regarding voice, as the resultative may be traced back both to the active perfect of the intransitive verb and the passive of the transitive verb. In our Slavonic objectives languages, however, the intransitive mental state verbs have two options for forming the resultative: as with the transitive verb, the bidiathetical construction with auxiliary and participle passive may be used, or the construction with the (perfective) adverbial participle. The latter is employed exclusively with the intransitive verb and is specified for subjective resultativity, active voice and direct evidentiality, whereas the bidiathetical construction with the passive participle lacks such specifications - just as in Yiddish. The absence of the second, specified subjective resultative construction for mental state verbs in Yiddish is a trait characteristic of the Germanic language family, which has not been overcome even in the centurylong language contact with Slavonic.

\section{References}

Birzer, Sandra (2010): Russkoe deepričastie: processy grammatikalizacii i leksikalizacii.[TheRussian adverbial participle:processes of grammaticalization and lexicalization.] München: Otto Sagner.

Birzer, Sandra (2014): Yiddish passive constructions: A Case Study based on the new Corpus of Modern Yiddish. In: Hansen, Björn/Aptroot, Marion (eds.) Yiddish Language Structures. (Empirical Approaches to Language Typology). Berlin/New York: Mouton de Gruyter, 290-321.

Bungarten, Theo (1976): Präsentische Partizipialkonstruktionen in der deutschen Gegenwartssprache. Düsseldorf.

Bunčić, Daniel (2006): Die ruthenische Schriftsprache bei Ivan Uževyč unter besonderer Berücksichtigung seines Gesprächsbuchs Rozmova/Besěda. Mit Wörterverzeichnis und Indizes zu seinem ruthenischen und kirchenslavischen Gesamtwerk (Slavistische Beiträge, 447). München: Otto Sagner.

Feret, Andrzej (2005): Das Partizip im Deutschen und Polnischen. Frankfurt /M.: Lang.

Hall, Richard M. R. (1967): Yiddish syntax: phrase structure rules and optional singulary transformations of the modern standard language. $\mathrm{PhD}$ thesis. New York University.

Haspelmath, Martin (1995): The converb as a cross-linguistically valid category. In: Haspelmath, Martin/König, Ekkehard (eds). Converbs in Cross-Linguistic 
Perspective: Structure and Meaning of Adverbial Verb Forms - Adverbial Participles, Gerunds. Berlin - New York, 1-55.

Knjazev, Jurij P. (1988): Resultative, Passive and Perfect in Russian. In: Nedjalkov, Vladimir (ed.) Typology of resultative constructions. Amsterdam/Philadelphia: John Benjamins, 343-368.

Litvinov, Viktor P./Nedjalkov, Vladimir P. (1988): Resultativkonstruktionen im Deutschen. Tübingen: Gunter Narr.

Mark, Yudl (1978): Gramatik fun der yidisher klal-shprakh. [Grammar of the Yiddish Standard Language]. New York: Congress for Jewish Culture.

Maslov, Jurij S. (1988): Resultative, Perfect and Aspect. In: Nedjalkov, Vladimir P. (ed.) Typology of resultative constructions. Amsterdam/Philadelphia: John Benjamins, 63-85.

Nedjalkov, Vladimir P./Jaxontov, Sergej Je. (1988): The Typology of Resultative Constructions. In: Nedjalkov, Vladimir P. (ed.) Typology of resultative constructions. Amsterdam/Philadelphia: John Benjamins, 3-62.

Nedjalkov, Vladimir P. (ed.) (1988): Typology of resultative constructions. Amsterdam/Philadelphia: John Benjamins.

Rappaport, Gilbert C. (1984): Grammatical Function and Syntactic Structure: The Adverbial Participle of Russian. Columbus: Slavica Publishers.

Švedova Natalija Ju. et al. (1980): Russkaja grammatika [Russian Grammar]. Two volumes. Moscow: Nauka.

Trubinskij, Valentin I. (1988): Resultative, Passive and Perfect in Russian Dialects. In: Nedjalkov, Vladimir P. (ed.) Typology of resultative constructions. Amsterdam/Philadelphia: John Benjamins. 389-409.

Wiemer, Björn/Giger, Markus (2005): Resultativa in den nordslavischen und baltischen Sprachen. Bestandsaufnahme unter arealen und grammatikalisierungstheoretischen Gesichtspunkten. München: Lincom Europa.

Yokoyama, Olga (1984): $V$ zaščitu zapretnych deepričastij. [In defencse of forbidden adverbial participles.] In: Flier, Michael S. (ed.) American Contributions to the Ninth International Congress of Slavists: Kiev, September 1983. vol. I, 373-381.

Zifonun, Gisela/Hoffmann, Ludger/Strecker, Bruno (1997): Grammatik der deutschen Sprache. Band 3. Berlin/New York: Walter de Gruyter. 


\section{Notes on the Authors}

Sandra Birzer - full professor for Slavonic linguistics at the University of Innsbruck. After studying in Regensburg and St. Petersburg, she earned her M.A. in Slavonic and English Studies at the University of Regensburg in 2005. Defense of the $\mathrm{PhD}$ thesis The Russian Adverbial Participle: Grammaticalization or Lexicalization in 2008. From 2014-2016 professor for the Linguistics of West Slavonic languages at Hamburg University. Major works: The dynamics of (inter) change: a panchronic approach to discourse-structuring elements based on non-finite verba dicendi in Slavonic (2015), Russkoe deepričastie: processy grammatikalizacii $i$ leksikalizacii [Das russische Adverbialpartizip. Grammatikalisierungs- und Lexikalisierungsprozesse] (2010), Yiddish passive constructions: A Case Study based on the new Corpus of Modern Yiddish [in] Hansen, Björn / Aptroot, Marion (eds.) Yiddish Language Structures. 290-321 (2014).

e-mail: sandra.birzer@uibk.ac.at

Andrzej Kątny - full professor at the Department of Linguistics and Translation Studies (University of Gdansk). His main research areas are: contrastive linguistics German-Polish, German linguistics, contact linguistics, aspectuality and modality. He is co-editor of four linguistic series by Peter Lang: Danziger Beiträge zur Germanistik; Sprach- und Kulturkontakte in Europas Mitte. Studien zur Slawistik und Germanistik; Studien zur Germanistik, Skandinavistik und Übersetzungstheorie, Studies in Language, Culture and Society.

e-mail: akatny@wp.pl

Dora Mancheva holds a PhD from the Sofia University and a PhD from the Université de Genève, where she is working at present. She has taught at the Universities of Basel, Bern, Lausanne, Sofia and UNISA in Pretoria. Her research interests have focused on the editing and the study of aljamiado Sephardic printed texts from the Balkans and of manuscripts in Latin characters from the Iberian Peninsula. In recent years she has also been researching the translation and transmission of the names of medicinal plants of America into the European languages.

e-mail: dora.mancheva@unige.ch

Aitor García Moreno, $\mathrm{PhD}$ - currently working as an Investigador Distinguido at the Instituto de Lenguas y Culturas del Mediterráneo y Oriente Próximo (ILC) 
of the Consejo Superior de Investigaciónes Científicas in Madrid and collaborates with the Instituto Universitario Menéndez Pidal (IUMP). He has published several books and more than 40 papers and book chapters in the most internationally prestigious journals and collective volumes. He is mainly devoted to the critical edition of Sephardic texts, paying special attention to their linguistic study in various aspects: phonetics, morphology, syntax and lexicon. Since the last six years, he leads an international team of research to develop a Corpus of the History of Judeo-Spanish (the CORHIJE) and a Historical Dictionary of Judeo-Spanish, both of them available on-line at www.esefardic.es.

e-mail: aitor.garcia@cchs.csic.es

Andrzej Pawelec works as adjunct professor in the Institute of English Studies, Jagiellonian University, Krakow. He teaches Philosophy, Linguistics and Translation Theory. The most important publications: Znaczenie ucieleśnione [Embodied Maning], Krakow 2005; Metafora pojęciowa a tradycja [Conceptual Metaphor and Tradition], Krakow 2006; Prepositional network models: A hermeneutical case study, Krakow 2009. He has recently published articles on Emily Dickinson's poetry in Polish translations and, together with his wife Magdalena Sitarz, articles on the translations of Yitskhok Katsenelson's Dos lid funem oysgehargetn yidishn folk [Song of the Murdered Jewish People].

e-mail: andrzej.pawelec@uj.edu.pl

Jonna Rock (Humboldt-Universität zu Berlin) - PhD Fellow at Ernst Ludwig Ehrlich Scholarship Fund Research at the Institute for South Slavic Languages. Her doctoral thesis describes the challenge for the Sephardic-Jewish community of cultivating Jewish life after the Shoah and the fall of communism in Sarajevo. She graduated Slavonic studies in Berlin, Moscow, St. Petersburg and Uppsala.

e-mail: rockjonn@hu-berlin.de

Julie Scolnik (independent researcher) graduated from the University of California, Santa Barbara, with double majors in Spanish and Hispanic Civilization. She then moved to Madrid where, after teaching English as a second language in Spanish schools, she began researching Judeo-Spanish literature, affiliated with the Consejo Superior de Investigaciónes Científicas. Her main fields of study are the detective novels published in Salonica circa 1905, the product of which is her book Nat Pinkerton: Diez novelas policíacas en lengua sefardí (Barcelona 2014) and the Judeo-Spanish newspaper La America published in New York from 1910-1925. She has published numerous articles on both these topics among which are: The Detective Novel in Ladino: Clues to a 
Little Known Genre (2010) and Advertisements in the Judeo-Spanish Periodical La America: A Reflection of the Sephardic Society of New York (2014) as well as the study of the book published in the journal La Anerica, Libro para embeźar las linguas ingleśa y yudiš (2014). In 2015 she returned to the country of her birth and now lives in San Francisco where she continues with her research.

e-mail: jscolnik@hotmail.com

Magdalena Sitarz works as adjunct professor in the Institute of Germanic Studies, Jagiellonian University, Krakow. She specializes in modern German Literature as well as in Yiddish Studies. The most important publications: $Z$ dziejów jidysz - jednego z języków żydowskich. Wprowadzenie do nauki języka dla szkół wyższych [Yiddish - one of the Jewish Languages - and Its History. An Introductory Course of Yiddish for Students], Krakow 1992; Yiddish and Polish Proverbs - Linguistic and Cultural Contacts, Krakow 2000; Literature as a Medium for Memory. The Universe of Sholem Asch's Novels, Frankfurt am Main 2013.

e-mail: magdalena.sitarz@uj.edu.pl

Izabela Olszewska, $\mathrm{PhD}$ - an assistant professor at the Institute of German Philology at the University in Gdańsk (Poland). Her academic interests involve the language and culture of Ashkenazi Jews, Holocaust, media linguistics and Culture of Remembrance. She published i.a. Zur Übersetzung von Judaica in ausgewählten Werken der jiddischen Literatur (2011).

e-mail: i.olszewska@ug.edu.pl

Aleksandra Twardowska - an assistant professor at the Department of Balkan Studies at the Nicolaus Copernicus University in Torun (Poland). Her academic interests involve the language, culture and history of Balkan Jews, Jewish and Slavic anthroponomy and Balkan languages. She has written several papers on the Balkan Sephardi Jewry.

She co-edits the series Getting Know the Balkans for young scholars. She is also a member of the Polish Association for Jewish Studies and the Polish Commission of Balkan Culture and History.

e-mail: atwardowska@umk.pl

Agnieszka August-Zarębska, $\mathrm{PhD}$ - graduated in Spanish studies and is specialist in comparative Spanish and Polish poetry as well as in Judeo-Spanish literature and culture. She is an assistant professor in the Department of Jewish Studies of the University of Wrocław where she teaches Ladino language and 
Sephardic culture. She also collaborates with the Department of Spanish Studies of the same University. She wrote her PhD thesis on Czesław Miłosz's and Jorge Guillén's poetry and papers on Judeo-Spanish contemporary literature.

e-mail: agnieszka.august-zarebska@uwr.edu.pl

Tomasz Zarębski - an associate professor at the University of Lower Silesia (Wrocław). He deals with contemporary philosophy, especially philosophy of language, epistemology, and theory of argumentation. He is the author of two monographs: Od paradygmatu do kosmopolis. Filozofia Stephena E. Toulmina [From Paradigm to Kosmopolis. The Philosophy of Stephen E. Toulmin], 2005, and Neopragmatyzm Roberta B. Brandoma [The Neopragmatism of Robert B. Brandom], 2013. He is also a translator of several philosophical texts into Polish.

e-mail: tomasz.zarebski@dsw.edu.pl 